\author{
UNIVERSIDADE DE SÃO PAULO \\ FACULDADE DE FILOSOFIA, LETRAS E CIÊNCIAS HUMANAS \\ DEPARTAMENTO DE LETRAS CLÁSSICAS E VERNÁCULAS \\ ESTUDOS COMPARADOS DE LITERATURAS DE LÍNGUA PORTUGUESA
}

Maged Talaat Mohamed Ahmed El Gebaly

Mobilidades culturais e alteridades em Relato de um certo oriente e sua pré-tradução árabe

São Paulo 


\author{
UNIVERSIDADE DE SÃO PAULO \\ FACULDADE DE FILOSOFIA, LETRAS E CIÊNCIAS HUMANAS \\ DEPARTAMENTO DE LETRAS CLÁSSICAS E VERNÁCULAS \\ ESTUDOS COMPARADOS DE LITERATURAS DE LÍNGUA PORTUGUESA
}

\title{
Mobilidades culturais e alteridades em Relato de um certo oriente e sua pré-tradução árabe
}

\author{
Tese apresentada como exigência para a \\ conclusão do Doutorado na área de Estudos \\ Comparados de Literaturas de Língua \\ Portuguesa do Departamento de Letras \\ Clássicas e Vernáculas da Faculdade de \\ Filosofia, Letras e Ciências Humanas da \\ Universidade de São Paulo.
}

Orientador: Prof. Dr. Benjamin Abdala Junior

Co-orientador: Prof. Dr. Mamede Mustafa Jarouche (DLO)

\section{São Paulo}


Autorizo a reprodução e divulgação total ou parcial deste trabalho, por qualquer meio convencional ou eletrônico, para fins de estudo e pesquisa, desde que citada a fonte.

\author{
Catalogação na Publicação \\ Serviço de Biblioteca e Documentação
}

Faculdade de Filosofia, Letras e Ciências Humanas da Universidade de São Paulo

El GEBALY, Maged Talaat Mohamed Ahmed.

Mobilidades culturais e alteridades em Relato de um certo oriente e sua prétradução árabe/ Maged El Gebaly - São Paulo, 2012..

Orientador: Prof. Dr. Benjamin Abdala Junior

Co-orientador: Prof. Dr. Mamede Jarouche Moustafa (DLO)

Tese (Doutorado) - Universidade de São Paulo, Faculdade de Filosofia, Letras e Ciências Humanas. Departamento de Letras Clássicas e Vernáculas. Programa de Pós-graduação em Estudos Comparados de Literaturas de Língua Portuguesa.

1. Mobilidades. 2. Alteridades. 3.Narrativa. 4. Memória. 5. Tradução. 


\section{Folha de Aprovação}

El GEBALY, Maged Talaat Mohamed Ahmed.

Mobilidades culturais e alteridades em Relato de um certo oriente e sua pré-tradução árabe

Aprovado em

\section{Banca Examinadora}

Prof(a). Dr(a).

Julgamento:

$\operatorname{Prof}(a) . \operatorname{Dr}(a)$.

Julgamento:

Prof(a). Dr(a).

Julgamento:

Prof(a). Dr(a).

Julgamento:

Prof(a). Dr(a).

Julgamento:
Instituição:

Assinatura:

Instituição:

Assinatura:

Instituição:

Assinatura:

Instituição:

Assinatura:

Instituição:

Assinatura: 


\section{Sumário}

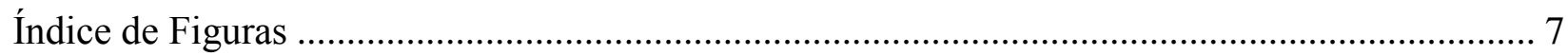

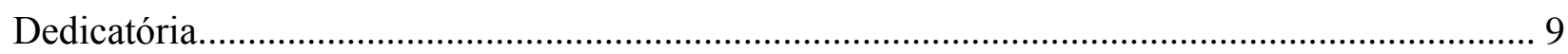

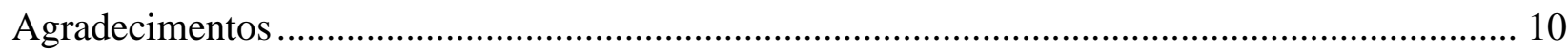

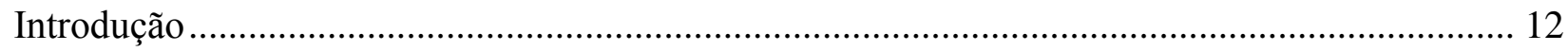

Capítulo I: Contexto geral da imigração árabe no Brasil ............................................................. 17

1.1. Primeiros contatos no período colonial ........................................................................ 17

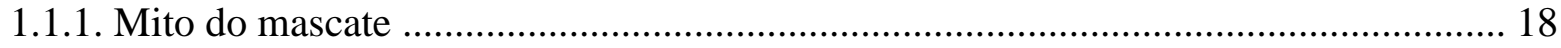

1.2. Fases da imigração libanesa para o Brasil .............................................................................. 19

1.2.1. Período do domínio otomano (1850-1920) ................................................................... 19

1.2.1.1. Dom Pedro no mundo árabe .................................................................................. 20

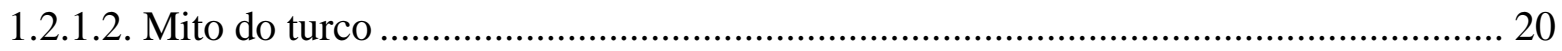

1.2.2. Período de entre-guerras (1920-1940) ..................................................................... 21

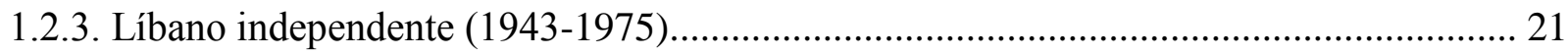

1.2.4. Guerra no Líbano (1975-2000).................................................................................. 21

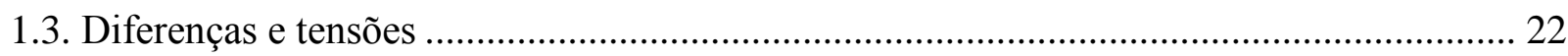

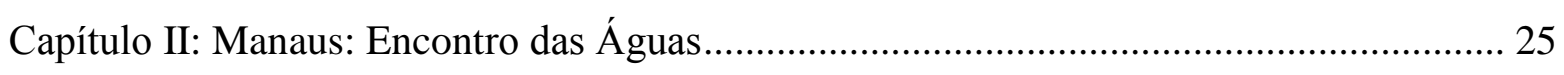

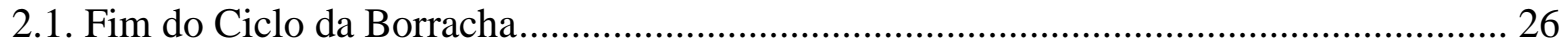

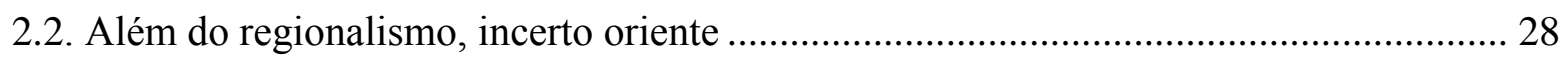

Capítulo III: Memória cultural e autoficção ………………………………………….......... 36

3.1. Memória familiar e sombras da infância .............................................................................. 41

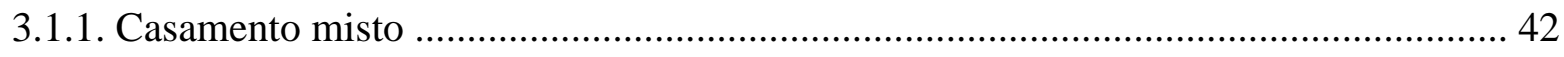

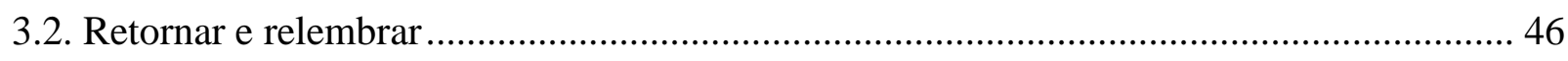

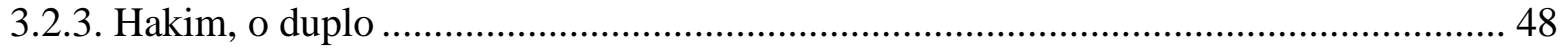

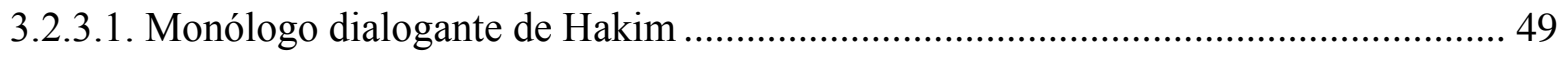

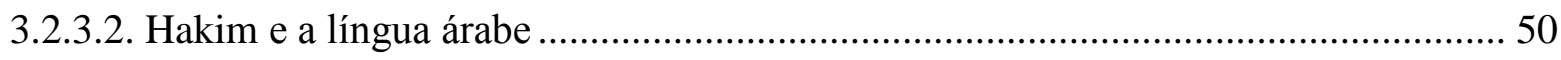

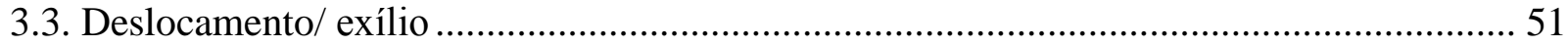

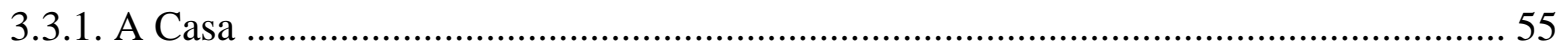

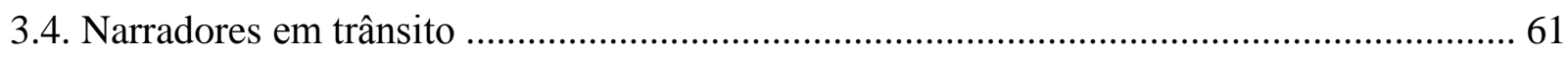

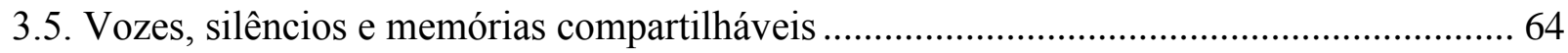


3.5.1. Vozes femininas 65

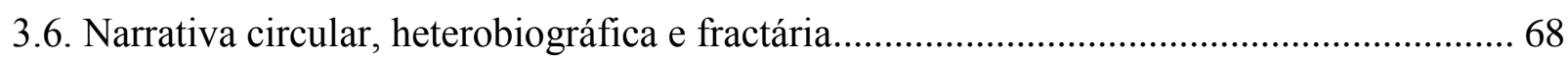

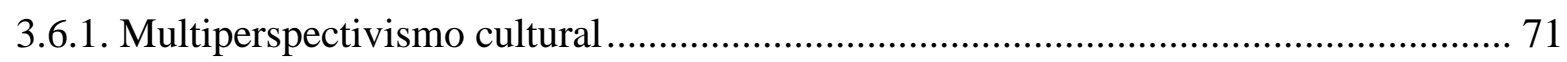

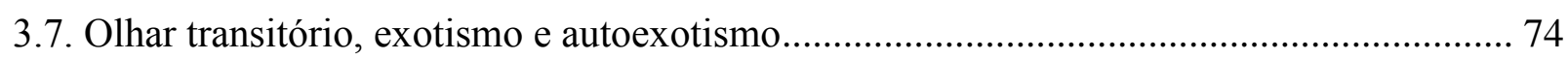

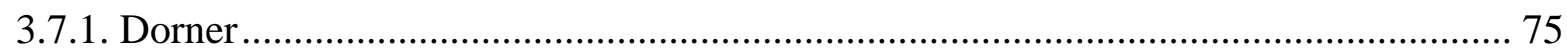

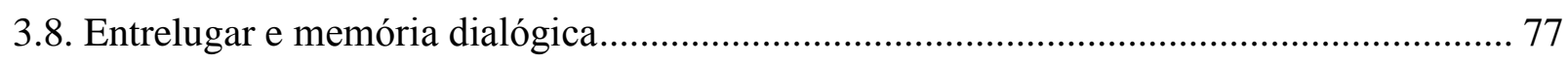

Capítulo IV: Pré-tradução árabe de Relato de um certo oriente ……………………...................... 84

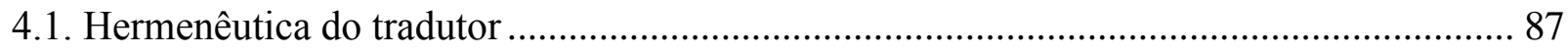

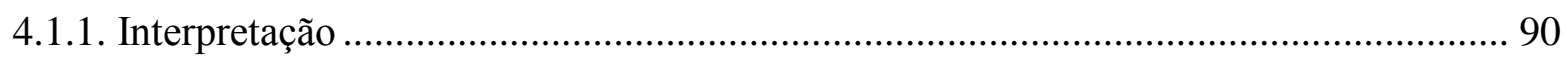

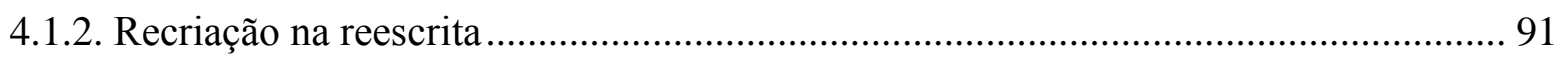

4.2. Conarração do tradutor literário ..................................................................................... 93

4.3. Identificação da hermenêutica do tradutor .................................................................... 95

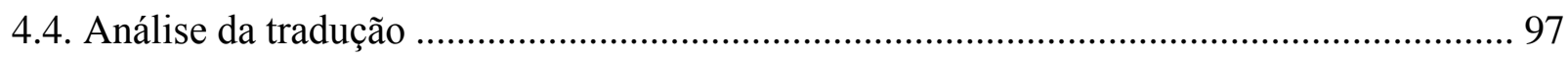

4.4.1. Problemas e técnicas de tradução ………………………………………………...... 98

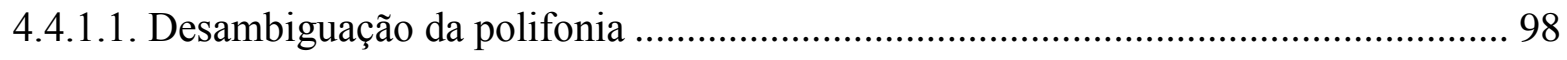

4.4.1.2. Identificação e codificação de vozes misturadas ...................................................... 99

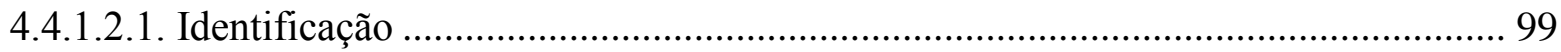

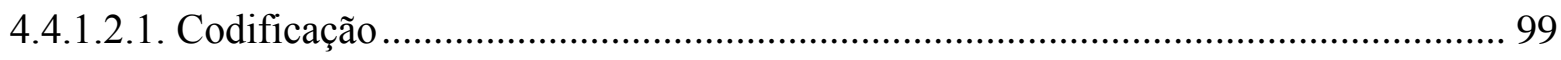

4.4.1.3. Decifração dos modos verbais das vozes narrativas.............................................. 100

4.4.1.4. Especificação semântica ..................................................................................... 100

4.4.1.5. Tradução das referências culturais ........................................................................ 100

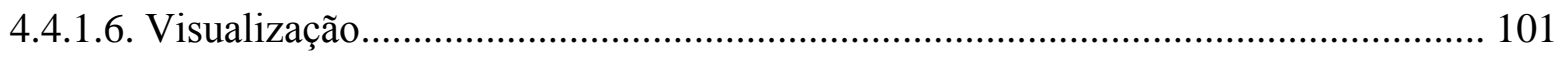

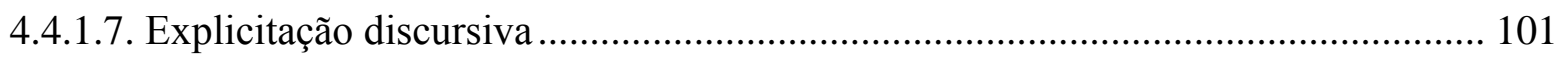

4.4.1.8. Transliteração ................................................................................................. 102

4.4.1.8.1. Entre a tradução literal de uma marca cultural social e o seu empréstimo.......... 103

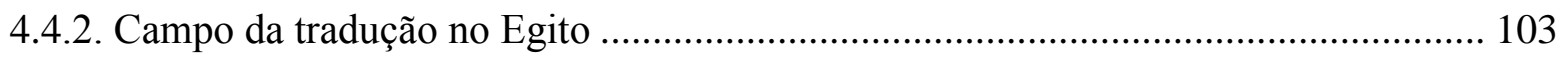

4.4.2.1. Tradutores da literatura latino-americana no Egito ................................................. 105

4.4.2.2. Tradução das narrativas modernas de memória no Egito......................................... 106

4.4.2.3. Agentes da tradução latino-americana no Egito …………………………………..... 107

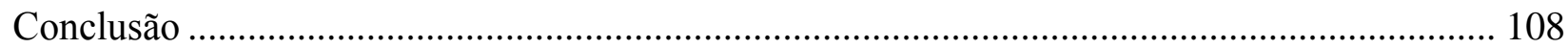

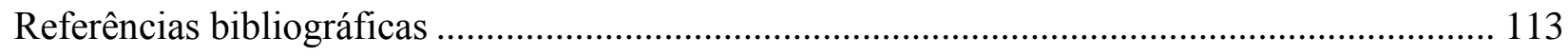


Anexo 1: Entrevista com Milton Hatoum: "Não há tantos tradutores de literaturas de língua portuguesa"

Anexo 2: Resumos do minicurso "DO ROMANCE À NARRATIVA BREVE” Ministrado pelo Milton Hatoum em Casa do Saber (Para ser aproveitado neste capítulo)

Professor: Milton Hatoum - Aula 01 - 25/08/2009 ..................................................... 142

Professor: Milton Hatoum- Aula 02 a 26/08/2009 ......................................................... 144

Anexo 3: Mostra da tradução árabe da metade de Relato de um certo oriente (Capítulos 1, 2, 3,

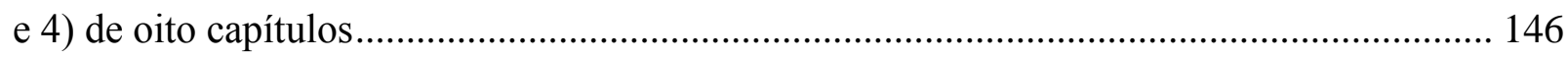

Anexo 4: Análise de fenômenos de tradução ............................................................... 188

Anexo 5: Narrativas que jogam com o imaginário da imigração árabe no Brasil................. 204 


\section{Índice de Figuras}

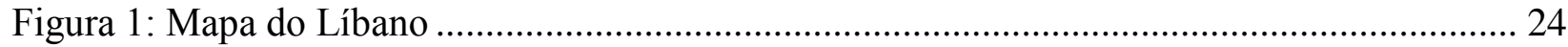

Figura 2: Loja de temperos no centro de Manaus (Maged El Gebaly, Manaus, 16/05/2012)..... 27

Figura 3: Mapa do Brasil (Fonte: IBGE, 1999)................................................................... 28

Figura 4: Gimnasio Amazonense Pedro (Maged El Gebaly, Manaus, 16/05/2012). .................... 42

Figura 5: Estrutura genealógica da família-núcleo do Relato de um certo oriente (REZENDE,

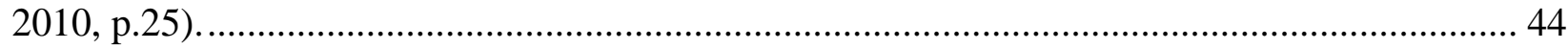

Figura 6: Multiverso de Milton Hatoum, Maged El Gebaly, 2012 . .......................................... 51

Figura 7: Rio Negro (Maged El Gebaly, Manaus 16/05/2012) .................................................. 53

Figura 8: Igreja Nossa Senhora dos Remédios (Maged El Gebaly, Manaus, 16/05/2012) ........... 53

Figura 9: O Porto de Manaus (Maged El Gebaly, Manaus, 16/05/2012) ...................................... 54

Figura 10: Alfândega de Manaus (Maged El Gebaly, Manaus, 16/05/2012) ................................ 54

Figura 11: Pagode no Palácio do Centro Cultural do Rio Negro (Maged El Gebaly, Manaus,

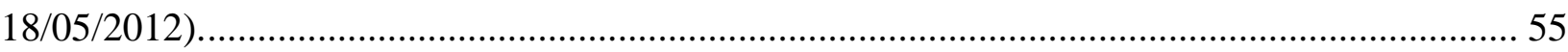

Figura 12: Pagode no Palácio do Centro Cultural do Rio Negro (Maged El Gebaly, Manaus,

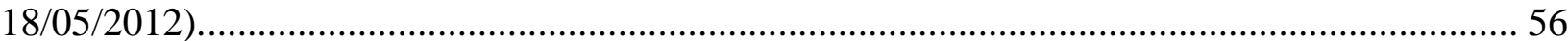

Figura 13: Uma claraboia no Palácio do Centro Cultural do Rio Negro (Maged El Gebaly,

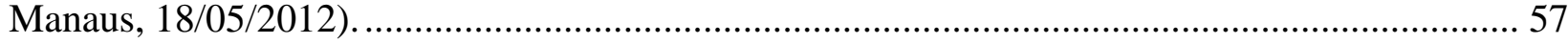

Figura 14: Fonte no Palácio do Centro Cultural do Rio Negro (Maged El Gebaly, Manaus.

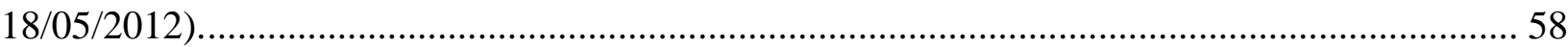

Figura 15: Mapa do deslocamento no Relato de um certo oriente (DE ANDRADE, 2007)........ 59 Figura 16: Representações de identidades diferentes na literaria brasileira (Maged El Gebaly, 2012) 64

Figura 17: Estrutura completa dos capítulos do Relato (REZENDE, 2010, p.73) ........................ 70 Figura 18: Pintura do teto no Salão Nobre do Teatro Amazonas (Maged El Gebaly, Manaus,

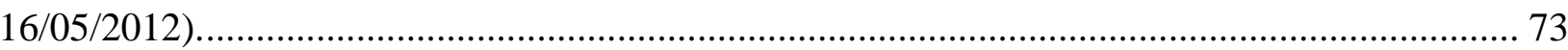

Figura 19: Do "não lugar" ao "entre-lugar" (Maged El Gebaly, 2012)......................................... 77

Figura 20: Evolução dos estudos da tradução: dos estudos formais da tradução até os estudos

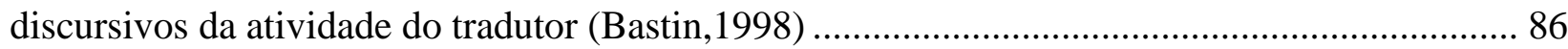

Figura 21: Três momentos do processo da tradução (Maged El Gebaly, 2011)........................... 89 
Figura 22: Movimento hermenêutico da tradução de George Steiner (1975), gráfico por Maged El

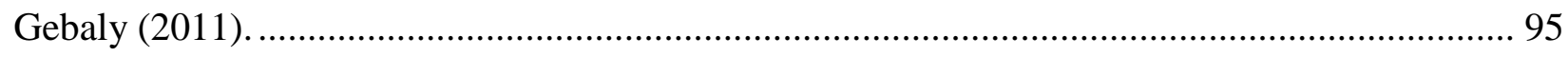

Figura 23: Identificação do movimento hermenêutico do tradutor (Maged El Gebaly, 2011) ..... 96 


\section{Dedicatória}

Às professoras e aos professores que contribuem na construção de um mundo melhor. Às amigas e aos amigos que aguardam a conclusão desta tese.

A todos aqueles descendentes de imigrantes.

A minha família e amigos no Egito que acompanharam essa luta pela conclusão deste doutoramento em Língua Portuguesa e suas letras.

À Colômbia que me apoiou no estudo da língua portuguesa.

A Manaus e seu povo... 


\section{Agradecimentos}

Ao Prof. Dr. Benjamin Abdala Júnior, pelo apoio e orientação, que por muitos anos de convivência, muito me ensinou, contribindo para meu crescimento pessoal e intelectual.

Ao Prof. Dr. Mamede Mustafa Jarouche e Prof ${ }^{a}$ Dr $^{\mathrm{a}}$. Safa Jubran, pelas leituras, pelas observações, e pela revisão da parte árabe do texto.

Ao Milton Hatoum, pelas variadas entrevistas e conselhos.

Ao Programa de Estudos Comparados de Literaturas de Língua Portuguesa da FFLCH da USP.

À CAPES (PEC- PG), pela bolsa concedida.

Ao Prof. Dr. Allison Leão, pela visita a Manaus.

Ao Prof.Khalid Tailche, pela revisão da padronização do texto.

À Samira Ahmad Orra, pelas leituras e ricas discussões sobre os descendentes de libaneses no Brasil.

A Paola Giraldo Herrera e a André Oda, pelas valiosas discussões.

A todos os funcionários amigos na FFLCH que me apoiaram muito. 


\section{Resumo}

Esta tese tem como objetivo discutir as variadas manifestações de mobilidades culturais e suas consequentes relações de alteridades no romance Relato de um certo oriente de Milton Hatoum, partindo do suposto de que a alteridade é parte constituinte da subjetividade e da relação humana de diferença e identidade com o Outro; e, ao mesmo tempo, analisar o processo intercultural da pré-tradução para a língua árabe de quatro capítulos do Relato de um certo oriente. Nesse sentido, este trabalho está focado em dois lócus das mobilidades culturais das alteridades: a narrativa de memória da imigração e a tradução literária.

Palavras chaves: mobilidades, alteridades, narrativa, memória, tradução. 


\begin{abstract}
This thesis aims to discuss the various manifestations of cultural mobilities and its consequent relations of alterities in the novel Tale of Certain Orient of Milton Hatoum, assuming that otherness is a constituent part of human subjectivity and its relationship of difference and identity with the Other; and at the same time we intend also to analyze the processo of intercultural pretranslation into Arabic of four chapters of the novel. In this sense, this work is focused on two locals of cultural mobilities of alterities: the narrative memory of immigration and literary translation.
\end{abstract}

Keywords: mobilities, alterities, narrative, memory, translation. 


\section{Introdução}

Começamos esta pesquisa buscando uma integração cultural entre árabes e brasileiros por meio do estudo das narrativas literárias da imigração, seus mitos e sua tradução cultural. Seguindo a Souza Santos, entendemos a tradução como "um trabalho argumentativo de imaginação epistemológica e de imaginação democrática presente nas reflexões e preocupações de todas aquelas perspectivas, movimentos e práticas que propõe o objetivo de construir novas e plurais formas de emancipação social" (SANTOS, 2005: 168). Movido por esse interesse acadêmico pelos temas da construção das relações humanas de diferença e de identidade na obra de Milton Hatoum, fomos lendo as suas obras, o que nos levou, depois, a conhecer desde uma ótica cultural afetiva, sua terra Manaus.

Assim como Jacques Le Goff, podemos abordar nesta tese duas vozes à margem da história tradicional (da imigração e da tradução), como duas formas de mobilidade cultural que caracterizam nossa era. Seguindo Sorokin (1964) entendemos mobilidade cultural como o deslocamento de significados, normas, valores e vínculos. Bernd (2010) detecta cinco tipos de mobilidades culturais: as desviantes como a liquidez, as espaciais do imaginário das metrópoles como as circulações urbanas, as memoriais ou intersubjetivas como a autoficção e a memória, as migratórias transculturais como a migração e o deslocamento, e as transnacionais como a tradução e a mobilidade linguística.

A realidade da imigração e sua descendência só pode ser traduzida internamente por meio da imaginação. Mas também, o discurso da ficção consegue atravessar as fronteiras linguísticas nacionais para entrar em outras culturas por meio da tradução externa. No processo das mobilidades culturais dialogam alteridades internas e externas entre si, como parte constituinte da subjetividade e da relação humana de diferença e identidade com o Outro (LEVINAS, 1988).

Uma das questões levantadas pelos críticos brasileiros é a representação das realidades culturais no Relato de um certo oriente, que tem uma "simbiose" de dois mundos superpostos (de Manaus e do Líbano). Na narrativa, Hatoum procurou criar um discurso liberto do olhar exótico sobre o Amazonas e sobre os árabes. Contra esse olhar, ele lança relatos polifônicos de "um certo oriente", com diversidade de vozes narrativas e pontos de vista. O progresso na cidade de 
Manaus significou, em alguma medida, a fragmentação do sujeito. Hatoum cria uma Manaus como espaço literário de alteridades e cenas, fragmentos de narrativas heterogêneas e fantasmas das memórias vivenciadas pelo escritor e representadas pelas vozes dos seus narradores (BACHELARD, 2008).

Ao longo de diversas passagens históricas do Brasil (Colônia, Império e República), foram discutidas as conceituações e as ideias de entre-lugares, como zona intermediária entre dois espaços em contato, imagens de espaços vivenciados em misturas culturais, de hibridismos, de mestiçagens, de sincretismos religiosos e da miscigenação étnica.

O Brasil é considerado um país que atraía os imigrantes árabes para se livrarem de sofrimento de ordem econômica, social e política e para compartilharem com outros imigrantes a construção de novas identidades. A presença árabe é claramente visível nas várias esferas da vida, nas províncias e nas cidades grandes, onde os imigrantes árabes e seus descendentes fazem parte do tecido cultural, social e político do Brasil.

Milton Hatoum, filho de imigrantes árabes, viajou por várias cidades e publicou sua obra em 1989, que narra a partir do Natal de 1954. A respeito da relação entre a publicação do Relato de Hatoum e Raduan Nassar, Susana Moreira (2012) conta:

Quando terminou de escrever (o Relato), não pensou logo em publicar. Foram precisos dois anos e a insistência de amigos críticos literários e escritores - entre eles Raduan Nassar, autor de Lavoura Arcaica, um dos mais marcantes romances brasileiros, também sobre uma família libanesa.

Foi Maria Emília Bender que editou o Relato e apresentou a obra para Luis Schwarcz, dono da Companhia das Letras. Hatoum ganhou a bolsa da VITAE para se dedicar ao seu segundo romance, Dois irmãos. Assim que, o escritor foi consolidando sua posição no campo literário como vemos na tabela abaixo: 
Tabela 1: Produções de Milton Hatoum e consolidação da sua posição, adaptado de AVELINO, 2010.

\begin{tabular}{|c|c|c|c|c|}
\hline Tipo de produção & $\begin{array}{l}\text { Lugar de } \\
\text { realização }\end{array}$ & Data & Edição/Publicação & Apreciação \\
\hline Redação escolar & Manaus & 1967 & $\begin{array}{l}\text { Jornal estudantil - } \\
\text { Elemento } 106\end{array}$ & Amigos/Familiares \\
\hline Poesia & São Paulo & 1979 & Ed. Diadorim & $\begin{array}{l}\text { Crítica } \\
\text { Literária/Intelectuais/público } \\
\text { restrito. }\end{array}$ \\
\hline $\begin{array}{l}\text { Relato de um certo } \\
\text { oriente }\end{array}$ & São Paulo & 1989 & Ed. Cia das Letras & $\begin{array}{l}\text { Crítica } \\
\text { literária/escritores/editores/ } \\
\text { público difuso. Prêmio Jabut } \\
\text { (1990) }\end{array}$ \\
\hline Dois irmãos & São Paulo & 2000 & Ed. Cia das Letras & Prêmio Jabuti (2001) \\
\hline Cinzas do Norte & São Paulo & 2005 & Ed. Cia das Letras & Prêmio Jabuti (2006) \\
\hline Órfãos do Eldorado & São Paulo & 2008 & Ed. Cia das Letras & Prêmio Jabuti (2009) \\
\hline A cidade ilhada & São Paulo & 2009 & Ed. Cia das Letras & Prêmio Jabuti (2010) \\
\hline
\end{tabular}

Neste estudo analisamos o Relato de um certo oriente como uma tendência contemporânea à produção de uma narrativa memorialística íntima, chamada autoficção, termo cunhado em 1977 por Serge Doubrovsky para referir-se a uma forma de inserção da história entre autobiografias de fatos reais tratados de modo ficcional imaginário, onde o eu se divide em vários personagens fictícios. O escritor prepara um terreno de ambiguidade em que o eu é ao mesmo tempo sujeito e objeto da narração (OUELLETTE- MICHALSKA, 2007). Como nos contou Hatoum: "O Relato de um certo oriente é como os franceses chamam "um relato de memória", de tom evocativo. Há uma frase de um personagem no Relato que diz 'a vida começa verdadeiramente com a memória' ”. (HATOUM, 2010). 
Nessa narrativa literária da memória involuntária, encontramos uma forma de rebeldia à historiografia serial tradicional, que reduzia a relação do ser humano com o passado a um processo linear e exato. O isolamento cultural imposto pelos sistemas positivistas fechados, apoiados por forças conservadoras, produz frustração no projeto da modernidade ${ }^{1}$. Talvez, como resposta a esta crise, a literatura contemporânea se construa, em muitas de suas realizações, como um espaço de resistência enraízda e mediação desenraízada, colocando em evidência a reinvenção da identidade narrativa (FANTINI, 2004). Cada trauma é tolerável se nós o narramos como história. Os vestígios e os fantasmas da memória coletiva são resgatáveis (RICOEUR, 2007).

Os estudos transculturais comparados e suas traduções são campos de pesquisa multidisciplinares, interdisciplinares e transdisciplinares. Esses estudos pesquisam os processos de desculturação, reculturação, neoculturação, que geram diferenciação de identidades. Vão além do paradigma das diversidades culturais do multiculturalismo. Reconhecem no outro suas diferenças como sua humanidade, na direção de um processo intersubjetivo, aberto, reflexivo, ético, dialógico, valorativo, criativo, ousado e complexo. Seremos tanto mais transculturais, quanto mais nos colocarmos dos pontos de vista das outras culturas. Dos objetos de pesquisa dos estudos transculturais existem: a memória cultural, o imaginário, as fronteiras, as identidades, as diferenças e as alteridades. Este estudo tece o discurso da literatura e outros saberes como a história, a antropologia, a psicanálise e outras linguagens como a fotografia para visualizar nossas ideias (FERNANDO ORTIZ apud RAMA, 1982).

O Relato se coloca dentro de um dos lócus da diferença que é a narrativa de memória, de uma família libanesa e manauara ao mesmo tempo. O processo de tradução árabe do Relato implica outro lócus da diferença, na medida em que é um deslocamento e uma atualização da narrativa em outro contexto literário diferente: o egípcio. A tradução árabe completa de Em busca do tempo perdido de Marcel Proust só se traduz por Gamal Shahid e se publica no Cairo em

\footnotetext{
${ }^{1}$ Entendemos por modernidade aquela visão de mundo relacionada ao projeto empreendido a partir da transição teórica operada por Descartes, com a ruptura com a tradição herdada - o pensamento medieval dominado pela Escolástica - e o estabelecimento da autonomia da razão. O projeto moderno consolida-se com a Revolução Industrial. O termo está ligado também a uma série de transformações que ocorreram no decorrer do século XX em especial na segunda metade do século - e provocaram alterações em vários níveis da vida humana (GIDDENS, 1990, apud; FIGUEIREDO, 2010).
} 
2005. Este tipo de narrativa no campo cultural egípcio vem desenvolvendo-se de duas fontes principais: as narrativas autobiográficas clássicas da era de independência em relação a Gran Bretanha e as narrativas mais recentes dos estudiosos árabes que tiveram contato com a literatura francesa e conseguiram ter acesso direto à tradição literária de Marcel Proust (SHAHID, 2011). Aqui cabe ressaltar a distinção, assinalada pela crítica Vera Mâquea (2007), entre a construção da memória em Proust e a mesma em Milton Hatoum: "Em quanto Proust queria voltar a sentir o gosto das coisas vividas por meio da procura do tempo perdido... em Hatoum é uma memória pronunciada do devir, o seja, visitar o passado com mesmo estranhamento com que se visita o futuro" p.252.

Este estudo propõe como objetivos: por um lado, explorar as diferentes manifestações de mobilidades culturais e suas consequentes relações de alteridades no Relato de um certo oriente de Milton Hatoum ${ }^{2}$, partindo do suposto de que a alteridade é parte constituinte da subjetividade e da relação humana de diferença e identidade com o Outro; e por outro lado, analisar o processo intercultural da pré-tradução árabe de quatro capítulos do Relato de um certo oriente, como uma primeira fase da cadeia comunicativa da tradução ( autor-obra-editora-tradutor-público) (HURTADO ALBIR, 2001). Nesse sentido, nossa pesqusia está focada em dois lócus das mobilidades culturais das alteridades: a narrativa de memória da imigração, e a tradução literária.

\footnotetext{
${ }^{2}$ Os trabalhos de Milton Hatoum encontram-se no seu site pessoal www.miltonhatoum.com.br, lançado no mês de setembro de 2010.
} 


\section{Capítulo I: Contexto geral da imigração árabe no Brasil}

O Mundo Árabe se parece com o Brasil... Talvez a gente deva isso a um passado muito distante, ibérico (Milton Hatoum, 2010).

A integração do elemento árabe no Brasil processou-se de maneiras diferentes nas diversas regiões do país. Isto se deu em função do meio social, das ocupações dos imigrantes e de seu número. A origem do imigrante árabe no Brasil varia em função da época e da sua localização geográfica. A fixação em diferentes regiões compreende fatores locais e externos, psicológicos e práticos. Também a realidade da diáspora árabe no Brasil varia conforme a origem dos imigrantes, religião e etnia e os motivos da migração e classe social e consciência política, etc. A primeira geração de imigrantes árabes sobreviveu com atividades econômicas populares como o comércio e restaurantes, enquanto a segunda e terceira gerações começaram a fazer parte da classe média profissional constituída por professores, médicos, advogados, engenheiros...etc.

\subsection{Primeiros contatos no período colonial}

Há indícios no nordeste brasileiro, como as fisionomias, a gastronomia, a arquitetura urbana e os costumes, que fazem referência à cultura moura que viveu na Andaluzia por mais de 800 anos. Benjamin Abdala Junior (2012) observou:

Os primeiros colonizadores da América Latina vieram da região que os árabes chamaram de Al-Ândalus. Algarve provém de Al-Gharb alÂndalus (Andaluzia Ocidental), que abrangia o atual Algarve e o baixo Alentejo. A maior parte da população popular de Lisboa, na época dos Descobrimentos, some-se a essas constatações, era de origem moura. Eram regiões culturalmente híbridas, para onde confluíram muitas culturas da bacia cultural mediterrânea.

Com relação à origem árabe dos nomes das primeiras cidades do nordeste brasileiro, $\mathrm{o}$ filólogo Assad Zaidan (2010) assinala que Recife veio do árabe "رصيف", que significa cais do porto e agrega: 
Segundo os historiadores Jamil e Jorge Safady (1950), há um manuscrito na Biblioteca Pública da capital russa Moscu que consta que o marinheiro árabe, Ibn Majed que tripulou em 1500 a esquadra de Pedro Álvares Cabral, ao avisar o literal baiano gritou "Bahia", "بعية", [o que quer dizer em árabe bonita] e o que deu nome à região.

\subsubsection{Mito do mascate}

A primeira geração de imigrantes árabes sobreviveu por meio de atividades econômicas populares como o comércio. Fizeram os percursos da "mascateação", ou seja, ser masqate, fenômeno herdado das tradições mediterrâneas. Esta mascateação é que dá o sentido da integração cultural por via fluvial. O Rio Nilo une o Egito e os rios do Brasil com seus mascates unem suas extensas terras com narrativas desta mobilidade que permite o conhecimento mútuo entre um brasileiro e outro. A palavra "mascate" é de origem árabe. De 1507 a 1658, os portugueses conquistaram a cidade de Mascate no Golfo Árabe (atual capital de Omã). Como a cidade era um ponto comercial de venda, compra e troca de toda espécie de mercadoria, os comerciantes portugueses que regressavam a Portugal de lá, trazendo seus produtos, eram chamados de "mascates", um apodo ao comércio oriental (KHATLAB, 2002). No Brasil, a atividade de mascate foi seguida por muitos grupos de imigrantes como meio ocupacional. Os primeiros mascates dos tempos coloniais até quase o fim do séc. XIX foram os portugueses, mais tarde substituídos pelos italianos, originários em sua maioria da Calábria, que mascateavam produtos de armarinhos e roupas feitas (KNOWLTON, 1955). O mascate "bandeirante da modernidade brasileira", personagem descendente das tradições mediterrâneas, viaja pelos rios e mares trocando artigos, produtos, mercadorias e também saberes e conhecimentos. A mascateação deu sentido de integração cultural entre os centros urbanos e as áreas interioranas e rurais. A mesma palavra manifesta mobilidade cultural entre as duas línguas: foi derivada do árabe (مسقط) e voltou ao árabe, mas aportuguesada (ماسكاته). A imigração libanesa para o Brasil iniciou-se oficialmente após a visita de D. Pedro II ao Líbano. Gattaz (2005) organiza a história dessa imigração nas seguintes fases: 


\subsection{Fases da imigração libanesa para o Brasil $^{3}$}

\subsubsection{Período do domínio otomano (1850-1920)}

Pelas necessidades econômicas durante o Império Turco-Otomano (15161918), chegaram ao Brasil famílias rurais do Líbano, Síria e de todo o mundo árabe com o propósito de estabelecer-se definitivamente.

Sobre os primeiros árabes no Brasil, Roberto Khatlab ${ }^{4}$ (2010) conta:

O gramático Manuel Said Ali, nascido em Petrópolis, no Rio de janeiro em 1861, era filho de Said Ali, árabe que faleceu dois anos depois do nascimento desse filho. Uma prova contundente de que já habitava o Brasil antes de 1861. Recentemente foi publicada a tradução do livro 'Deleite do estrangeiro em tudo o que é espantoso e maravilhoso: estudo de um relato de viagem bagdali', escrito pelo imã Abdurrahmán Al-Baghdádi, árabe nascido em Bagdá, que viveu no Brasil de 1865 a 1868.

Sobre esse período, consultamos o arquivo virtual da Família Doualib onde encontramos que:

As primeiras datas da vinda dos libaneses podem ser fixadas antes de 1885 . O período imigratório árabe no Brasil até fins de 1900 é considerado a primeira fase. É o período de aventuras onde a América era tema lendário para os povos árabes, sem autonomia própria, e dependentes do Império Otomano. Os imigrantes adotavam novos nomes em função de sua atividade no Brasil. Isto está relacionado com a dificuldade de pronúncia de letras guturais e aspiradas. Há nomes adotados por analogia ou por tradução que eles mesmos criaram.

Pelas necessidades econômicas durante o Império Túrco- Otomano (1516-1918), chegaram ao Brasil famílias rurais do Líbano, Síria e todo o mundo árabe. A maior parte dos primeiros imigrantes vem de sociedades rurais, de aldeias, províncias ou cidades pequenas para metrópoles industrializadas no Brasil (GATTAZ, 2005).

3 GATTAZ, André. Do Líbano ao Brasil: história oral dos imigrantes. São Paulo: Gandalf, 2005.

${ }^{4}$ Khatlab, Roberto. "Quando os árabes chegaram ao Brasil”, São Paulo: crônica publicada 08/04/2010. Disponível em: $<$ http://www.icarabe.org/artigos/quando-os-arabes-chegaram-ao-brasil $>$. Acesso: 23/07/2012. 


\subsubsection{Dom Pedro no mundo árabe}

Respeito à visita de D.Pedro II nesse periodo, Khatlab (2000) conta:

O Imperador do Brasil na época, D. Pedro II (1825-1891), visitou o Egito em 1871, e em 1876 visitou o Líbano, a Síria e a Palestina (...). Em sua estada no Líbano, de 11 a 15 de novembro de 1876, o Imperador escreveu ao seu amigo, o diplomata francês Joseph Gobineau, que ficara em Atenas, Grécia: "Tudo vai bem... A partir de hoje começa um mundo novo. O Líbano ergue-se diante de mim com seus cimos nevados, seu aspecto severo, como convém a essa sentinela da Terra Santa...” (Arquivo Histórico de Estrasburgo - França).

\subsubsection{Mito do turco}

Jorge Amado narra na Descoberta da América pelos turcos: "Os primeiros a chegar do Oriente Médio traziam papéis do Império Otomano, motivo porque até os dias atuais são rotulados de turcos". O mito fundador do mascate tem muita importância e grande valor para as comunidades árabes espalhadas por todo Brasil. Os primeiros imigrantes árabes exerciam atividades comerciais e grande parte iniciou seus negócios trabalhando como vendedores ambulantes ou mascates. Nesse contexto surge a figura do "turco", porque a imigração árabe naquele momento chegava ao Brasil com passaportes turcos do Império Otomano, atual Turquia (PETERS, 2006).

A representação da imigração árabe do século XIX foi estigmatizada com a da imagem folclórica do turco como figura mesquinha, dono de comércio qualquer na esquina. Esta situação muda na literatura brasileira contemporânea com a participação ativa de escritores árabes, descendentes e amigos da sua cultura. Carreira (2008) assinala:

As ondas migratórias no Brasil foram seguidas da construção de estereótipos, verificáveis, por exemplo, em obras da literatura naturalista brasileira. Os rótulos que acompanharam os imigrantes de diversas nacionalidades, como "turco", no caso dos imigrantes de origem árabe, funcionavam sob a ótica da exclusão. A literatura brasileira contemporânea, no entanto, lança um olhar diferenciado sobre a imigração, possibilitando uma releitura do processo de inserção do imigrante na sociedade. Obras de autores como Milton Hatoum e Raduan Nassar, entre outros, permitem uma reflexão sobre os conflitos da condição de estrangeiro, imigrante, e descendente por uma via que tanto escapa à visão estereotipada do imigrante quanto foge à mera tematização dessa condição. 


\subsubsection{Período de entre-guerras (1920-1940)}

Pela falta de perspectivas nos setores urbanos no Líbano colonizado e pelas necessidades econômicas da população rural, houve outra onda de emigrações libanesas ambiciosas e opostas ao mandato francês na região, de 1920 a 1940. Nesses 20 anos, a política do Líbano foi reestruturada, favorecendo o surgimento de uma elite francófila. Os franceses tentaram europeizar ao máximo a população através de um projeto educacional aos seus moldes e da instauração do francês como língua oficial.

Sobre esse período, no arquivo virtual da Família Doualib5, conta-se:

Finda a primeira guerra mundial, inicia-se a terceira onda de imigração de árabes para o Brasil. Em 1914 já era considerável o número de fábricas pilotadas por sírios e libaneses. (...) A crise de 1929 e o contínuo progresso da indústria nacional levam os libaneses e sírios à criação de novas indústrias e à abertura de novos estabelecimentos comerciais.

\subsubsection{Líbano independente (1943-1975) ${ }^{6}$}

O terceiro período termina com a segunda guerra mundial. Depois de 1945, os árabes brasileiros consolidam sua posição de comerciantes e industriais. Pela depressão econômica e conflitos políticos posteriores à Segunda Guerra Mundial e pelas faltas de oportunidades profissionais, houve uma terceira onda emigrações urbanas do Líbano para o Brasil.

\subsubsection{Guerra no Líbano (1975-2000)}

Pelo conflito e seu decorrente desemprego, houve uma quarta leva de emigração de civis, que saíram do seu lugar de origem, buscando a nacionalidade brasileira.

\footnotetext{
${ }^{5}$ Arquivo virtual da Família Doualib. Disponível em: $<$ http://www.familyd.net $>$. Acesso: 08/09/2012.

${ }^{6}$ Ibid.
} 
Nesse contexto imigratório, Hatoum escreve o Relato de um certo oriente, onde narrará mobilidades e deslocamentos e suas consequentes relações complexas de alteridades.

\subsection{Diferenças e tensões}

O Relato trilha relações interculturais de alteridade, parte constituinte da subjetividade humana de diferença e identidade com os outros. Consoante a Ward e Rana-Deuba (1999), as vivências das diferenças passam por uma curva de etapas heterogêneas na interação entre a cultura natal e a cultura de acolhimento: euforia, estranhamento, choque cultural, rejeição, conflito, negociação, adaptação, aceitação, aculturação (reajustamento) /transculturação e integração. Nesse processo, a aculturação constitui-se um processo de sujeição social. Observamse quatro estratégias de aculturação: assimilação, que ocorre quando os indivíduos rejeitam sua cultura minoritária e adotam as normas da cultura dominante ou de acolhimento; separação, que ocorre quando os indivíduos rejeitam a cultura dominante ou de acolhimento em favor da preservação de sua cultura de origem, a separação facilitada pela imigração para enclaves étnicos; integração, que ocorre quando os indivíduos são capazes de adotar as normas da cultura dominante ou de acolhimento, mantendo a sua cultura de origem e marginalização, que ocorre quando os indivíduos rejeitam tanto a sua cultura de origem e a cultura de acolhimento dominante. Fernanda Massebeuf (2006) notou os seguintes processos de aculturação francesa no Relato:

1) A influência francesa na cultura libanesa (o espelho é adquirido juntamente com outros objetos de decoração de estilo francês). Ela é reflexo dos tempos em que o Líbano foi colônia francesa. Desde então, no Líbano, há quem fale francês, quem aprecie a culinária francesa, quem tenha adquirido o gosto por objetos de decoração pertencentes a movimentos provenientes da França.

2) A adaptação ou não do imigrante à terra prometida, onde vai viver.

3) A exclusão do imigrante que se recusa à adaptação aos padrões de comportamento vigentes pela cultura da terra que o acolhe. A aculturação, que mostra o quanto todos nós somos suscetíveis à hibridação. Aculturação, nesse sentido, é um processo voluntário ou imposto pelos autóctones aos imigrantes, fragilizados, numa situação entre dominantes e dominados.

Nessa mobilidade migratória encontra-se, por um lado, o migrante construindo a partir das suas memórias seu imaginário nostálgico, suas narrativas sobre o Líbano, e estabelece uma 
vinculação afetiva com as imagens construídas sobre aquela vida provincial de origem. Por outro lado, o descendente mantém o Brasil como sua sociedade de destino.

Dentro da família híbrida líbano-brasileira se observa a relação inter-religiosa entre Emilie (católica) e o seu marido (muçulmano): "Emilie e o marido praticavam a religião com fervor. Antes do casamento haviam feito um pacto para respeitar a religião do outro, cabendo aos filhos optarem por uma das duas ou por nenhuma." p.69. Porém, trata-se de diferenças religiosas que não deixam de ser segregacionista porque o Eu está num lado e o Outro está no outro. É um Eu que não aprende sobre a cultura religiosa do Outro. Então, acarreta uma convivência com preconceitos negativos de uns contra outros. Percebem-se controvérsias no tocante à religião entre Emilie e seu marido, o que facilita ou não a sua adaptação a Manaus. Alguns árabes judeus e muçulmanos, como a família Benamou e o pai de Hakim no Relato mantiveram seus costumes. Em contrapartida, Emilie seguia o catolicismo e era adepta da culinária do Amazonas. Constatase que árabes cristãos como Emilie não tiveram problemas para se adaptar. Ficou a saudade de sua terra, misturada à nova rotina e à nova língua, mas assimilaram rapidamente os valores da modernidade latina, misturada ecleticamente com os valores do cristianismo e, gradualmente, formaram um grande segmento de uma classe social privilegiada. Essa modernidade consolida-se com a industrialização e o desenvolvimento do capitalismo nas cidades (KARAM, 2007). 
Figura 1: Mapa do Líbano ${ }^{7}$

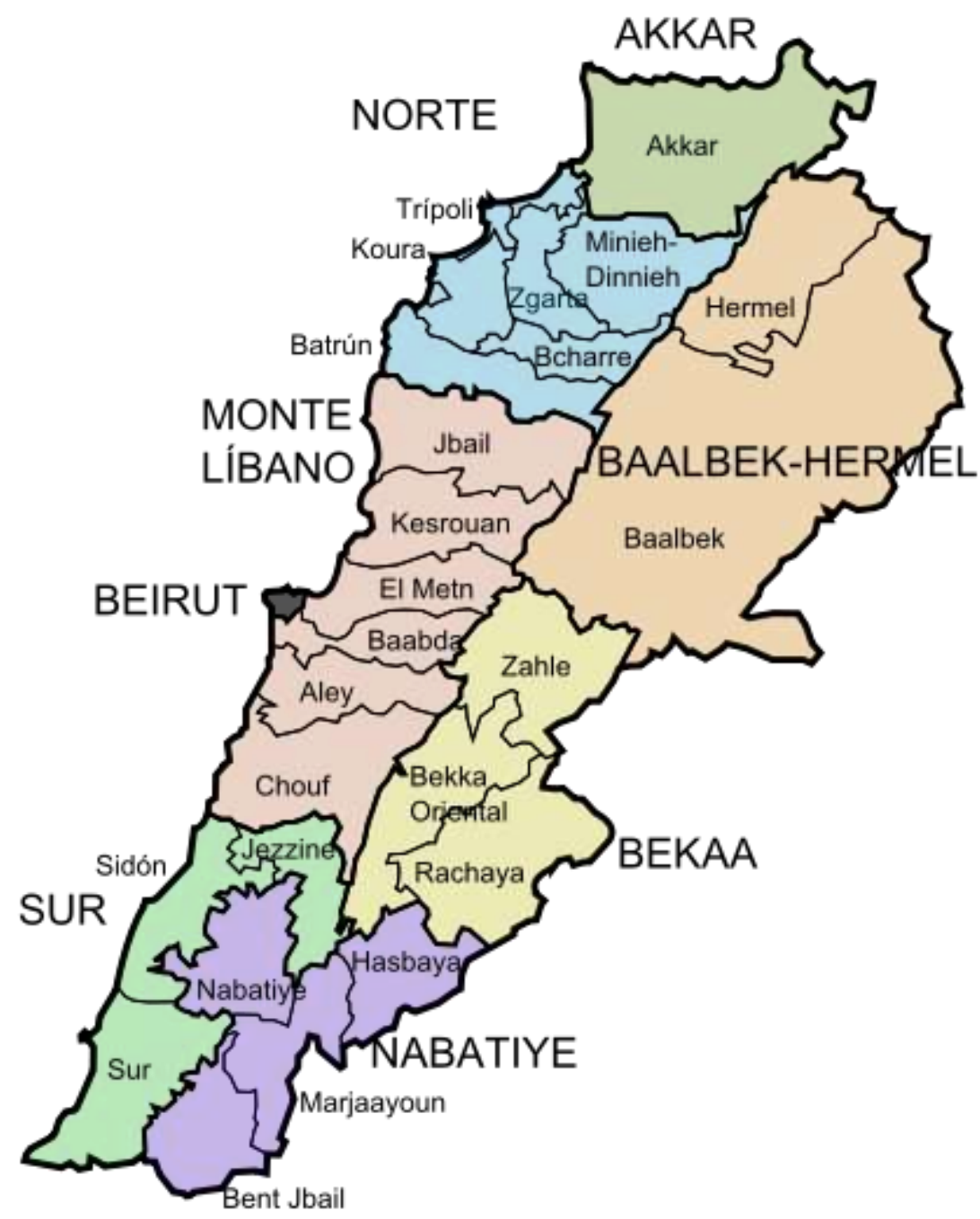

${ }^{7}$ Mapa do Líbano. Dísponível em <http://escudosybanderas.es/images/mapa-de-libano.png>. Acesso:23/07/2012. 


\section{Capítulo II: Manaus: Encontro das Águas}

"A beira de um rio ou orla marítima os aproximam, e em qualquer lugar do mundo as águas que eles veem ou pisam são também as águas do mediterrâneo" (Relato de um certo oriente, Milton Hatoum, p.76).

A cidade de Manaus originou-se da colônia criada em torno do Forte São José do Rio Negro, fundado em 1669, sendo renomeada em 1832 com o nome de Manaus, termo que na língua indígena da tribo dos Manaós, antigos habitantes do lugar, significa "mãe dos deuses" (BOLLE, 2010). Sobre a presença árabe na região de Amazonas, khatlab (2000) relata:

O historiador brasileiro Bernardo de Azevedo da Silva Ramos (1858 - 1931), nascido em Manaus-AM, em seu trabalho "Inscrições e Tradições da América Pré-Histórica, Especialmente do Brasil” (RJ - 1930), cita muitas palavras indígenas de origem fenícia, pois alguns dos tripulantes de embarcações fenícias que chegaram ao litoral permaneciam nessas regiões e constituíam clãs depois da conquista da Fenícia por Alexandre, o Grande, e depois as dominações grega e romana. Vocábulos aramaicos e mesmo árabes antigos são encontrados nos idiomas Quíchuas, Chibika, Aimará, Guarani, Tupi, sendo o Quíchua e o Tupi os mais próximos do aramaico e do árabe. Na Ilha de Marajó, foram encontradas pedras trabalhadas com inscrições aramaicas, cuja existência é datada de antes da Era Cristã. Estas se encontram no Museu Nacional do Rio de Janeiro.

De acordo com o arquivo virtual da família Doualib: "No início do século XX foi a região do Amazonas um dos pontos mais importantes de atração de grandes migrações. Os imigrantes que iam para o norte aportavam em São Luís e em Belém e destes dois portos dispersavam-se pela Amazônia. Verificava-se também um movimento de migração do sul para o norte do Brasil em função das condições econômicas advindas do Ciclo da Borracha.”. Segundo Knowlton (1955), em 1920 o número de sírios e libaneses nesse estado era de 811 pessoas, sendo que mais da metade morava em Manaus. Essa região era especialmente atraente porque o desenvolvimento através do surto econômico do Ciclo da Borracha e do café na Amazônia incentivou os sírios e os libaneses a acompanhar esse crescimento com a venda de mercadorias aos seringueiros.

No Relato de um certo Oriente, de Milton Hatoum, Manaus vira o espaço privilegiado, a cidade ilhada pelo rio e pela floresta que, desde o fim da belle époque cabocla da borracha, adaptou-se, no possível, a cada nova circunstância dada pelo desenvolvimento. Nesse sentido, 
pode ser compreendida como uma alegoria da história do país, uma parte, num pequeno mundo, a ele circunscrita, a gerar valores humanos específicos, fazendo, dessa forma, a passagem do local para o universal. Um espaço sócio-cultural e histórico, formado por estratos humanos que se cruzam e se misturam, quase desaparecendo: o estrato indígena, o do imigrante estrangeiro, o do migrante de outras regiões do país.

Em Manaus chegaram imigrantes árabes que buscavam sobreviver. Instinto de querer viver, ou melhor, escapar da pobreza, da doença, da miséria, do desemprego e da falta de oportunidades de trabalho e estudo. Chegaram cansados ao Porto de Manaus e a outros portos de Brasil. Logo, vemos núcleos familiares árabes incorporados ao sistema social e político no Brasil. Seus descendentes terão que recriar sua identidade entre prazeres e traumas. Hatoum, Hakim no Relato, veio de uma família misturada de um muçulmano, inominável no Relato, e a protagonista católica Emilie.

\subsection{Fim do Ciclo da Borracha}

Após o Ciclo da Borracha, a ditadura militar (1964-1985) faz emergir um tipo de "modernização conservadora" à região amazônica. Em 1967, foi criada a Zona Franca de Manaus. A partir de segunda metade da década de 1970, estruturou-se em 1972 o Polo Industrial de Manaus (PIM), em que predominava o setor eletroeletrônico. Como bem explica Noemi de Perdigão (2011): “De 250 mil habitantes em 1967, Manaus passou a 2 milhões de habitantes segundo o último censo do IBGE (2010), com todos os problemas sociais e ambientais que um crescimento urbano nesta proporção implica”. Em relação ao retorno de Hatoum à Manaus da Zona Franca, Bruno Leal (2010) conta:

Depois de dezesseis anos longe do Amazonas e de Manaus, Milton Hatoum teve um impacto negativo quando chegou à cidade de sua infância e adolescência; muita coisa havia mudado. Uma cidade corroída pela falta de políticas públicas, o patrimônio arquitetônico da cidade totalmente abandonado, milhares de indigentes vindos de todo o país em busca de emprego na Zona Franca de Manaus. (...) Portanto, o que restou para o artista amazonense? A saída para o Sul do país ou para o exterior e, por último, a degradação física e intelectual para os que tentaram resistir contra uma política aniquiladora e mesquinha por parte do governo militar nos idos da Zona Franca de Manaus. 
A cidade passou de "Paris nos trópicos" para uma "Cidade Flutuante", um "verdadeiro bazar oriental”, com pessoas de várias partes do mundo.

Figura 2: Loja de temperos no centro de Manaus (Maged El Gebaly, Manaus, 16/05/2012).

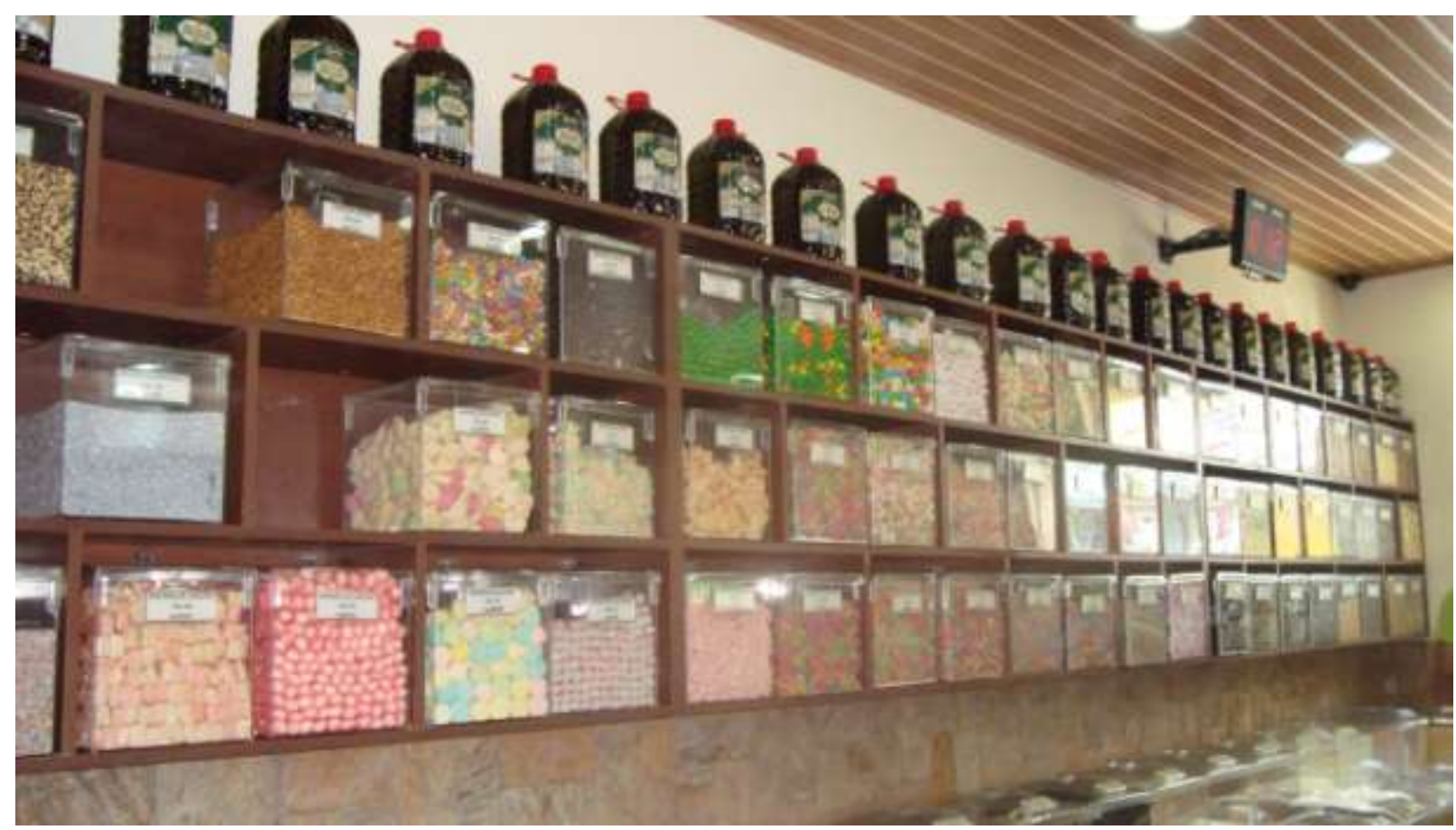




\subsection{Além do regionalismo, incerto oriente}

Figura 3: Mapa do Brasil (Fonte: IBGE, 1999).

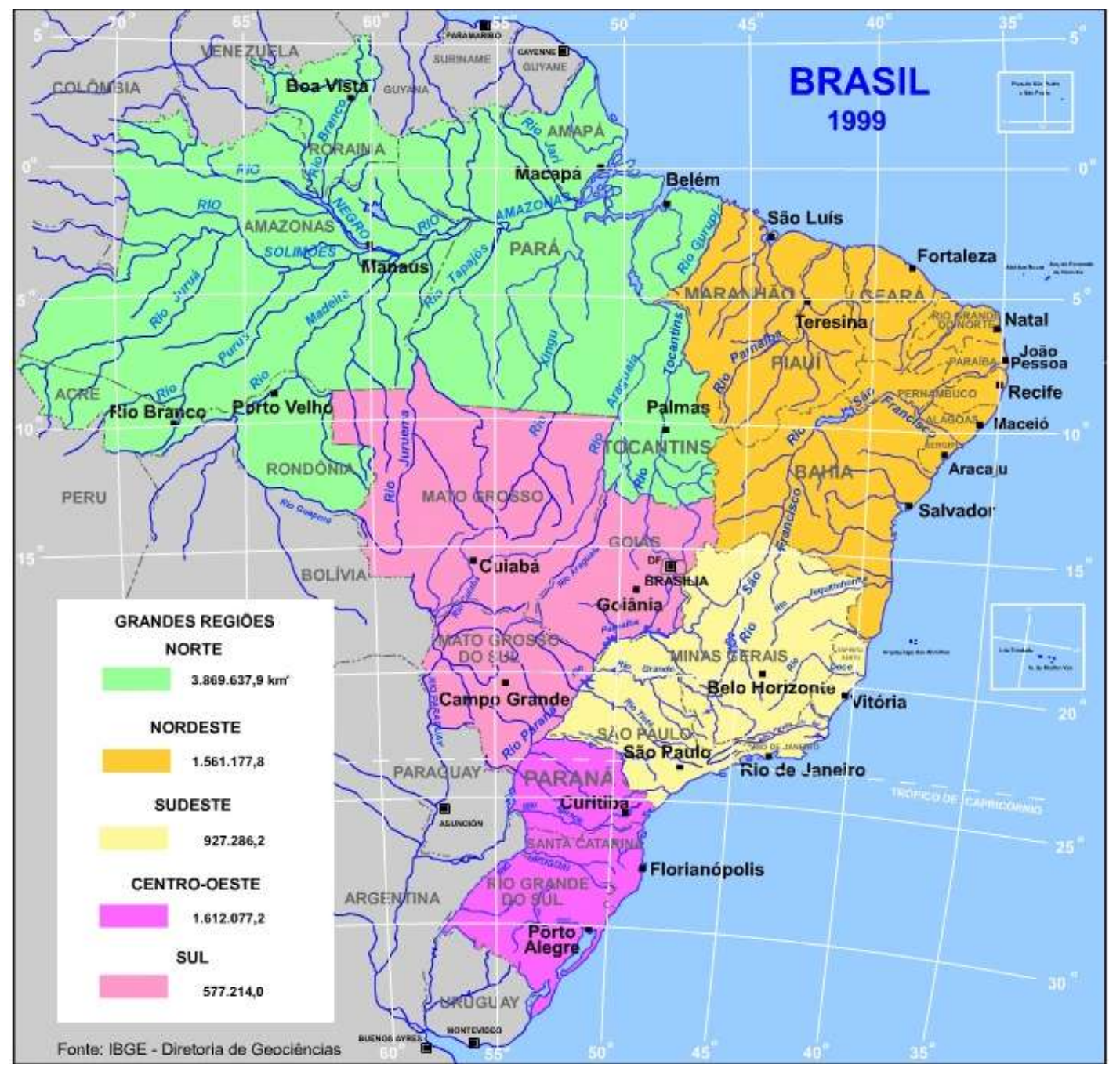

Norberto Bobbio (2000), apud FIGUEIREDO (2010), concebe o regionalismo como "tendência política dos que são favoráveis às autonomias regionais.”. José Maurício Gomes de Almeida define o regionalismo como "aquela arte que buscaria enfatizar os elementos diferenciais que caracterizam uma região em oposição às demais ou à totalidade nacional” (ALMEIDA, 1981, p.47). Norbert Elias (2000) apud FIGUEIREDO (2010) considera regionalismo como uma forma de "afixar o rótulo de valor humano inferior a outro grupo" e o considera "uma das armas usadas pelos grupos superiores nas disputas de poder como meio de manter a superioridade social. Nessa 
situação, o estigma social imposto pelo grupo mais poderoso ao menos poderoso costuma penetrar na autoimagem deste último e, com isso, enfraquecê-lo e desarmá-lo”.

No entanto, Maria Luiza Germano de Souza (2010) apela à definição de Antonio Candido (1985) do regionalismo no Brasil:

Chama de terceira fase do regionalismo para a América Latina e Brasil: o superregionalismo, no que se tem uma "consciência dilacerada do subdesenvolvimento", algo que tornou possível a universalização da região, em razão dos escritores terem ultrapassado o pitoresco e o documentário. Isto é, importa menos o retrato de uma dada região e mais a forma escolhida para dar expressão e virtuosismo ao narrado. Candido identifica no regionalismo brasileiro, que oscila entre o fato de ser potencialmente "instrumento de descoberta e autoconsciência do país" ou "ideologia que mascara as condições de dominação do homem pobre no campo".

Márcio Souza acredita que o regionalismo em contraponto ao universal são categorias políticas inventadas pela indústria cultural eurocêntrica imperialista para hierarquizar certas regiões supostamente mais próximas dos valores eurocêntricos. No Humanismo e crítica democrática (2007), Said faz ênfase na necessidade de desenvolver uma crítica oposicional ao eurocentrismo presente na ordem e na genealogia do discurso epistemológico positivista do século XIX. Para o crítico palestino, o humanismo democrático não parte de uma verdade única que elimina diferentes formas de pensar, mas da diversidade entre as culturas, o que não cria conflitos entre as verdades essencializados, que têm suas raízes na colonização, diante da crescente complexidade do mundo. Na visão do Said, as culturas podem coexistir não em base de uma essência, mas na forma de um dialogo que procura entender a diversidade humana. Nesse contexto, Ademar Leão (2005) ressalta a posição critica de Hatoum perante o binarismo do olhar eurocêntrico:

As narrativas que concorrem para a construção das matrizes identitárias do Ocidente apresentam um aspecto relevante em comum: o etnocentrismo que circunscreve a sua representação do Outro. Esta visão etnocêntrica, que opera uma radical divisão do mundo entre "civilizados" e "bárbaros" e que recusa a reconhecer o Outro em sua alteridade, corresponde a um expediente a partir do qual, negando ao Oriente uma possibilidade de representação, o Ocidente atribui-lhe uma identidade construída à sua imagem e semelhança...Posicionando-se contrariamente à postura restritiva do regionalismo literário, cuja lógica sustenta-se na circunscrição da obra a uma 
geografia e a um vocabulário determinado, o texto de Hatoum põe em questionamento a inviabilidade, no mundo contemporâneo, da manutenção de concepções identitárias aprisionadas em contornos unívocos, fixos, e reivindica, assim, um espaço para a manifestação da diferença e da alteridade na literatura brasileira.

Para Coutinho (1969), apud FIGUEIREDO (2010), “o regionalismo é um conjunto de retalhos que arma o todo nacional". Ele sustenta a existência de "regiões de produções literárias" constituídas da seguinte forma: Ciclo nortista, Ciclo nordestino, Ciclo baiano, Ciclo central, Ciclo paulistano e Ciclo gaúcho. A esses se juntaria uma espécie de subciclos suburbanos. Hatoum perscruta o regional somente como localização e/ou ambiente de suas narrativas, porém o relevo é dado pelas idiossincrasias humanas vividas pelas personagens. Estas regiões literárias dialogam com a tese da mestiçagem étnica de Darcy Ribeiro (1999) de um Brasil constituído históricamente em seu interior por varios traços arquetípcos de Brasis imaginados apartir dessa hibridação: O Brasil crioulo, o Brasil caboclo, o Brasil sertanejo, o Brasil Caipira, o Brasis sulinos. Para Coutinho, o regional toma importância no Brasil a partir do romantismo que procura a exaltação do brasileiro em oposição ao europeu. Coutinho adverte a diferença do regionalismo realista que desviou-se do saudosismo e escapismo do regionalismo romântico.

Alfredo Bosi (1976) aponta um regionalismo pré-moderno ${ }^{8}$, que parte de um nacionalismo declamatório e um regionalismo sério, inspirado num nacionalismo crítico que surge com o Primeiro Congresso Brasileiro de Regionalismo, uma agitação intelectual que suscitou o aparecimento do romance nordestino de 30. De 1930 até a Segunda Guerra Mundial, marca uma segunda fase do modernismo, que é a da estabilização das conquistas modernas. Nesse período, encontramos autores como José Américo de Almeida, Raquel de Queiroz, José Lins do Rego, Graciliano Ramos e Jorge Amado. Terceira fase do modernismo surge uma tendência para o hermetismo e para o intelectualismo do final da segunda guerra mundial até nossos dias, Os principais autores desse período são Clarice Lispector, João Guimarães Rosa, José Candido de Carvalho e Pedro Nava (FIGUEIREDO, 2010).

\footnotetext{
${ }^{8} \mathrm{O}$ modernismo como movimento contra os tabus, o academismo, o elitismo, a estética que a França ditava, e a repressão ideológica dominante, emerge no Brasil com a Semana de Arte Moderna realizada em São Paulo em 1922, foi o ponto a partir do qual se desenvolveram grupos e autores ligados à realidade cultural moderna. Dos autores modernistas da primeira fase Mário de Andrade, Oswald de Andrade e Manuel Bandeira.
} 
O crítico uruguaio Hugo Achugar (1996), apud FIGUEIREDO (2010), reflete sobre a relação entre o regionalismo e o coneito da narrativa heterogênea de CORNEJO-POLAR, uma narrativa caracterizada pela duplicidade ou pluralidade dos signos socioculturais do seu processo produtivo, o que cria necessariamente uma zona de ambiguidade. Achuga discute o desafio da integração das experiências culturais heterogeneas nos panoramas da acelerada homogeneização da globalização. Achugar apela ao cruzamento da tese das regiões literárias com a proposta de "panoramas" de Arjun Appadurai, para entender melhor as novas interpretações perspectivadas da realidade atual: a) etnopanorama, b) tecnopanorama, c) finançopanorama, d) midiapanorama e e) ideopanorama. A etnopanorama compreende as pessoas em trânsito como os imigrantes, os exilados.

Pellegrini (2007), apud TÔNUS (2005) adverte que Hatoum foge do dramatismo com a epístola. As obras de Hatoum não se centram na ação e usam o recurso da exploração do tempo como "canção sequestrada". Situação curiosa, pois uma das marcas da narrativa na modernidade é a fragmentação do tempo em prol da ação, algo explicado pelo apelo ao leitor moderno que não tem mais tempo e vive apressado, em busca de resultados imediatos mesmo quando na leitura.

Milton Hatoum, em entrevista ao Jornal Folha de São Paulo, faz a seguinte afirmação em relação ao regionalismo literário:

A literatura regionalista esgotou-se há muito tempo. O regionalismo é uma visão muito estreita da geografia, do lugar, da linguagem. É uma camisa de força que encerra valores locais. Minha ideia é penetrar em questões locais, em dramas familiares, e dar um alcance universal para eles (2005, p. 12).

Hatoum era um bom leitor da obra do intelectual palestino Edward Said (1995), que dizia:

O Oriente não é um fato inerte da natureza. Não está meramente lá, assim como o próprio Ocidente não está apenas lá. [...] os lugares, regiões e setores geográficos tais como o «Oriente» e o «Ocidente» são feitos pelo homem.

Ele traduziu as palestras de Said Representações do intelectual (2005) para o português e recomendou para a editora Companhia das Letras a tradução de Orientalismo (SAID, 2007). Com respeito a isso, Milton Hatoum (2010) nos contou: 
O Orientalismo, livro de Edward Said, foi uma das leituras mais importantes sobre a construção imaginária do discurso sobre o outro oriental, sobretudo sobre o mundo islâmico. O Orientalismo é um dos ensaios seminais sobre as relações entre o Oriente e o Ocidente, sendo que o Oriente, como Said mostrou, é uma construção, é uma invenção do Ocidente. É um tipo de representação que o discurso orientalista teceu ao longo da história, sobretudo a partir do século XVIII.

Em "Passagem para um certo Oriente", Hatoum (1993) escreve sobre a importância que teve para ele o contato com o Oriente borgiano. Mais do que isso: conta como se interessou por autores orientalistas após ter peregrinado pelos labirintos de Borges. E foi assim, com as indicações de leitura do escritor argentino, que ele se mudou para a Europa, onde conheceu arabistas e traduções de obras árabes.

Numa crônica titulada “As Mil e uma noites: em busca de um estilo", na primeira página da seção de Cultura do Estado de São Paulo, em Outubro 1991, Hatoum disse:

$\mathrm{Eu}$ apreciava alguns escritores europeus que, sintonizados com o renascimento oriental, escreveram obras que valorizam a cultura "excêntrica", em oposição a uma cultura que se pretende mais complexa e artificial, produzida no "centro", na Europa. Nossas peregrinações ao Oriente procuravam às vezes uma outra pátria, ou um lugar ideal para o sonho e o devaneio, como alguém que busca na paisagem estrangeira o avesso da casa em que habita. Para Gerard Nerval, o Egito é um país de mistérios e enigmas (...). Outras vezes esses escritores se armam de um projeto etnocêntrico, em que a glória pessoal de uma descoberta geográfica se mescla aos serviços prestados à pátria. $\mathrm{O}$ projeto literário serve ao expansionismo colonial. (...) Diante de textos tão díspares, fiz como um leitor que pratica um ritual de canibalismo literário, assimila o que lhe dá prazer. Com isso, quero dizer que a literatura árabe foi tão importante quanto os textos orientalistas, e esse duplo interesse residia sobretudo no encanto da linguagem, como nos contos de As Mil e Uma Noites ou na Viagem ao Oriente, de Nerval.

Alguns leitores procuram no Relato a imagem "dos árabes" sem se dar conta de que o mundo árabe abrange 23 países, cada país contendo variedades ecológicas e culturais próprias. Notamos que Halbwachs (1990), não deixa de considerar que aquele que se lembra não é o grupo, mas o indivíduo, havendo diferenças entre os sujeitos nas formas de se remeter ao passado e rememorar. Contudo, a memória individual poderia ser encarada, conforme seu entendimento, como "um ponto de vista" acerca da memória coletiva. 
No mais, se a memória coletiva tira sua força e sua duração do fato de ter por suporte um conjunto de homens, não obstante eles são indivíduos que se lembram, enquanto membros do grupo. Dessa massa de lembranças comuns, e que se apóiam uma sobre a outra, não são as mesmas que aparecerão com mais intensidade para cada um deles. Diríamos voluntariamente que cada memória individual é um ponto de vista sobre a memória coletiva, que este ponto de vista muda conforme o lugar que ali eu ocupo, e que este lugar mesmo muda conforme às relações que mantenho com outros meios. Não é de admirar que, do instrumento comum, nem todos aproveitam do mesmo modo. Todavia, quando tentamos explicar essa diversidade, voltamos sempre a uma combinação de influências que são, todas, de natureza social (Halbwachs, 1990:51).

Dessa maneira, a cultura árabe representada no Relato é uma autoficção construída a partir de uma experiência pessoal de descendente de imigrantes libaneses na cidade de Manaus e certamente cruza com as culturas árabes em certos aspectos e se distancia em muitos outros das realidades árabes atuais. Portanto, é importante levar em conta que o livro faz um recorte de um grupo pequeno e específico da cultura árabe, e evitar uma leitura estereotipada de generalizações.

Destarte, o Relato de um certo oriente representa uma crítica implícita ao discurso orientalista. O Brasil do Rio Amazonas é retratado como um "oriente" híbrido, à diferença das imagens naturalistas inventadas e estereotipadas pela visão europeia sobre o Amazonas. Hatoum consegue escapar da visão regionalista romântica que fazia ênfase na floresta amazônica como personagem em primeiro plano e recria "um certo oriente" a partir das misturas culturais, que circulavam ao redor de um sobrado em Manaus e da loja "Parisiense" (FREITAS, 2001).

Por isso, Milton, leitor e tradutor de Edward Said, faz um paratexto, ou seja, uma intertextualidade com o título Orientalismo do crítico palestino e vai descartando no seu Relato esta visão exótica horizontal "orientalista" do romantismo e das descrições naturalistas que continuam vivas hoje nos discursos essencialistas que supõem a existência de um choque de civilizações que divide o mundo em blocos com fronteiras religiosas e raciais rígidas.

Na sua obra Orientalismo, Said $(1978,2007)$ vai desconstruindo o discurso tecido pelos orientalistas europeus e estadunidenses durante os séculos XVIII e XIX, do imaginário deturpado do outro não europeu. Said faz uma crítica contrapontual ao discurso acadêmico colonial eurocêntrico, que generaliza e estereotipa a imagem de Oriente sob o nome de "orientalismo", uma área de estudo que abarca filólogos e historiadores especializados nas línguas orientais e 
suas letras desde uma ótica colonialista. A genialidade da obra de Said se revela principalmente na sua consciência crítica do Orientalismo que, enquanto se apresentava como um conhecimento esclarecido de pensamento iluminista, tinha ligação direta com as práticas de poder do colonialismo. Segundo o autor, o colonizador criou uma consciência falsa do Oriente, numa tentativa de diferenciação que servia os interesses do colonialismo. Said analisou uma série de discursos literários, políticos e culturais, nos quais encontrou um denominador comum: a representação dos povos não europeus como bárbaros. Assim que Hatoum (2010) nos relatou:

Pode ser que haja, inconscientemente, uma influência do Edward Said no título. A verdade é que foi difícil encontrar este título. Para mim foi um achado. Eu já havia praticamente terminado o romance e tinha outros títulos em mente, como "Retratos da memória". Eu lembro que esse era um dos títulos possíveis, mas gostei desse título Relato de um certo oriente, porque nele há várias perguntas. De que Oriente nós estamos falando? De um determinado Oriente? Mas qual deles? É isso que o livro insinua. É o mistério em torno desse Oriente que está um pouco nebuloso, e ainda não se sabe qual é o Oriente do romance. O leitor não sabe exatamente do que se trata esse Oriente. A literatura trabalha com a ambiguidade, isso a enriquece. Tudo o que é muito determinado ou explicado prejudica o romance. O romance questiona, indaga, insinua, suscita perguntas; mas ele não pode explicar. O romance explicativo é chatíssimo.

De acordo com Morin (2011), “o conhecimento continua sendo a navegação em um oceano de incertezas, entre arquipélagos de certezas..." da gestão criadora da incerteza e da desordem nascea organzição de uma nova ordem. Milton Hatoum numa entrevista com Kanzepolsky (2002) afirma que a literatura trabalha com a imaginação, o esquecimento como uma das formas da memória - não como recordação cristalizada do passado - mas como memória implícita do devir, oculta e involuntária de cenas de prazer e de traumas que repercute no presente. Reinventar e lembrar são manifestações do mesmo movimento, a memória estaria na condição de dar conta do invisível. A realidade e a ficção são nebulosas, sem ser necessariamente sombrias, na fronteira entre memória e imaginação são quase irmãs (KANZEPOLSKY, 2008).

Desde a relativização de "um certo oriente" no título, Hatoum coloca sua ficção no espaço pós-colonial e supera a retórica holística das narrativas totalitárias e hegemônicas do imperialismo, do colonialismo, do orientalismo, das identidades coletivas limitadas, e a redução da História aos documentos escritos. O Relato possui, desde o título, marcas de seu caráter híbrido árabe-brasileiro. A escolha do artigo indefinido junto com o pronome indefinido "certo" 
relativiza a ideia do Oriente como um bloco único, pois faz um recorte de um Oriente dentre muitos que existem e que podem existir. A escolha dos termos dá ao título uma ambiguidade através da qual a expressão "um certo oriente" é capaz de, ao mesmo tempo, precisar a escolha do oriente específico a ser relatado e também de indeterminar, já que evoca a ideia da pluralidade de orientes existentes, de modo que o oriente escolhido é apenas um entre tantos. 


\section{Capítulo III: Memória cultural e autoficção}

Já não coleciono selos. O mundo me inquizila.

Tem países demais, geografias demais.

Desisto.

Nunca chegaria a ter um álbum igual ao do Dr. Grisolia,

orgulho da cidade.

E toda gente coleciona

os mesmos pedacinhos de papel.

Agora coleciono cacos de louça

quebrada há muito tempo.

Cacos novos não servem.

Brancos também não.

Têm de ser coloridos e vetustos,

desenterrados - faço questão - da horta.

Guardo uma fortuna em rosinhas estilhaçadas,

restos de flores não conhecidas.

Tão pouco: só o roxo não delineado,

o carmezim absoluto,

o verde não sabendo

a que xicara serviu.

Mas eu refaço a flor por sua cor,

e é só minha tal flor, se a cor é minha

no caco de tigela.

O caco vem da terra como fruto

a me aguardar, segredo

que morta cozinheira ali depôs

para que um dia eu o desvendasse.

Lavrar, lavrar com mãos impacientes

um ouro desprezado

por todos da família. Bichos pequeninos

fogem de revolvido lar subterrâneo.

Vidros agressivos

ferem os dedos, preço

de descobrimento:

a coleção e seu sinal de sangue;

a coleção e seu risco de tétano;

a coleção que nenhum outro imita.

Escondo-a de José, por que não ria

nem jogue fora esse museu de sonho.

Coleção de cacos, Boitempo II, 1973.

Carlos Drummond de Andrade 
Maurice Halbwachs (1990) criou o termo memória coletiva para distinguir da memória individual. Ele considerava a memória uma experiência partilhada, transmitida e também construída pelo grupo ou sociedade:

Outros homens tiveram essas lembranças em comum comigo. Muito mais, eles me ajudam a lembrá-las: para melhor me recordar eu me volto para eles, adoto momentaneamente seu ponto de vista, entro em seu grupo, do qual continuo a fazer parte, pois sofro ainda seu impulso e encontro em mim muitas das ideias e modo de pensar a que não teria chegado sozinho" (HALBWACHS, A Memória Coletiva, 1990).

Respeito ao conceito social da memória coletiva de Halbwachs, Sonia Crisitina Hamid (2007) explica que:

Para Halbwachs, os "quadros sociais" funcionam como indutores das recordações, sendo as formas pelas quais a matéria caótica das lembranças pode emergir à consciência de modo ordenado...Aqui é importante colocar que Halbwachs estabelece uma diferenciação entre memória e lembrança. A memória seria o resultado de um trabalho realizado sobre um conjunto desordenado de imagens... Ao entender a memória não como sonho, mas como trabalho, Halbwachs estabeleceu uma crítica profunda ao pensamento bergsoniano de que a lembrança é uma conservação total do passado e sua ressurreição, mostrando que a menor alteração do ambiente atinge a qualidade íntima da recordação.

Michael Pollak (1992) concorda com Halbwachs de que a memória é um fenômeno social, sendo mutável e flutuante, também aponta para uma suposta fixidez e rigidez de algumas lembranças, afirmando que existem marcos e pontos relativamente invariantes e imutáveis na memória. Estes elementos se repetiriam constantemente na fala dos indivíduos, podendo ser considerados pontos chaves que ajudam a constituir o sentimento da identidade do sujeito, que está permanentemente ligado à memória:

A memória é um elemento constituinte do sentimento de identidade, tanto individual como coletiva, na medida em que ela é também um fator extremamente importante do sentimento de continuidade e de coerência de uma pessoa ou de um grupo em sua reconstrução de si. 
Ao tentar desvendar os elementos constitutivos da memória individual ou coletiva que influenciam nas percepções que os indivíduos assumem de si e dos outros, Pollak (1992) aponta para a importância de acontecimentos vividos, vividos por tabela e acontecimentos herdados.

Enquanto os primeiros seriam vividos pessoalmente pelos sujeitos, os segundos seriam acontecimentos dos quais a pessoa nem sempre participou, mas que tomaram tamanha importância em seus grupos, que já não se sabe dizer se houve mesmo participação ou não. Já as memórias herdadas não fariam parte do espaço-tempo de uma pessoa, mas por meio de um forte processo de socialização política e histórica, ocorre um fenômeno de projeção e identificação com determinado passado.

Também, Myrian Sepúlveda dos Santos (1998) ressalta a relação entre identidade e memória:

(...) identidade que rompe com as dicotomias entre indivíduo e sociedade e passado e presente, está tão associada à ideia de memória como esta última à primeira...O sentido de continuidade e permanência presente em um indivíduo ou grupo social ao longo do tempo depende tanto do que é lembrado (esquecido e silenciado), quanto o que é lembrado depende da identidade de quem lembra.

Nesse mesmo sentido, Ecléa Bosi, (2004) aponta a memória como uma construção social:

Conhecemos a tendência da mente de remodelar toda experiência em categorias nítidas, cheias de sentido e úteis para o presente. Mal termina a percepção, as lembranças já começam a modificá-la: experiências, hábitos, afetos, convenções vão trabalhar a matéria da memória. Um desejo de explicação atua sobre o presente e sobre o passado integrando suas experiências nos esquemas pelos quais a pessoa norteia sua vida. $\mathrm{O}$ empenho do indivíduo em dar um sentido à sua biografia penetra as lembranças com um "desejo de explicação". (ECLÉA BOSI, 2004, p. 55)

Para entendimento da natureza da memória humana, tentaremos construir nossas interpretações literárias com base no diálogo com as teorias científicas sobre a memória. Como afirma Lehrer (2010), "a ciência necessita da literatura para emoldurar o mistério, mas a literatura necessita da ciência para que nem tudo seja um mistério".

Após suas leituras dos estudos de Maurice Halbwachs sobre "memória coletiva", o egiptólogo Jan Assmann (apud Aleida Assmann, 2011) cunhou o termo "memória cultural" para diferenciá-lo do arquivo histórico, que é um armazenador, e para referir-se à construção da 
memória coletiva por meio das formas simbólicas como as narrativas de memória, escritas subjetivas e pessoais das imagens marcantes das lembranças pessoais. O conceito de "cultura" aqui se refere a "um modo próprio de ser do homem em coletividade, que se realiza em parte consciente, em parte inconscientemente, constituindo um sistema mais ou menos coerente de pensar, agir, fazer, relacionar-se, posicionar-se perante o Absoluto, e, enfim, reproduzir-se. ${ }^{9, "}$

A ficcionalização da memória cultural é um processo da reinvenção consciente do inconsciente simbólico na nossa própria vida e na dos outros. A memória cultural ficcionalizada é visualização de imagens passadas para o futuro. Nessa narrativa, o distanciamento e a aproximação, como atos temporais da memória, se dão por meio da rememoração. O escritor recorre à rememoração através da imaginação para a configuração de uma narrativa de identidade, de lembranças de experiências orais e de hábitos a partir de encontros e desencontros com lembranças de prazeres, de conflitos e de traumas com experiências pessoais que possa ter registro material físico ou não. Como afirma Hatoum na sua entrevista com KANZEPOLSKY (2002), "o relato tem mais afinidade com um tipo de literatura intimista memorialista, na qual o distanciamento temporal da memória é importante para poder voltar através dela para a infância e a juventude".

Nosso olhar se volta para o passado, a fim de estocar os dados e nos situar ao longo do tempo. Sentimos como nos diz Huyssen (1996), um profundo sentimento de crise, associado à doença de nossa cultura que experimenta sua fase terminal de amnésia. A arte desempenha um papel importante na rememorização de vozes esquecidas reveladoras de "passado presente": A fissura que se opera entre experienciar um acontecimento e lembrá-lo como representação é inevitável. Esta separação deve ser compreendida como um vigoroso estimulante para a criatividade artística. Huyssen (1996) articula alguns dos elementos centrais de um "pósmodernismo de resistência" como: 1) manter uma crítica da modernização, especialmente no seu sentido imperialista e de devastadora do meio ambiente; 2) atenção à centralidade das questões de gênero e sexualidade na sociedade, na cultura e na política e 3) promover a revalorização de culturas não-européias e não-ocidentais. Trata-se de um pós-modernismo que duvida das noções clássicas de verdade, razão, identidade e objetividade, da ideia de progresso e emancipação

\footnotetext{
${ }^{9}$ Pereira Gomes, Mércio. Antropologia. São Paulo: Editora Contexto, 2011.
} 
universais, de estruturas únicas, grandes narrativas ou fundamentos definitivos de explicação. Reflete alguma coisa dessa mudança de uma época caracterizada pela profusão de fragmentos e incertezas, numa arte pluralista, superficial, descentralizada, infundada, autoreflexiva, divertida, derivativa, eclética, que torna indistintas as fronteiras entre cultura 'alta' e cultura 'baixa', bem como entre arte e experiência cotidiana (EAGLETON, 1997; apud FIGUEIREDO, 2010).

Num mundo movediço como as areias do deserto psicológico do exílio e da diáspora do homem contemporâneo, Milton cria uma narrativa moderna, ou seja, subjetiva e relativa. (MOREIRA, 2007 e VIEIRA, 2008). Os espaços se apresentam na narração simultaneamente ao momento vivido pela relatora. Ainda que a história do relato aconteça na época de 1950, na narração do Relato, Milton funde passado, presente e futuro (FREIRE, 2006).

Disse Huyssen (1996): "As convulsões mnemônicas de nossa cultura parecem mais caóticas, fragmentárias e flutuantes”. Elas não parecem ter um foco político ou territorial claro, mas sem dúvida expressam a necessidade transcultural por uma "âncora temporal", pela crescente mobilidade em todo o mundo. Por isso, no Relato de memória de Hatoum há estrutura fragmentada e híbrida de vozes e tempos não lineares. A memória é então recriada lacunamente pela mediação de entrelugares de vozes fragmentárias, imprecisas, e conscientes da impossibilidade de recuperação do vivido. Huyssen (1996) explica que o modo de memória é a busca, não a recuperação. A memória humana encontra-se intimamente ligada às maneiras como uma cultura constrói seu imaginário e sua temporalidade vertical. O relógio da casa de Emilie é indício de uma temporalidade paralisada que corresponde à realidade íntima da narradora.

É uma narrativa de uma identidade em crise, embora o escritor reinterprete a realidade através da evocação de imagens e experiências sensoriais de matérias como fotos, cadernos, objetos pessoais, cartas, cheiros marcados para o resgate desta memória cultural do esquecimento. Misturam-se processos de construção da narrativa e de (ordenação) das lembranças e cria-se com esse distanciamento, espaço para a reflexão sobre o passado, sobre a impossibilidade da recuperação fiel do tempo vivido. Na voz do narrador de Dois Irmãos $^{10}$ se lê: "a memória mesmo inventa quando quer ser fiel ao passado" (HATOUM, 2000).

\footnotetext{
${ }^{10} 10$ Dois Irmãos foi traduzido para árabe por Profa. Dra. Safa Jubran Abou Chala (USP) e publicado pela Editora Al Farabi, Beirut, 2002. Para maiores informações sobre as traduções da obra de Milton Hatoum recomendo Consultar:
} 
Quantas vezes recomecei a ordenação dos episódios, e quantas vezes me surpreendi ao esbarrar no mesmo início, ou no vaivém vertiginoso de capítulos entrelaçados, formados de páginas e páginas numeradas de forma caótica (HATOUM, 1989, p.165).

\subsection{Memória familiar e sombras da infância}

Milton Assi Hatoum, nascido no dia 19 de agosto 1952, em Manaus, no seio de uma família libanesa, resgata suas lembranças familiares. Ao respeito Antonaccio (1996, p.236) conta:

Foi assim que o imigrante Mamed Ali Assi veio parar no Amazonas, iniciar um comércio ambulante ou teco-teco como eu prefiro nominar e constituir, até meados do século XX, um verdadeiro império empresarial com sua famosa e conhecidíssima loja A Esquina das Sedas.

Hatoum começou a escrever o Relato (1989) em Paris, quando recebeu a notícia da morte do seu avô, que era o narrador oral da sua infância. Parece que a morte do avô incitou o escritor a penetrar nas memórias da família como grupo social de afinidade e descendência. Hatoum cria sua ficção narrativa a partir da imaginação, parcialmente baseada em fatos reais de família e especialmente as narrativas do avô materno (MOREIRA, 2012). Assim, o escritor manauara vai explorando, desde 1910 até os anos de 1980, memórias da sua própria vida e dos relatos escutados no âmbito da família e dos amigos:

Eu parto da família. O núcleo familiar é importante porque faz parte de uma história local. (...) a literatura fala do particular. A literatura sobre generalidade não aprofunda muita coisa. Então, minha vivência na família arabo-amazônica foi importantíssima. Não só a minha família, mas a dos vizinhos, dos caboclos, dos empregados, dos pescadores. Eu saía muito para pescar em Manaus com meu avô, que era um grande contador de histórias. Então, meu primeiro livro foi “ouvido" (Hatoum. In: GONÇALVES FILHO, 2000:13).

Hatoum, Milton, entrevista com Maged El Gebaly, Milton Hatoum: "Não há tantos tradutores de literaturas de língua portuguesa", Revista Eletrônica Crioula da USP, número 7, maio 2010, página visitada 10 de junho 2010. 


\title{
3.1.1. Casamento misto
}

\author{
Conta Antonaccio (1996):
}

Mamed Ali Assi era casado com a Sra. Emily Ali Assi e tornaram-se conhecidos em Manaus pelo bom gosto de suas confecções, sedas finíssimas importadas, botões e adornos para roupas das mais variadas espécies. Vinha tudo da Suíça, da França e da Inglaterra e de outros países da Europa para suprir a cidade que ainda aspirava um pouco à era do fausto da borracha, a sociedade amazonense costumava sair à noite para vislumbrar, nas vitrinas da loja, A Famosa Noiva do Mês.

Sobre sua vida na escola, nos conta Antonaccio (1996):

O escritor inicia seus estudos no então colégio Barão Rio Branco, escola pública primária que atendia às famílias da elite manauara, e, logo depois, Milton Hatoum vai estudar no então conhecido Colégio Estadual do Amazonas que, na época, chamava-se Ginásio Amazonense D. Pedro II, e que também recebia os filhos da elite política e econômica da cidade de Manaus. (...) Inesgotável celeiro de figuras de realce de nossa cultura, cenário de movimentos decisivos na estrutura educacional do Amazonas. Formador de grandes quadros que atuaram no campo político, econômico e artístico na cidade e Manaus (ANTONACCIO, 1996, p. 175).

Figura 4: Gimnasio Amazonense Pedro (Maged El Gebaly, Manaus, 16/05/2012).

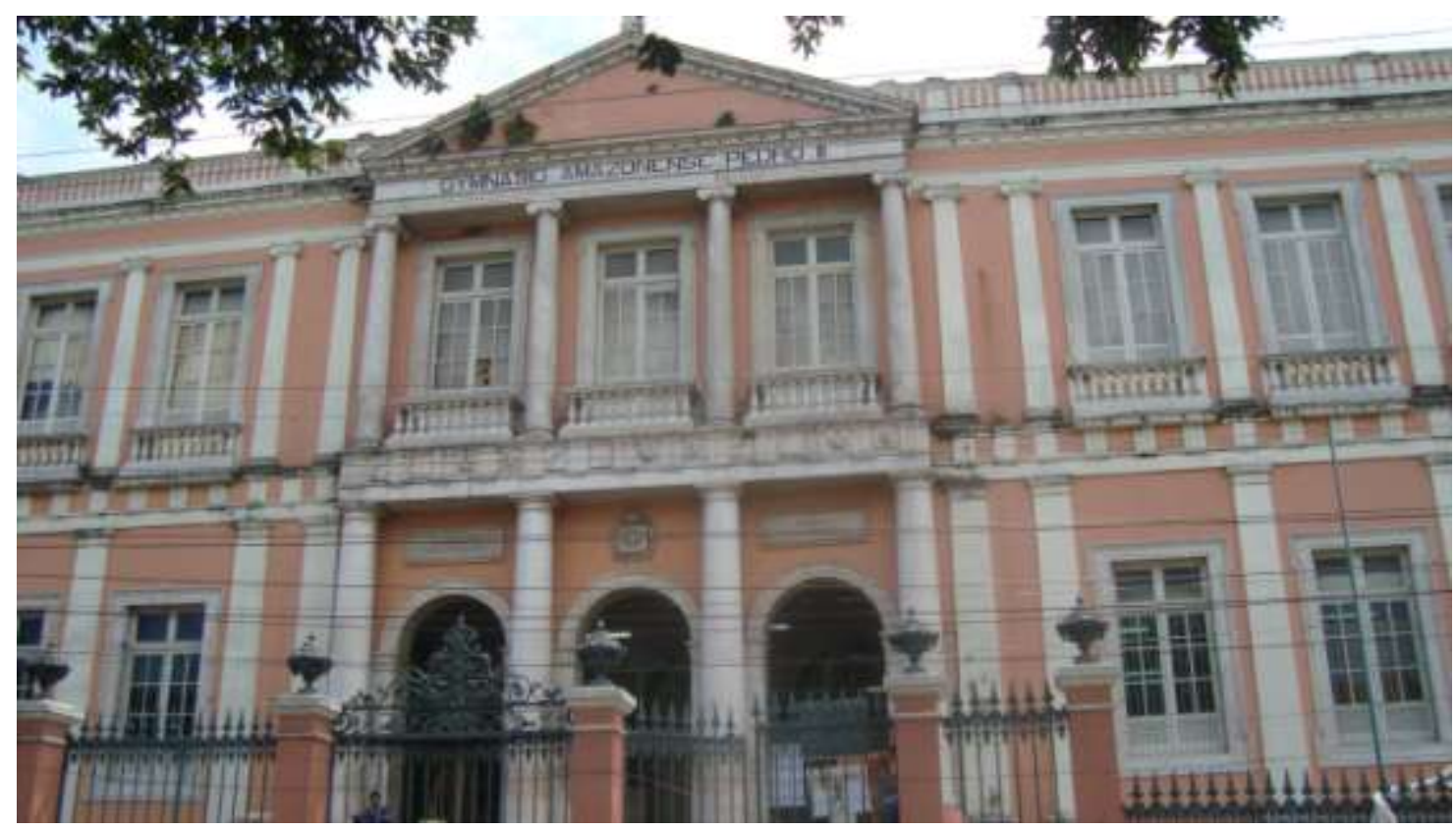


No Relato encontra-se a recolha dos estilhaços e ruínas de emoções identificáveis num inconsciente familiar. Nessas narrativas de "um certo oriente", a rememorização de imagens afetivas só é possível graças a estruturação da narração em base de uma polifonia de vozes narrativas familiares e diversos pontos de vista (BAKHTIN, 1984). Estas vozes se encontram enredadas nos fantasmas incertos da memória manauara.

No mesmo sentido, Hatoum afirma em entrevista (2010):

A literatura fala basicamente da passagem do tempo, filtra uma experiência do autor, que é transferida para o narrador. Nem tudo que a gente viveu cabe na literatura, então você tem que filtrar essa experiência e dar sentido a ela. Dar sentido com coerência interna, com uma estrutura bem armada. Isso é que é difícil, porque você julga um livro não pelo que o autor é ou pelo que ele fez ou faz ou diz, e sim pela linguagem. Agora, é claro que alguma coisa de mim, da minha vida, está presente nos meus romances e nos contos.

Hatoum conseguiu traçar sua própria voz com a construção literária assentada nessas memórias familiares:

Tenho parentes no Líbano, país que visitei com meu pai em 1992 e que ele não visitava havia mais de 30 anos. Então foi uma viagem muito emocionante porque eu conheci o país dele; conheci muitos parentes, primos, tios. (...) Os libaneses têm várias origens étnicas, e nisso se parecem com os brasileiros. (...) O Líbano é um pequeno recorte do Mediterrâneo com muita área verde, montanhas, e sem região desértica. O clima é maravilhoso, pois combina a temperatura à beira-mar (Mediterrâneo) com um clima mais temperado das montanhas (HATOUM, 2010).

Miltom Hatoum, em uma entrevista concedida à Professora Aida Hanania, conta que:

No Relato há um tom de confissão, é um texto de memória sem ser memorialístico, sem ser autobiográfico; há como é natural, elementos de minha vida e da vida familiar. Porque minha intenção, do ponto de vista da escritura, é ligar a história pessoal à história familiar: este é o meu projeto. Num certo momento de nossa vida, nossa história é também a história de nossa família e a de nosso país (com todas as limitações e delimitações que essa história suscite). (...). Além disso, as outras lembranças da infância, os relatos dos mais velhos. 
No Relato, a família está construída ao redor da matriarca Emilie e de seu esposo inominável. O casal possui quatro filhos, sendo Hakim o mais velho e uma das vozes mais relevantes na narração; há os dois filhos que, como o pai, são inomináveis e, por fim, Samara Délia, mãe solteira, e sua filha. Além dos filhos biológicos, o casal possui um casal de filhos adotivos, sendo a filha, a relatora principal do livro e o irmão, seu interlocutor. Como afirmou Milton Hatoum em várias entrevistas, ele construiu os personagens do Relato a partir de suas histórias pessoais com sua família, seus amigos e seus conhecidos. Sabe-se que a família de Milton, líbano-brasileira, foi constituída de um matrimônio entre uma manauara descendente de libaneses católicos e um libanês muçulmano imigrante. $\mathrm{O}$ autor narra esta melancolia da vivência entre duas línguas, duas culturas (a libanesa e a manaura) e duas religiosidades (católica e islâmica). Nesse sentido, esta situação aproxima do estado psicológico do duplo de Jung (1984) como aquel projeção do sujeito do eu dual que se vê, a si mesmo, como Outro, como entidade autônoma, mas idêntica ou semelhante em todos os aspectos. É o rival ou o complemento da personalidade. É um ser cindido em dois, do encontro do outro- o estrangeiro íntimo que habita o homem- ganha ressonâncias trágicas e fatais.

Figura 5: Estrutura genealógica da família-núcleo do Relato de um certo oriente (REZENDE, 2010, p.25).

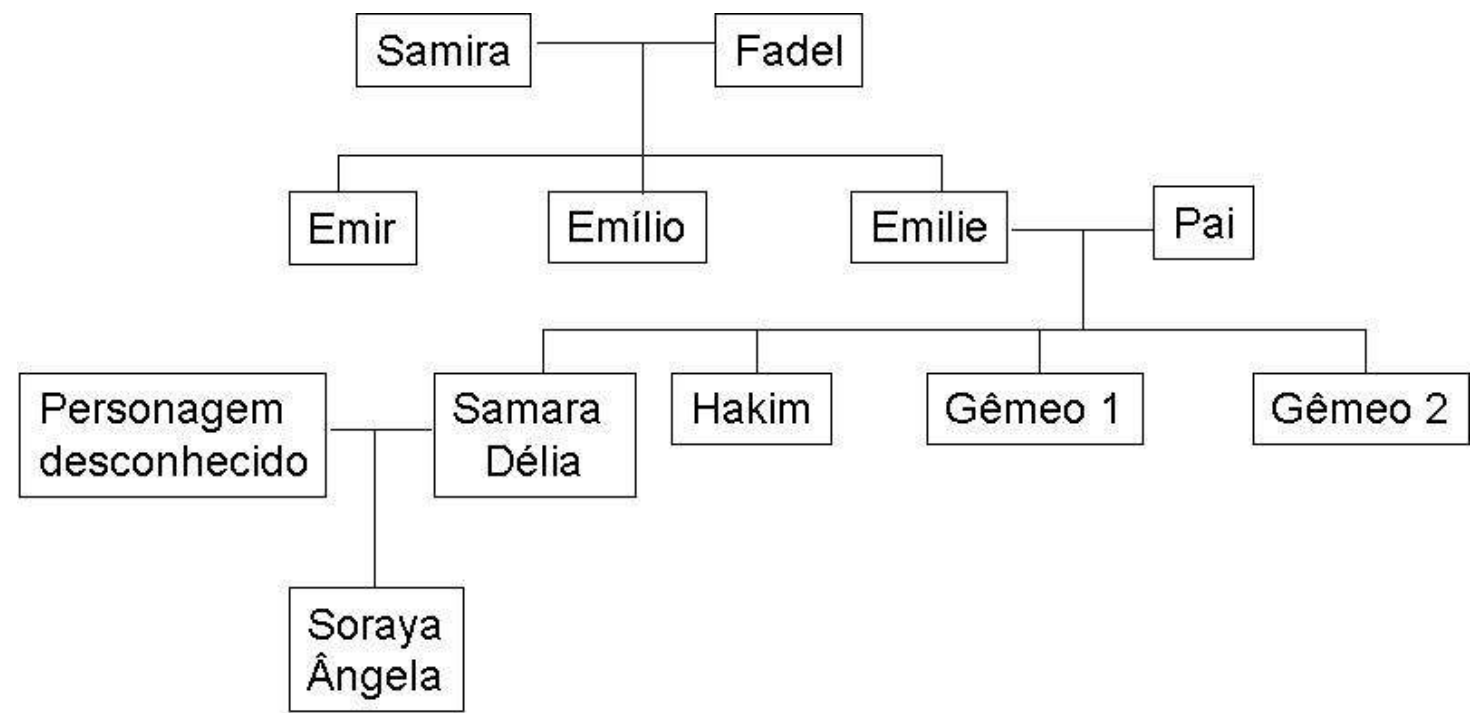


Após a publicação do Relato, Hatoum revisita várias vezes, vozes e situações familiares. Temos os seguintes exemplos:

Em Dois Irmãos (2000) aborda a relação entre dois irmãos gêmeos, Yaqub e Omar, e suas relações com a mãe, o pai e a irmã, numa família de origem libanesa que vive em Manaus. Moram na mesma casa Domingas, empregada da família, e o filho dela (o narrador). O amor doentio da mãe (Zana) pelo filho mais novo (Omar) tem muito de incesto, ignorando a relação com o próprio marido.

A narradora do conto "A natureza ri da cultura" é a mesma do Relato de um certo oriente, na mesma situação de rotorno a casa da avó Emilie. A narradora fala sobre Armand Verne, um dos amigos da sua avó, "um andarilho que colecionava lendas e mitos da Amazônia. Um homem que se apropriava da cultura dos nativos para salvá-los" (p.100) e, ao referir-se à plaqueta escrita por Delatour, outro estrangeiro amigo da família, intitulada "Voyage sans fin", dá bem a significação do personagem-viajante.

No conto "O adeus do comandante", narra sobre o seu Moamede, um homem que gosta de contar histórias, um vendedor de mercadorias, que são transportadas pelo rio Amazonas. Hatoum não escreve, mas fica claro que Moamede é um árabe, ou descendente de árabes. Numa entrevista, Hatoum nos contou que "seu Moamede é uma homenagem ao meu avô Mamede, que foi um grande contador de histórias". Hatoum afirma que as histórias que ouviu, na infância, sobre o Líbano, país de origem da sua família, ajudaram a estimular a sua imaginação. Muitas delas eram contadas pelo avô Mamede. "Ele contava histórias para os netos, e muitas me impressionaram", afirma. O conto, além de homenagem ao avô, é dedicado a um tio de Hatoum, Adib M. Assi. "Uma das pessoas que mais me estimularam quando comecei a escrever. Ele lê tudo o que publico", nos afirmou Hatoum. Ao respeito disso, Antonaccio (1996) conta:

Com a morte de Mamed Ali Assi, em 1968, a empresa se desmembra antes propriedade Mamed Ali Assi deixou 7 filhos: Tufic Assi, engenheiro; Munir Assi, empresário; Adel Assi, político; Samir Assi, economista e atleta; Adib Assi (sem dados) e as irmãs Naha e Nohad Assi, que deram continuidade com a loja, dentre estes filhos está a mãe do escritor Milton Hatoum, a filha Naha Assi Hatoum casou-se com o comerciante (regatão) Hassan Ibrahim Hatoum, pai do escritor. (ANTONACCIO, 1996, p. 238). 


\subsection{Retornar e relembrar}

Na sua reportagem no jornal $O$ Público, Susana Moreira (2012) revela um elo entre a escrita do Relato de um certo oriente e o retorno de Hatoum à cidade de Manaus:

Quando voltou para Manaus em 1984, o paraíso da sua infância tinha desaparecido. Tinha começado a construção frenética da especulação imobiliária - e em Manaus, diz Milton Hatoum, foi como um "terramoto". As histórias, essas, eram mais difíceis de destruir e seria nessas histórias que a Manaus da sua infância poderia reaparecer. Talvez essa ameaça de extinção tenha ajudado à força de Relato de Um Certo Oriente. Hatoum tinha encontrado uma voz feminina que ia tecendo um fio onde encaixavam, como contas num colar, as vozes e vários relatos. Era essa voz feminina que resolvia o quebra-cabeça. Quando deu por si, Milton Hatoum estava a escrever uma espécie de mil e uma noites em Manaus. A narradora era uma Xerazade, "não ameaçada de morte", explica Hatoum, "mas ameaçada de perda da memória". E assim começava a luta de Hatoum contra os bulldozers.

Silva (2008) assinala que a família também não escapará das incertezas provocadas pela chegada dos tempos do Fim do Ciclo da Borracha, e destaca:

Algumas (famílias), que ainda viviam dos restos da ostentação do antigo Ciclo da Borracha, ao final, são humilhadas pela leva de novos-ricos. No Relato, uma família de árabes imigrantes amplia em Manaus uma riqueza trazida do Líbano, inclusive de cheiros e sabores, que se misturariam aos da Amazônia.

Com respeito à relatora hatoumiana sobre a cidade de Manaus nesse período, Borges (2009) conta:

Essa narradora assume a posição de observadora dos fatos como uma testemunha privilegiada, por meio de um mergulho na memória para que os fatos venham à tona em seu relato, e assim nos contar as transformações da Manaus - que viveu as glórias da belle époque - em Cidade Flutuante - tendo como símbolo as casas de palafitas recendendo a lodo.

Temos os personagens hatoumianos sempre às voltas com lembranças passadas, na tentativa de reconstruir algo perdido no tempo e tragado pelas próprias vivências e experiências cotidianas. O herói "não se dispõe a enfrentar a antinomia eu - mundo pela ação". Nessa impossibilidade, busca outros caminhos para resolver os seus conflitos. O que se observa na tentativa de reconstrução da vida de Nael, em Dois irmãos, ou na relatora-personagem de Relato 
de um certo Oriente que, ao retornar a casa, depois de uma longa ausência, tenta emendar os fios soltos de sua vida. Essa ausência pode produzir polifonia de sentidos a partir desses silêncios subjetivos: "Na fala da mulher que permanecera diante de mim, havia uma parte da vida passada, um inferno de lembranças, um mundo paralisado à espera de movimento.” (HATOUM, 2004, p. 11).

No Relato, a narradora, ao relatar sua estada na clínica onde recebia tratamento psiquiátrico em São Paulo, descreve a cena a partir desse "olhar estrangeiro":

Da janela do quarto vi o emaranhado de torres cinzentas que sumiam e reapareciam, pensando que lá também (onde multidão se espreme em apartamentos ou em moradias construídas com tábuas e pedaços de cartão) era outro lugar de solidão e loucura. (HATOUM, 1989, p. 160).

Ao voltar à casa da infância e da juventude, na cidade de Manaus, o espaço social onde foi criada, a relatora vive um estado liminar de exílio, ou seja, um sofrimento pela ausência por longo tempo do seu lar. Aqui vem o ato traduzir a memória numa escrita legível como forma de cura (SAFATLE, 2011), como descreve a narradora, traduzida por Hatoum no Relato:

Havia momentos, no entanto, em que me olhavam com insistência: sentia um pouco de temor e estranheza, e embora um abismo me separasse daquele mundo, a estranheza era mútua, assim como a ameaça e o medo. E eu não queria ser uma estranha, tendo nascido e vivido aqui. (p.123)

Também, com narrativas de enredos cíclicos e com predominância do discurso indireto livre, Hatoum volta ao tema em Cinzas do Norte, com o retorno do narrador Lavo a Manaus, lá rememora passagens de sua vida ao lado dos tios Ran (Ranulfo) e Mira (Ramira).

No conto "Uma estrangeira da nossa rua", é o mesmo personagem (Lavo) que, ao retornar de São Paulo à sua cidade, encontra a casa azul, o bangalô que ficava defronte a do seu tio, em ruínas. Lembra-se da inglesinha Lyris e sua família estrangeira, os Doherty, que "vivia em outro mundo". Reaparece o seu tio, com as mesmas características de solteirão conquistador, "apenas mais tosco e bruto, andava nu pela casa”, e, Mira, sua tia, dona de casa sempre à espera. Ao rememorar a paixão de sua juventude por Lyris, o narrador conclui que o fracasso no amor "não é atributo apenas da juventude", como a registrar que em sua trajetória à maturidade continua a experimentar dissabores no plano sentimental. (p. 22). 
Também, Professora Aíla Sampaio (2010) ressalta o tema do retorno no conto "Dois tempos":

O narrador (Lavo) narra seu retorno a Manaus, seu encontro com a amiga Aiana que o interpela para perguntar se lembra da sua infância da professora Tarazibula Steinway. Ele recorda as aulas de piano que frequentavam juntos, há muitos anos e o concerto a que assistiu, junto com o tio: a plateia quase vazia, mas a pianista tocando gloriosa. Volta à realidade quando, levado pela amiga, se vê no velório da professora, onde encontra desolado, o seu tio Ran.

Elias dos Santos Silva (2005) observa o mesmo tema em Lavoura Arcaica (1973):

Raduan Nassaer mantém bem marcado o tema do retorno com a volta de André para casa como um conquistador prestes a desferir um golpe de Estado. (...) $\mathrm{Na}$ festa feita em homenagem a André, sua irmã dança, sensual, lasciva e cônscia de que seu amor sujo vai ter continuidade. Macho e fêmea já estão prontos para criar e procriar uma família da Nova Ordem. (...) Iohana sente que seu mundo está sendo periculosamente ameaçado. Ao fazer verter o sangue de Ana, porém, Iohana está na verdade completando o desmoronamento do seu próprio mundo. O Pai/Ditador não venceu suprimindo brutalmente um dos elementos originadores do desequilíbrio, pois a morte de Ana é do ponto de vista da tradição alimentada pelo próprio Iohana, mais grave e perturbadora que $o$ incesto. Assim, o gesto fatal apenas precipitou a vitória da Nova Ordem.

Seguindo Giambattista Vico (1668-1744), Said (2007) aponta a uma mobilidade, que vai como num eterno retorno a um tipo de "poética de persistência na memória" e de resistência e ao esquecimento.

\subsubsection{Hakim, o duplo}

A memória é o local das pressões que sofrem os descendentes de libaneses (personagens de Hatoum com Hakim no Relato e Mundo em Cinzas do Norte ou o caso de André em Lavoura Arcaica de Raduan Nassar). Eles vivem uma vida dupla entre a cultura de famílias árabes reunidas muitas vezes ao redor de clubes tradicionais, organizações sociais de caridade, as mesquitas, as igrejas e entre a cultura da sociedade na qual recebem a sua educação e estabelecem as suas amizades e envolvem-se suas vidas profissionais. Esta vida dupla entre os valores das tradições culturais "patriarcais" árabes e os valores liberais resultou em uma tensão na formação cultural dos descendentes, que revela conflito social entre as gerações antigas, que tentam preservar as tradições sociais e religiosas, e as gerações novas. 
O autor, mascarado no personagem Hakim, aborda no Relato (2007) esta dualidade cultural, descrevendo sua vida entre a sociedade na escola e nas ruas e a comunidade na loja dos pais, a Parisiense: "Desde pequeno convivi com um idioma na escola e nas ruas da cidade, e com um outro na Parisiense. E às vezes tinha a impressão de viver vidas distintas.” p. 52. Os membros da família, que conviviam com uma cultura dentro de casa e outra fora se encontram obrigados a saber conciliar essa duplicidade, como no trecho citado.

\subsubsection{Monólogo dialogante de Hakim}

O aspecto biográfico híbrido e o literário de Milton Hatoum se manifestam também no silêncio e nas reflexões de Hakim, ao dizer: "Aquele silêncio insinuava tanta coisa, e nos incomodava tanto... Como se para revelar algo fosse necessário silenciar" p.92. O descendente vive experiências de familiarização do exótico e exotização do familiar. Hakim vive um exílio psicológico, por isso ele constrói a memória familiar através de um "monólogo dialogante", ou mono-diálogo, a expressão de Rama, ou seja, diálogo intímo na mente do personagem com os objetos guardados do passado de sua mãe Emilie, fazendo de si mesmo seu próprio interlocutor (FRANCISCO, 2007):

A leitura da caligrafia minúscula foi um trabalho maçante para mim. Escrita em árabe clássico, e sempre assinada por V.B., a correspondência atravessava anos e anos, às vezes interrompida em intervalos de meses. Nessas zonas de silêncio, eu perdia o fio da meada e enfrentava dificuldades com a escrita, saltando frases inteiras e vituperando contra os vocábulos, como um leitor encurralado por signos indecifráveis. A descontinuidade da correspondência e a incompreensão de tantas frases me permitiam apenas tatear zonas opacas de um monólogo, ou nem isso: uma meia voz, uma escrita embaçada, que produzia um leitor hesitante. As passagens mais obscuras das cartas foram decifradas com o auxílio da intuição: um recurso possível para sair do impasse da leitura pontilhada de titubeios, sem o auxílio de um dicionário, embora folheasse a torto e a direito os cadernos de anotações que Emilie guardara junto às cartas (...). P 56

Hakim vai acompanhando esse silêncio como na "Evocação do Recife" de Manuel Bandeira (1967), isto é, como processo de tradução da memória infantil em linguagem a partir de recordações de cores e cheiros inesquecíveis da infância:

Sob a copa da árvore, passei a mirar as flores rosadas que cobriam os galhos, as frutas arroxadas que apodreciam na grama, e sentia falta do odor do jasmim 
branco, que os adultos chamam de Saman, o perfume de um outro tempo, a infância (P 122)

\subsubsection{Hakim e a língua árabe}

A aprendizagem de Hakim nos remete a um processo psicológico indicado por Le Goff como aquisição da memória, num processo social assinalado por Florestan Fernandes (1975) como aburguesamento. A memória envolve a releitura das poéticas dos vestígios mnemônicos da sociabilidade. Essa memória cultural assegura a reprodução dos comportamentos na sociedade, e gana maior importância nas sociedades sem escrita. Nessas sociedades há homens-memória, que representam a memória coletiva. Neste sentido, Hatoum - Hakim podem ser considerados homens-memória. Hatoum e Hakim são mnemons, guardiões de memória coletiva (LE GOFF, 1992). Hakim, protagonista e narrador privilegiado, constituiu sua posição de herdeiro da vida familiar e testemunha da imigração por meio da busca incansável dos segredos que Emilie guardava. Ele também ocupa um lugar central na reconstrucção de uma noite de Natal. No Relato, há um continuum entre o vivido e o lido, o fabulado e o lembrado. O Relato dialoga com o silêncio, por isso se situa entre a memória e a morte (KANZEPOLSKY, 2008). 


\subsection{Deslocamento/ exílio}

"O tempo passado está morto como tempo, mas não como espaço."

\section{Milton Santos}

Figura 6: Multiverso de Milton Hatoum, Maged El Gebaly, 2012.

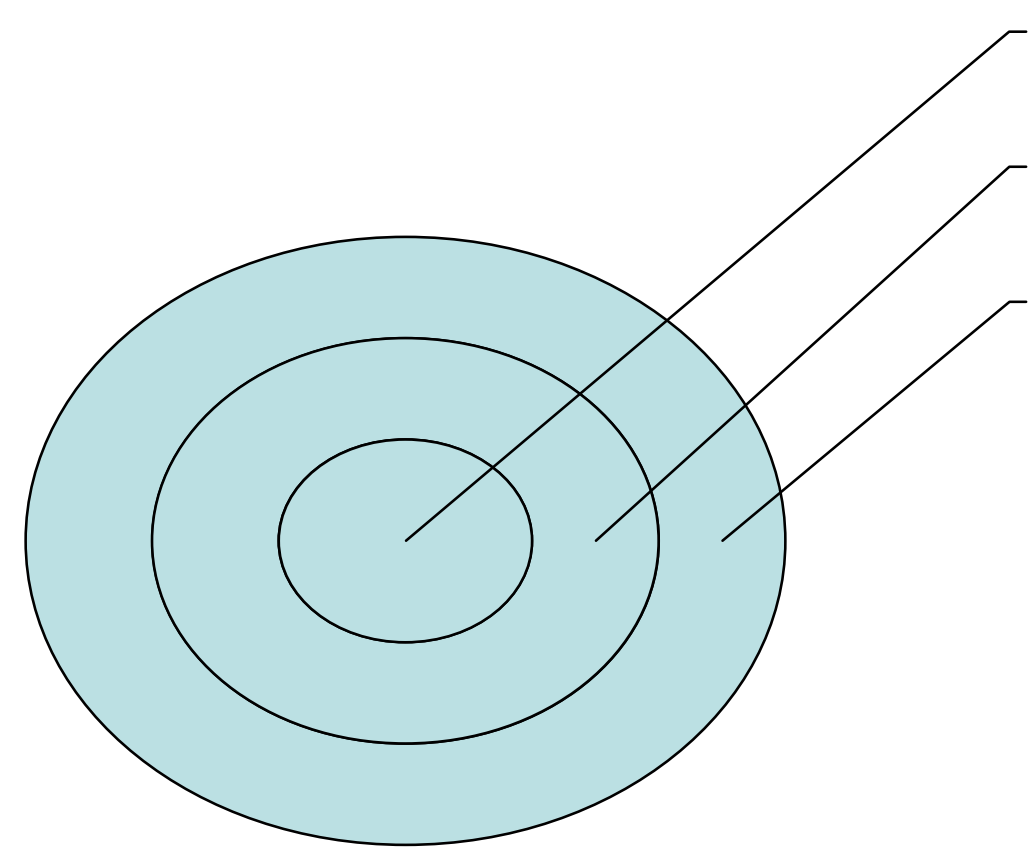

Casa/

Parisiense

Manaus e

outras cidades

Multiverso

hatoumiano

$\mathrm{Na}$ sua construção memorialística, Hatoum reinventa vozes fragilizadas por esses deslocamentos. A relatora começa a rememorizar lembranças de quando era criança num evento familiar: o Natal de 1954. A memória no Relato parece uma junção frágil de fragmentos, processo que mimetiza as sendas imprecisas da memória afetiva de Hatoum, evocando espaços de Manaus como o Centro Cultural do Palácio do Rio Negro, cujas decorações dialogam como as descrições da Casa da família de Emilie no Relato. Como conta Hatoum: 
A memória é o único desafio ao passado, de prestar contas com ele, seja através de uma imagem, de uma história oral ou escrita. É como se, diante de uma ruína, a gente tentasse imaginar a casa antes de sua demolição ou destruição: quem morava ali, como e em que tempo viveram aquelas pessoas, como elas se relacionavam entre si, etc (HATOUM, 2003, 62).

No Relato, a casa não é somente símbolo dos vínculos familiar, mas também o espaço memorialístico das perdas emocionais. Maria Zilda Cury (2003) assinala que

No Relato, a casa libanesa, reconstruída pela memória, expande-se, ergue-se como espaço da terra natal indissociado dos ares e flora tropicais, como "oca aérea" (...) Mulher e casa se mesclam no mesmo corpo, no mesmo centro, fixadas na fotografia.

Ao lado da casa, a Parisiense não representa somente uma loja libanesa de trocas comerciais, mas é o espaço marcado pelas de trocas culturais e sociais. Com relação a Parisiense, Antonaccio destaca (1996, p. 237):

Era um dever ou uma obrigação das noivas de Manaus, antes de encomendar o seu vestido de núpcias a uma famosa loja estabelecida na Avenida 7 de setembro, esquina com a Eduardo Ribeiro, que tinha como nome de fantasia Esquina das Sedas e viera para substituir a primeira casa comercial do Sr. Mamed, a loja estabelecida na Av. Joaquim Nabuco denominada A Parisiense.

O fio do enredo do Relato vai circulando pela casa, passando por cenas do Rio Negro, do Manaus Harbour, da Alfândega, da Igreja da Praça Nossa Senhora dos Remédios dos imigrantes libaneses maronitas, da Praça da Polícia, do Bairro de Educandos, do Interior do Amazonas, outras referências de Oriente Médio como Teerã no Irã, e cidades libanesas como Beirute, Trípoli, Ebrin e Monte Líbano, e alusões a espaços mediterrâneos como Chipre, Tristie na Itália, Marselha, Leon, Pirineu, na França, Minio e Bovoa de Varzim em Portugal. Também, evoca a Praça do Diamante em Barcelona na Espanha como um entre-lugar a que se colam Manaus e a cidade imaginária da infância (CURY, 2009). 
Figura 7: Rio Negro (Maged El Gebaly, Manaus 16/05/2012)

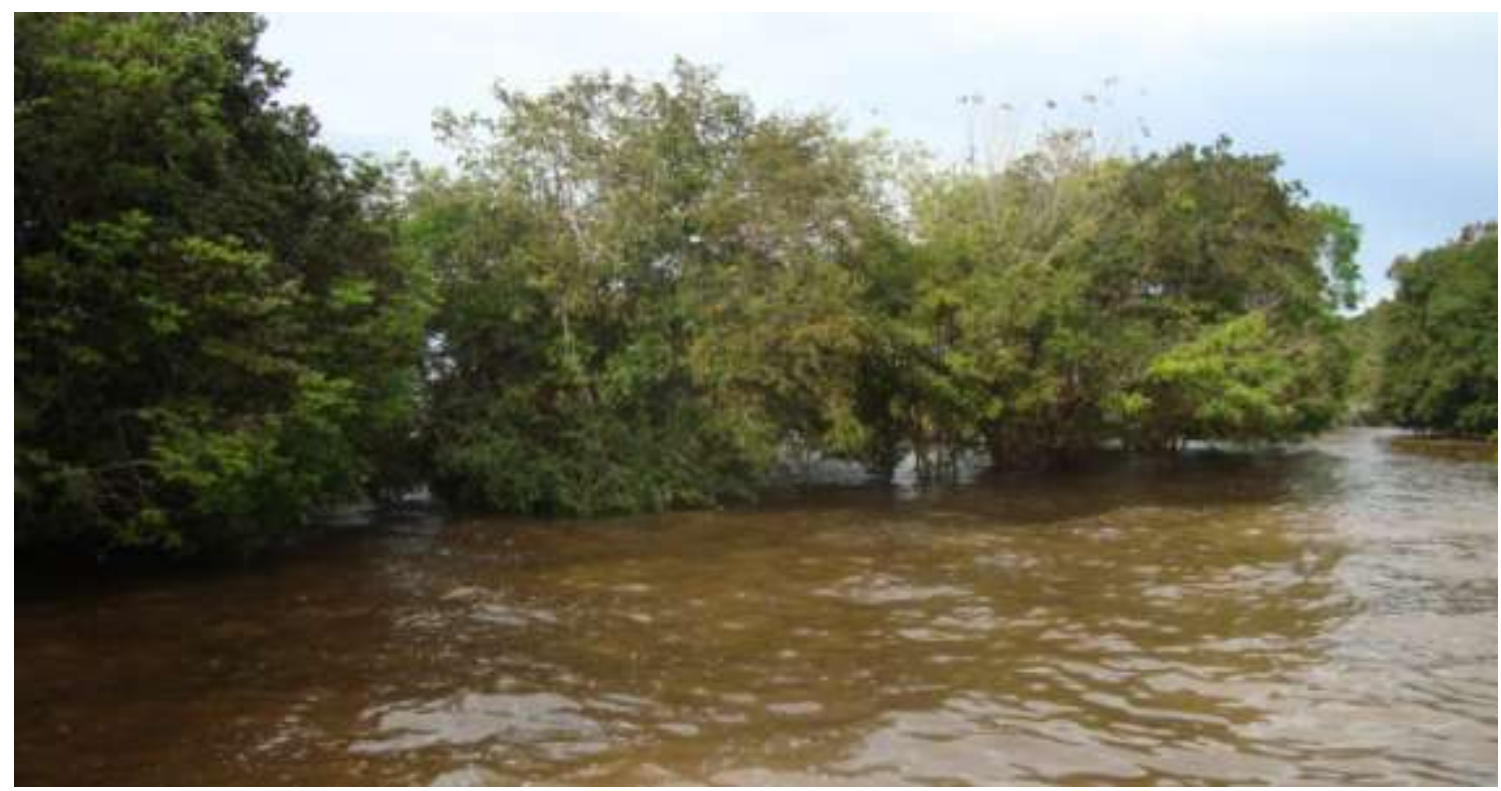

Figura 8: Igreja Nossa Senhora dos Remédios (Maged El Gebaly, Manaus, 16/05/2012)

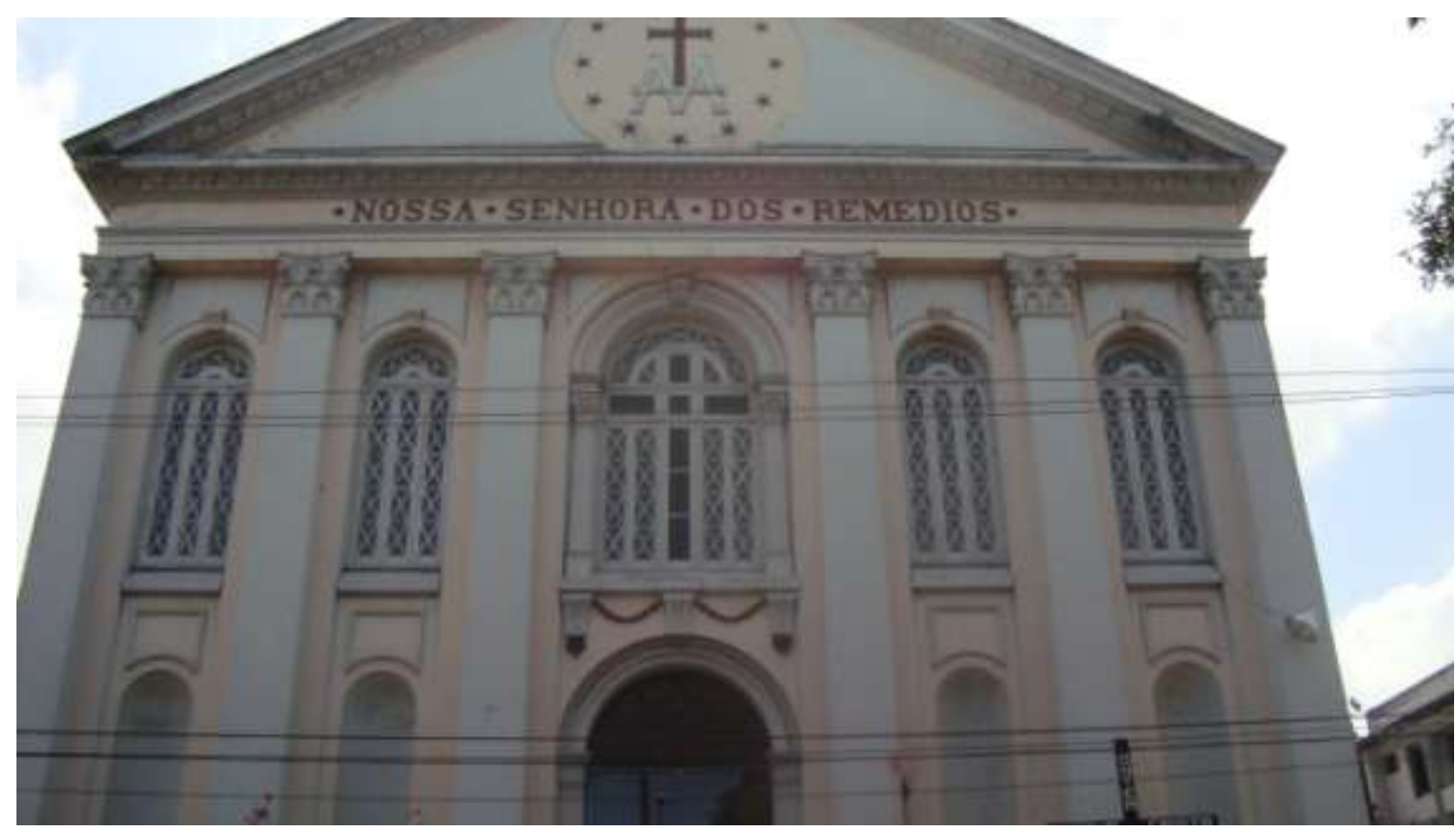


Figura 9: O Porto de Manaus (Maged El Gebaly, Manaus, 16/05/2012)

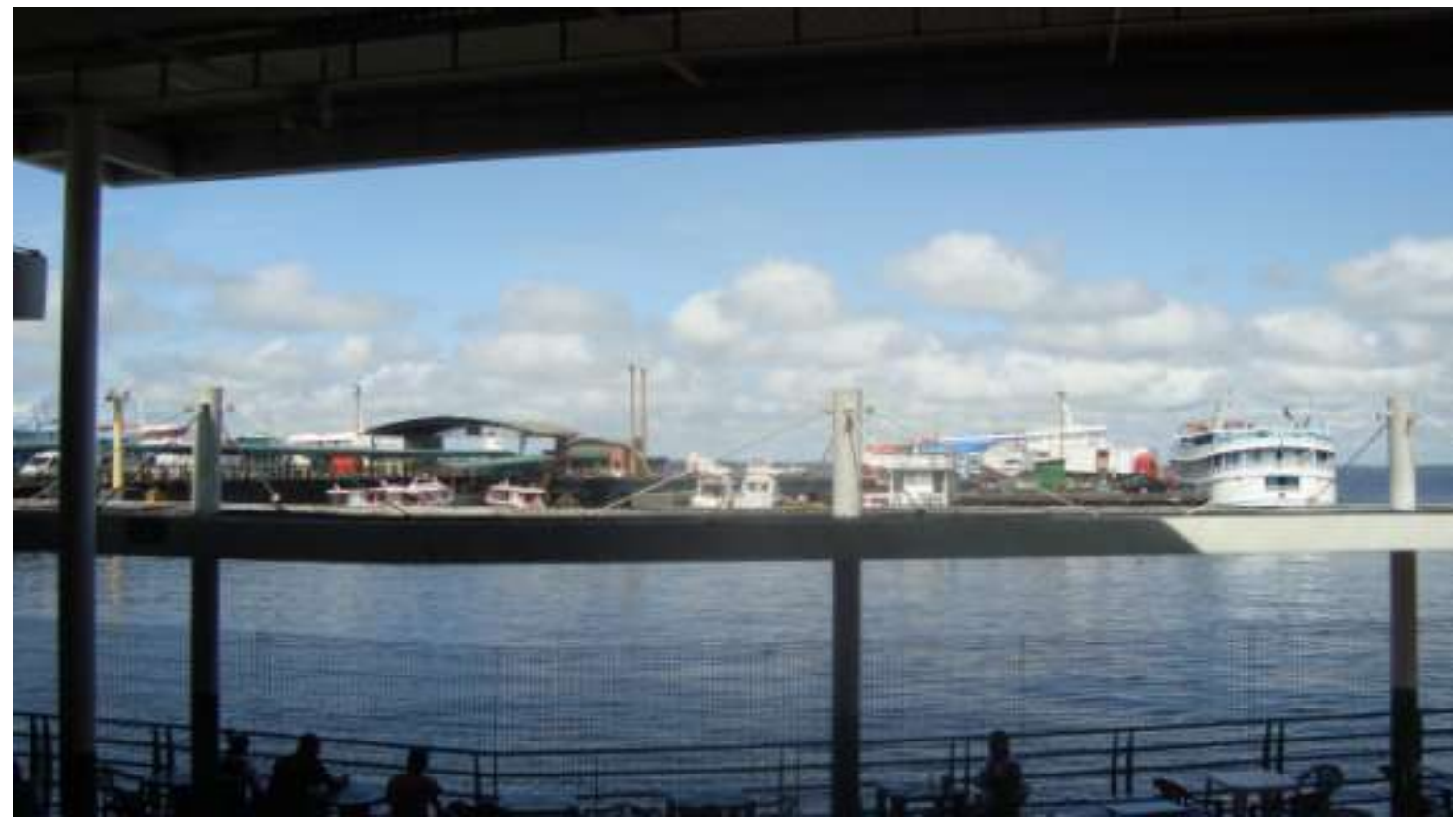

Figura 10: Alfândega de Manaus (Maged El Gebaly, Manaus, 16/05/2012)

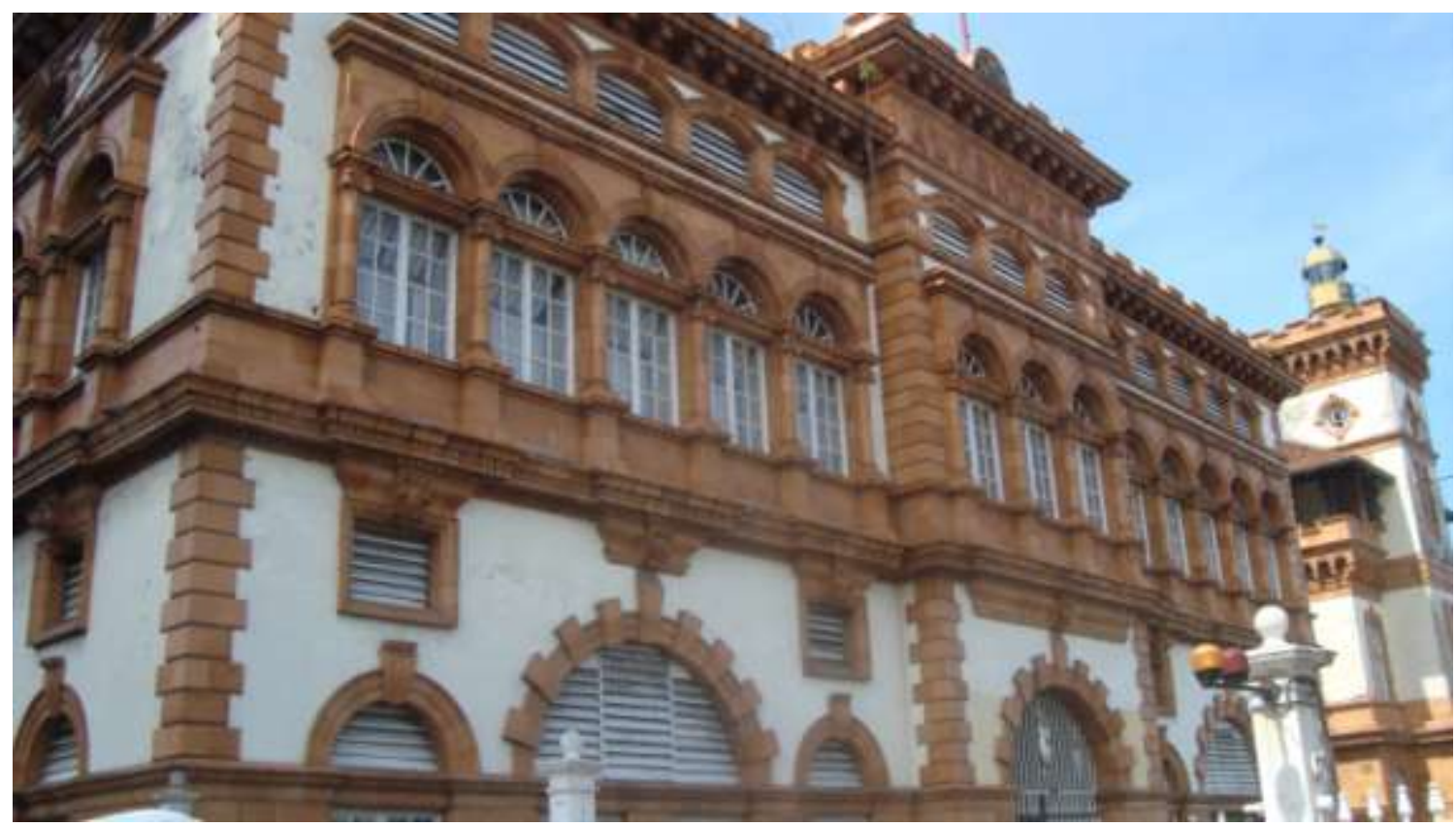




\subsubsection{A Casa}

O visitante de Manaus nota a relevância das caserões e das lindas casas decadentes que marcam a memória coletiva visual dos manauras. Na nossa visita ao Centro Cultural do Rio Negro observamos muitas das descrições da casa no Relato dialogam com a casa desse Centro.

Figura 11: Pagode no Palácio do Centro Cultural do Rio Negro (Maged El Gebaly, Manaus, 18/05/2012).

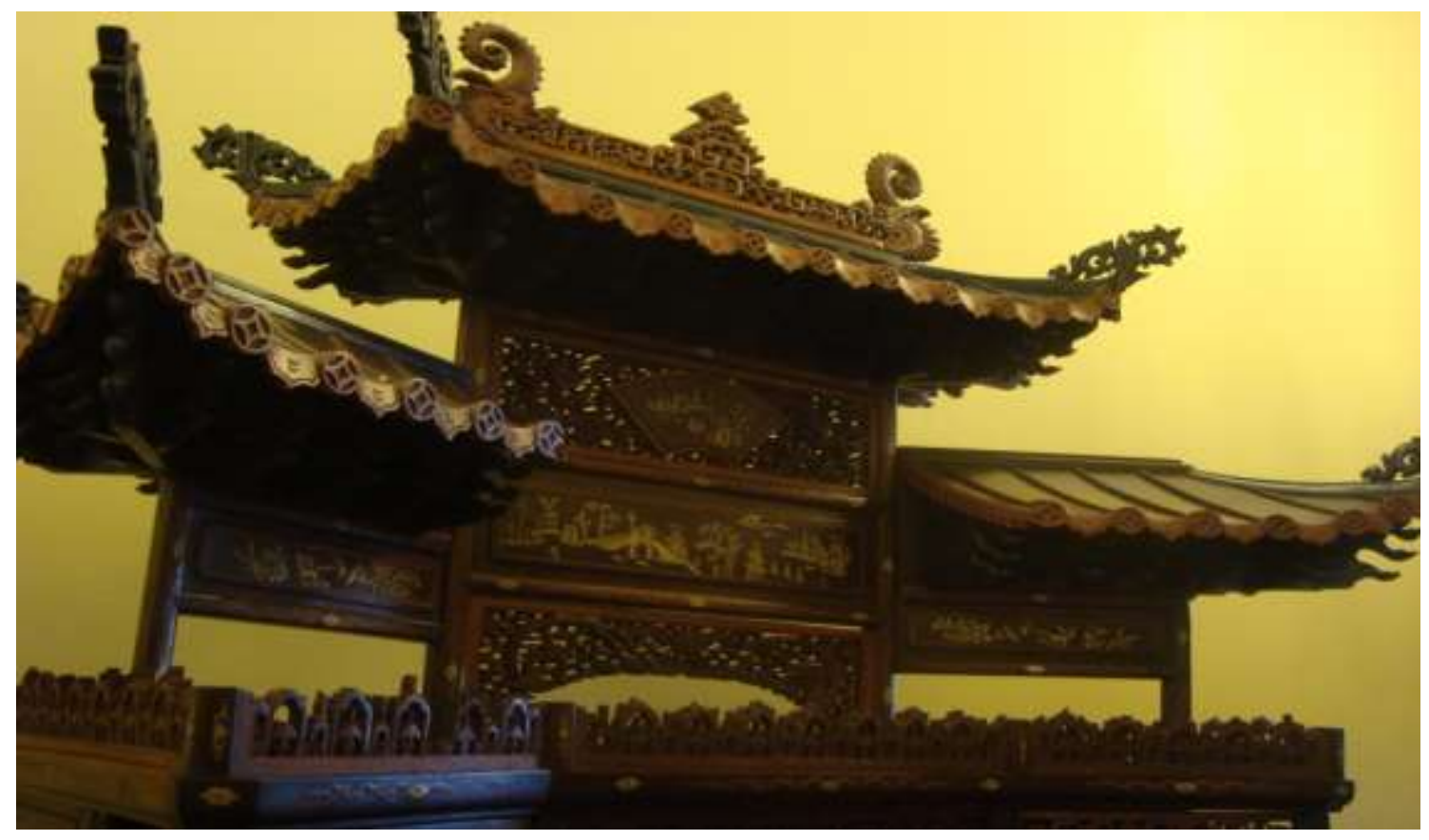


Figura 12: Pagode no Palácio do Centro Cultural do Rio Negro (Maged El Gebaly, Manaus, 18/05/2012).

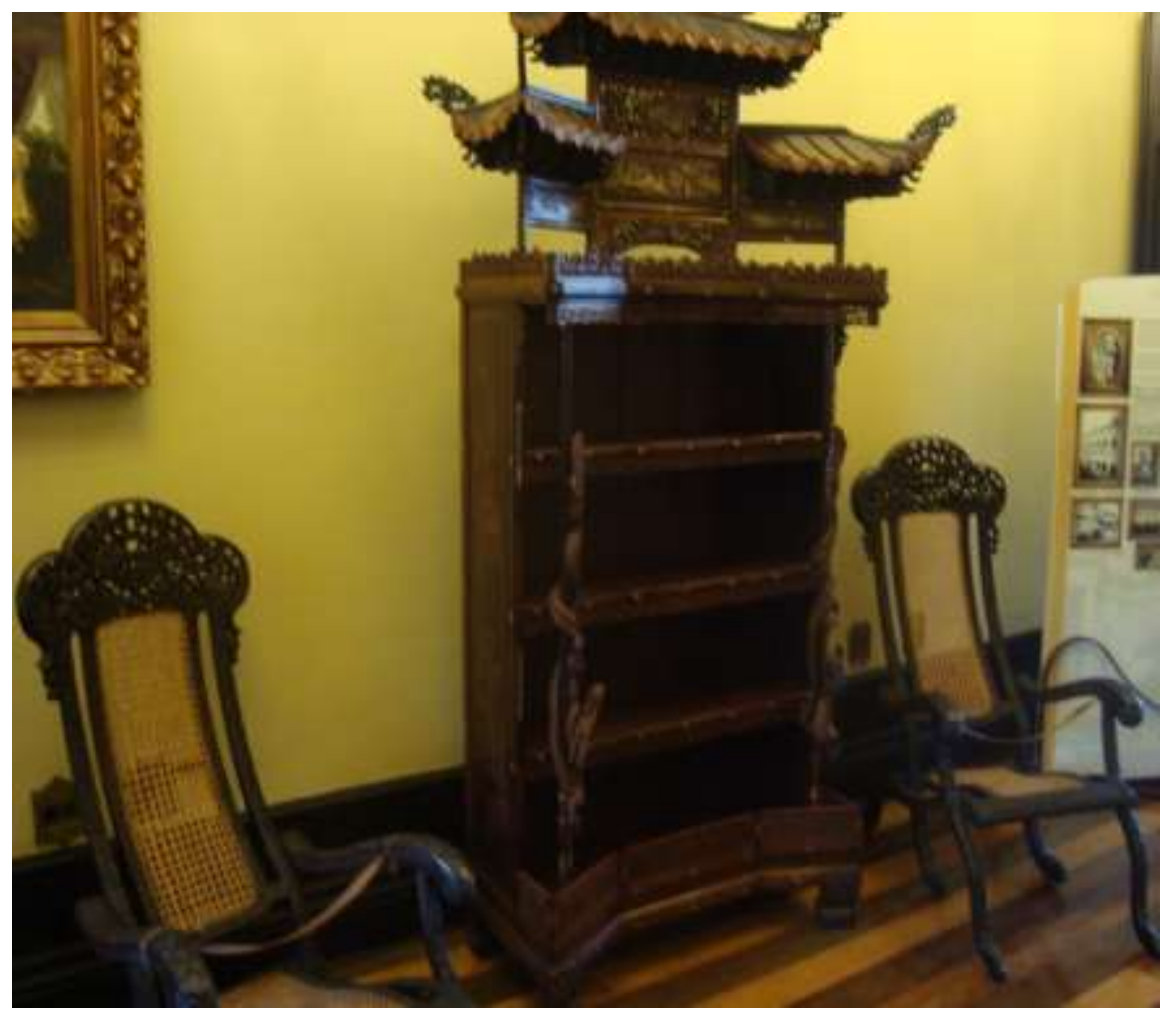


Figura 13: Uma claraboia no Palácio do Centro Cultural do Rio Negro (Maged El Gebaly, Manaus, $18 / 05 / 2012$ ).

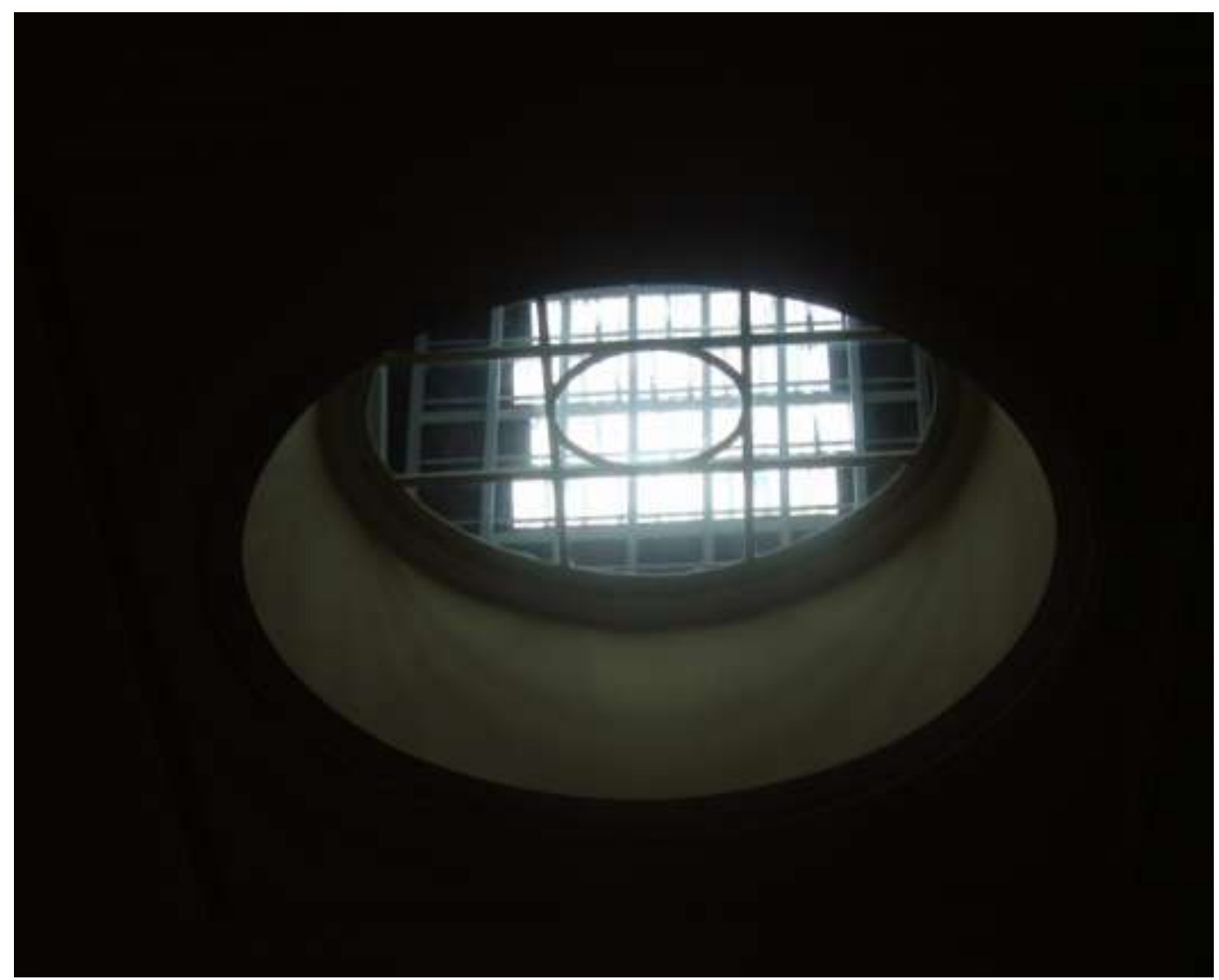


Figura 14: Fonte no Palácio do Centro Cultural do Rio Negro (Maged El Gebaly, Manaus. 18/05/2012).

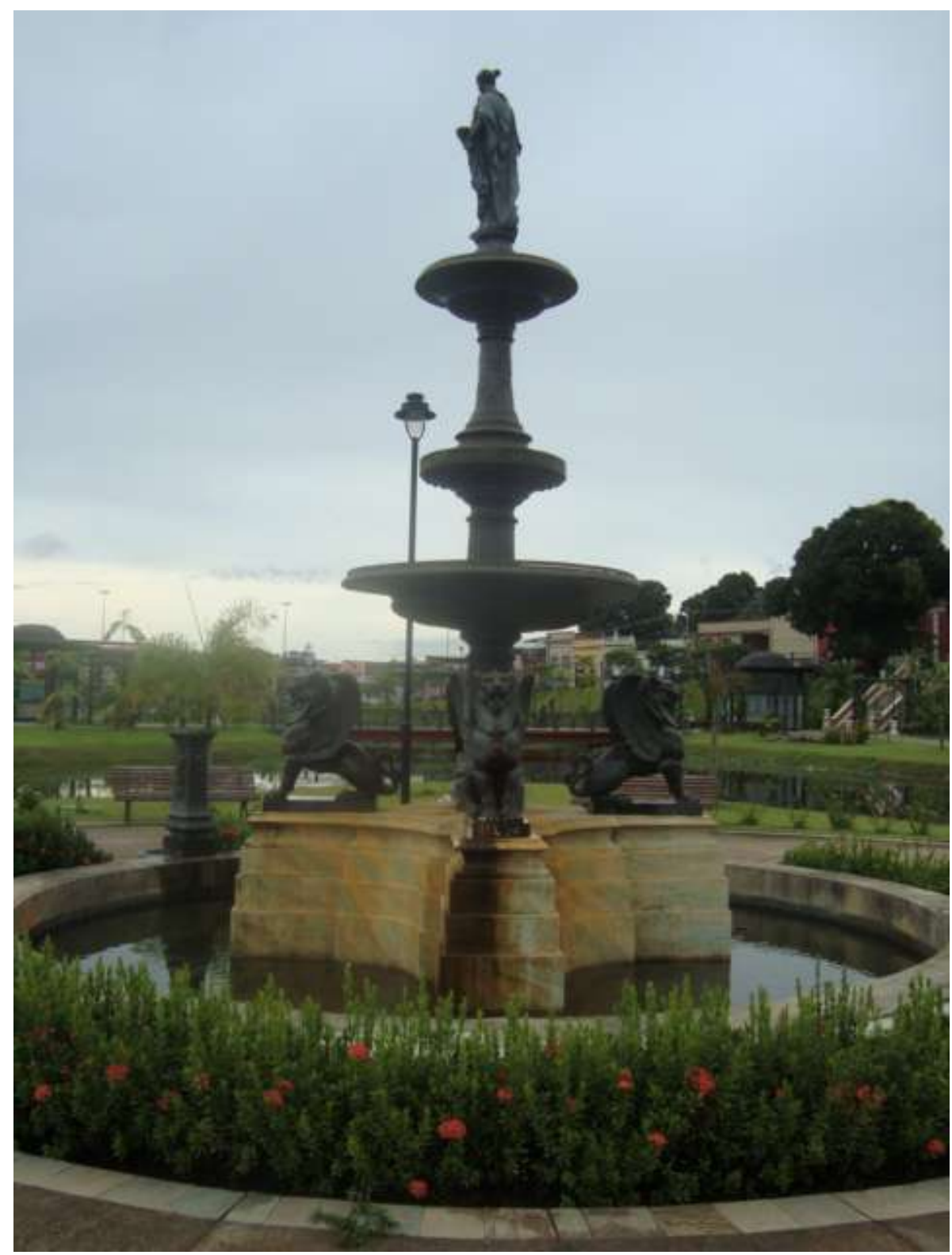

No Relato de um certo Oriente, a casa é um espaço vital para a interpretação social. Tratase de uma arquitetura imaginária que visa inventariar as perdas emocionais. Em Dois irmãos, a supremacia da casa como símbolo maior dos desajustes prevalece, mas é atenuada na mescla com o universo da cidade. De modo mais marcado, a casa agora se expande com a busca de lugares públicos e questões de cunho externo passam a interferir nas relações familiares, a exemplo do 
Ciclo da Borracha, do desembarque de imigrantes, dos anos de Ditadura Militar no Brasil ou da criação da Zona Franca de Manaus. (BACHELARD, 2008; MÜLLER, 2011)

Uma das características apontadas por Darcy Ribeiro (1999) em seu ensaio com relação às sociedades futuras será a superação da diferença entre cidade e campo (No Relato, Manaus versus Interior/Paris versus Marselha e Beirut) com o desenvolvimento tecnológico das estruturas agrícolas. Dessa forma, a "ciência torna-se, desse modo, o agente fundamental da ação humana sobre a natureza externa, sobre a ordem social e sobre a própria natureza humana".

Figura 15: Mapa do deslocamento no Relato de um certo oriente (DE ANDRADE, 2007).

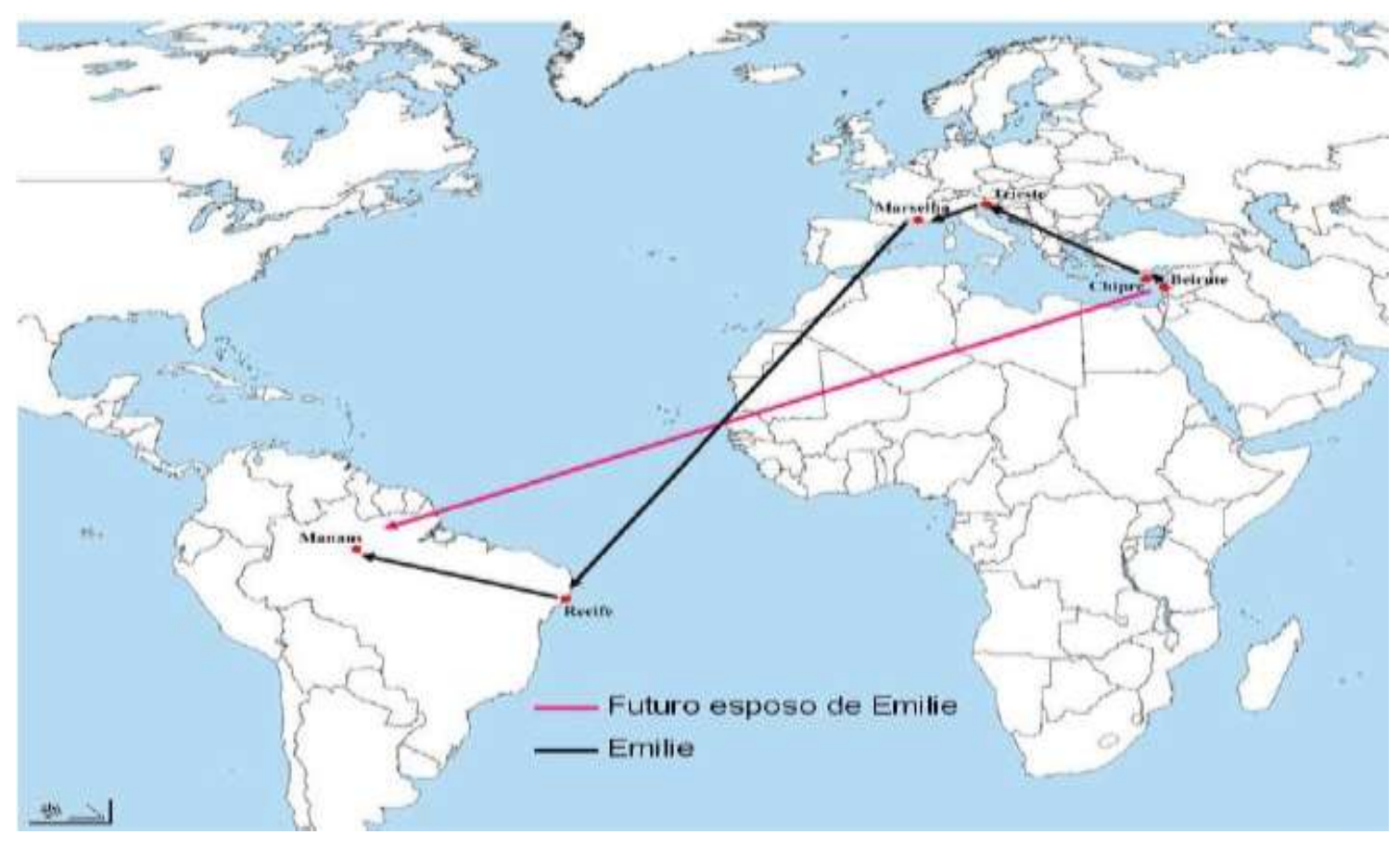


Em Cinzas do Norte, Hatoum volta ao tema das mudanças na vida dos personagens pela morte e pelo deslocamento:

Depois da morte de Jano, mãe e filho se mudam para o Rio de Janeiro. Pouco tempo depois, Mundo decide viver na Europa, mas sua vida lá não é fácil. No retorno ao Brasil, e já com a saúde debilitada, acaba por descobrir a verdadeira identidade de seu pai. Lavo continua a viver em Manaus. De um lado, Mundo, revoltado com a personalidade do pai - que não aceita a sua vocação artística sofre na infância e na juventude. Do outro, Lavo, ouvinte e confidente do amigo, acompanha de perto a sua trajetória. Juntos, constroem uma amizade. (SILVA, 2011)

O livro A Cidade Ilhada (2009) reúne uma série de contos que representam fotograficamente Manaus - a cidade ilhada em transição entre cidades ilhadas "pelos rios e pela floresta", personagens isolados comunicados com narradores e situações narrativas que dialogam com a vasta bagagem literária de Milton Hatoum, que trabalha esses fragmentos da memória até que adquiram outro caráter: frutos do acaso e da biografia pessoal, eles afinal se mostram como imagens exemplares do curso de nossos desejos e fracassos. Se o desejo, a literatura ou a viagem levam os personagens ilhados a expandir o raio de sua ação e a transpor as barreiras da infância e da moral, da classe e da província, estes mesmos elementos não se dão por vencidos e, mais cedo ou mais tarde, recaem sobre os heróis como uma fatalidade que os traz de volta a um centro imóvel: "para onde vou, Manaus me persegue".

O tema do deslocamento é um tópico repetitivo nas narrativas de memória da imigração como no romance Nur na escuridão (2004):

Nur na escuridão apresenta a "saga" do deslocamento de uma família de imigrantes libaneses, que resolve "fazer a América", buscando melhores condições de vida. Assim, através de um intrincado jogo memorialístico, que alterna fatos, tempos e lugares, a história dessa família é contada, desde sua saída da terra de origem e chegada ao Brasil até a morte do patriarca Youssef Miguel...A família de imigrantes é composta pelo pai, Youssef, a mãe, Tamina, seu irmão Hanna, que pouco tempo depois do desembarque decide fixar residência em Porto Alegre, e os sete filhos, entre eles: Salim, Fádua, Hend, Jorge, Sayde e Samir. O destino do grupo familiar será o comércio: primeiro mascateando e depois estabelecendo sua própria casa de comércio em 
cidadezinhas do interior de Santa Catarina, como São Pedro de Alcântara e Biguaçu. (SILVA, 2010).

Habitado por imigrantes, o universo ficcional de Milton Hatoum caracteriza-se pela apreensão de identidades fortemente marcadas pela condição do exílio. A escrita das memórias íntimas vira o entrelugar do exilado. O tema do exílio psicológico se repete muito na obra de Milton Hatoum. Said (2004) define o exílio como um sofrimento pela fragmentação incurável do ser humano que se separa do seu lar. No exílio toda a narrativa do triunfo que o homem produz serve como uma maneira de tentar superar este sofrimento. Segundo o crítico palestino, vivemos a era dos exilados que sentem uma necessidade de retomar suas vidas fragmentadas por estar fora da sua comunidade como foi o caso do filólogo alemão Erich Auerbach (1892-1957), exilado da Alemanha nazista para Istambul, onde escreveu sua Mimesis (1976). Segundo Said, o exílio cria uma solidariedade comunitária exagerada e acaba alimentando paradoxalmente o vínculo afetivo à sua procedência. $\mathrm{O}$ exilado começa a recriação do seu ser no novo entrelugar somente quando consegue reconstruir sua narrativa identitária, não a partir de supostas "origens" estáveis, mas da descontinuidade que caracteriza o exílio. Nesse sentido, o exilado desenvolve uma consciência dialogante para recriar uma subjetividade ativa e não sentir marginalizado.

\subsection{Narradores em trânsito}

A relatora principal inominável, máscara de Milton, é a filha adotiva de Emilie. (SURDI, 2008). Milton aborda na sua obra frequentemente o tema do personagem adotado porque permite tratar a experiência de uma marginalização cultural. Estamos diante de uma construção identitária que faz com que um sujeito liminar marginalizado seja colocado no centro narrativo.

Estruturalmente, os oito relatos que compõem o romance Relato de um certo oriente buscam completar as versões do outro e, mesmo assim, as descrições ainda são parciais, inexatas, mas evidenciam uma "reinscrição" (hibridização), ou rasura no relato anterior ou correspondente a um determinado fato. Esse aspecto estrutural da narrativa simboliza a dispersão de identidades fixas das personagens e dos relatos, perdendo-se, portanto, a noção de origem. Há, nessa relação, um trânsito não apenas de relatos, mas de "olhares" e, portanto, de identidades que se complementam. Assim, as próprias personagens em situações diaspóricas ou de dupla inscrição cultural, como a própria relatora, Emilie, Lobato e Anastácia chegam à conclusão de que a 
constituição de suas identidades não pode ser genuína ou homogênea, e que uma origem "pura" dessas "identidades em trânsito" dificilmente poderá ser recuperada.

No Relato, a narrativa em primeira pessoa foi adequada à construção de memória, de identidade e de alteridade. Ademais, a narração em voz feminina no início do livro ressalta o aspecto da alteridade da voz masculina do autor que deseja que sua história seja narrada por esta personagem. Essa voz insegura, que fala no início do Relato, é a relatora escolhida para contar sobre seu passado e que não se apresenta nominalmente para o leitor durante toda a narrativa.

Deitada na grama, com o corpo encolhido por causa do sereno, sentia na pele a roupa úmida e tinha as mãos repousadas nas páginas também úmidas do caderno aberto, onde rabiscara, meio sonolenta, algumas impressões do voo noturno. Lembro que adormecera observando o perfil da casa fechada e quase deserta... (p.9)

Ela vai procurando com "a chave da memória" (p.32) as identidades manauaras mestiças ao redor do percurso da mãe Emilie. Econtramos nessas "chaves" pretexto narrativo para a circulação do relato de uma voz para outra. Exemplos disso são: "o relógio" foi uma "chave" que evocou as lembranças de Hakim e "os cadernos" que passaram um entrenarrar para Dorner.

Também, ao estilo machadiano do "defunto autor", Hatoum faz uma metaficção ao pôr em cena uma relatora que nos conta sobre o processo de narração:

Gravei várias fitas, enchi de anotações uma dezena de cadernos, mas fui incapaz de ordenar coisa com coisa. Confesso que as tentativas foram inúmeras e todas exaustivas, mas ao final de cada passagem, de cada depoimento, tudo se embaralhava em desconexas constelações de episódios, rumores de todos os cantos, fatos medíocres, datas e dados em abundância. Quando conseguia organizar os episódios em desordem ou encadear vozes, então surgia uma lacuna onde habitavam o esquecimento e a hesitação: um espaço morto que minava a sequência de idéias. E isso me alijava do ofício necessário e talvez imperativo que é o de ordenar o relato, para não deixá-lo suspenso, à deriva, modulado pelo acaso. (...)Tantas confidências de várias pessoas em tão poucos dias ressoavam como um coral de vozes dispersas. Restava então recorrer à minha própria voz, que planaria como um pássaro gigantesco e frágil sobre as outras vozes. (pp.165 -166)

Por meio de uma carta ao irmão, a relatora vai rasgando o invisível de uma memória embaçada dos espaços familiares como a Parisiense e o sobrado. 
Enquanto Hatoum escrevia seu primeiro romance, se deparou com alguns problemas. O primeiro foi reconhecer que o passado recente não era bom para o romance, teve que ignorar as décadas de 1970 e 1960. Na primeira tentativa, começou a compor um romance em terceira pessoa, mas acabou percebendo que o mundo da subjetividade na ficção se adequava melhor à primeira pessoa do singular. Hatoum percebeu também que o narrador masculino também soava falso e então enfrentou a dificuldade de reproduzir o tom de uma mulher. Em um terceiro momento, o artista percebeu que não queria que o romance fosse dramatizado, com muitas cenas, pois, considerando Aristóteles, queria que soasse como uma forma direta e não indireta (drama). Isso além de querer que todas as personagens falassem na primeira pessoa. A solução para essas questões foi a narrativa epistolar que, ao invés de dar dramaticidade ou tons a todas as vozes, inscreve todas na mesma voz. (Aula com Milton Hatoum, 2009).

A narradora do Relato evoca o irmão em Barcelona referindo-se à Sagrada Família, talvez o monumento que melhor represente a modernidade em ruínas. A epígrafe de W.H.Auden Shall the memory restorel the steps and the shorel the face and the meeting place remete a possibilidade de um tempo restaurado pela mediação de muitas vozes. A rememoração extrai a experiência do passado para reorganizá-la, devolvê-la à vida da linguagem. Mas só pode fazê-lo enquanto ruína, enquanto linguagem em pedaços, numa língua migrante exilada. (CURY, 2007).

No Relato, temos uma narradora, que abre e fecha o romance, é quem reconstrói o mosaico de lembranças através das cartas que são a voz das outras personagens, pois ela sozinha não daria conta dessa reconstrução, uma vez que era muito pequena quando presenciou os fatos e que depois viaja e perde a continuidade da história. Por isso, Hatoum recorre à epístola de Dorner, o imigrante alemão, que viaja para Alemanha em 1955, enviada para Hakim, o filho de Emilie, que morava no sudeste do Brasil.

A técnica epistolar parece uma forma predileta para Hatoum, vemos como volta a reusar no conto "Uma carta de Bancroft", onde o narrador está na cidade estadunidense de Bancroft e vai até uma biblioteca da cidade onde encontra uma carta do escritor Euclides da Cunha, mandada ao amigo chamado Alberto Rangel, que estava no Rio de Janeiro: Em 1946, ela foi adquirida por um certo Charles P. Dutton num alfarrabista de Belém e doada três décadas depois para a Biblioteca de Bancroft, em Berkeley (SAMPAIO, 2010).

Prof a Aíla Sampaio (2010) nota que Hatoum consegue com essa técnica epistolar criar uma ilusão de verdade: 
Encontrar essa carta inédita em Bancroft, com a caligrafia nervosa de Euclides, é quase um milagre... só vim a Bancroft para ler uma carta amazônica do autor d'Os sertões" (p. 26). A suposta carta de Euclides da Cunha ao amigo Alberto Rangel, segundo o relato, conta, entre outras coisas, um sonho em que um militar é morto pelo amante da esposa, um dado biográfico de Euclides. Como para dar uma conotação de verdade, o conto termina com a seguinte observação: "Sabemos, enfim, que não há menção dessa carta na vasta correspondência de Euclides da Cunha. Por que não há menção dessa carta na vasta correspondência de Euclides da Cunha? O que o narrador quer dizer com essa observação? Aí está o jogo: não consta, por que está na Biblioteca de Bancroft ou não consta, simplesmente, por que a carta não existe, é uma criação do ficcionista.

\subsection{Vozes, silêncios e memórias compartilháveis}

No Relato, se mesclam as vozes de sombras das memórias da infância. Precisamos reinventar as vozes vencidas desarmoniosas e contraditórias, adeverte Maria Zilda Cury (2006):

O relato de memórias é compreensivelmente estratégia narrativa recorrente na literatura brasileira contemporânea, nos escritos que trazem o imigrante à frente da cena: os judeus de Moacyr Scliar ou de Samuel Rawett, os espanhóis de Nélida Piñon, os alemães de Fausto Wolff, os italianos de Zélia Gattai, os libaneses de Milton Hatoum (p.304).

O Relato de um certo oriente trouxe para a cena literária brasileira, junto com Lavoura Arcaica de Raduan Nassar, a voz de descendente de imigrantes árabes e suas memórias compartilháveis com outros sujeitos de outras imigrações. Para Hatoum, a memória é viva quando ela cria um espaço de dúvida. A escrita da memória é sempre mediada por uma "outra voz", construção textual ambiguamente própria e alheia, pessoal e comunitária: "Também deparei com outro problema: como transcrever a fala engrolada de uns e o sotaque de outros?”.

Figura 16: Representações de identidades diferentes na literaria brasileira (Maged El Gebaly, 2012)

\section{Colono $\rightarrow$ Estrangeiro: turista/viajante/imigrante $\rightarrow$ Descendente}

O Relato aborda ainda as interações entre os membros dessa família e das personagens de diversas identidades culturais de vários fluxos migratórios em Manaus: o curandeiro indígena Lobato, os sefarditas Shalom e Sara Benemou, os portugueses Américo e Comendador, a empregada Anastácia Socorro e o fotografo alemão Gustav Dorner. 
Milton Hatoum, na entrevista concedida à Professora Aida Hanania, conta que:

Eu misturei vozes da família e vozes de outras pessoas, de libaneses, de judeus, amigos que moravam na Espanha e na França, que me contavam histórias do Marrocos, da Síria... é muito curioso: há vozes que não são da minha família, mas de outras tribos, de outros clãs.

No Relato, a voz feminina jovem se dirige a um "tu" não nominado no texto e materializa a memória numa carta para seu irmão. Na narração, Milton faz do silêncio uma personagem que atravessa a família. Em muitos momentos, o silêncio aparece e provoca um processo de construção da memória a partir de ruínas familiares e dos amigos. Neste processo, o escritor evoca as ruínas de uma "canção sequestrada" do passado com uma linguagem subjetiva que soa a um estilo decadente pela instabilidade da narração que representa fronteiras flutuantes das identidades (ABDALA, 2002 e 2004; e VIEIRA, 2008).

\subsubsection{Vozes femininas}

Em artigos sobre Milton Hatoum, Maria Zilda Cury (2006, 2007 e 2009) ressalta a voz femenina como lócus da memória cultural da imigração:

A mulher guarda a iconoteca da memória família. A figura materna mistura-se a memória dos cheiros de comidas por ela preparadas, como uma marca a garantir e a estimular a memória. Degustação da comida associa-se a sedução amorosa feminina... A voz atribuída a Emilie brota da memória dos figos que comia em pequena na cidade natal e que fazem aflorar a narrativa á superficie dos lábios, desenrolando-se em relatos. $\mathrm{O}$ aroma dos figos era a ponta de um novelo de histórias narradas por minha mãe. (Hatoum, 1989, p. 90). Sociologicamente, a comida é lembrada como um fator a unir a vizinhança nos bairros de imigrantes, mantendo o paladar e afirmando a identidade, como o elo à memória das lembranças afetivas (CURY, 2007).

Joanna Da Silva (2011) apresenta uma análise comparativa das personagens femininas nas obras de Hatoum, desde a ótica do papel das filhas, das empregadas, das mães e das esposas.

Nas quatro obras, mães e filhas pertencem à classe alta da sociedade manauara, quer seja por intermédio de posses da família da qual são advindas - Emilie (Relato de um certo oriente, 1989), e Zana (Dois irmãos, 2000) são filhas de comerciantes libaneses bem sucedidos -, quer seja por meio do casamento com homens ricos e influentes na região, altos comerciantes, donos de embarcações, imóveis e propriedades em Manaus e seus arredores. O casamento, de certa 
forma, propicia a inserção dessas mulheres na alta sociedade manauara, como é o caso de Alícia, esposa de Trajano (Cinzas do Norte, 2005), e Angelina, esposa de Amando, filho de um influente comerciante português (Órfãos do Eldorado, 2008).

Respeito às figuras femininas no romance de Hatoum, Joanna da Silva (2011) diferencia entre os romances sobre a imigração e as outras que distanciam do tema imigratório:

Emilie e Zana constituem personagens centrais dessas duas narrativas: Relato de um certo Oriente (1989) e Dois irmãos (2000). Em uma primeira leitura, verificamos que se trata de mulheres belas, sensuais, esposas apaixonadas, mães extremamente protetoras, matriarcas que dirigem e decidem os rumos da família. Exercem, ainda, o papel de guardiãs da memória familiar de uma terra de origem, na medida em que cantam e contam histórias da terra deixada para trás, ou seja, um passado distante na terra natal.

Maria Luiza Germano de Souza (2010) defende a universalidade das personagens Emilie, Zana e Alícia:

Algo que reconhecemos nas mães dos três romances: Emilie, Zana e Alícia, modelos universais, míticas, pela proteção exacerbada dada aos filhos; nos casos de paternidades negadas (Nael, Raimundo); nos amores sem saída (Trajano, Ranulfo); na doação de vidas (as empregadas); na disputa entre irmãos (Omar, Yakub, Rânia). Trata-se de construção labiríntica, do eterno enredar e desenredar do cotidiano que encontra representações em qualquer sociedade (SOUZA, 2010).

Em relação das figuras das empregadas na obra de Hatoum, Joanna da Silva (2011) ressalta que:

As empregadas Anastácia Socorro e Domingas, egressas de conventos de Manaus, foram adotadas pelas matriarcas ainda muito jovens, e são de certa forma também imigrantes provenientes de alguma tribo indígena. Nenhuma das duas consegue romper com o passado distante e a cultura da qual descendem. Apesar de órfãs e destituídas, essas mulheres não se anulam culturalmente ao se integrarem às famílias dos patrões libaneses.

Também é interessante esta relação de amizade entre Emilie e Anastácia Socorro. Anastácia é ao mesmo tempo uma figura excluída socialmente e incluída no ambiente da casa libanesa. Negocia sua inserção nesse espaço pelo seu poder de narrar e a fascinação da sua 
cultura, que gera uma amizade entre ela e Emilie. Esta inserção se evidencia na mistura da culinária árabe com a amazônica, um laço que atava as duas mulheres.

Emilie ajudava Anastácia Socorro a trazer pães de massa folheada [...] e uma cesta com figos da Índia, genipapos, biribás, abacaxis e melancias; e numa cumbuca de barro cozido, entre papoulas colhidas no jardim, havia cachos de pitomba, réstias de maracujá do mato e outras frutas azedíssimas, que em contato com a língua provocavam calafrios no corpo e crispações no rosto... (p. 58).

Joanna da Silva (2011) analisa o problema das filhas no processo de declínio do patriarcalismo:

Samara Délia (no Relato) e Rânia (em Dois irmãos) são as filhas dessas famílias libanesas, sobre as quais recai um maior teor de discriminação, seja através dos resquícios de um regime tradicional em declínio (o patriarcalismo), como também da emergência do novo regime "pós-patriarcal", no qual a figura do pai e "protetor" é substituída pela do irmão ou filho. Interessado em construir seus próprios projetos individuais e em praticar sua liberdade, este não se mostra preocupado em proteger ou preservar a família, como caberia aos homens no regime tradicional. Desestabilizadas em sua segurança familiar, cabe, então, a essas mulheres atuar, não de forma espontânea ou nem tanto por aptidão, mas por obrigação, fora do ambiente doméstico, lugar antes reservado exclusivamente ao sexo masculino, pois, com a morte dos pais, alguém precisava administrar os negócios da família e manter o sustento da casa.

No Relato encontramos aqui um exemplo de uma relação de alteridade agressiva é o preconceito que sofre a Samara Délia por ser mãe solteira, que vem dos irmãos que se preocupam com a imagem da família diante dos moradores da cidade. Quanto ao seu pai, apesar de apresentar uma forte religiosidade, acolhe a filha. Milton apresenta um regime patrical do pai em decadência. Este regime se transforma no regime patriarcal do irmão.

O velho protegia a filha com unhas e dentes e, no fim da vida parecia mais preocupado com ela que a esposa. Diz que levava flores e plantava mudas de fruteiras no quintalzinho dos fundos, e um dia, antes do amanhecer, foi ao mercado para comprar peixes, legumes e frutas e convidou Emilie a almoçar na Parisiense. Emilie quase não acreditou. Disse: "Se não for uma fraqueza da idade, posso jurar que não há mais homens inflexíveis na face da terra". Mas havia pelo menos dois, porque os filhos sopravam palavras de insulto ao mencionar o nome da irmã. E por que fizeram isso? Porque na rua, nos clubes, nos bares, por toda parte eram perseguidos por olhares ora reticentes ora indagadores... (p. 128). 
A imigração como tema na literatura brasileira contemporânea propicia um novo olhar sobre a questão da identidade nacional, na medida em que revela processos de integração transculturais. Milton Hatoum, descendente de libaneses, dialogando, portanto, com sua herança cultural, e Ana Miranda, escritora cearense que tem se dedicado à ficção histórica, teceram representações do imigrante libanês sob óticas diferenciadas. O desvelar da tessitura ficcional em diferentes manifestações da memória (a real, de Hatoum, e a de empréstimo, de Ana Miranda) e concretizadas em protagonistas femininas, justifica, por si só, a motivação e a relevância deste projeto (CARREIRA, 2009a).

A trajetória das personagens femininas marca muitas outras narrativas da imigração libanesa como Amrik (1997), da Ana Miranda, autora nunca esteve no Líbano, embora tenha sido casada com um descendente de libaneses, o sociólogo Emir Sader. "Este livro surgiu como uma homenagem ao meu marido, Emir Sader, que é filho de libaneses". Como disse Miranda: "foi uma tentativa de conhecê-lo melhor, através de suas raízes”. A história de Amina é contada numa linguagem que floresce das partes profundas da mente. Temos dois pontos importantes neste romance de Ana Miranda, a primeira é a migração libanesa, a segunda, a trajetória da narradora e protagonista a garotinha Amina. A história conta a vida de Amina e seus familiares. Amina é uma garotinha que vive no Líbano e desde pequena aprende a cultura do seu povo, principalmente com a sua avó Farida, uma libanesa que cultiva todas as tradições do seu povo na pequena aldeia onde vivem, nas montanhas Mdúkha. Avó Farida, referência feminina para Amina, é ela quem vai ensinar Amina a arte da dança e conta histórias sobre Maimuna deixando sempre claro a semelhança entre mãe e filha que o destino havia separado. Como o Relato de um certo oriente, a narrativa de Amrik é cíclica; começa e termina no Jardim da Luz, quando o tio da narradora, Amina, transmite-lhe o pedido de casamento do mascate Abrahão. As lembranças de Amina surgem fragmentadas e são transcritas em 154 textos breves, à guisa de capítulos, agrupados em 11 partes (CARREIRA, 2008).

\subsection{Narrativa circular, heterobiográfica e fractária}

Dentre alguns dos elementos da tradição literária árabe no romance, a estrutura narrativa polifônica é um dos traços importantes a serem destacados. O livro é composto por capítulos nos quais se alternam as vozes narrativas como as imagens de um caleidoscópio. Há uma relatora 
principal que testemunha em primeira pessoa no primeiro e no último capítulo, as histórias retrospectivas em primeiras pessoas por outras personagens que compõem o Relato ao longo dos capítulos. Narradores em trânsito também contam o livro em primeira pessoa. Deste modo, o livro é composto por múltiplas perspectivas e diversas identidades narrativas, "eus", que descrevem seus orientes. Cada personagem-narrador, por sua vez, é também um "eu” dividido pela experiência híbrida da identidade mista - a convivência dentro de uma casa simultaneamente árabe e brasileira, muçulmana e cristã (IEGELSKI, 2006). O aspecto fragmentado da narrativa, a história da família narrada por múltiplas vozes e perspectivas através de uma carta, faz com que o romance dialogue com a tradição da narrativa árabe antiga, como As mil e uma noites. $\mathrm{Na}$ passagem a seguir, o pai faz uma descrição inspirada nas d'As Mil e uma noites da imagem do alvorecer na floresta.

Às cinco e meia tudo ainda era silencioso naquele mundo invisível; em poucos minutos a claridade surgiu como uma súbita revelação, mesclada aos diversos matizes do vermelho, tal um tapete estendido no horizonte, de onde brotavam miradas de asas faiscantes: lâminas de pérola e rubis; durante esse breve intervalo de tênue luminosidade, vi uma árvore imensa expandir suas raízes e copa na direção das nuvens e das águas, e me senti reconfortado ao imaginar ser aquela a árvore do sétimo céu. Ao meu redor todos ainda dormiam, de modo que presenciei sozinho aquele amanhecer, que nunca mais se repetiria com a mesma intensidade. Compreendi, com o passar do tempo, que a visão de uma paisagem singular pode alterar o destino de um homem e torná-lo menos estranho à terra em que ele pisa pela primeira vez. (pp. 72-73).

Ainda, observamos que esta descrição, a diferença das descrições d'As Mil e uma noites, mistura a natureza com os sentimentos do protagonista, mas, ao mesmo tempo, trata-se de uma ficção brasileira moderna que reflete uma mistura de culturas com seus encontros e desencontros. A narradora principal do Relato começa e fecha a narrativa da qual emanam outras narrativas e outros narradores. As Mil e uma noites tem uma narrativa polifônica espiral, enquanto o Relato é um mosaico polifônico de narrativas e de vozes. (KRUGER, 2002, apud CRISTO, 2005). É um tipo de narrativa caracterizada pelo que Antonio Candido (1985) chama heterobiografia:

A experiência pessoal se confunde com a observação do mundo e a autobiografia se torna heterobiografia, história simultânea dos outros e da sociedade; sem sacrificar o cunho individual, filtro de tudo, o narrador poético dá existência ao mundo de Minas no começo do século. (p.55). 
O escritor constrói uma narrativa heterobiográfica a partir de dez histórias. São oito entradas de texto com numeração marcando o início de cada relato e há mais duas que não estão numeradas. Ao estilo da heterônimia de Fernando Pessoa, Milton Hatoum "democratiza" a narração com o movimento narrativo da voz feminina da relatora num mosaico polifónico circular de cinco narradores (GOMES, 2005 e TOLEDO, 2006):

Figura 17: Estrutura completa dos capítulos do Relato (REZENDE, 2010, p.73)

Função Narrador-Função Ouvinte

Cap. 1 Relatora retorna a ManauasIrmão

Cap. 2 Hakim fala da sua vida-Relatora

Cap. 3 Gustav Dorner fala da sua vidaHakim

Cap. 4 O pai da relatora, esposo de Emilie-Dorner

Cap. 5 A Gustav Dorner Hakim

Cap. 5 B Hakim Relatora

Cap. 6 RelatoraIrmão

Cap. 7 Hindi Conceição -Relatora

Cap. 8 Relatora-Irmão

Esta organização polifônica circular é o meio do escritor para construir a subjetividade manaura da narradora, cuja identidade sem nome se vislumbra vagamente nos entrelugares das narrativas de vários narradores. A construção das vozes narrativas se dá no Relato também através da dualidade: cada personagem se dirige a um segundo personagem, o que torna a narração mais complexa, pois é preciso buscar o narrador e o seu interlocutor.

Sabia que tinha sido eleito o interlocutor número um entre os filhos de Emilie: por ter vindo ao mundo antes que os outros? Por encontrar-me ainda muito próximo às suas lembranças, ao seu mundo ancestral onde tudo ou quase tudo 
girava ao redor de Trípoli, das montanhas, dos cedros, das figueiras e parreiras, dos carneiros, Junieh e Ebrin?

\subsubsection{Multiperspectivismo cultural}

Hatoum aponta na sua tessitura narrativa um certo perspectivismo cultural, ou seja, transfigura a mesma cena de diferentes perspectivas. As lembranças, da mesma cena de um rito cultural, são apresentadas através de diferentes posicionamentos. Esse perspectivismo pode ser derivado de uma ontologia perspectivista ameríndia que considera a passagem de sujeito a objeto é uma mudança de posição. Nesse mundo perspectivista, é o corpo que funciona como o principal diferenciador (VIVEIROS DE CASTRO, apud HATOUM, 2005c). Por exemplo, na seguinte passagem, se evocam diferentes olhares sobre o ato de comer o fígado cru do carneiro. (KANZEPOLSKY, 2008).

Mas o rosto de Anastácia Socorro se crispava por outra razão: depois de arrumar a mesa, ela se refugiava numa das alfurjas da casa, para não presenciar a cena da comilança. No centro de um pátio iluminado pelo sol equatorial, homens e mulheres repetiam o hábito gastronômico milenar de comer com as mãos o fígado cru de carneiro. Não era a um ritual bárbaro ou ao sacrifício de um animal que eu assistia do quarto dos pais, mas sim a uma novidade assombrosa, a uma festa exótica que tanto contrastava com o ritmo habitual da casa. Havia extravagância e prazer nos gestos para saciar a bulimia. P.58.

Na cena da morte do pai, Hatoum ressalta este perspectivismo cultural na interpretação do deslocamento do ritual muçulmano para o cristão no enterro em Manaus:

Fiz o sinal da cruz, como muito que passam ao lado deste túmulo e ficam abismados porque não há cruz, nem coroa de flores, nem imagem de santo, nenhum sinal de morto cristão... Eu mesma relutei em acreditar que um corpo em Manaus estivesse voltado para Meca, como se o espaço da crença fosse quase tão vasto quanto o Universo: Um corpo se inclina diante de um tempolo, de um oráculo, de uma estátua ou de uma figura, e então todas as geografias desaparecem ou conluem para a pedra negra que repousa no íntimo de cada um.

Com esta narração o escritor dialoga com "o estado lacaniano do espelho", no que tende a ver o outro como um reflexo do "eu" no espelho, uma situação que apaga as diferenças do "o não Eu". Na complexa narrativa hatoumiana de identidades aportam em diferentes caras de alteridades. Hatoum não se limita à construção de imagens e memórias do sujeito híbrido, mas vai, além disso, para a construção de suas relações transculturais com outras identidades. 
Abaixo, observamos este multiperspectivismo na vista parcial de pintura do teto no Salão Nobre do Teatro Amazonas, feita pelo artista italiano Domenico de Angelis, a pintura representa a glorificação das belas artes no Amazonas (a dança, a pintura, a música e o teatro). Nessa imagem observamos a técnica do multiperspectivismo na representação das figuras nas pinturas do teto do Teatro Amazonas. 
Figura 18: Pintura do teto no Salão Nobre do Teatro Amazonas (Maged El Gebaly, Manaus, 16/05/2012).

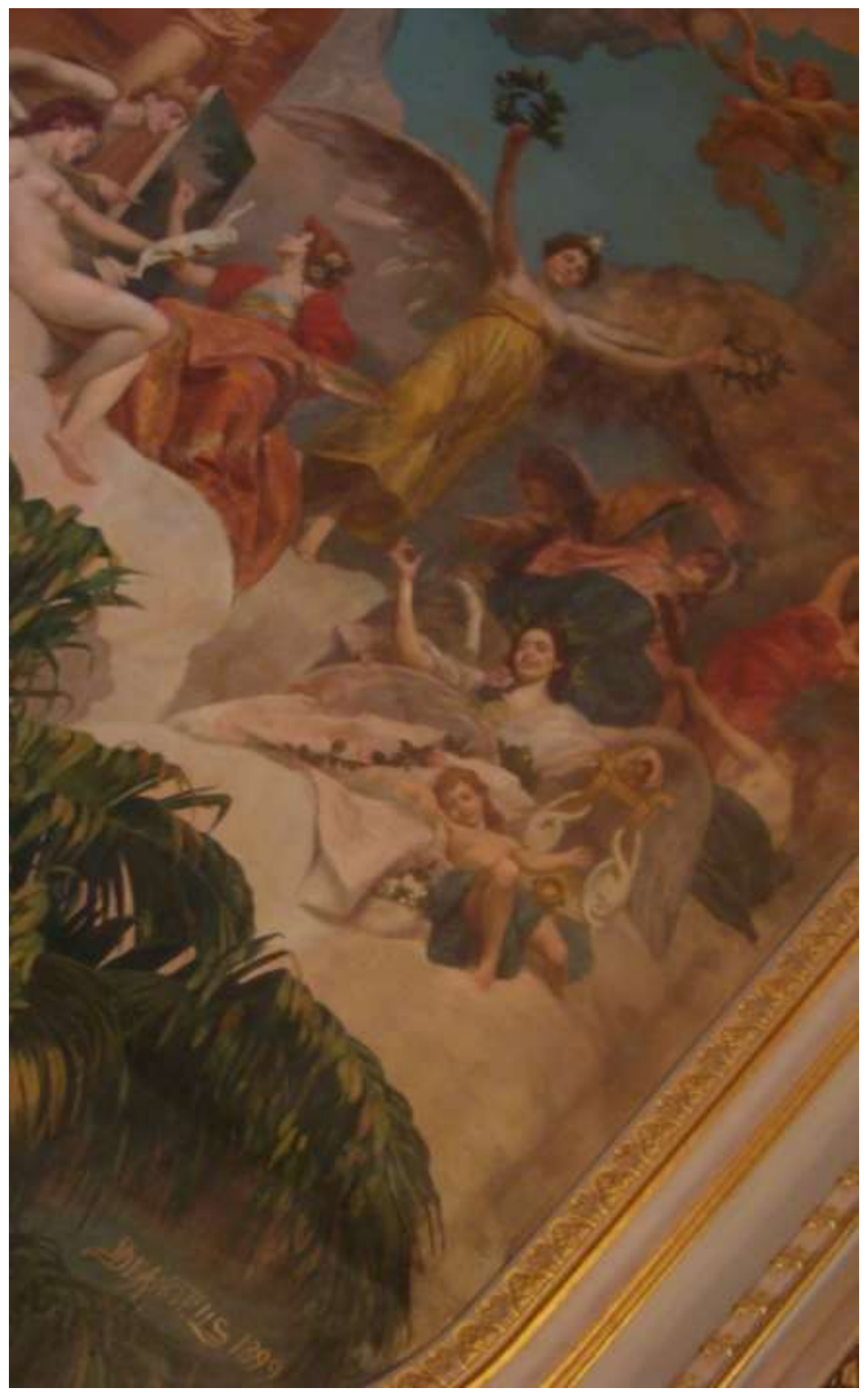




\title{
3.7. Olhar transitório, exotismo e autoexotismo
}

\author{
"Os turcos nasceram para vender \\ bugigangas coloridas em canastras \\ ambulantes.
}

Têm bigodes pontudos, caras

de couro curtido,

braços tatuados de estrelas.

Se abrem a canastra, quem resiste

ao impulso de compra?

É barato! Barato! Compra logo!

Paga depois! Mas compra!

A cachaça, a geléia, o trescalante

fumo de rolo: para cada um

o seu prazer. Os turcos jogam cartas

com alarido. A língua cifrada

cria um mundo-problema, em nosso mundo

como um punhal cravado.

Entendê-los, quem pode? [...]

Os turcos,

meu professor corrige: Os turcos

não são turcos. São sírios oprimidos

pelos turcos cruéis. Mas Jorge Turco

aí está respondendo pelo nome, e turcos todos são, nesse retrato

tirado para sempre... Ou são mineiros 
de tanto conviver, vender, trocar e ser

em Minas: a balança

no balcão, e na canastra aberta

o espelho, o perfume, o bracelete, a seda,

a visão de Paris por uns poucos mil-réis?"

(Carlos Drummond de Andrade, Os Turcos, Boitempo II, 1973)

O exotismo é um olhar que coloca o outro num esquema pré-estabelecido como um objeto inferior instrumentalizado. Consoante a José Leonardo Tonus (2005), o exótico no Relato é relativizado:

O Relato "pode propor para um público europeu o cruzamento de dois universos fantasiados, imaginados, construídos e desejados a partir dos fantasmas exóticos: os universos amazônico e oriental" (...) No Relato observamos a utilização de uma série de estratégias narratológicas e poéticas com o objetivo de neutralizar o aparecimento de uma deriva exótica. Entre as principais estratégias, podemos citar, por um lado, o emprego de sujeitos de enunciação próximos da situação narrativa e, por outro lado, o processo de dessacralização do elemento exótico. (...) Para Hakim, o autoexotismo é uma etapa transitória do seu processo de formação pluricultural cujo objetivo é levá-lo ao conhecimento dos outros e de si próprio. Nos contatos interculturais, o estereótipo cultural de que se compõe o elemento exótico hatoumiano pode também contribuir com o processo de comunicação, estabelecendo, como nos sugere o autor, zonas temporárias de tradução cultural que, apesar de sua equivocidade e limitação, conduzem o "Mesmo" a um diálogo com o "Outro" (TÔNUS, 2005).

\subsubsection{Dorner}

Dorner parece ser o único personagem consciente da sua condição de estrangeiro. Anda com sua câmera batendo fotos que servem de registros das memórias familiares da cidade. Ele é uma figura amistosa. Estabelece amizade com todo o mundo, embora seu olhar seja o do turista europeu. Segundo o relato de Dorner, o pai de Hakim teria partido para o Brasil não para "fazer a América", mas para "enfrentar o oceano e alcançar o desconhecido, no outro lado da terra" (p. 72). No capítulo 5, Dorner comenta sobre o papel das Mil e uma noites como ponte da sua 
amizade com o pai de Hakim. A visão orientalista do imigrante alemão Dorner acha que o pai mistura passagens da sua vida com As Mil e uma noites (FREIRE, 2006; MOREIRA, 2007):

O convívio com teu pai me instigou a ler As mil e uma noites, na tradução de Henning. A leitura cuidadosa e morosa desse livro tornou nossa amizade mais íntima; por muito tempo acreditei no que ele me contava, mas aos poucos constatei que havia uma alusão àquele livro, e que os episódios de sua vida eram transcrições adulteradas de algumas noites, como se a voz da narradora ecoasse na fala do meu amigo. No início da nossa amizade ele se mostrara circunspecto e reservado, mas ao concluir a leitura da milésima noite ele se tornara um exímio falador. Ás vezes, a leitura de um livro desvela uma pessoa. Mas o curioso é que ele sempre deixava uma ponta de incerteza ou descrédito no que contava, sem nunca perder a entonação e o fervor dos que contam com convicção. Os fatos e incidentes ocorridos na família de Emilie e na vida da cidade também participavam das versões confidenciais por teu pai aos visitantes solitários da Parisiense. O que me fez pensar foi a coincidência entre certas passagens da vida de outras pessoas, que mescladas a textos orientais ele incorporava à sua própria vida. Era como se inventasse uma verdade duvidosa que pertencia a ele e a outros. Fiquei surpreso com essas coincidências, mas, afinal o tempo acaba borrando as diferenças entre uma vida e um livro. P.79.

José Leonardo Tonus (2005) notou a visão exotizante de Dorner:

A percepção endótica da natureza amazônica proposta por Hakim na cena em que ele comenta a paixão de Dorner por orquídeas, ícone incontestável do exótico tropical, é um exemplo concreto de tal procedimento. Para o olhar europeu, as orquídeas encerram por si próprias uma possibilidade de evasão fantasmática, ao passo que para as personagens acostumadas à realidade exótica, como Hakim, tal percepção é inoperante. As orquídeas evocadas por Dorner com tanto entusiasmo e veemência eram para Hakim apenas "simples palavras" que encerravam algum "mistério" (p. 60) (...)A máquina fotográfica não somente dirige, conduz, reduz a percepção de Dorner, como também instaura entre a personagem e o objeto visado e visualizado uma relação de distanciamento. (...). As lentes de sua câmera, de seus óculos e as pupilas azuladas dos seus olhos formam no texto um único sistema ótico a tal ponto que ao olhar para a Hassel, Dorner "via seu próprio rosto" (p. 60). (TÔNUS, 2005).

O tema do olhar estrangeiro tem sido revisitado no conto "Manaus, Bombaim, Palo Alto", que aborda a vida do Almirante indiano Rajiv Kumar Sharma em Manaus. O jornalista indiano visita a casa do escritor (narrador-personagem) a fim de conhecê-lo, e escreve em seu jornal que a casa do rapaz era uma imundície. 


\subsection{Entrelugar e memória dialógica}

Figura 19: Do "não lugar" ao "entre-lugar" (Maged El Gebaly, 2012).

\section{Não lugar $\rightarrow$ Entrelugar}

O entrelugar, termo cunhado por Silviano Santiago em 1978, indica uma incerteza entre duas posições discursivas, ou entre a posição dominante e sua negação pura. A categoria entrelugar emerge de um quadro político dos anos 60 em que "falar, escrever, significa: falar contra, escrever contra" (SANTIAGO, 1978, p.19) como resposta a um silêncio desejado pelo imperialismo cultural que reduzia o povo apenas a leitores, comentadores e consumidores passivos. Como bem explica Denilson Lopez ${ }^{11}$ (2010): o entrelugar é uma provocação a pensar alternativas aos grandes sistemas totalizantes, homogeneizados e excludentes. O entre-lugar é espaço concreto e material, político e existencial, local, midiático e transnacional, de afetos e memórias. Santiago avança com relação à formulação tradicional da fusão de culturas ao: "Na álgebra do conquistador, a unidade é a única medida que conta," comenta ele, pp. 14-15.

Nesse senitdo, Myriam Correa de Araujo Avila ${ }^{12}$ (2009) detecta no discurso de Silviano Santiago como tarefa primordial da nova crítica na América Latina: a destruição sistemática dos dois conceitos: unidade e pureza, como dois pilares do discurso de dominação. O entrelugar não significa, portanto, a soma mestiça de 0 e 1, mas uma posição clandestina e indeterminada que oscila "entre o sacrifício e o jogo, entre a prisão e a transgressão, entre a submissão ao código e a agressão, entre a obediência e a rebelião, entre a assimilação e a expressão (...).” p.26. Santiago dá margem a ocupar diferentes posições simultaneamente, sem que uma delas se apresente como a verdadeira e sem que haja impostura, e sim fragmentação, nesse desdobramento.

Deixando de lado o princípio de identidade, torna-se possível, à revelia da experiência empírica que costuma guiar nossas operações mentais, propor que o mesmo objeto (teórico)

\footnotetext{
${ }^{11}$ LOPES, Denilson. "Del Entre-Lugar a lo Transcultural". In: Marina Moguillansky; Andrea Molfetta; Miguel Angel Santagada. (Org.). Del Entre-Lugar a lo Transcultural. 1ed.Buenos Aires: Teseo, 2010, p. 19-42.

${ }^{12}$ AVILA, Myriam Correa de Araujo. "A posição do discurso latinoamericano”. In o Eixo e a rdoa. Belo Horizonte. v.18, n.2, 2009.
} 
ocupe dois lugares ao mesmo tempo. Maria Anontienta Pereira ${ }^{13}$ observa que o pensamento crítico de Silviano Santiago também se orienta por meio de referências móveis. Para Silviano, desde a paródia da modernidade até o pastiche da pós-modernidade, os autores têm desenvolvido propositadamente um texto de segunda mão, fato que os leva ao paradoxo de exercitar a criação enquanto citação.

No Relato, Paulo César Silva de Oliveira (2008) define a identidade na obra de Hatoum como zona de fronteira nos entrelugares:

A questão da identidade forma uma espécie de zona de fronteira, que nos leva, em Milton Hatoum, a pensar a ideia de nação e nacionalidade como algo imaginado nas frestas, em entrelugares. O poder, ou os poderes da ficção, nesse caso específico, quase único na prosa brasileira atual, estão a nos reapresentar o mundo, não mais pelos caminhos apontados a partir de 1922, mas no embate com as formas complexas de organização identitária, sejam elas locais ou universais, nacionais ou planetárias, individuais ou da massa.

A narrativa transcultural do Relato manifesta uma relação não cronológica entre o descendente manaura de árabes e a terra da origem da imigração, uma relação que se constrói com uma memória involuntária, não linear, associativa. O descendente interage no romance com o ato de recordar por meio de monólogos dialogantes consigo na sua vivência misturada entre o mundo da casa (família e comunidade) e o mundo da rua (a sociedade). Focando no Relato, encontramos uma narrativa que revela diferentes identidades e interações interculturais. Essas interações se manifestam na recolha das ruínas da memória pessoal do escritor para construir a identidade da família líbanomanaura. (FRANCISCO, 2007).

Essas memórias íntimas refletem uma geração em crise. Por exemplo, em muitas partes de Cinzas do Norte (2005), Hatoum resgata as memórias culturais de Manaus dos anos 1950-1960 e daquela geração brasileira que viveu sob a ditadura militar durante os Anos do Chumbo (19681974), um momento histórico em que não havia espaço de expressão da alteridade. O romance desenvolve-se entre dois meninos: Raimundo (Mundo), filho de Alícia e Jano; e o narrador principal Olavo (Lavo), órfão de pai e mãe, criado pela costureira Ramira e seu irmão Ranulfo. A

\footnotetext{
13 PEREIRA, Maria Antonieta. "Entre-lugar e ex-tradição - as picadas do discurso latino-americano". In: XVII Encontro Nacional da ANPOLL, 2002, Gramado - RS, 2002.
} 
narração consiste no relato de Lavo, entremeada pela carta de tio Ranulfo a Mundo. Nas cartas, Ranulfo narra a história de amor vivida por ele e pela mãe de Mundo, Alícia. Desde criança, aflora-se em Mundo o interesse pela pintura e pela arte, porém, seu pai, homem ligado ao extrativismo e amigo de militares, o quer como futuro sucessor junto à sua produção de juta em Vila Amazônia - ilha próxima a Manaus, onde o pai de Mundo pretende plantar a civilização. Mundo, no entanto, frequenta o ateliê do pintor Arana, deixando o pai enfurecido. Em meio a muitas brigas, Mundo acaba por entrar em uma escola militar. Todavia, acaba expulso e depois de uma terrível discussão com o pai, este falece (CARREIRA, 2009b).

Na sua contextualização de Cinzas do Norte, Joanna da Silva (2011) aborda o conflite entre Mundo e seu pai, aliado do governo militar: Respeito a essa questão do conflito pai-filho, Hatoum (2010) nos contou:

Cinzas do Norte faz parte também da minha vida, da minha geração, que vivenciou essa época, que cresceu durante o regime militar, sobretudo no Cinzas do Norte, onde há as relações do pai de Mundo com os militares, relações muito fiéis e comprometedoras. Então, alem do conflito com o pai, o personagem Mundo esbarra na relação do pai com os militares. É uma dupla tirania, a do pai e a do país. Mundo se depara com um ambiente adverso em Manaus, onde o pai, a província e o regime militar o oprimem. Ele é um "estranho" em sua própria terra. Mas anos depois, quando mora em Berlim e Londres, ele se torna um autoexilado, um expatriado com pouca interlocução, e cerceado pela imagem sufocante do pai (Milton Hatoum, 2010).

Raduan Nassar publica sua obra prima Lavoura arcaica em 1975. Jorge Amado, escritor consagrado no campo literário brasileiro escreve A descoberta da América pelos turcos em 1992. Milton Hatoum publica o Relato de um certo oriente em 1989. Joanna da Silva observa que:

Já Sarah Wells, no trabalho intitulado "O improvável sucessor de Nassar: a genealogia alternativa de Milton Hatoum" (2007), busca, por meio de uma análise comparativista entre a escrita de Milton Hatoum e Raduan Nassar, possíveis afinidades que possam ligar os dois autores líbano-brasileiros. Ela observa que, em determinados momentos, ambos constituem posições com marcas e referências distintas. Enquanto Nassar se aproxima da prosa poética modernista, Hatoum investe na arte de contar história por meio de uma linguagem exuberante, embora ambos nos convidem a refletir acerca do difícil projeto de articular identidades fora de um conceito multiculturalista estreito e limitado (SILVA, 2011). 
Érica Gonçalves (2008) observa um arquétipo de famílias patriarcais em Lavoura Arcaica:

Lavoura Arcaica é em seu contexto um arquétipo das histórias de famílias patriarcais que nascem junto com as primeiras histórias religiosas e perduram até os dias atuais. A figura da "Família" como uma sociedade inviolável; a imagem do "Pai" como alguém de extrema sabedoria; da "Mãe" como uma figura secundária, e do primogênito, no caso Pedro, como alguém que deverá perpetuar a sabedoria patriarcal são alguns pontos que afirmam esta tese.

Miguel Vieira (2007) apela à fase de adaptações nas referências dos personagens em Lavoura Arcaica:

André é um adolescente de dezessete anos que mora numa pequena propriedade rural, presume-se que seja no interior do Brasil, junto à sua família: o pai (Iohánna), a mãe (sem nome explicitado), o irmão mais velho (Pedro), Zuleika, Huda e Rosa (irmãs intermediárias), Ana (irmã imediatamente mais nova que ele) e Lula (filho caçula). É uma família de imigrantes libaneses adaptando-se às condições religiosas, sociais e culturais do novo país. Vemos isso pelo sincretismo religioso católico/muçulmano, pelas referências à língua árabe e pelos rituais coletivos de comemoração que permeiam a narrativa.

Granja (2007) apresenta a condição de estrangeiro nas narrativas dos descendentes de árabes como Raduan Nassar e Milton Hatoum:

Adverte-se aí um impasse existencial, um doloroso apartamento das origens e uma busca hesitante de inscrição no destino. Por um lado, temos uma origem enraizada nos milênios, na qual se entrecruzam as tradições maronitas e mulçumanas. Por outro, um destino que se constitui historicamente como porto de chegada, solo onde se operam novos cruzamentos e novos enraizamentos de desenraizados (transplantes). É nesse sentido que Raduan Nassar (como Milton Hatoum) é um autor que problematiza a família de imigrantes libaneses no Brasil. Toda família evoca a questão da herança. Mas nesta se afigura a complicada reprodução ampliada de uma linhagem que sofreu o trauma de um deslocamento. A imbricação desses processos desencadeia a tragédia em Lavoura arcaica. 
Elias Silva (2005) ressalta a questão do conflito geracional nas famílias dos imigrantes em Lavoura Arcaica: (o romnce) representa o conflito entre a tradição representada por Iohana, o Pai, e André, o filho, polos de um embate cujo resultado, se é previsivel, nem por isso é menos doloroso, dado que suprime, de modo brutal em seu epílogo, um universo mediante a eclosão de outro.

Na novela Órfãos do Eldorado (2008), Milton explora um novo rumo estético - em que se vale de um mito popular com reverberações oníricas - ao compor uma trama sentimental, de uma época de fausto e decadência na Amazônia brasileira. Lucimara Vasconcelos (2010) analisa o conflito entre Arminto (o filho) e Armando (o pai):

Órfãos do Eldorado descreve as lembranças de Arminto Cordovil, filho de Amando Cordovil, um rico empresário no setor de transporte fluvial na região amazônica. Arminto vive desde a infância uma situação de hostilidade por parte do seu pai, que o vê como culpado pela morte da mãe por ocasião do parto. Por volta dos vinte anos, o jovem é expulso de casa depois de ser flagrado numa tarde de amor com Florita, empregada da casa e - insinua o protagonista possível amante de Amando. Arminto é, assim, obrigado a deixar a confortável casa do pai, em Vila Bela, chamada de Palácio Branco e morar num quarto da pensão Saturno em Manaus. (...) Em Manaus, Arminto vive de trabalhos simples e esporádicos, recebendo eventualmente visitas de Florita e de Estiliano, advogado e melhor amigo de Amando. A conselho de Estiliano, Arminto volta a estudar, na esperança de obter o perdão e a aceitação do pai, mas a morte súbita deste impossibilita a reconciliação. No funeral do pai, Arminto se encanta com uma jovem órfã chamada Dinaura, que se encontra sob o cuidado de freiras carmelitas, e, com a intermediação de Estiliano, obtém da madre superiora permissão para o namoro. Vivendo em Vila Bela, Arminto se encontra regularmente com a órfã Dinaura, com quem tem a intenção de se casar, e chegam a ter um único encontro sexual, mas Arminto é chamado às pressas a Manaus para tratar dos negócios do pai. O naufrágio do Eldorado, um cargueiro de grande porte, sem seguro e adquirido à custa de um vultoso empréstimo junto a um banco inglês, acaba levando a empresa à bancarrota. (...) De volta à Vila Bela, Arminto é surpreendido pelo desaparecimento de Dinaura que, segundo dizem, fugiu para uma Cidade Encantada. Por fim, Arminto vende as últimas propriedades da família, para que sobre a ele e Florita um mínimo de conforto material, mas também isso é dissipado numa vida de prodigalidade. 
O conto "Dois poetas da província" é a história de Albano, um jovem que queria ser poeta em Paris, e de Zéfiro, um homem bem mais velho, experiente, que sabia de tudo sobre Paris e os poetas franceses, mesmo sem nunca ter ido à França - mas esse detalhe ninguém sabia. Sua vida era um enigma, assim como a casa em que ele morava. No conto Hatoum narra a última conversa entre dois intelectuais manauaras - Albano e Zéfiro - aquele ainda jovem e prestes a embarcar para Paris onde pretendia começar a vida de poeta, e este, octogenário, que jamais iria terminá-la, pois se julgava um poeta imortal. Sua paixão por Paris era pública e, não poucas vezes patética. $\mathrm{O}$ imortal cita nomes e lugares com uma familiaridade acima de qualquer suspeita, lembrando que ali mesmo naquele restaurante onde degustavam um peixe pescado no Negro, recepcionara há muitos anos os diletos amigos Sartre e Simone de Beauvoir. A conversa se estendeu, embora Albano estivesse com pressa. Finalmente se despedem. O ancião vai para casa, onde livros de poesia e manuscritos se atulham pelo chão, em meio a pilhas de velhos jornais e revistas francesas. Zéfiro começa a recitar poemas de Lamartine, Victor Hugo e Baudelaire. Repete nomes de logradouros parisienses e, fatigado, pousa os olhos no mapa da cidade que sempre sonhou conhecer, mas era tarde. "Bocejou, a cabeça oscilou e estalou no encosto". O protagonista, Zéfiro, um velho poeta e professor de francês, vive exilado em seu próprio mundo desmoronado. Esse conto evoca a temática do duplo em Jorge Luis Borges (SAMPAIO, 2010).

O conto "A casa ilhada" narra a saga de vingança do cientista Lavedan, pesquisador renomado de espécies de peixes, transtornado por um caso de traição da sua mulher Harriet, que o abandona para ficar com um dançarino manauara. Já o Levedan, retorna a Zurique sem Harriet, onde fica morando em Manaus, num bangalô sobre as águas, a casa ilhada, onde Levedan, anos depois volta, para uma visita misteriosa. O conto apresenta as atitudes de um casal de identidade mais globalizada e suas interações com a cultura manaura local (SAMPAIO, 2010).

$\mathrm{Na}$ narrativa, são perceptíveis algumas imagens interculturais que permeiam as duas culturas e os processos pelos quais os personagens imigrantes e seus filhos passam a lidar com esses contatos interculturais. No Relato mesclam-se as memórias da infância, mediação de múltiplos espaços culturais: o religioso, o político, o literário (Cury, 2003). A hibridação transcultural atua em múltiplas instâncias na vida da família de Emilie. Por exemplo, a própria culinária é uma mescla intercultural de temperos e ingredientes manauaras e árabes. O olfato também toma o lugar do sentido que desperta as demais sensações e disso se pode concluir que é 
o mais forte para a personagem. É o cheiro que transporta a protagonista para o passado e abre a porta das lembranças da infância. É especialmente por ser o universo da memória que os sentidos são importantes, pois são eles que armazenam as emoções e é através de um cheiro, uma cor, um som que se consegue reconstruir uma lembrança: "A atmosfera da casa estava impregnada de um aroma forte que logo me fez reconhecer a cor, a consistência, a forma e o sabor das frutas que arrancávamos das árvores que circundavam o pátio da outra casa.”. P. 10.

O Relato mostra também uma tradição árabe antiga de se apaixonar primeiro pela audição antes do que pela visão: "Afinal, tinham vivido muitas décadas. Emilie era a única filha e, de tanto ouvir falar dela, enamorei-me.”. P.76.

Há também o ato de aprendizado da língua árabe que o personagem Hakim narra (FREITAS, 2001). Ele, como filho mais velho de Emilie, teve um contato maior com a língua, conforme ele mesmo narra:

Já estava me habituando àquela fala estranha, mas por algum tempo pensei tratar-se só de uma linguagem falada pelos mais idosos; ou seja, pensava que os adultos não falavam como as crianças. Aos poucos me dei conta de que eles gesticulavam mais ao falar naquele idioma, e houve casos em que intuí idéias através dos gestos. Numa noite em que bisbilhotava a conversa, perguntei se conversavam sobre o vizinho. Responderam que falavam de mim, da minha curiosidade, do fato de eu querer vagar entre vozes que escutava sem compreender. Nessa noite, ao me acompanhar até o quarto, minha mãe sussurrou que no próximo sábado começaríamos a estudar o 'alifebata'. Sentada na cama, me confidenciou que sua avó lhe ensinara a ler e escrever, antes mesmo de frequentar a escola...(pp.50-51).

Respeito á escrita das cenas nas quais Hakim está tentando aprender a língua árabe, Susana Moreira (2012) conta:

Fez coisas que não tornaria possivelmente a fazer, como estudar Árabe com uma professora argelina, sua colega na Universidade de Manaus, para escrever as duas páginas em que Hakim conta como aprendeu, na infância, a língua que a família tinha trazido, como um daqueles objetos misteriosos. 


\section{Capítulo IV: Pré-tradução árabe de Relato de um certo oriente}

A compreensão e a interpretação na tradução foram pesquisas que tiveram diferentes óticas. O positivismo tradicional reduziu os estudos da tradução à mera prescrição dos aspectos formais do texto traduzido (Bunge, 2000). Na visão do positivismo tradicional, a leitura se considerava um processo literal, que se baseia na decodificação palavra por palavra isoladamente do seu contexto (DUBOIS, 1987).

Nos anos de 1960, pelo avanço da tecnologia da comunicação, surgiram os estudos do texto para integrar, na análise da linguagem, a categoria "contexto" cujo conceito deixa de ser meramente linguístico formal para abranger a situação comunicativa que engloba o texto e os conhecimentos prévios do leitor. Nesta abordagem comunicativa, a leitura é vista como interação dinâmica (TOBÓN DE CASTRO, 1991).

Nessa época, o tradutor estadunidense Eugene Nida (1969) escreve várias pesquisas sobre a tradução da Bíblia e o contexto sociocultural da sua recepção. Nida cunha o termo equivalência dinâmica, categoria importante na descrição dos textos traduzidos. As equivalências dinâmicas partem da interpretação das expressões culturais do texto original em detrimento da sobrevida da sua tradução na cultura receptora da tradução.

Na década de 1970, entra na moda a perspectiva cognitiva e pragmática da linguagem. Os estudos focaram mais no uso e na recepção da linguagem como discurso e como texto. A visão pragmática discursiva abrirá caminho para o estudo da semiótica da tradução. Com as teorias do discurso, Hatim e Mason (1990) passam a analisar as traduções de textos comunicativos com base em três fatores: o texto, o autor/o tradutor e o leitor (o contexto de recepção).

Na mesma época, na Escola Superior de Intérpretes e Tradutores (ESIT) na Universidade Paris III (Sorbonne Nouvelle) foi desenvolvida a teoria interpretativa que estudava o tradutor como leitor e como escritor. Esse modelo explica que a tradução passa por três fases: codificação do texto-fonte, reimaginação do seu sentido e, finalmente, a reformulação do texto-fonte na língua de chegada. 
Posteriormente, os estudos da tradução passaram a focar cada vez mais a análise cognitiva e intercultural do tradutor. Jean Dancette (1995, citada em Emma Rodríguez, 2003) realizou estudos psicolinguísticos sobre a leitura do tradutor de textos informativos. A partir de uma ótica filosófica literária, George Steiner expõe no seu livro After Babel (1975) o processo hermenêutico das leituras do tradutor do texto original.

Mais tarde, a tradutologia passa do estudo do texto traduzido para análise sociológica do destinatário da tradução. Venuti (2000) estuda a recepção literária, social e cultural das traduções como fenômeno editorial e sociopolítico na cultura alvo. Venuti também faz distinção entre as teorias instrumentalistas, que reduzem a tradução a aspectos meramente formais e as teorias hermenêuticas que estudam a tradução como um fenômeno social.

Assim, a pesquisa em estudos de tradução mudou cronologicamente da abordagem textual, passando pelos estudos da recepção e chegando, finalmente, aos estudos do tradutor. Tentaremos identificar no texto traduzido marcas deste processo hermenêutico (transcultural e ideológico). Neste sentido, Milton Hatoum (2010) ressaltou:

Os tradutores são leitores muito especiais. Primeiro porque são leitores que já leem o livro pensando na tradução. Eles têm que ler duas, três, ou várias vezes o livro. Já é uma leitura interessada, uma leitura em filigranas. Esse leitor-tradutorescritor já tenta perceber desde a primeira leitura as nuances, as sutilezas, e as dificuldades que ele vai ter. A tradução pode transcender o original e sugerir coisas que não existem explicitamente no original. Ela pode dar, às vezes, até mais consistência ao original.

Hoje em dia, a tradução está inscrita no contexto das mobilidades transculturais como: "um trabalho argumentativo de imaginação epistemológica e de imaginação democrática presente nas reflexões e preocupações de todas aquelas perspectivas, movimentos e práticas que propõe o objetivo de construir novas e plurais formas de emancipação social" (SANTOS, 2005:168). 
Figura 20: Evolução dos estudos da tradução: dos estudos formais da tradução até os estudos discursivos da atividade do tradutor (Bastin,1998)

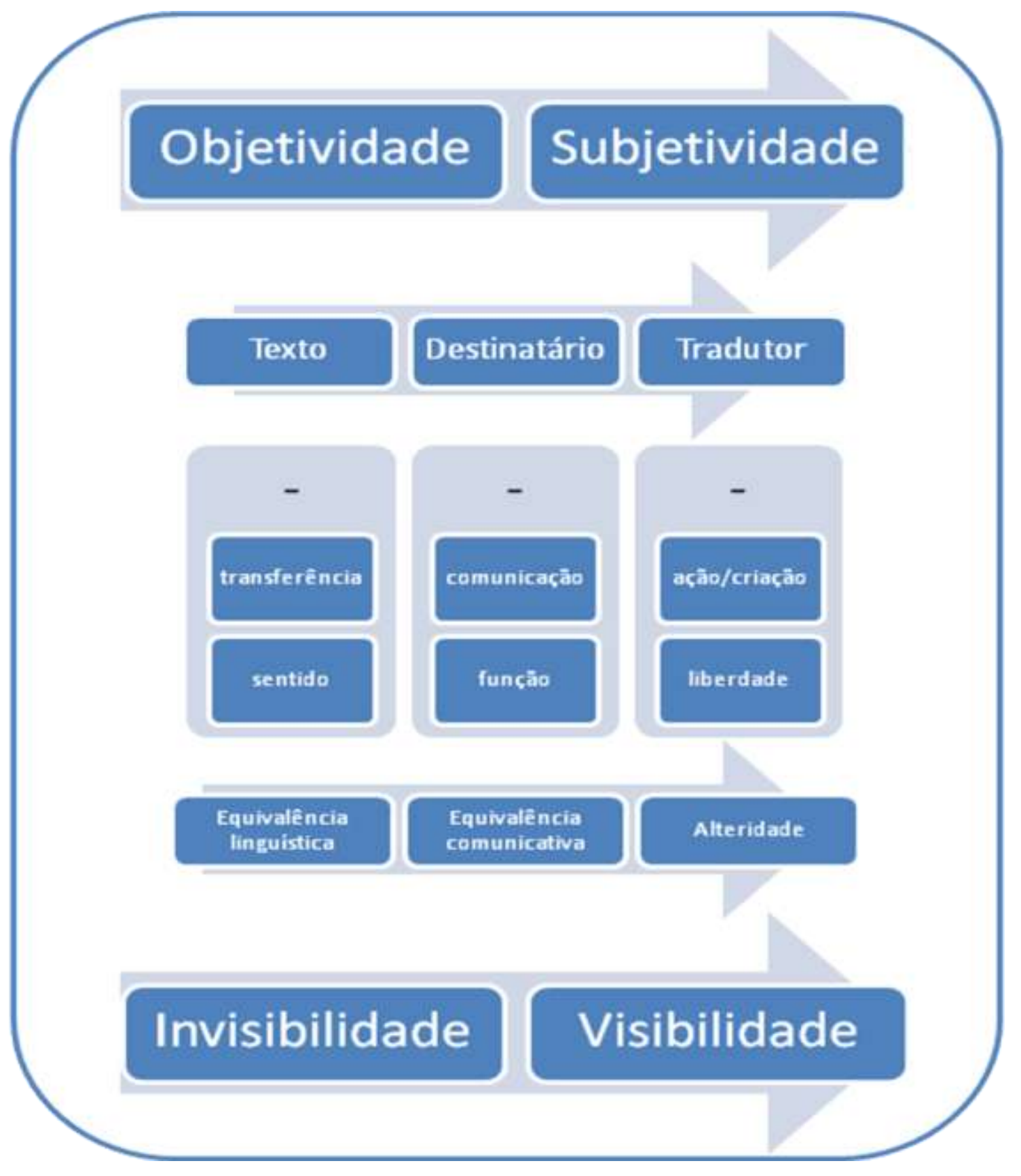




\subsection{Hermenêutica do tradutor}

Nos estudos literários aparece a hermenêutica moderna - que significa interpretação, em grego - durante o romantismo com F. Schleiermacher (1768-1834) como um método de compreensão e de conhecimento de fenômenos textuais através do diálogo. Schleiermacher (apud VENUTI, 2004) usa o termo "círculo da compreensão" para se referir à detecção da relação entre os aspectos psicológicos do autor, por um lado, e os fenômenos linguísticos do texto, por outro lado. No século XIX, Dilthy Wilhelm (1833-1911), seguidor de Schleiermacher, destaca a importância do contexto histórico para o estudo da hermenêutica e para compreender o comportamento dos fenômenos dos textos atuais.

Em seu livro Ser e Tempo (1927), Martin Heidegger (1983 ) explica que o modo de estar no mundo, chamado Dasein, comporta-se de forma análoga à linguagem escrita e ao seu círculo hermenêutico, que é construído no encontro entre o sujeito, cujo contexto do conhecimento prévio representa a parte, e o texto, que encarna o todo. Gadamer (1900-2002), discípulo de Heidegger, explica em seu livro Verdade e Método (1977) identifica no encontro entre o horizonte do conhecimento do leitor e o conhecimento do texto um diálogo que leva à fusão de horizontes e ao estabelecimento da verdade hermenêutica.

Paul Ricoeur (2011) critica a aparente oposição entre interpretação e comunicação no modelo de movimento hermenêutico de Steiner, porque para o autor francês são processos inseparáveis, traduzir é compreender. A compreensão se dá através do choque da comparação do incomparável. Isso envolve uma complexa prova do estrangeiro na experiência da produção do sentido amplo do texto a traduzir. Trata-se de um diálogo transcultural (interno- dentro da mesma cultura e externo- entre sua cultura e a cultura do texto a traduzir). Ricoeur (2011) aponta para um diálogo entre as lembranças da memória histórica e a tomada de consciência das diferenças (o estrangeiro) e das semelhanças (o próprio). O tradutor tem de ter o valor e a hospitalidade linguística de atravessar a fase de resistência do texto original à tradução para "o alargamento do horizonte da sua própria língua". Defende que há "um texto terceiro inexistente universal" que se retraduz em duas formas linguísticas (texto de partida e outro de chegada). Para ele, traduzir é "dizer a mesma coisa de outro modo". 
Distanciando-se da leitura de significados isolados do seu contexto, a perspectiva hermenêutica envolvia a leitura de textos no seu contexto. Assim, o hermeneuta é aquele que se dedica a interpretar e revelar o sentido das mensagens, para evitar mal-entendidos. Nesta pesquisa identificamos no texto marcas do processo hermenêutico das leituras e da interpretação transcultural. Uma hermenêutica intercultural envolve um diálogo intersubjetivo permanente com os outros dentro do texto e fora dele. Seguindo Nietzsche (apud MIGLIARI, 2010), trata-se de uma hermenêutica transcultural que sai da perspectiva do eu e se coloca nos lócus históricos dos outros para ter um olhar heteroperspectival sobre o objeto do estudo.

De acordo com Williams \& Chesterman (2002), os estudos da tradução pesquisam três processos:

1. Hermenêutica do tradutor, ou seja, a semântica das unidades do texto traduzido, produzida a partir de leituras, interpretação e compreensão.

2. Retórica do tradutor, ou seja, a estilística do discurso traduzido, produzido por meio da recriação e da reexpressão. Nesta mesma linha se pesquisa a "traduzibilidade" que se refere às mudanças que pode sofrer o texto-fonte durante a tradução e a relação indeterminada da equivalência entre as duas línguas e a interpretação contextual do sentido. $\mathrm{O}$ estudo da traduzibilidade analisa também o grau da significação entre uma língua e outra e da dificuldade da tradução. Esse grau vai depender do tema e seus aspectos linguísticos (sintáticos e léxicos) e extralinguísticos (idiossincrásticos e realidades distintas); da situação comunicativa, e da perspectiva espacial com suas três dimensões (geografia, flora e fauna) (PYM, apud BAKER, 1998). Assim, podemos pensar na traduzibilidade em dois planos: o texto a ser traduzido e o texto que resultará da tradução (PALUMBO, 2009).

3. Sociologia do tradutor ou pragmática da tradução: publicação da tradução e sua recepção. A literatura brasileira e a árabe, apesar de sua riqueza e das muitas semelhanças entre as duas culturas, ainda carecem de contato e conhecimento mútuo. Um meio de sanar esse hiato são as traduções e os estudos interculturais. Pensando na proximidade entre tais mundos linguísticos, decidimos estudar língua portuguesa e 
literatura brasileira. Atravessamos os obstáculos linguísticos para poder traduzir para o árabe Relato de um certo oriente, de Milton Hatoum.

Figura 21: Três momentos do processo da tradução (Maged El Gebaly, 2011).

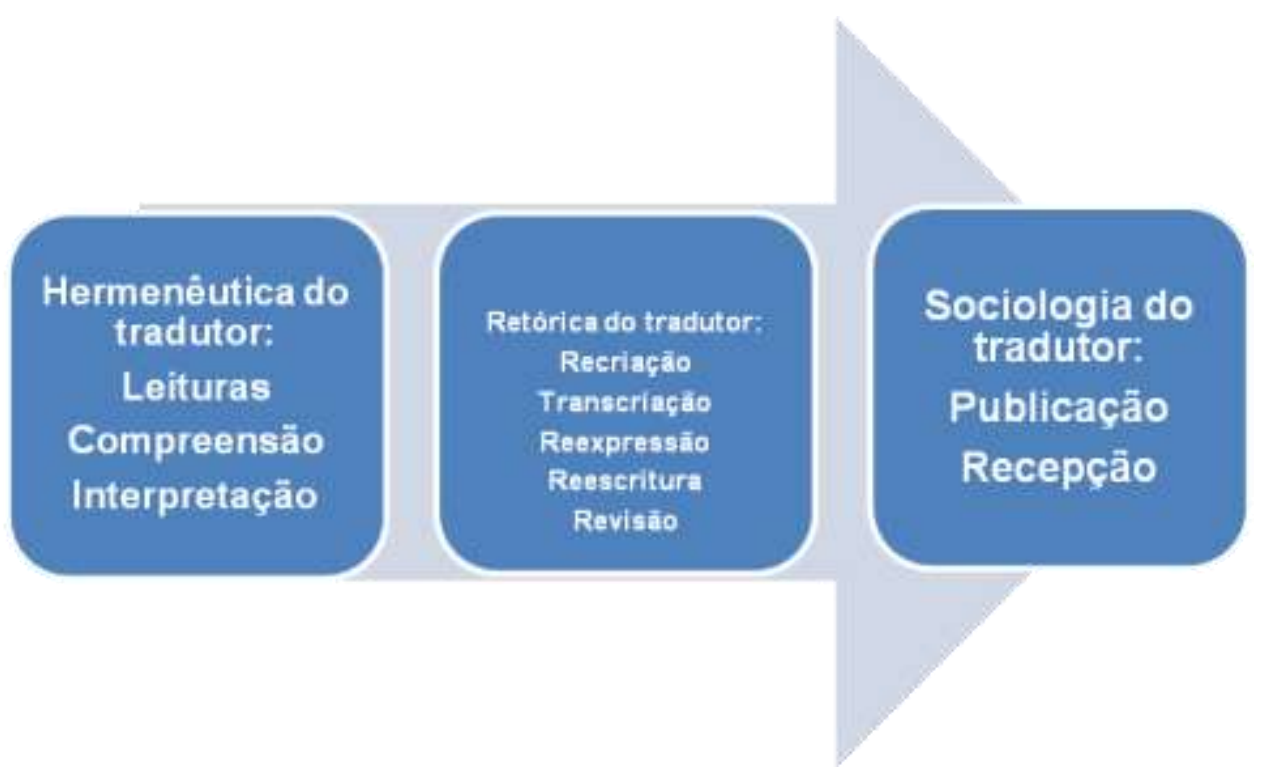

George Steiner em seu livro After Babel: Aspects of Language and Translation (1975) aborda os dois primeiros processos (interpretação e recriação), denomina-os como movimento hermenêutico e os define como atos que realiza o tradutor literário quando faz a transferência de um texto de uma língua para outra para a extração do sentido e para a compreensão do texto. ${ }^{14} \mathrm{O}$ movimento hermenêtico ocorre em quatro etapas que compõem os dois processos da hermenêutica do tradutor:

\footnotetext{
${ }^{14}$ Entendemos por tradutor literário aquele sujeito bicultural e conhecedor da literatura do texto de partida e domina a reescrita recriativa na língua de chegada (HURTADO ALBIR, 2001).
} 


\subsubsection{Interpretação}

A primeira etapa desta fase é a confiança inicial do tradutor, que parte de duas fontes:

Uma interna: que é a confiança na sua capacidade de compreensão do texto-fonte. Como o texto literário é uma obra aberta de caráter criativo e de estruturas polissêmicas, à diferença de outros tipos de tradutores, o literário precisa de habilidades de leituras e de um saber "enciclopédico" para poder compreender e interpretar as estruturas poéticas e intertextuais das diferentes experiências literárias e discursivas. Tais experiências são polivalentes, isto é, constituídas cognitivamente de múltiplos sistemas de valores estéticos e éticos (ECO, 1962, 1973).

Outra fonte externa dessa confiança vem determinada pelos agentes sociais e culturais e pelas condições socioeconômicas, porque estes agentes determinam as normas que regem a interpretação do texto traduzido. O tradutor parte da sua posição ideológica no campo cultural da circulação do texto traduzido. As tendências do poder simbólico nas relações culturais nacionais e internacionais e o papel supostamente inovador ou conservador da tradução dentro da cultura receptora regem de modo invisível os próprios critérios ideológicos de seleção de obras a serem traduzidas (BOURDIEU, 1995, SIMEONI, 1998, GOUVANIC, 2005):

Among the main reasons for the loss of the text's original significance in its "new" field of production is that the transfer from one national field to another is performed through a number of social operations. The article ("Les conditions socials de la circulation international des idées" de Pierre Bourdieu) reflects on such operations- selection, classification and reading...Translated materials are acknowledged as forming a part of the selection process-they provoke relevant questions within the cultural field, e.g., which works will be translated from the original field, who will translate, and publish them, and whose interests are involved (BOURDIEU, 1990; MEYLAERTS, 2005).

A segunda fase é decifração e compreensão da linguagem do texto. $O$ tradutor decodifica o contexto formal e interpreta o incompreensível a fim de chegar ao sentido do texto. Para compreender, o tradutor entra em diálogo e cooperação com o texto, tentando situar-se numa extraposição, ou seja, imaginar-se na posição transcultural do escritor para poder interpretar a linguagem carnavalesca e heterogênea do texto literário, como afirma Kristeva (1969) “... todo 
texto se constrói como mosaico de citações, todo texto é absorção e transformação de outro texto" (BAKHTIN,1984).

Assim, essa interpretação acontece numa fase analítica intermediária entre as leituras e a tradução chamada "meta-texto", definida como o lugar da leitura poética das conexões formais da coesão do texto e a representação mental das suas relações semânticas com outros textos e contextos (SELESKOVITCH e LEDERER, 1993, JEANNE DANCETTE, 1995, citada em EMMA RODRÍGUEZ, 2003). Nesta fase, o tradutor pode identificar os intertextos, ou seja, os diálogos culturais entre o texto-fonte e outros textos ou representações sociais que o precedem ou giram ao seu redor (BASSNETT, 1980, MOSCOVICI, 2000).

No processo de interpretação das diferentes situações sociais no texto, os episódios das experiências pessoais do tradutor se ativam. O tradutor detecta os diferentes roteiros das situações representadas por sequências de acontecimentos e ações dadas em lugares e tempos determinados (SCHANK E ABELSON, 1977). Ele infere o não dito explicitamente. O tradutor constrói pouco a pouco a representação mental da intencionalidade do autor e do contexto dos esquemas e dos roteiros mentais da comunidade do texto. A atitude do tradutor perante o texto-fonte depende do imaginário que ele tem da cultura do original e da cultura receptora da tradução, assim como a situação da cultura do original perante a cultura do texto alvo. (CARBONELL, 1997). Nessa contextualização mental do texto-fonte, os diferentes graus de acesso aos contextos dão diferentes interpretações, o tradutor seleciona ideologicamente uma. (RUIZ MONEVA, 1998). No mesmo sentido, Milton Hatoum afirma na nossa entrevista (2010) que “é importante também contextualizar a obra. Não ler apenas o livro que se vai traduzir, mas os outros livros do autor a ser traduzido".

\subsubsection{Recriação na reescrita}

Na sua entrevista conosco, Milton Hatoum (2010) afirma:

O melhor tradutor literário é um bom escritor. Mesmo que ele não seja um escritor de ficção ou um poeta. Um bom tradutor literário tem que ter primeiro o domínio de sua própria língua, como se ele fosse capaz de escrever a ficção que está traduzindo. 
Uma vez captado o texto, o tradutor passa ao terceiro estágio, que é a apropriação e incorporação do sentido do texto-fonte na língua alvo. O tradutor analisa as representações da crítica social do texto-fonte e da cultura receptora. (VAN DIJK, 1999). Na análise, o tradutor vai achar o "archisema", ou seja, o sentido invariável entre o texto-fonte e o texto alvo que contém sentidos traduzíveis chamados "transemas" (VAN LEUVEN-ZWART, 1991, citada em ENANI, 2005). Nesse processo, o tradutor terá que transportar para a língua meta outros sentidos intraduzíveis, por isso, a tradução literária tornou-se uma "reformulação", "recriação" ou "transcriação", ou seja, uma releitura do texto-fonte para apropriar-se dele e recriá-lo para a cultura receptora (HAROLDO DE CAMPOS, 1992).

A transcriação revela que o tradutor lê o texto de uma posição que expressa suas representações e seus esquemas sociais e literários nas diferentes situações que constituem a estrutura global coerente do texto (SUSSAN BASSNET, 1991; THEO HERMANS, 2010). O tradutor contrasta o esquema do texto com seus próprios esquemas (ANDERSON, 1977). Ele evoca a "transfusão" de dois horizontes: o do seu conhecimento prévio da literatura receptora e o horizonte das representações das referências das novas situações no texto-fonte (GADAMER, 1977; HAROLDO DE CAMPOS, 1981). Ele vive frequentemente na intersecção de redes culturais nas grandes cidades e tenta identificar as representações sociais do contexto de recepção da sua tradução e termina incluindo na interpretação, consciente ou inconscientemente, sua cosmovisão de convicções e crenças pessoais e sociais, manifestando no seu trabalho marcas interculturais e híbridas, resultado da sua interação com o lugar onde ele está (MASON, 1994; PYM, 1998).

O tradutor, por um lado, pode incorporar o texto-fonte na cultura meta com a contextualização do texto-alvo por meio da domesticação ou da apropriação (CLARAMONTE, 1997). Esta contextualização manifesta a intencionalidade do tradutor em inovar ou conservar valores culturais, estéticos ou poéticos na cultura de chegada. Por outro lado, o tradutor pode focar o exótico da cultura meta através da estrangeirização, para responder aos estereótipos dos seus leitores produzindo uma leitura "orientalista" do texto-fonte diferente do efeito que tem a obra literária na sua cultura de origem (CARBONELL, 1995).

Finalmente, na quarta fase, o tradutor conserta qualquer possível desequilíbrio entre o sentido do texto-fonte e o do texto-alvo recorrendo à restituição e compensação de alguns 
componentes. Ele até pode intervir no texto com mudanças, como a adaptação. Tais mudanças são fruto da interpretação livre do texto e das representações sociais do contexto cultural e ideológico da sua produção e da sua recepção. As ideologias, por sua vez, estão relacionadas com os grupos sociais que patrocinam a tradução e a sua publicação.

Em seguida, apresentaremos o processo da interpretação do tradutor literário de narrativa, objeto do presente estudo. Este processo começa com a confiança inicial do texto original, passando pela sua decodificação e compreensão, e chegando finalmente até sua apropriação e sua incorporação na cultura-meta.

\subsection{Conarração do tradutor literário}

Uma boa tradução deve ser ao mesmo tempo literal e livre. Berman afirma que a tradução deve passar pela experiência e pela reflexão, pois a tradução, como ele diz, é sujeito e objeto de um saber próprio. Por isso é difícil...Uma boa tradução deve ser ao mesmo tempo inventiva e próxima do significado do texto original, porque você não pode distorcer aquilo que está no original, mas ela tem que fluir. Então o difícil da tradução é esse fluir. (Milton Hatoum, 2010).

Este fluir nos remete ao conceito do movimento hermenêutico da tradução literária da narrativa. É preciso analisar o texto original e fazer uma análise comparativa das semelhanças e diferenças entre ele e o texto traduzido, pensando que este movimento hermenêutico na tradução também envolve as seguintes etapas:

O tradutor do romance adquire confiança na obra conhecendo as características estilísticas da escrita do autor e da sua tradição literária. Entre a subjetividade do tradutor e o autor-narrador se cria, pouco a pouco, uma intersubjetividade solidária e o tradutor vai identificando o momento histórico da produção do autor. O tradutor sente afinidade com o texto; ele lê e se adapta ao autor para poder interpretar as implicações e as associações da narrativa. Assim, o tradutor se aproxima cada vez mais das representações do autor nos níveis sociolinguísticos dos registros, ou seja, nos diferentes usos da linguagem e no nível temático das metáforas literárias porque compreendeu os problemas da subjetividade criadora da obra (VENUTI, 1995). O tradutor reconhece a história anedótica, ou seja, o conjunto de todos os seus acontecimentos, a estrutura diacrônica da história literária e da situação narrativa, o contexto e o ato narrativo que enuncia a história. $\mathrm{O}$ tradutor decodifica dentro de um nível macroestrutural do discurso narrativo as referências e as marcas 
culturais que permitem identificar o sistema axiológico do romance nas relações da história e nos temas dos ritos, das categorizações, das convenções dos modos de fazer e de dizer e dos papéis socialmente instituídos no sistema sociocultural e na abordagem das hierarquias e estratos no sistema sócio-político do romance (PRADO BIEZMA, 1983).

Como leitor, o tradutor se situa no tempo e no espaço do romance para tornar inteligível todo o contexto geral da ação da narrativa. Por essa razão, o tradutor vai decodificando expressões típicas das variações do tempo e do espaço nos quais ocorre a história literária, e assim é capaz de entender o desenvolvimento lógico dos acontecimentos (MIKHAIL BAKHTIN, 1984). O tradutor desenvolve cuidados especiais na tradução destes lugares do texto: o título, o início e o final da obra e ou dos capítulos, visto que são, de fato, relevantes porque ocupam posições de abertura ou de encerramento semântico. Muitas circunstâncias sociais, econômicas e culturais do autor determinam a tradução dos lugares iniciais e finalizadores dentro de uma obra literária (ECO, 1979; HERMANS, 2010).

A transferência de técnicas narrativas, por sua vez, diz respeito ao processo de interpretação do tradutor para facilitar a obra para os leitores e à análise das vozes narrativas, dos diálogos, dos monólogos e das descrições. Os caracteres em geral, e o herói do romance em particular, são das principais técnicas de transmissão das hierarquias axiológicas que dão sentido ao valor simbólico e cultural do romance. A leitura do tradutor considera os personagens dentro da estrutura global do texto e vê neles representações de maneiras de ser e de fazer, que se manifestam na sua linguagem e na sua cultura. $O$ tradutor também vai decodificando as diversas formações discursivas dos personagens que marcam suas identidades culturais e sua pertinência social (idioletos) (HAMON, 1997; HURTADO ALBIR, 2001).

O tradutor tenta arrumar qualquer possível desequilíbrio entre o significado do texto original e do texto traduzido, como a tradução cuidadosa dos seguintes lugares do texto: o título, o início e o final da obra ou dos capítulos, que ocupam posições de abertura ou de fechamento semântico. Muitas circunstâncias sociais, econômicas e culturais determinam a tradução das partes iniciais e finalizadoras da obra literária (ECO, 1979; HERMANS, 2010).

A interpretação do tradutor literário de narrativa é um processo semiótico localizado na cultura do texto traduzido para transferir a mensagem de texto original. Neste processo, vamos 
identificar as intervenções do tradutor no nível microtextual (expressões lexicais, de frases, gramaticais, etc.) para chegar à interpretação dos aspectos macrotextuais da tradução como o contexto histórico e ideológico da cultura de chegada da tradução.

\subsection{Identificação da hermenêutica do tradutor}

Explicamos que em 1975, George Steiner propôs que o movimento hermenêutico da tradução elucida as seguintes fases:

Figura 22: Movimento hermenêutico da tradução de George Steiner (1975), gráfico por Maged El Gebaly (2011).

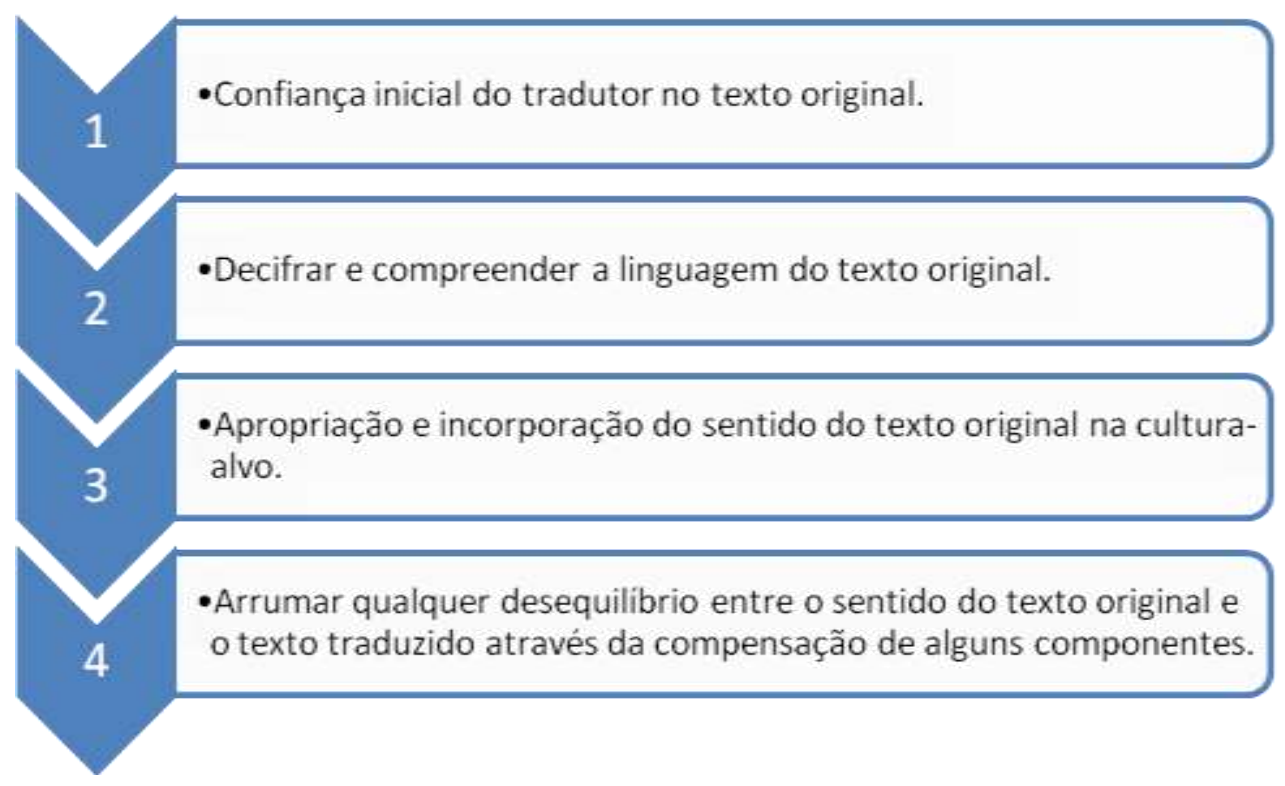


Em nosso estudo propomos um modelo para a identificação deste movimento hermenêutico do tradutor no texto traduzido.

Figura 23: Identificação do movimento hermenêutico do tradutor (Maged El Gebaly, 2011)

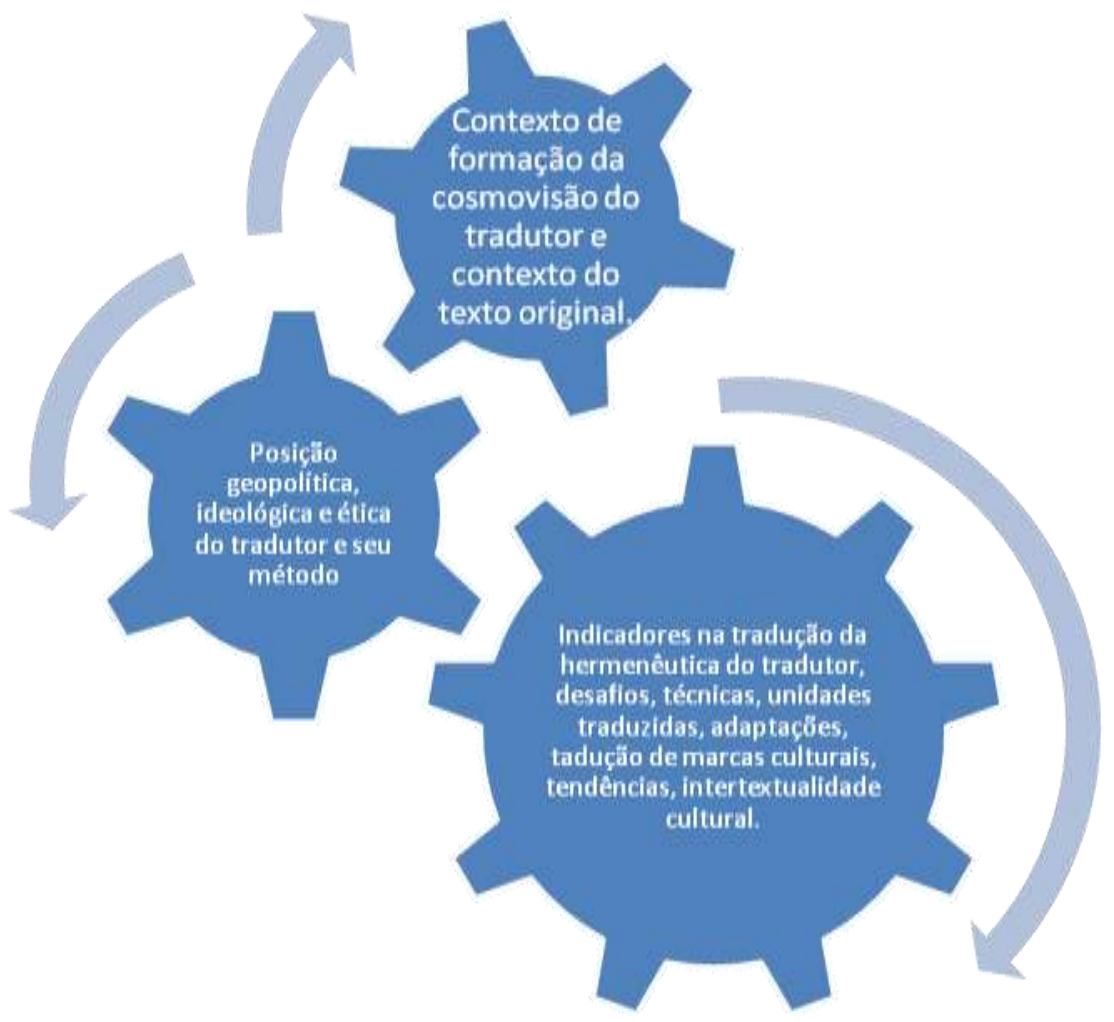

Nesse modelo, a interpretação do tradutor parte da sua posição geopolítica, ética e ideológica, que bebe posição de dois contextos: o da formação da cosmovisão do tradutor e o do texto-fonte. Esta hermenêutica se manifesta no texto traduzido através de certos indicadores, como o prólogo, a nota do tradutor, os problemas, as técnicas, as equivalências, as adaptações, as equivocações, os erros, as tendências na tradução e os intertextos culturais.

Para identificar a experiência interpretativa, localizamos e analisamos as variáveis que são influenciadas pelas leituras, como o processo de elaboração das unidades de tradução, e especialmente, as intertextualidades culturais. 


\subsection{Análise da tradução}

À primeira instância, adotamos o conceito de "tradutor" aquele sujeito transcultural, ideológico (VENUTI, 1992) e literário (OCTAVIO PAZ, 1971) que é hermeneuta dos sentidos dos textos e de seus contextos interculturais e sociais (STEINER, 1975).

A língua portuguesa, bem como a língua árabe, são marginalizadas no sistema cultural internacional, em que predomina a língua inglesa. A literatura brasileira e a árabe, apesar de sua riqueza e das muitas semelhanças entre as duas culturas, ainda carecem de contato e conhecimento mútuo. Um meio de sanar esse hiato são as traduções e os estudos interculturais.

A ausência de contato acadêmico e de diálogo direto entre as duas culturas dá margens para o surgimento de estereótipos e preconceitos que se acentuam com a parcialidade midiática na transmissão de notícias e informações acerca dos países árabes. É preciso dar voz para que brasileiros e árabes possam verdadeiramente se conhecer e quebrar os conceitos orientalistas que surgem como consequência do distanciamento. Ainda que o Brasil tenha recebido um número grande de árabes como imigrantes. De acordo com o Censo 2008 divulgado pelo IBGE, 4,5\% da população brasileira diz ter origem "do oriente médio, síria, libanesa e armênia". A pesquisa do IBGE pressupõe uma diversidade entre os árabes e descendentes no Brasil. Apesar de a maior parte dos imigrantes árabes serem de origem libanesa ou síria, há uma menor porcentagem de palestinos, egípcios e marroquinos.

Por um lado, no imaginário do brasileiro a respeito dos povos árabes ainda persiste a ideia de homogeneidade, em que as diversidades culturais não existem. Ideias do comerciante inato, bom amante, sedutor, machista, são recorrentes na fala de muitas pessoas quando se referem aos árabes. Parte desses estereótipos estão relacionados a imagem sempre negativa passada pela mídia e parte se dá pelo próprio contato com os "mascates", que batiam nas portas das famílias para vender toda sorte de coisas. Para o imigrante ou descendente, por outro lado, ficou a saudade de sua terra, misturada à nova rotina e à nova língua. Vamos agora à análise da cadeia comunicativa do projeto de tradução do Relato ao árabe. 


\subsubsection{Problemas e técnicas de tradução}

Ou o tradutor deixa o autor em paz e leva ao leitor até ele; ou deixa ao leitor e leva ao autor até ele.

SCHLEIERMACHER, Berlín, 1838 (apud VENUTI, 2004)

Traduzir o Relato implica, às vezes, na transferência, certas mudanças do olhar do descendente. Por isso, a tradução é uma missão emancipatória das hegemonias culturais e da ruptura com os padrões de estética europeia estabelecidos no inconsciente coletivo dos povos. Ao longo do processo experimental da tradução do Relato, encontramos os seguintes problemas:

\subsubsection{Desambiguação da polifonia}

A narração em voz feminina cabe em português e em árabe, não cabe na língua inglesa. Por isso a poetisa americana tradutora do Relato, Ellen Watson, não encontra outra solução além de assinalar essa feminilidade ao início da tradução do primeiro capítulo do Relato com a frase “A woman speaks". Na nossa entrevista com Milton Hatoum (2010), o autor nos adverte do problema da ambiguidade que encontrou a tradutora alemã do Relato:

A minha tradutora alemã Karin von Schweder-Schreiner me disse uma coisa interessante : "por trás dessas frases límpidas, aparentemente simples que você constrói, há uma dificuldade imensa. Eu encontro uma dificuldade para traduzir o livro porque, às vezes, para um tradutor alemão, a falta de precisão do português do Brasil pode confundir um pouco e dificultar a tradução ". Por exemplo, quando não se usa no começo da frase o pronome pessoal ("ela via, ele disse") o tradutor pode confundir o sujeito da frase.

Exemplo: Na p. 33 do segundo capítulo, “Quando apontava para o céu escuro e dizia "é a luz da noite", enfrentamos o problema da ambiguidade do sujeito do verbo ("apontava... e dizia" quem? Ele ou eu?). Na tradução árabe marcamos o sujeito como eu “eu apontava... e eu dizia...”. 


\subsubsection{Identificação e codificação de vozes misturadas}

O tradutor como Emilie tem que navegar entre todas as vozes misturadas para poder recriá-las no texto traduzido.

\subsection{Identificação}

Identificação de uma voz no monólogo narrativo (quem fala e como fala) e distingui-la das outras vozes por meio das aspas do discurso direto e também das implicações da situação implícita da condição surda-muda da personagem Soraya Ângela, assim como nas pp. 16 e 17 do primeiro capítulo o sujeito da frase "não podia falar" refere-se ao pronome "eu" e não ao “ele/ela". Exemplo: Na mesa, à hora das refeições, tu e Soraya eram servidos pelas mãos de Emilie, sempre em movimento: descascando frutas, separando os alimentos para cada um de vocês, mas tu já podias negar ou aceitar a comida com poucas palavras, como monossílabos, enquanto Soraya resignava-se a afastar o prato, negacear com a cabeça ou curvá-la em direção ao prato, às vezes olhando para ti, para tua boca, talvez pensando: "Quando me faltou a palavra?", ou pensando: "Em que momento descobri que não podia falar...", talvez vexada porque tu, com a tua pouca idade, já eras capaz de construir frases mal acabadas, fracionadas, desconexas, é verdade, mas com um movimento dos teus lábios, alguém reagia, alguém movia os lábios, o mundo ao teu redor existia."

\subsection{Codificação}

Na codificação terminamos desenvolvendo um olhar contrastivo entre a escrita em árabe e em português. Exemplo: A tendência discursiva do português a usar muitas vírgulas, em comparação com o árabe, que tem às vezes frases longas entrelaçadas com conectores. Outro exemplo: Na p. 64 do terceiro capítulo: “Até Emilie e o teu tio Emílio notaram o meu assombro. Senti no rosto um vazio, como se tivessem vendado meus olhos...”. O tradutor tem que estar atento à conjugação verbal árabe dos verbos "notaram" e "tivessem vendado" com o sujeito dual marcado na língua-alvo. Porque em português não tem marca da dualidade dos sujeitos "Emilie $\boldsymbol{e}$ o teu tio Emílio". 


\subsubsection{Decifração dos modos verbais das vozes narrativas}

Como na decifração da escritura do antigo egípcio, tentamos extrair o sentido de uma escrita ininteligível, a partir de várias leituras e inferências de significados contextuais. Exemplo: Na p. 34 do segundo capítulo: "Emilie ajoelhou-se a seus pés e a Irmã Superirora intercedeu: que partisse com o irmão, Deus a receberia em qualquer lugar do mundo se a sua vocação fosse servir ao Senhor.". Para a tradução árabe, recorremos à técnica da descifração para compreender o modo verbal da narrativa: a voz do Hakim "Emilie ajoelhou-se..." e a voz da Irmã Superiora em "que partisse...".

\subsubsection{Especificação semântica}

Compreender o contexto narrativo permite especificação semântica obrigatória na tradução do léxico ao árabe. Exemplos: Na p. 9 do primeiro capítulo, "criança" é uma palavra feminina em português que se refere aos dois gêneros. Em árabe, há masculino "menino" e feminina "menina" para a palavra criança. Por isso, optamos por "طفلة", definição do sentido adequado ao contexto narrativo da palavra criança, que remete à lembrança da relatora da sua infância.

Na p. 71 do quarto capítulo "Um tio meu, Hanna" e mais adiante na p.73 do mesmo capítulo "O mais imaginoso entre os irmãos do meu pai;...”, o escritor define que Hanna é o tio do pai do narrador.". Na tradução árabe tem que especificar semanticamente se é o tio paterno ou materno. Da situação narrativa inferimos que faz referência aos irmãos do pai, tios do lado do pai, e se diz em árabe em uma palavra só "أعمامي".

\subsubsection{Tradução das referências culturais}

Aubert (2006) reflete sobre a dificuldade da delimitação da referência cultural, porque não é perceptível na expressão linguística tomada em isolamento, nem se encontra confinado dentro do seu universo discursivo original. Segundo o autor, o marcador cultural se torna visível (e, portanto, se atualiza) se esse discurso original (a) incorporar em si uma diferenciação ou (b) for colocado em uma situação que faça sobressair à diferenciação das alteridades (AUBERT, 2006, p. 32-33). Na proposta, Aubert (2006) classifica os marcadores culturais em quatro domínios: 1) 
o ecológico, que designa seres, objetos e eventos da natureza 2) o da cultura material, que designa objetos criados pelo homem, 3) o da cultura social, que designa o próprio homem, bem como as atividades e eventos que estabelecem, 4) o da cultura ideológica: que designa crenças. Para poder traduzir essas marcas culturais no Relato, nos valemos das seguintes técnicas:

\subsubsection{Visualização}

A visualização é a representação mental de imagens das informações narradas para poder traduzir as referências que não constam em dicionários bilíngues.

Exemplos:

-A visualização de "casarão", marca cultural material na p. 19, e a busca do equivalente da palavra que dista de palavras do mesmo campo semântico usado no texto de Hatoum como sobrado, casa, casarão e palafita;

- A visualização da imagem da fonte "Jorros d’água da boca de pedra dos anjos" na p. 24 do primeiro capítulo;

- A visualização das imagens de "gruta" e de "caramanchão" na p. 9 do primeiro capítulo: "Ingressado numa espécie de gruta vegetal, entre o globo de luz e o caramanchão que dá acesso aos fundos da casa... continuou imóvel, com o olhar perdido na escuridão da gruta...”.

\subsubsection{Explicitação discursiva}

Uma das diferenças culturais apontadas por Darcy Ribeiro (1999) em seu ensaio é entre cidade e campo (no Relato, Manaus versus Interior/Paris versus Marselha e Beirut). Diferença que tem que ser muitas vezes explicitada na tradução árabe. Nesse sentido, a explicitação vem sendo aqui uma técnica muito necessária para introduzir informações implícitas para a desambiguação sintáctica ou semântica (PYM, APUD MONA BAKER, 1998). 


\section{Exemplos:}

- A partir da visualização do contexto narrativo, conseguimos na tradução árabe a explicitação discursiva da referência implícita ao sul do Líbano. Na p. 71 do quarto capítulo "Nas cidades litorâneas do sul".

- Na p. 15 do primeiro capítulo, a partir da visualização do contexto implícita do ambiente natural de Manaus, conseguimos explicitação discursiva na tradução árabe da humidade do ar do "sereno" pelo calor para distinguí-lo do sereno frio de outras regiões.

- Na p. 62 do terceiro capítulo “... falava uma algaravia...”. "Algaravia” se refere em português à “estranheza”, referência metafórica a qualquer língua estranha. A língua árabe o é para Dorner. Numa nota explicitamos a tendência estílistica do autor a usar palavras de origem árabe como "Algaravia", uma referência implícita à região "Algarve" em Portugal que significa, em árabe, "Oeste" de Al Andaluz no sul Portugal, governado pelos árabes desde 715 até 1492.

- Na tradução árabe da frase "caboclos recém-chegados do interior." na p. 35 do segundo capítulo, recorremos a uma explicitação discursiva do sentido regional de "interior", que refere em Manaus às partes altas do Rio Amazonas.

-Na p. 62 do terceiro capítulo, o escritor usou "igarapé", marca cultural ecológica, que significa em tupi "percurso da barca" ou "rio pequeno", recorremos a uma explicitação pragmática na tradução árabe da referência natural "Igarapé de Educandos" com a adição do sentido regional para que seja em árabe "percurso aquático de Educandos".

\subsubsection{Transliteração}

Apelamos na nossa tradução à técnica da transliteração como transcrição fonética ou grafêmica na transferência ortográfica de palavras da língua fonte para a língua de chegada, por meio de relações grafema-grafema biunívocas (HURTADO ALBIR, 2001).

Um exemplo: Nas pp. 12 "Praça do Diamante" e 28 "Nossa Senhora dos Remédios" do primeiro capítulo, recorremos à transliteração dos nomes próprios para o árabe, para preservar as marcas espaciais fixadas no Relato. Outro exemplo: Na p. 28, tivemos que fazer transliteração de 
"mascate" com uma nota que explica a carga cultural histórica da palavra, que vem originalmente da capital de Omã, país árabe que foi colonizado pelos portugueses em duas épocas (1507- 1580) e (1640-1650). Mascatear, verbo derivado de "mascate" se refere à atividade de vendedor ambulante que bate nas portas das famílias para vender toda sorte de coisas, muito comum entre os imigrantes de origem árabe que vieram ao Brasil. (PORTO, In: BERND, 2007, p. 421).

Terceiro exemplo: fizemos uma transliteração da marca cultural social "caboclo" na p. 35, e colocamos uma nota que explica que é uma palavra de origem tupi que se refere à mistura de indígena com europeu (DENIZ, In: BERND, 2007, p. 63).

\subsection{Entre a tradução literal de uma marca cultural social e o seu empréstimo}

Na p. 13 do primeiro capítulo, temos duas traduções árabes possíveis para a data festiva "Natal" - "عيد الميلاد"- literalmente em árabe Festa do Nascimento, que ambiguamente pode significar aniversário e pode referir-se ao nascimento de Jesus. Ainda que essa escolha represente resistência à tradução "كريسماس", empréstimo por meio da transliteração da palavra inglesa, "Christmas", que não deixa de ser um anglicismo incorporado de modo natural nas cerimônias de celebração do Natal em alguns países árabes como o Egito.

\subsubsection{Campo da tradução no Egito}

O movimento de tradução no Egito tem um papel importante nas mudanças culturais. Por isso, tentaremos explorar os momentos históricos relevantes deste movimento definido às vezes em termos geracionais. A geração é entendida aqui como "um sistema de ideias e valores que encerram um juízo interpretativo do passado, do presente e do futuro" (Álvaro Manuel Machado y Daniel-Henri Pageaux, 2001).

O primeiro momento foi depois da invasão de Napoleão Bonaparte ao Egito. Nessa campanha militar houve contato entre os egípcios e um sistema cultural francês moderno. Napoleão criou a Associação Egípcia de Ciência e levou grupo de cientistas e intelectuais para o estudo do Egito para poder colonizar esse país. Ele mandou a construir a primeira imprensa árabe no bairro de Bulaq no Cairo. Depois da saída dos franceses do Egito, os egípcios conseguiram 
levar o governo de Mohamed Ali (1805-1848) ao poder. Esse governante tentava construir um estado independente, e uma das formas de realizar esse objetivo foi a modernização do país via a industrialização e a tradução do inglês e do francês. Envia-se a primeira expedição egípcia para estudar na França.

Essa comitiva era presidida pelo célebre tradutor egípcio Rifaaa el-Tahtawi (1801-1873), que escreveu seus diários durante sua estadia em Paris comparando a vida francesa e a árabe. Em 1835 participaria da fundação da Escola Superior para a Tradução Al-Alsún (Línguas) para a formação dos primeiros tradutores. Rifaaa introduziu as ideias iluministas da França e aportou assim ao processo do Renascimento no Egito depois de tantos anos da dominação teocrática do Império Otomano. Traduziu do francês para o árabe vários livros de história, geografia e direito. Passou para o árabe a Constituição Francesa e arabizou o Direito Civil Francês. Escreveu uma metodologia para os egípcios para o estudo das obras literárias modernas.

No período de Ismail Pacha (1867-1879) começa uma onda de imigração de tradutores sírios e libaneses para o Egito, fugindo da teocracia otomana que limitava as liberdades de expressão na Síria e no Líbano. Na época, estava na moda a tradução da Literatura Francesa Clássica e Romântica. Mohamed Osman Galal traduziu Molière e Naguib Hadad traduziu Shakespeare.

Na primeira fase desse período havia uma corrente de tradutores, que influenciados pelo Al Azahar, Instituição Religiosa Islâmica, tendiam a arabizar o texto e exerciam certa censura sobre o texto-fonte e permitiam somente passar as expressões que cabiam na sua língua e ignoravam em certa medida as inovações literárias que podia levar da língua do Outro. Um exemplo desses tradutores foi Mustafa Lutfi el-Manfaluti (1876-1924). El Manfaluti, que pouco dominava o francês, arabizou François Édouard Joachim Coppée, Edmond Eugène Alexis Rostand, e Jacques-Henri Bernardin de Saint-Pierre.

Na segunda fase desse período havia outra corrente de tradutores que mantinham as inovações literárias e tentavam ser muito próximos dos estilos dos autores, como o caso da tradutora palestina Mai Zyada(1886-1941), radicada no Egito, que traduziu do inglês Sir Arthur Ignatius Conan Doyle (1859-1930) e do alemão Max Müller (1823-1900). Ahmed Hasan El Zayat (1885-1968) traduziu “Os sofrimentos do jovem Werther” de Goethe. 
Essa etapa relevante foi marcada por Taha Hussein (1889-1973), figura chave do Movimento Modernista Árabe - que ocupou o cargo de Ministro da Educação do Egito em 1950. Ele traduziu Jean Baptiste Racine, Voltaire, André Gide e Sófocles. Nessa época foi criada, em 1908, a primeira Universidade Moderna no Mundo Árabe e na África, a Universidade do Cairo, que participaria da criação de um público capacitado para a recepção dessa literatura traduzida.

\subsubsection{Tradutores da literatura latino-americana no Egito}

Após da independência do Egito em 1956, um dos desafios era tomar consciência das representações e dos diferentes modos de percepção utilizados pelo colonizador para controlar o povo egípcio. O fim de colonialismo não representaria somente dimensões políticas e econômicas, mas também psicológicas que afetam a própria formação narrativa das identidades do Egito. Esta relação entre o ideal colonizador e o real colonizado representava uma preocupação de parte dos intelectuais egípcios com os processos narrativos de legitimação do sistema de império do colonizador inglês.

Por isso, Taha Hussein prende o projeto de envio missões para Espanha, Alemanha, Itália e Rússia para o estudo de outras literaturas além das inglesas e francesas para criar uma ação cultural contrapontual ao centrismo anglo-francófono que exercia certo imperialismo cultural através das traduções. $O$ tradutor mais representativo desta época foi o célebre hispanista egípcio Mahmoud Ali Makki, quem traduziu grandes obras hispano-americanas como Dona Bárabara de Rómulo Gallegos.

Depois da revolução de 1952 no Egito, começou o boom literário dos escritores dos anos de 1960. Durante esta época muitos romances foram passados para o árabe. Durante essa

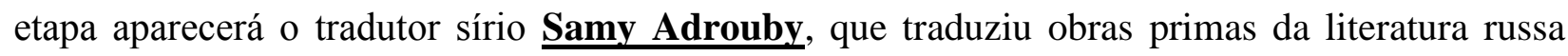
para a língua árabe, especialmente a obra de Dostoievski, como o romance Crime e Castigo, que

formaria parte da sensibilidade literária da época. É interessante mencionar aqui que Samy Adrouby foi o primeiro a traduzir Machado de Assis, já que passou o romance "Quincas Borba" do inglês para o para árabe.

Outro momento decisivo foi a agressão israelense aos territórios árabes em 1967, um acontecimento que daria o nascimento de movimento de escritores egípcios que tentavam sair 
dessa crise e reconstruir o Egito. Esse movimento será chamado Gallery 68. Um dos tradutores representativos desse movimento é o contista Mohamed Ibrahim Mabrouk, exemplo de um tradutor engajado com a tradução como ato político e humano estético, especialmente por representar uma corrente emergente da tradução da literatura latino-americana. No campo cultural egípcio competiam correntes culturais eurocêntricas: uma anglo-saxônica, outra francófona e ultimamente as espanholas, as italianas e as alemãs.

O tradutor Mohamed Ibrahim Mabrouk conseguiu abrir caminho para América Latina traduzindo contos latino-americanos do espanhol. Ele apresenta Gabriel Garcia Márquez no Egito com sua tradução do conto "O afogado mais formoso do mundo" e dá a conhecer Guimarães Rosa no contexto literário egípcio através da tradução do espanhol ao árabe dos contos "Os irmãos Dagobé" e "O cavalo que bebia cerveja”, de Primeiras Estórias. (MABROUK, 2007)

Depois, nos finais dos anos de1970 e do governo conservador de Sadat, a sociedade egípcia toma um rumo conservador. Aplica-se a política de perseguição aos intelectuais de esquerda e ao Movimento Estudantil. A situação econômica e cultural se abre para a saída de muitos egípcios para países de regimes conservadores como Arábia Saudita, que se esforçaria por aumentar o conservadorismo da sociedade egípcia.

Dessa geração, alguns viajam para Europa para estudar e entre eleso tradutor Mohamed Abuelata, formado na Espanha em Literatura Espanhola e Hispano-Americana que trabalha hoje em dia como professor da Universidade de Ain Shams. Abuelata introduziu no campo intelectual egípcio a história da narrativa latino-americana com sua tradução da "Trayectoria de la novela hispanoamericana actual: del realismo mágico a los años ochenta” de Villanueva, Darió y Viña Liste, José María. Abuelata foi também tradutor de contos de Gabriel Garcia Márquez, Jorge Luis Borges e Cortázar. Desta geração sobressai a Profa. Dra. Nadia Gamal Eddin, tradutora de Octavio Paz, Laura Esquivel e de vários dramaturgos latino-americanos.

\subsubsection{Tradução das narrativas modernas de memória no Egito}

Os anos de 1980 são marcados pelas preocupações feministas - como reação à cultura conservadora dominante desde a década anterior-, por isso desta geração nascem mulheres tradutoras (de diferentes correntes ideológicas que variam entre conservadoras e liberais) como 
Hala Awad, tradutora de Mario Vargas Llosa e Magda Haroun, tradudora de Juan Rulfo. O critério das experiências das personagens femininas destas obras traduzidas vai ser fundamental na seleção das obras para traduzir.

Na década de 1990 há um processo de construção de rumos para a tradução. Estes rumos parecem ser existencialistas, ou seja, preocupados com a existência na crise social e política que vive o atual regime do país como Gamal Shehid que traduziu Em Busca do Tempo Perdido de

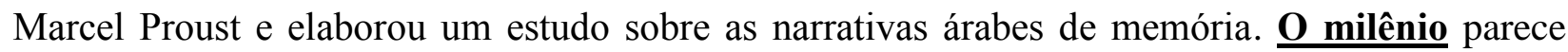
estar relacionado com a comunicação na internet para fugir do conservadorismo que domina o país.

\subsubsection{Agentes da tradução latino-americana no Egito}

Dentro deste marco histórico do movimento da tradução no Egito, pensamos que os critérios que orientavam a seleção de obras literárias para traduzi-las ao árabe eram a proximidade humana nos enredos narrativos e a abordagem de crises sociais e psíquicas interessantes para o leitor egípcio. Outro critério era que a obra tivesse uma inovação literária e estética relevante.

Neste momento, estão se desenvolvendo iniciativas para o estudo da tradução como ato de construção de uma Sociedade Democrática. Tais estudos da tradução vão ampliar a historiografia da tradução e estabelecer o sonhado Estado Democrático que estabelece visão para as políticas e as estratégias do Projeto da Tradução.

Atualmente no Egito se luta pelas mudanças democráticas e neste contexto terá vasta recepção a tradução das narrativas de memória da militância contra a ditadura como o romance Cinzas do norte. As literaturas de misturas culturais como a literatura afro-brasileira e a literatura dos descendentes de árabes poderão refletir processos de experiências de interculturalidade e de mestiçagem para buscar relações transculturais alternativas do Egito como no romance Relato de um certo oriente. 


\section{Conclusão}

$\mathrm{Na}$ crítica comparada e na tradução cultural se encontram vozes plurais, construtoras de memória cultural e de utopias que fazem resistência ao imperialismo neocolonial: a dos imigrantes e seus descendentes, a do escritor, a do crítico e a do tradutor, que tentam restaurar uma comunidade estilhaçada pelo imperialismo. Propusemos explorar alguns possíveis lócus de transculturação na abordagem das diferenças e das alteridades como manifestações das mobilidades culturais: a migração, a narrativa da memória e a tradução. Tentamos colocar em diálogo vários saberes e disciplinas como os estudos comparados da imigração, da memória, e da tradução para poder entender a fundo o processo semiótico do Relato de um certo oriente.

Tal como em Manaus se dá o Encontro das Águas, dá-se o encontro de mobilidades culturais como a dos diferentes imigrantes e seus descendentes. O Relato de um certo oriente apresenta uma aproximação não linear da realidade subjetiva desses imigrantes na cidade de Manaus após o fim do Ciclo da Borracha.

Essas relações de alteridades enredadas na realidade migratória podem ser traduzidas internamente pela imaginação da linguagem ficcional, que foge do discurso cartesiano do positivismo. O Relato de um certo oriente tem uma simbiose de dois mundos superpostos (do Líbano e de Manaus).

A mobilidade cultural de países árabes começou desde a vinda dos andaluzes na época dos Descobrimentos. As mobilidades migratórias posteriores dão lugar ao surgimento do fenômeno da "mascateação". As narrativas que o mascate levava de um lugar a outro resultou na integração entre centros urbanos e as áreas interioranas e rurais. O mesmo "mascate" foi integrado na vida social através da sua mobilidade. Os processos de colonização e a posterior crise do capitalismo no início do século XX resultaram no crescimento das mobilidades migratórias. A mudança abrupta resultava em tensões e marginalização ou em adaptação e integração. O deslocamento implicava novas misturas que se davam por meio de atos sociais (como o casamento entre Emilie, a católica e seu esposo muçulmano). Estas mobilidades migratórias envolviam diferentes graus de vinculação afetiva à terra de procedência e à de destino. 
A colonização engendrou a mobilidade cultural entre o Líbano e Manaus. Essas mudanças resultaram em memórias deslocadas e novos cruzamentos e misturas, como os caboclos. A situação econômica afetava essas mobilidades como foi o caso do Ciclo da Borracha e seu posterior fim. Essas mobilidades terminavam em células familiares inseridas na nova sociedade de imigrantes. Nota-se que as mobilidades migratórias são multidirecionais. No Relato há uma tendência ao movimento da periferia para o centro e ao contrário. Exemplo disso foi o retorno de Hatoum a Manaus depois de muitos anos que passou na Europa. A memória vira refúgio para a reinvenção desse espaço perdido, dessa "canção sequestrada". A reinvenção da memória, do que foi, era a única forma de recuperar imagens passadas, utópicas, de um espaço degradado pela modernização caótica da ditadura militar. Trata-se de uma forma de tomar consciência do que aconteceu, através de uma viagem para dentro. Rememorar vira uma forma de resistência às novas estruturas de dominação.

Para o mercado editorial de São Paulo, Milton Hatoum trazia dois mundos estigamatizados para o bem ou para o mal pelo olhar eurocêntrico. Ele se encontra frente a frente nos seus estudos de literatura francesa com a visão "orientalista" sobre o mundo árabe e sobre Amazonas. Como dizia Armando Mendes já em 1974, em seu livro A invenção da Amazônia, a imagem da região foi construída de fora para dentro, priorizando a paisagem, mas deixando invisíveis os seres humanos que vivem lá. $\mathrm{O}$ escritor tem que enfrentar categorias prontas para castrar as vozes periféricas como foi o caso do "regionalismo". Sua interação com outras culturas é movida pelo seu multiverso cultural (francês, árabe e brasileiro...). Essas mobilidades desestabilizam as certezas, por isso a indefinição do título do romance "um certo oriente".

$\mathrm{Na}$ narração do Relato, observa-se uma relação entre a construção da memória e a percepção sensorial, porque a memória é considerada um signo de vida ligado ao corpo (BACHELARD, 2008). Por isso, quem visita o centro de Manaus sente a mobilidade ligada à vida insinuada pela circularidade da arquitetura, das decorações e das construções antigas da cidade (casarões, alpendres, parques, fontes e colégios). Quem lê o Relato sente a mesma vitalidade circular na narração. As expressões semióticas dos espaços manauaras interagem com a vida dos sujeitos da narração. Muitas das descrições da casa no Relato dialogam com a bela Casa do Centro Cultural do Rio Negro. A vitalidade das variadas manifestações da linguagem artística (pintura, música, poesia, narrativas e filmes) nos leva a uma existência humana que 
resiste a morte. Edward Said (2009) apontava essa vitalidade na libertação serena de tudo o que prende o pensamento.

O Relato representa a vida de uma memória cultural partilhada entre os imigrantes árabes no Brasil. Nessa memória dialógica há lembranças mutáveis e outras invariantes que constituem as identidades . Observamos um modo dual de lembrar do descendente de imigrantes. Com um monólogo dialoganete, vê uma cena numa cultura e evoca outra. Essa memória cultural da imigração pode ser transmitida de geração em geração "intergeracional”, ou por aquisição pelos meios simbólicos que permeiam o sistema cultural no qual estamos inseridos, nesse caso é "transgeracional". O descendente é movido por um desejo de dar sentido às lembranças. A diferença da memória do passado, a construçaõ da memória no Relato parte do presente para marcar-se como memória da futura hibridação e da superação das diferenças entre cidade e campo.

A memória é lócus da identidade e da alteridade. A narrativa memorialística tende a ser costurada pelas incertezas dos entrelugares das memórias deslocadas. A mesma rememoração em si é um ato arriscado por essas incertezas das recordações, por isso só o discurso da ficção pode dar-se conta dele. O próprio escritor se move em dois entrelugares: além de ser filho de imigrantes, ele é deslocado de Manaus para São Paulo.

Outra manifestação das mobilidades culturais no Relato é a autoficção como forma de inserção dessas pequenas histórias, entre autobiografias de fatos reais tratados de modo imaginário, onde o Eu se move entre vários personagens fictícios. $\mathrm{O}$ escritor prepara um terreno de ambiguidade em que o Eu é ao mesmo tempo sujeito e objeto da narração (DOUBROVSKY, 1977, apud OUELLETTE- MICHALSKA, 2007). A ficcionalização da memória cultural passa por um processo de reinvenção consciente do inconsciente simbólico. A memória é recriada nos entrelugares de vozes fragmentárias e fantasmagóricas. Hatoum resgata a memória cultural do esquecimento, evocando imagens e experiências sensoriais de máterias-chaves da memória (como fotos, cadernos, objetos pessoais, cartas, cheiros). $\mathrm{Na}$ escrita, Hatoum filtra sua experiência para ter sentido e coerência interna num jugo de persistência em certas referências. A ausência produz polifonia de sentidos a partir de silêncios subjetivos. 
A fragmentação da narração consegue captar as histórias pequenas e caçar a dimensão íntima e experiências de alteridades de diversos narradores em trânsito. A escrita das memórias íntimas viram mais vivas nos entrelugares dos exilados. O Relato apresenta uma aproximação diferenciada das formações de identidades. A narativa de memória em Hatoum é polifônica, circular, refratária e mutliperspectival. Nela há vozes de estrangeiros, imigrantes e descendentes. Todas são localizadas em entrelugares, zonas de contato entre culturas. Na narrativa, são perceptíveis alguns processos transculturais que vivem os imigrantes e seus filhos. A narrativa polifônica multiperspectival rompe com a tradição literária exotizante destes mundos não europeus (o árabe e o amazonense).

Traduzir a memória numa escrita legível se torna forma de cura do exílio psicológico. Said aponta uma mobilidade na memória que vai como eterno retorno de resistência ao esquecimento de certos espaços. A memória é o local de tensões dos descendentes, que vivem uma vida dupla entre a família patriarcal e a sociedade liberal. O descendente vive experiências de familiarização do exótico e exotização do familiar. As aprendizagens de Hakim nos remetem a um processo psicológico indicado por Le Goff, como aquisição da memória num processo social assinalado por Florestan como aburguesamento. Hatoum e Hakim são guardiões de uma memória coletiva. Na construção memorialista, Hatoum reinventa vozes fragilizadas pelo deslocamento. No Relato, a família e a casa são espaços de interações interculturais e na insconsciente familiar são identificáveis ruínas de perdas emcionais. Esta forma de mobilidade cultural nos faz lembrar o conceito de "tarjama" em árabe, que define este tipo de escrita como uma tradução cultural das imagens relevantes na vida em narrativas.

A tradução literária gera novas alteridades externas. Começamos o presente trabalho com a complexidade que envolve o processo da tradução e propomos como objetivo expor alguns dos problemas encontrados durante a tradução para o árabe do Relato de um certo oriente. Dançamos com a polifonia narrativa e a mistura de vozes, tentando passos como desambiguação, identificação, codificação e a especificação semântica das palavras no seu contexto narrativo. Para dialogar com as alteridades ressaltadas por diferentes marcas culturais, usamos técnicas como a visualização, a explicitação discursiva, a translitração e o empréstimo. Tentamos produzir uma tradução transcultural que dialogasse com o leitor e mantivesse traços específicos do texto 
fonte. Tendo em vista que o campo da tradução literária do português ao árabe ainda é incipiente, continuamos tentando desenvolver uma tradução intercultural que dialoga com os outros dentro do texto e os outros fora do texto no campo literário árabe pós-colonial, que está tendo um crescente interesse editorial na publicação da literatura brasileira.

Nesse contexto, a integração se dá por meio da tradução cultural como imaginação presente nas preocupações de todas as mobilidades que propõe construir novas formas de emancipação social. A tradução está inscrita no contexto das mobilidades transculturais como:

Um trabalho argumentativo de imaginação epistemológica e de imaginação democrática presente nas reflexões e preocupações de todas aquelas perspectivas, movimentos e práticas que propõe o objetivo de construir novas e plurais formas de emancipação social (SANTOS, 2005:168).

Estas mobilidades envolvem deslocamentos de significados, vínculos e memórias vagas em tempos e espaços incertos. De acordo com Williams \& Chesterman (2002), os estudos da tradução pesquisam três processos: hermenêutica do tradutor, ou seja, a semântica das unidades do texto traduzido, produzida a partir de leituras, interpretação e compreensão; a estilística do discurso traduzido, produzido por meio da recriação e da reexpressão; e sociologia do da tradução e sua recepção.

A literatura brasileira e a árabe, apesar de sua riqueza e das muitas semelhanças entre as duas culturas, ainda carecem de contato e conhecimento mútuo. Um meio de sanar esse hiato são as traduções e os estudos transculturais. Pensando na proximidade entre tais mundos linguísticos, decidimos estudar língua portuguesa e literatura brasileira. Atravessamos os obstáculos linguísticos para poder traduzir para o árabe Relato de um certo oriente, de Milton Hatoum. 


\section{Referências bibliográficas}

ABDALA Jr., Benjamin. Fronteiras múltiplas, identidades plurais - um ensaio sobre mestiçagem e hibridismo cultural. São Paulo: Editora SENAC São Paulo, 2002.

ABDALA Jr., Benjamin, (org.). Margens da cultura: mestiçagem, hibridismo e outras misturas. São Paulo: Boitempo, 2004.

ABDALA Jr., Benjamin. Literatura, história e política. São Paulo: Ateliê Editorial, 2007.

ABDALA Jr., Benjamin. "Notas críticas. Administração da diferença, preservação da hegemonia”. In: MARGATO, Izabel; GOMES, Renato Cordeiro (Org.). Literatura e revolução. Belo Horizonte: Editora UFMG, 2012, v., p. 29-41.

ABRÃO, Gilberto. Mohamed, o latoeiro. São Paulo: Primavera Editorial, 2009.

AIXELLÁ, Javier Franco. La traducción condicionada de los nombres propios inglés-español. Salamanca: Almar, 2000.

ALMEIDA, José Maurício Gomes de. A tradição regionalista no romance brasileiro (18571945). Rio de Janeiro: Achiamé, 1981.

AMADO, Jorge. A descoberta das Américas pelos turcos. Rio de Janeiro: Record, 1994.

ANDRADE, Carlos Drummond de. Poesia Completa. Rio de Janeiro: Nova Aguilar. 2007

ANTONACCIO, Gaitano. Colônia árabe nas Amazonas. Manaus: [s.n.], 1996.

ASSMANN, Aleida. Espaços da recordação: formas e transformações da memória cultural. Campinas: UNICAMP, 2011.

AUBERT, Francis Henrik. "Indagações acerca dos marcadores culturais na tradução". In Revista de Estudos Orientais. No. 5. São Paulo, 2006. 
AUERBACH, Erich. Mimesis: a representação da realidade na literatura ocidental. Tradução de George Bernard Sperber. São Paulo. Editora Perspectiva, 1976.

AVILA, Myriam Correa de Araujo. "A posição do discurso latinoamericano". In o Eixo e a rdoa. Belo Horizonte. v.18, n.2, 2009.

BACHELARD, Gaston. Poética do Espaço. São Paulo: Martins Fontes, 2008.

BAKER, Mona. Encyclopedia of Translation Studies, London: Routledge, 1998.

BAKHTIN, Mikhailovich, Mikhail. Problems of Dostoevsky's Poetics, Editado e traduzido por Caryl Emerson. Minneapolis: University of Minnesota Press, 1984.

BASSNETT, Susan. Translation studies. London: Routledge, 1980.

BASTIN, Georges. ¿Traducir o Adaptar? Caracas: Universidad Central de Venezuela, FHE/CDCH, 1998.

BOLLE, Willi. “A travessia pioneira da Amazônia”. In Amazônia: região universal e teatro do mundo, Org. Willi Bolle, Edna Castro, Marcel Vejmelka. São Paulo: Globo, 2010, pp. 19-56.

BORGES, Kárita Aparecida de Paula. "Manaus: a aldeia universal de Milton Hatoum”. In: Anais do SILEL. Volume 1. Uberlândia: EDUFU, 2009.

BERND, Zilá. (Org.) Dicionário das mobilidades culturais. Porto Alegre: Literalis, 2010.

BERND, Zilá. (Org.) Dicionário de figuras e mitos literários da América. Porto Alegre: Tomo Editorial/ Editora da UFRGS, 2007.

BHABHA, Homi K. O local da cultura. Belo Horizonte: Editora UFMG, 2001.

BORGES, Kárita Aparecida de Paula. "Manaus: A aldeia universal de Milton Hatoum”. In: Anais do SILEL. Volume 1. Uberlândia: EDUFU, 2009.

BOSI, Alfredo. História concisa da literatura brasileira. 2ª ed. São Paulo: Cultrix, 1976. 
BOSI, Alfredo. Dialética da colonização. São Paulo: Companhia das Letras, 1992.

BOSI, Ecléa. Memória e Sociedade: lembrança de velho. São Paulo: Companhia das Letras, 2004.

BOURDIEU, Pierre. O poder simbólico. Lisboa/Rio de Janeiro: Difel/Bertrand do Brasil, 1989.

BOURDIEU, Pierre. "Les conditions sociales de la circulation internationale des idées". In Romanistische Zeitschrift fur Literaturgeschichte/Cahiers d'Histoire des Littératures Romanes, Volume 14, Number 1/2, pp. 1-10, 1990.

BOURDIEU, Pierre. Las reglas del arte. Barcelona: Anagrama, 1995.

BUNGE, Mario. La investigación científica. Su estrategia y su filosofia. México: Siglo XXI Editores, 2000.

CAMPOS, Haroldo de. "Da tradução como criação e como crítica". In Tempo Brasileiro Rio de Janeiro, 1963; republicado in: Metalinguagem e outras metas. São Paulo: Perspectiva, 1992. pp. $31-48$.

CAMPOS, Haroldo de. Deus e o diabo no Fausto de Goethe. São Paulo: Perspectiva, 1981.

CANDIDO, Antonio. A educação pela noite e outros ensaios. São Paulo: Ática, 1985.

CARBONELL, Ovidio Cortés. "Orientalism in Translation: Familiarizing and defamiliarizing strategies". In Translators' strategies and creativity - Selected papers from the $9^{\text {th }}$ international conference on translation and interpreting, 63-70. Prague, 1995.

CARBONELL, Ovidio Cortés. “Del 'Conocimiento del mundo' al discurso ideológico: el papel del traductor como mediador entre culturas". In Esther Morillas y Juan Pablo Arias (eds.), El papel del traductor, Edit Biblioteca de traducción, 1997.

CARREIRA, Shirley de Souza Gomes. "Amrik, de Ana Miranda: a imigração libanesa revisitada". Vertentes (UFSJ), v. 32, p. 109-119, 2008. 
CARREIRA, Shirley de Souza Gomes. "Imigrantes: a representação da identidade cultural em Relato de um certo Oriente e Amrik". In: MIRANDA, Adelaide et al. Protocolos críticos. São Paulo: Iluminuras: Itaú Cultural, 2009a.

CARREIRA, Shirley de Souza Gomes. "Diferença E Alteridade Em Cinzas Do Norte, De Milton Hatoum". Vertentes (UFSJ), v. 34, p. 20-28, 2009 b.

CRISTO, Maria da Luz Pinheiro (Org.). Arquitetura da Memória: ensaios sobre os romances Relato de um Certo Oriente e Dois Irmãos, de Milton Hatoum. Manaus: Editora da Universidade do Amazonas, 2005.

CURY, Maria Zilda Ferreira. "Fronteiras da memória na ficção de Milton Hatoum". Letras (Santa Maria), Santa Maria, v. 26, p. 11-19, 2003.

CURY, Maria Zilda Ferreira. "Memórias da imigração". In: SELIGMAN-SILVA, Márcio. (Org.). Palavra e imagem: memória e escritura. Palavra e imagem: memória e escritura. 1ed.Chapecó: Argos, 2006, v. 1, p. 303-326.

CURY, Maria Zilda Ferreira. "Entre o rio e o cedro: imigração e memória". In: Maria da Luz Pinheiro de CRISTO. (Org.). Arquitetura da memória: ensaios sobre os romances Relato de um certo oriente, Dois irmãos e Cinzas do Norte de Milton Hatoum. 1 ed. Manaus: Editora da Universidade Federal do Amazonas/UNINORTE, 2007, v. 1, p. 82-97.

CURY, Maria Zilda Ferreira. “Topografias da ficção de Milton Hatoum”. In: CURY, Maria Zilda Ferreira; RAVETTI, Graciela; ÁVILA, Myriam. (Org.). Topografias da cultura: representação, espaço e memória. $1^{\mathrm{a}}$ ed. Belo Horizonte: Editora UFMG, 2009, v. 1, p. 41-62.

DE ANDRADE, Sara Simões. Desorientes no Brasil: visto de permanência dos libaneses na ficção brasileira. Dissertação de Mestrado. Departamento de Teoria Literária. Universidade de Brasília, 2007.

EMMA, Rodríguez et al. La lectura, Cali (Colombia): Universidad del Valle, 2003. 
ENANI, Mohamed, Teoria Moderna da tradução- Introdução nos estudos da tradução, O Cairo: Longman, $2^{\mathrm{a}}$ ed., 2005.

/moḥamed 'ananī: națaryetu al targamati al ḥaditá-madḩalu 'ila mabḥat dirasat al targamá, Al Qahirá, al šarkatu al mișrya al 'alamya lilnašr-longman- alțab 'atu al taniya, 2005/
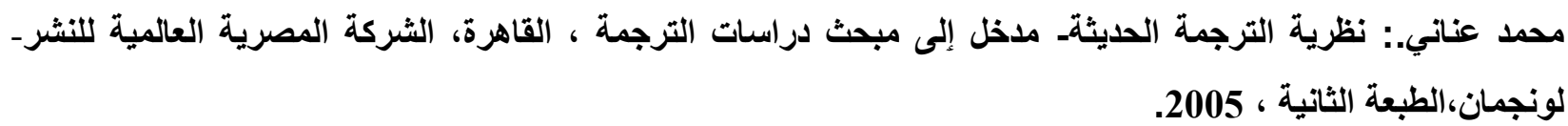

FANTINI, Marli. “Águas turvas, identidades quebradas: hibridismo, heterogeneidade, mestiçagem \& outras misturas”. In: Benjamin Abdala Junior. (Org.). Margens da cultura. São Paulo: Boitempo, 2004, pp. 159-180.

FERNANDES, Florestan. A revolução burguesa no Brasil. Ensaio de interpretação sociológica. Rio de Janeiro: Zahar Editores, 1975.

FIGUEIREDO, Eurídice. (Org). Conceitos de literatura e cultura. Niterói: EdUFF, 2010.

FRANCISCO, Denis Leandro. A ficção em ruínas: Relato de um certo Oriente, de Milton Hatoum. Dissertação de Mestrado. Programa de Pós-graduação em Letras: Estudos Literários, da Faculdade de Letras da Universidade Federal de Minas Gerais, Belo Horizonte, MG. 2007.

FREIRE, José Alonso Torres. Entre construções e ruínas: uma leitura do espaço amazônico em romances de Dalcídio Jurandir e Milton Hatoum. Tese de Doutorado. São Paulo: FFLCH-USP, 2006.

FREITAS, Júlia Maria Amorim. “A casa e a língua: redes de textualidade e territorialidade em Relato de um certo oriente de Miltom Hatoum". In: V Congresso de Ciências Humanas, Letras e Artes. Ouro Preto. V Congresso de Ciências Humanas, Letras e Artes - Encontro Conifes. Mariana: UFOP, V. único, 2001.

GADAMER, Hans-Georg. Verdad y Método. Fundamentos de una hermenéutica filosófica. Tr.: Ana Agud Aparicio y Rafael de Agapito. Vol. I. Salamanca: Sígueme, 1977.

GATTAZ, André. Do Líbano ao Brasil: história oral dos imigrantes. São Paulo: Gandalf, 2005. 
GOMES, Clarissa Rodrigues Pinheiro; BARBOSA, Sidney. "O coro de vozes em Relato de um certo oriente de Milton Hatoum”. Estudos Linguísticos. São Paulo, v. XXXV, p. 482-491, 2005. http://www.gel.org.br/estudoslinguisticos/edicoesanteriores/4publica-estudos2006/sistema06/763.pdf. Acesso em 25/07/2012.

GONÇALVES FILHO, Antonio. O evangelho de Hatoum. São Paulo: Valor, 28-30. Jun. 2000.

GONÇALVES, Érica Renata. "Lavoura Arcaica: análise de personagens na literatura e no cinema". Trabalho apresentado no Grupo de História da Mídia Audiovisual no VI Congresso Nacional de História da Mídia. 2008.

GOUVANIC, Jean-Marc. "A Bourdieusian Theory of Translation, or the Coincidence of Practical Instances (Field, Habitus, Capital and Illusion)". Translator Studies in Intercultural Communications, v. 11, No 2,147-192. Manchester, UK, 2005.

GRANJA, Sergio. "O estrangeiro de si mesmo em Lavoura Arcaica”. Rio de Janeiro: Seção de Crítica do Portal da Fundação Lauro Campos, 2007. Acesso: 28/07/2012. http://www.socialismo.org.br/portal/critica/666-o-estrangeiro-de-si-mesmo-em-lavoura-arcaica

HALBWACHS, Maurice. A memória coletiva. [Tradução de Laurent León Schaffter do original francês de 1949]. São Paulo: Vértice, 1990.

HAMID, Sonia Cristina. Entre a Guerra e o Gênero: Memória e Identidade de Mulheres Palestinas em Brasília. Dissertação de mestrado. Brasília: Universidade de Brasília, 2007.

HAMON, Philippe. Texte et idéologie. Paris: Quadrige/PUF, 1997.

HATIM, Basil; MASON, Ian. "Discourse and the translator". Language in Social Life Series. Longman, 1990.

HATOUM, Milton. Relato de um Certo Oriente. São Paulo: Cia. das Letras, 1990.

HATOUM, Milton. "Passagem para um certo Oriente". Remate de Males. Campinas, n. 13, p. 165-168, 1993.

HATOUM, Milton. Dois Irmãos. São Paulo: Cia. das Letras, 2000. 
HATOUM, Milton. Collatio, ano IV, n. 6, 2001. Disponível em: http://www.hottopos.com/collat6/milton1.htm.. Acesso em: 10 maios 2010. Entrevista concedida a Aida Ramezá Hanania.

HATOUM, Milton. Cinzas do Norte. São Paulo: Cia. das Letras, 2005a.

HATOUM, Milton. "Cinzas que queimam". Entrevista concedida à Julián Fuks. Folha de S. Paulo, Folha ilustrada, 13 de agosto de 2005b.

HATOUM, Milton. "Laços de Parentesco: Ficção e Antropologia". RAÍZES DA AMAZÔNIA. Manaus: INPA Ano I - V. 1, $\mathrm{n}^{\circ} 1,2005 \mathrm{c}$.

HATOUM, Milton. "Treze perguntas para Milton Hatoum”. Magma / Departamento de Teoria Literária e Literatura Comparada. FFLCH/USP. São Paulo: Editora da USP, 2003.

HATOUM, Milton. Órfãos do Eldorado. São Paulo: Cia. das Letras, 2008.

HATOUM, Milton. Cidade ilhada. São Paulo: Cia. das Letras, 2009.

HATOUM, Milton. "Milton Hatoum: Não há tantos tradutores de literaturas de língua portuguesa", maio 2010, São Paulo: Revista Eletrônica Crioula da USP, número 7, página visitada em 8 de abril 2012. Entrevista concedida a Maged El Gebaly.

HEIDEGGER, Martin. Acheminement vers la parole. Tr.: E. Fédier. Paris: Gallimard, 1983.

HERMANS, Theo. "The translator voice in translated narrative". In Critical Readings in Translation Studies. London \& New York: Routledge, 2010.

HOLANDA, Sérgio Buarque de. Caminhos e fronteiras. Rio de Janeiro: Editora José Olimpio, 1957.

HURTADO ALBIR, Amparo. Traducción y Traductología Introducción a la traductología. Madrid: Ediciones Cátedra, 2001.

HUYSSEN, Andreas. Memórias do modernismo; tradução de Patrícia Farias. Rio de Janeiro: Editora UFRJ, 1996. 
IEGELSKI, Francine. Tempo e memória, literatura e história. Alguns apontamentos sobre LAVOURA ARCAICA, de Raduan Nassar e RELATO DE UM CERTO ORIENTE, de Milton Hatoum. Dissertação de mestrado. São Paulo: FFLCH-USP, 2006.

JUNG, Carl Gustav. "A individuação". In: O Eu e o inconsciente. Petrópolis: Vozes, 1984.p.49115.

KANZEPOLSKY, Adriana. "Escribir la memoria". Revista Nueve Perros. Argentina, v. 4, p. 2427, 2002.

KANZEPOLSKY, Adriana. "Rasgar el presente. Memoria y fabulación en Relato de un cierto Oriente". Revista de Estudos Orientais da USP. nº 6, p. 95-107, 2008.

KARAM, John Tofik. Um outro arabeso. Etnicidade sírio-libanesa no Brasil neoliberal. São Paulo: Martins Fonts, 2007.

KHATLAB, Roberto. Libano: Guia Turístico e Cultural. Rio de Janeiro: Ed. Jamal, 2000.

KNOWLTON, Clark Shumway. Sírios e libaneses: mobilidade social e espacial. São Paulo: ANHAMBI, 1955.

KRISTEVA, Julia. Séméiôtiké: recherches pour une sémanalyse. Paris: Edition du Seuil, 1969.

KRUGER, Marcos Frederico. "O Mito de origem em Dois Irmãos". In: Maria da Luz Pinheiro de Cristo. (Org.). Arquitetura da Memória. Manaus: EDUA - Ed. da Universidade Federal do Amazonas, v. Único, pp. 180-191, 2002.

LEAL, Bruno Avelino. Nas trilhas de Milton Hatoum, Um breve estudo de uma trajetória intelectual. Dissertação de mestrado. Manaus: Universidade Federal do Amazonas, 2010.

LEÃO, Ademar. Dois Irmãos, um romance às margens do Negro. Dissertação de mestrado. Santa Maria (RS, Brasil): Universidade Federal de Santa Maria. 2005.

LEHRER, Jonah. Proust foi um neurocientista. Tradução Fátima Santos. Rio de Janeiro: Best Seller, 2010. 
LEVINAS, Emmanuel. Totalidade e infinito. (1961). Tr.: José Pinto Ribeiro, Lisboa- Portugal, Edições 70, 1988.

LOPES, Denilson. "Del Entre-Lugar a lo Transcultural". In: Marina Moguillansky; Andrea Molfetta; Miguel Angel Santagada. (Org.). Del Entre-Lugar a lo Transcultural. 1ed.Buenos Aires: Teseo, 2010, p. 19-42.

MABROUK, Mohamad Ibrahim. Como a tradução formula seus criadores. Cairo: Edit. Al Alsun, 2007.

/moḥamed ibrahim mabruk: al targamatu wa kaifa tassioghu mobdi'aihá. miglatu al alsun. gaami 'at 'ain šams, al qahirá, 2007/

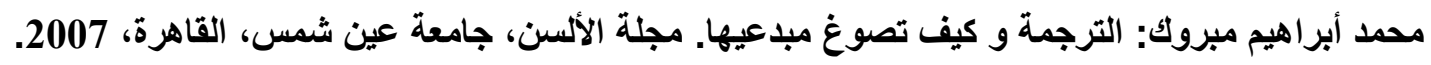

MASSEBEUF, FERNANDA. "Processos de Aculturação e Alteridade em Miltom Hatoum". São Paulo: Jornal $O$ Panorama $d a \quad$ Palavra, $\quad \mathrm{N}^{\circ} \quad$ 59, 2006. http://www.panoramadapalavra.com.br/index59.asp. Acesso: 04/07/2012

MAQUÊA, Vera Lucia da Rocha. Memórias inventadas: um estudo comparado de Relato de um certo oriente de Milton Hatoum e Um rio chamado tempo, uma casa chamada terra, de Mia Couto. Tese de Doutorado. São Paulo: FFLCH-USP, 2007.

MENDES, Armando Dias. A invenção da Amazônia. 2.ed. Manaus:Editora da Universidade do Amazonas, 1997.

MEYLAERTS, Reine. "Revisiting the Classics, Sociology and Interculturality, Creating the Conditions for Inter-national Dialogue across Intellectual Fields". The Translator, Volume11, Number 2, 277-283, Manchester: St Jerome Publishing, 2005.

MIGLIARI, Giselle Cristina Gonçalves. "A tradução literária com base no Perspectivismo". Cadernos de Literatura em Tradução, v. 11, p. 1-17, 2010.

MIRANDA, Ana. Amrik. São Paulo: Cia das Letras, 1997. 
MOREIRA, Maria Luiza Alameda Moreira. Milton Hatoum e o exilio como metáfora para a condição intelectual. Dissertação de Mestrado. Departamento de Pós Graduação em Estudos Literários da Universidade Federal de Juiz de Fora, Juiz de Fora, MG. 2007.

MOREIRA, Susana Marques. "Mil e uma noites até Manaus. Os livros também têm biografia", Jornal o Público, Lisboa. 28/07/2012. http://www.publico.pt/Cultura/mil-e-uma-noites-atemanaus-1556710?all=1. Acesso: 28/07/2012.

MORIN, Edgar. Os sete saberes necessários à educação do futuro. Tr.: Catarina Eleonora F. da Silva e Jeanne Sawaya. São Paulo: Cortez; Brasília: DF: UNESCO, 2011.

MÜLLER, Fernanda. “A úmida claustrofobia da Manaus de Hatoum”. In: Anais do Simpósio Internacional Linguagens e Culturas: Homenagem aos 40 anos dos Programas de Pós-Gradução em Linguística, Literatura e Inglês da UFSC. Florianópolis: UFSC, 2011. (pp. 835-853).

NABUCO, Joaquim. Minha formação. Rio de Janeiro: Topbooks, 1999.

NASSAR, Raduan. Lavoura Arcaica. São Paulo: Companhia das Letras, 1989.

NIDA, Eugene Albert; TABER Charles R. The Theory and Practice of Translation, Leiden: E. J. Brill, 1969.

OLIVEIRA, Paulo César Silva. "Zona de fronteira: ressonâncias críticas na obra de Milton Hatoum". CHAVES, Eneida Maria (org) Vertentes (São João Del-Rei), v. il:, p. 63-73, 2008.

OUELLETTE- MICHALSKA, Mafeleine. Autofiction e devoilemente de soi. Montreal: XYZ éditeur, 2007.

PALUMBO, Giuseppe. Key terms in translation studies. Chennai: Editorial Continuum, 2009.

PAZ, Octavio. Traducción: Literatura y literalidad. Barcelona: Tuquets Editores, 1971.

PERDIGÃO, Noemi Henriqueta Brandão de. "A Nova Amazônia dos Romances Relato de Um Certo Oriente e Dois Irmãos". In: Benito Martinez Rodriguez. (Org.). Anais do XII Congresso Internacional de Literatura Comparada (ABRALIC), Centro, Centros, Ética e Estética, 2011. 
PEREIRA, Maria Antonieta. "Entre-lugar e ex-tradição - as picadas do discurso latinoamericano". In: XVII Encontro Nacional da ANPOLL, 2002, Gramado - RS, 2002.

PETERS, Roberta. A recriação das tradições árabes através do ritual de casamento entre famílias de imigrantes palestinos no Rio Grande do Sul. Dissertação de mestrado. Porto Alegre: Universidade Federal de Rio Grande do Sul, 2006.

POLLAK, Michael. "Memória e identidade social”. In: Estudos Históricos. Rio de Janeiro, vol. $5, n^{\circ} 10,1992$.

PRADO BIEZMA, Javier del. Cómo se analiza una novela, Madrid: Editorial Alhambra, 1983.

PYM, Anthony. Method in Translation History. London/Manchester: St Jerome Eds, 1998.

RAMA, Angel. Transculturación narrativa em América Latina. México DF: Siglo Veintiuno, 1982.

REZENDE, Renato Cabral. Expedientes metadiscursivos na articulação e categorização de práticas comunicativas em Relato de um certo oriente, de Milton Hatoum. Campinhas: Universidade Estadual de Campinas, UNICAMP, 2010.

RIBEIRO, Darcy. O povo brasileiro: a formação e o sentido do Brasil. São Paulo: Companhia das Letras, 1999.

RICOEUR, Paul. A memória, a história, o esquecimento. Tradução: Alain François. Campinas, SP: Editora da UNICAMP, 2007.

RICOEUR, Paul. Sobre a tradução. Tradução e prefácio Patrícia Lavelle. Belo Horizonte: Editora UFMG, 2011.

RUIZ MONEVA, María Ángeles. "Diferencias en contexto, diferencias en interpretación". In FÉLIX FERNÁNDEZ, Leandro; ORTEGA ARJONILLA, Emilio Actas de las II Jornadas Internacionales de traducción e interpretación de la Universidad de Málaga. Universidad de Zaragoza, 1998. 
SAID, Edward. Orientalism. London \& New York: Vintage Books, 1978 \& Penguin Editions, 1995.

SAID, Edward. Fora do lugar: Memórias. Trad. José Geraldo Couto. São Paulo: Companhia das Letras, 2004.

SAID, Edward. Representações do intelectual: as Conferências Reith de 1993. Tr.: Milton Hatoum. São Paulo: Companhia das Letras, 2005.

SAID, Edward. Humanismo e crítica democrática. Trad. Rosaura Eickenberg. São Paulo: Companhia das Letras, 2007.

SAID, Edward. Estilo tardio. Trad. Samuel Titan Junior. São Paulo: Companhia das Letras, 2009.

SAFATLE, Vladimir Pinheiro. "Sobre o ato de rememorar como forma de cura: consideracões sobre o recurso freudiano à rememoração". In: Galle, Helmut; Schmidt, Rainer. (Org.). A memória e as ciências humanas: um conceito transdisciplinar em pesquisas atuais na Alemanha e no Brasil. São Paulo: Humanitas, 2011, p. 39-619.

SAMPAIO, Aíla Maria Leite. "Personagens em trânsito, espaços subjetivos e intertextos em A cidade ilhada, de Milton Hatoum". Revista Letras (Curitiba), v. 5, p. 1-5, 2010.

SANTIAGO, Silviano. "O entre-lugar do discurso latinoamericano". Uma literatura nos trópicos: ensaios sobre depenência cultural. São Paulo: Perspectiva/ Secretaria da Cultura, Ciência e Tecnologia, 1978.

SANTOS, Boaventura de Sousa. El milenio huérfano. Madrid: Akal, 2005.

SANTOS, Milton. A natureza do espaço: técnica e tempo, razão e emoção. São Paulo: Edusp, 2006.

SANTOS, Myrian Sepúlveda dos. "Sobre a autonomia das novas identidades coletivas: alguns problemas teóricos”. Revista Brasileira de Ciências Sociais. São Paulo, v. 13, n. 38, Oct. 1998. 
SCHLEIERMACHER, Friedrich. "On the Different Methods of Translating". In VENUTI, Lawrence (ed.), The Translation Studies Reader. New York: Routledge, 2004.

SELESKOVITCH, Danica; LEDERER, Marianne. Interpreter pour traduire, Collection Traductologie, 4, Paris : Publication de la Sorbonne/Didier Ėrudition, 1993.

SHAHID, Gamal. A memória no romance árabe contemporâneo. Beirute: Instituição Árabe para Estudos e Publicação, 2011.

/ jamal šahid. azaakiratu fi riuaiati al'a rabia al mu'asira. almu'assasa al 'arabia lil dirassaat wa anašr, Beirut, 2011/

جمال شحيد. الذاكرة في الرواية العربية المعاصرة. المؤسسة العربية للارسات والنثر، بيروت،2011

SILVA, Ana Cláudia de Oliveira da Silva. "Uma Luz (Nur) na escuridão: Salim Miguel e o papel do narrador". REEL. Revista Eletrônica de Estudos Literários, v. nº7, p. 1, 2010.

SILVA, Elias dos Santos; PEREIRA, Juvelina Zompero. "O conflito de gerações em Lavoura Arcaica: a eclosão de uma nova ordem". Rabiscos de Primeira (UFMS), Campo Grande, v. 5, n.5, p. 83-87, 2005.

SILVA, Joanna. Relações de Gênero no romance de Milton Hatoum. Dissertação de mestrado. São João Del-Rei (Minas Gerais): Universidade Federal São João Del- Rei, 2011.

SILVA, Nádia Regina Barbosa Da. "Memória e Identidade: uma leitura do romance Dois Irmãos de Milton Hatoum". In: Anais do XI Congresso Internacional da ABRALIC, TESSITURAS, INTERAÇÕES, CONVERGÊNCIAS. São Paulo, v. 19. p. 1-12, 2008.

SIMEONI, Daniel. "The Pivotal Status of the Translator's Habitus". Target International Journal of Translation Studies, P.10:1 1-39. Amsterdam: John Benjamin B.V. Publisher, 1998.

SOROKIN, Pitirim. Social and cultural mobility. London: Collier-Macmilliam Limited, 1964.

SOUZA, Maria Luiza Germano. "O sertão revisitado. O regionalismo literário amazônico em Elson Farias e Milton Hatoum”. Dissertação de mestrado. Manaus: Universidade Federal do Amazonas, 2010. 
STEINER, George. After Babel. Oxford: Oxford University Press, 1975.

SURDI, Mary Stela. "Conversas com vozes sem nomes: Análise do livro Relato de um certo Oriente, de Milton Hatoum". Revista Voz das Letras, v. 1, p. 9, 2008. http://www.nead.uncnet.br/2009/revistas/letras/9/94.pdf Acesso: 10/06/2010.

TOBÓN DE CASTRO, Lucía. La linguística del lenguaje: Estudios en torno a los procesos de significar y comunica. Bogotá: Paidós, 1991.

TOLEDO, Marleine Paula e Freire. Itinerário para um certo relato. São Paulo: Ateliê Editorial, 2006.

TÔNUS, José Leonardo. "O efeito exótico em Milton Hatoum”. Estudos de literatura brasileira contemporânea, n. ${ }^{\circ}$ 26. Brasília, julho-dezembro de 2005, pp. 137-148.

VAN DIJK, Teun. Ideología, Barcelona: Edit. Gedisa, 1999.

VASCONCELOS, Lucimara Regina de Souza. A função da transposição dos mitos em Órfãos Do Eldorado de Milton Hatoum. Dissertação de mestrado. Curitiba: Universidade Centro Universitário Campos de Andrade - UNIANDRADE, 2010.

VENUTI, Lawrence (editor). Rethinking translation - discourse, subjectivity, \& Ideology. London and New York: Edit.Routledge, 1992.

VENUTI, Lawrence. The translator' invisibility. New York: Edit.Routledge, 1995.

VENUTI, Lawrence (Editor). The translation studies reader. New York: Edit. Routledge, 2000.

VENUTI, Lawrence (ed.). The Translation Studies Reader. New York: Routledge, 2004.

VICO, Giambattista. A ciência nova. Tradução de Marco Lucchesi. Rio de Janeiro: Record, 1999. VIEIRA, Miguel Heitor Braga. "O percurso inicial da revolta em Lavoura Arcaica, de Raduan Nassar". Terra Roxa e Outras Terras. V. 11, pp. 103-112, 2007.

VIEIRA, Noemi Campos Freitas. "Narrativas da identidade: memória e esquecimento em textos de Milton Hatoum". Letras \& Letras, v. 24, p. 131-14. 2008. 
WARD, Colleen, \& RANA-DEUBA, Arzu. “Acculturation and adaptation revisited”. Journal of Cross-Cultural Psychology, Vol. 30, No. 4, July, pp. 422-442, 1999.

WILLIAMS, J.enny; ANDREW, Chesterman. The Map. A beginner's guide to doing research in translation studies. Manchester: St Jerome Publishing, 2002.

ZAIDAN, As'ad. Letras e História: mil palavras árabes de origem portuguesa. São Paulo: Escrituras Editoras: EDUSP, 2010. 


\section{Anexos \\ Anexo 1: Entrevista ${ }^{15}$ com Milton Hatoum: "Não há tantos tradutores de literaturas de língua portuguesa"}

Nessa entrevista com Milton Hatoum, abordamos temas relacionados à literatura e ao exercício de tradução, além de colher as impressões do autor sobre outros temas como as questões políticas relacionadas ao Oriente Médio e a relação do escritor com o Líbano.

MAGED EL GEBALY: O título de seu romance Relato de um certo oriente é uma crítica ao orientalismo ou ao discurso orientalista estudado por Edward Said?

MILTON HATOUM: O Orientalismo, livro de Edward Said, foi uma das leituras mais importantes sobre essa questão da construção imaginária do discurso sobre o outro oriental, sobretudo sobre o mundo islâmico. O Orientalismo é um dos ensaios seminais sobre as relações entre o Oriente e o Ocidente, sendo que o Oriente, como Said mostrou, é uma construção, é uma invenção do Ocidente. É um tipo de representação que o discurso orientalista teceu ao longo da história, sobretudo a partir do século XVIII. Pode ser que haja, inconscientemente, uma influência do Edward Said no título. A verdade é que foi difícil encontrar este título. Para mim foi um achado. Eu já havia praticamente terminado o romance e tinha outros títulos em mente, como "Retratos da memória". Eu lembro que esse era um dos títulos possíveis, mas gostei desse título Relato de um certo oriente, porque nele há várias perguntas. De que Oriente nós estamos falando? De um determinado Oriente? Mas qual deles? É isso que o livro insinua. É o mistério em torno desse Oriente que está um pouco nebuloso, e ainda não se sabe qual é o Oriente do romance.

\footnotetext{
${ }^{15}$ A entrevista foi realizada no escritório de Milton Hatoum em Pinheiros (São Paulo), no dia 23 de fevereiro 2010, mais ou menos das $14 \mathrm{~h}$ até $16 \mathrm{~h} 30 \mathrm{~min}$. Esta entrevista foi publicada na página web da Revista Crioula (USP), No 07. maio, 2010.
} 
MAGED EL GEBALY: Por que a dupla indefinição do título (não é de certo, mas de um certo Oriente)?

MILTON HATOUM: Isso dá mais ambiguidade ao título. O leitor não sabe exatamente do que se trata esse Oriente. A literatura trabalha com a ambiguidade, isso a enriquece. Tudo o que é muito determinado ou explicado prejudica o romance. $\mathrm{O}$ romance questiona, indaga, insinua, suscita perguntas; mas ele não pode explicar. O romance explicativo é chatíssimo.

MAGED EL GEBALY: Qual a inspiração para a morte da personagem Soraya Delia, neta de Emilie, num acidente no Relato?

MILTON HATOUM: Isso aconteceu em minha família. Quando eu era criança, brincava muito com uma prima que era surda-muda, como está no livro. E, um dia, ela saiu correndo para a rua e foi atropelada por um ônibus. Morreu instantaneamente. Foi uma das cenas mais chocantes de minha infância, uma cena que nunca esqueci. Eu me lembro do desespero e da tristeza da mãe dela (minha tia) e dos parentes chorando quando souberam que ela fora atropelada. Eu era muito pequeno, devia ter uns seis anos, mas esse fato ficou muito marcado em minha memória. É um episódio autobiográfico, no sentido de que aconteceu algo parecido à cena do romance. A memória inventa suas versões a partir de um fato do passado.

MAGED EL GEBALY: Como foi a experiência de traduzir Representações de um intelectual, de Said? Com que problemas se deparou?

MILTON HATOUM: Indiquei para o meu editor da Companhia da Letras a publicação de Orientalismo. A editora comprou os direitos do livro e o publicou, em 1992, data da primeira edição, cuja tradução tinha algumas falhas. Há uns dois ou três anos, essa tradução foi refeita e a obra saiu em edição de bolso. A editora publicou outros livros de Edward Said: Cultura e imperialismo, Fora de lugar, Paralelos e paradoxos (com Daniel Barenboim).

Eu me propus a traduzir Representações do intelectual. Foi uma tradução que me deu trabalho, porque esse livro, na verdade, são conferências de Said para um programa da BBC de enorme 
prestígio, as "Reith Lectures". Essas conferências foram escritas para serem transmitidas. O autor fez algumas alterações para a versão escrita. Então, a dificuldade é que as frases de Said são muito longas e um pouco sinuosas, e isso deu um pouco de trabalho, mas não é tão difícil quanto traduzir ficção.

Na ficção, há uma liberdade de estilo, de vocabulário, às vezes uma sintaxe incomum, que dificulta a tradução. Mas eu gostei de ter traduzido esse livro, porque ele fala, basicamente do papel do intelectual no mundo contemporâneo. Ele contextualiza a posição do intelectual no século XX, e as várias formas de representação dos intelectuais, ou seja, como eles se representam a si mesmos e como desempenham a sua função.

Edward Said não acreditava na neutralidade política e faz uma abordagem das várias posições ideológicas do intelectual: de direita, conservador, progressista e até mesmo dos intelectuais cooptados, que são muitos. Ele fala também do intelectual engajado, do intelectual sartreano, fala do Julien Benda, e cita vários exemplos de intelectuais nos Estados Unidos, na Europa, no mundo árabe, ou de árabes americanos que venderam sua alma ao diabo por um preço módico, ou muito baixo. Fala também da mídia, da manipulação da imprensa no que diz respeito à política americana, à política expansionista unilateral dos Estados Unidos. E, claro, aborda também a questão palestina.

MAGED EL GEBALY: Tendo em vista seus outros trabalhos como tradutor (Gustave Flaubert e George Sand) e o fato de que a tradução é uma imagem presente no Relato de um certo oriente, qual seria - em sua opinião - o papel do tradutor literário?

MILTON HATOUM: O melhor tradutor literário é um bom escritor. Mesmo que ele não seja um escritor de ficção ou um poeta. Um bom tradutor literário tem que ter primeiro o domínio de sua própria língua, como se ele fosse capaz de escrever a ficção ou o poema que está traduzindo. É importante também contextualizar a obra. Não ler apenas o livro que se vai traduzir, mas os outros livros do autor a ser traduzido. Quando traduzi George Sand e Flaubert, já conhecia razoavelmente a obra desses escritores.

Do Flaubert há, inclusive, uma história que data da minha juventude, quando aprendi francês em Manaus, nos anos 1960. Eu era muito jovem e minha avó libanesa falava um pouco de francês, de modo que a língua francesa não era desconhecida para mim. Na minha casa se falava árabe e 
português, mas quando minha avó nos visitava, ela gostava de praticar a língua francesa. Ela estudara num liceu francófono em Beirute.

Aprendi francês com a esposa do cônsul francês em Manaus, quando eu tinha 12 ou 13 anos. Essa professora me apresentou pela primeira vez os contos do Flaubert, ela lia um trecho de Um coração Simples e depois o traduzia. Era uma maneira também de ampliar o vocabulário. A linguagem de Flaubert tem um lado preciosista, um vocabulário muito preciso e às vezes um pouco raro, sobretudo nos contos e romances ambientados na Palestina e no Norte da África. É um vocabulário incomum. Minha professora usava o texto em francês para discutir e abordar questões gramaticais, como o uso dos tempos verbais (passé simple e passé composé) na linguagem escrita e oral. Eu adorei o conto Um coração Simples. Eu gostei tanto que até uma personagem de Dois irmãos, Domingas, foi inspirada de certa forma pela personagem Félicité (de Um coração Simples). Félicité é um nome irônico porque era uma empregada doméstica explorada, desgraçada, infeliz e pobre.

MAGED EL GEBALY: Como define hoje "tradução literária"?

MILTON HATOUM: A tradução literária não é uma versão fiel do original. Existem várias teorias. Não sou um tradutor profissional, mas eu li alguns bons ensaios sobre tradução, de Antoine Berman, Valery Larbaud e Walter Benjamin. A tradução tem que transmitir a essência do original, mas ela tem que ser um texto legível na língua traduzida. A tradução ideal é aquela que o leitor percebe que não é uma tradução, que ele não está lendo uma tradução, e sim um original, um texto escrito na sua língua. Então, há graus de fidelidade.

Se você tiver uma palavra intraduzível, você deve colocar uma nota de rodapé. Se aparecer uma árvore amazônica, uma árvore que não existe em outro lugar, você deve colocar o nome dessa árvore em língua tupi ou em língua indígena num glossário ou numa nota de rodapé para explicar “essa árvore existe, é nativa da Amazônia, ela é uma palmeira ou uma árvore que dá frutos, etc." Sem tentar explicar muito, porque também uma tradução com um glossário de dez páginas deve ser chato.

Há uma sensibilidade na tradução que é você expressar essa essência do texto original, sem ser exatamente fiel a ele. Uma boa tradução deve ser ao mesmo tempo literal e livre. Berman afirma 
que a tradução deve passar pela experiência e pela reflexão, pois a tradução, como ele diz, é sujeito e objeto de um saber próprio. Por isso é difícil. É como se fosse um espelho, em cuja superfície se reflete ou se manifesta o que o texto original oculta. A pior tradução é aquela que os franceses chamam de mot à mot, palavra por palavra. Uma boa tradução deve ser ao mesmo tempo inventiva e próxima do significado do texto original, porque você não pode distorcer aquilo que está no original, mas ela tem que fluir. Então o difícil da tradução é esse fluir.

MAGED EL GEBALY: Uma tradução pode transcender a obra original ou, ao contrário, perde algo dela?

MILTON HATOUM: Uma tradução pode, sim, transcender a obra original. Há traduções maravilhosas. Quando um livro não é muito bom, uma tradução faz milagre. Por exemplo, há traduções de romances apenas razoáveis ou sem muita força que às vezes a tradução melhora. Isso acontece muito com livros mais fracos, com narrativas medianas. Agora, quando o livro tem força, quando o romance é uma obra trabalhada, aí o trabalho do tradutor também tem que ser enorme. Então sempre se perde alguma coisa. Porque o original é aquilo que, no limite, é intraduzível. Quando eu leio uma tradução árabe ou russa, sei que eu estou perdendo algumas nuances, mesmo se a tradução for muito boa. O ideal para mim seria ler tudo no original, mas como isso é impossível, como eu não posso ler nem Dostoiévski, nem Elias Khoury no original, eu tenho que confiar nas traduções. Dei exemplos de dois grandes autores que foram muito bem traduzidos para o português. Então a tradução pode transcender o original e sugerir coisas que não existem explicitamente no original. Ela pode dar, às vezes, até mais consistência ao original.

MAGED EL GEBALY: Quais são os leitores de Milton Hatoum?

MILTON HATOUM: Eu não sei exatamente quem são meus leitores, mas isso também varia de um romance para outro. $\mathrm{O}$ meu primeiro romance, Relato de um certo oriente, não alcançou um número muito grande de leitores. É mais difícil de ser lido; o leitor tem que descobrir a voz do personagem e quem está falando. Então, um leitor médio não tem paciência para ir atrás dessas coisas. Por isso, esses leitores do Relato de um certo oriente são mais ligados ao mundo acadêmico e também às escolas. 
Com o Dois irmãos aconteceu uma coisa interessante: foi um romance que recebeu muitas críticas positivas e, ao mesmo tempo, alcançou um público leitor que transcende o âmbito universitário e acadêmico. Então, hoje, é um livro que deve ter pelo menos uns 150 mil leitores. Para o padrão brasileiro e para um romance que, supostamente, não é comercial, é um número significativo.

Não pensei em escrever nada comercial, nem sei exatamente o que é isso. Mas é difícil saber quem são os leitores. Eu encontro todo tipo de leitor, mas poucos são ingênuos. Às vezes, você nem precisa ter muitos leitores, se os seus leitores forem fiéis e se gostarem de literatura...

MAGED EL GEBALY: Em que diferiria a leitura dos seus tradutores das dos outros leitores?

MILTON HATOUM: Os tradutores são leitores muito especiais. Primeiro porque são leitores que já lêem o livro pensando na tradução. Eles têm que ler duas, três, ou várias vezes o livro. Já é uma leitura interessada, uma leitura em filigranas. Esse leitor-tradutor-escritor já tenta perceber desde a primeira leitura as nuances, as sutilezas, e as dificuldades que ele vai ter.

Eu tive sorte com muitos tradutores, porque entram em contato comigo. Isso aconteceu com os tradutores do francês, que não é o mesmo dos quatro romances. Michel Riaudel traduziu, para o francês, Cinzas do Norte e Órfãos do Eldorado. Ele é um grande tradutor, assim como Karin von Schweder-Schreiner, que traduziu todos os romances para o alemão. Karin já conhece o meu trabalho, então ela me faz perguntas muito específicas. Nas traduções italiana (de Amina Di Muno) e inglesa (de John Gledson) também aconteceu isso. Com a tradutora do espanhol (da Espanha) eu não tive nenhum contato. Para ser sincero, não apreciei essa tradução. A tradutora não tinha vivência da sociedade brasileira e da língua portuguesa falada e escrita no Brasil. Adriana Kanzepolsky, a tradutora argentina, que mora em São Paulo e é professora da USP, manteve contato comigo. É uma tradução muito mais fluente, muito mais verdadeira que a tradução espanhola (da Espanha). As traduções do Relato e do Dois irmãos publicadas pela editora argentina Beatriz Viterbo são muito consistentes.

MAGED EL GEBALY: Como seus tradutores conheceram sua obra e como é o processo da tradução das suas obras? 
MILTON HATOUM: Meus tradutores conheceram minha obra porque leem a literatura brasileira contemporânea. São sempre tradutores de literatura brasileira e portuguesa, alguns só de literatura brasileira. Eles se interessam pelo que é publicado no Brasil. Eu conhecia alguns desses tradutores, que não são muitos. Conhecia os ensaios de John Gledson, que traduziu todos os meus livros para o inglês, menos o Relato de um certo oriente, que foi traduzido por Ellen Watson, professora do Smith College (EUA). Não há tantos tradutores de literaturas de língua portuguesa. Talvez haja bem menos do que tradutores do árabe, porque o árabe hoje é uma língua que conta com uma tradição do seu ensino na Europa e nos Estados Unidos. Então há vários tradutores do árabe na Europa e nos Estados Unidos, mais do que do português. Quando eu vejo os livros árabes traduzidos para o inglês, francês, italiano, alemão, percebo que foram traduzidos por diferentes tradutores. Há escolas e cursos de árabe nas universidades da Europa e dos Estados Unidos. E aqui nós já temos também bons tradutores do árabe.

Mantenho uma correspondência direta com a maioria de meus tradutores. Respondo a muitas perguntas, tento esclarecer dúvidas, muitas delas sobre expressões da Amazônia, que não são conhecidas em outras regiões do Brasil.

MAGED EL GEBALY: Em que medida o senhor interfere nas traduções?

MILTON HATOUM: Interfiro na tradução na medida em que encontro equívocos, uma distração aqui e ali, palavras de duplo sentido, coisas que o tradutor não percebeu. Posso dar dois exemplos.

No Dois irmãos há uma cena em que Domingas, a empregada, segue um dos irmãos (Yakub) e a namorada dele (Lívia) até o quintal da casa. Eles vão se despedir porque Yakub vai viajar para São Paulo. Domingas se aproxima, fica meio amoitada, meio escondida vendo os dois ali, namorando, e ela fica com sede daquela água . A tradução dizia que Domingas queria tomar um copo de água. Então eu observei que a sede daquela água era a sede de desejo, uma sede erótica, sexual.

Outro exemplo: no Cinzas do Norte, quando aparece uma nuvem de mosquitos, a tradutora cometeu um equívoco: ela confundiu os mosquitos (inseto) com os índios da tribo mosquitos, o que seria um absurdo no contexto do romance. Então, às vezes, o tradutor cochila, desfalece enquanto está traduzindo. Ou fica um pouco distraído e de repente pula um parágrafo. Isso é 
comum. Eu já vi isso em várias traduções. Quando você está traduzindo, por distração você não segue a sequência e salta umas frases ou um parágrafo.

MAGED EL GEBALY: Relato de um certo oriente já foi traduzido para que línguas?

MILTON HATOUM: O Relato de um certo oriente foi publicado em 1989. O primeiro país que se interessou em traduzir foi a França. Ele foi traduzido primeiro para o francês, depois para o inglês, italiano, alemão, espanhol. Saíram nesses países da Europa e também na Suíça, em Portugal e nos Estados Unidos. E vai ser publicado em catalão. Há um contrato com uma editora grega que já publicou Dois irmãos, mas não sei em que pé está. Às vezes uma editora compra os direitos de um livro, mas não o publica. Ainda não foi traduzido para o árabe.

Há duas edições do Relato em língua inglesa: uma tradução de Ellen Watson para o inglês dos Estados Unidos. Depois John Gledson revisou essa tradução com a própria Ellen, e essa nova tradução saiu na Inglaterra, em capa dura e edição de bolso. A primeira versão americana tem como título The tree of the seventh heaven, "a árvore do sétimo céu", que é uma frase do livro. Achei estranho esse título. A edição inglesa (Bloomsberry) saiu com o título Tale of a certain orient, que é mais próximo do título original.

MAGED EL GEBALY: Como foi o processo de tradução e qual foi a recepção de Dois irmãos pelo leitor de língua árabe?

MILTON HATOUM: Na tradução árabe de Dois irmãos, conversei muito com a tradutora e professora da USP Safa Jubran. Safa é bilíngue, domina muito bem os dois idiomas e traduz nos dois sentidos: do português para o árabe e do árabe para o português. Sei que algumas resenhas e artigos elogiaram a tradução de Safa. Um cineasta disse a ela que parecia um romance escrito por um autor libanês. Essa observação não deixa de ser interessante. Já havia saído no Líbano um artigo sobre o Relato de um Certo Oriente, que um crítico libanês leu em francês e fez uma comparação com o livro de Jorge Amado A Descoberta da América pelo Turcos, sobre os árabes que vieram ao Brasil na época do descobrimento. 
MAGED EL GEBALY: Quais são os problemas que podem encontrar os tradutores na construção dos romances de Milton Hatoum, especialmente no Relato de um certo oriente?

MILTON HATOUM: A minha tradutora alemã Karin von Schweder-Schreiner me disse uma coisa interessante : "por trás dessas frases límpidas, aparentemente simples que você constrói, há uma dificuldade imensa. Eu encontro uma dificuldade para traduzir o livro porque, às vezes, para um tradutor alemão, a falta de precisão do português do Brasil pode confundir um pouco e dificultar a tradução ”. A língua portuguesa do Brasil é muito menos retórica. Por exemplo, quando não se usa no começo da frase o pronome pessoal ("ela via, ele disse") o tradutor pode confundir o sujeito da frase. No caso do Relato, deu-me trabalho montar um quebra-cabeça sobre as vozes narrativas, mas nas edições inglesa e francesa está indicada a voz do narrador na abertura de cada capítulo.

Essa é uma dificuldade que os tradutores enfrentam. O fato de o português do Brasil ser muito maleável e flexível dificulta o trabalho de tradução, porque nem tudo é muito determinado, os pronomes, o sujeito mesmo, quem fala... O português do Brasil é muito menos retórico do que o de Portugal, que é uma variante que tem muito mais precisão, muito mais exatidão.

Você lê um texto em português de Portugal e é quase como se você pudesse traduzir para o português do Brasil, porque seria uma linguagem muito menos arcaizante, muito menos retórica do ponto de vista da sintaxe, da gramática. Então isso pode dificultar um pouco a tradução.

MAGED EL GEBALY: Que tipo de escrita existe em Relato de um certo oriente e o que significa "narrador transcultural" na configuração discursiva do Relato?

MILTON HATOUM: O Relato de um certo oriente é como os franceses chamam "um relato de memória", de tom evocativo. Há uma frase de um personagem no Relato que diz "a vida começa verdadeiramente com a memória”. Ao mesmo tempo, é uma longa carta que a narradora estava escrevendo para o irmão em Barcelona. Seria então um romance epistolar?

Não sei. Esse lado transcultural, como muitas vezes foi analisado, reside no fato de o romance se situar em Manaus e ter personagens imigrantes, árabes, judeus marroquinos e às vezes índios. 
MAGED EL GEBALY: Por que escreve?

MILTON HATOUM: Para mim a literatura dá sentido à minha vida. São poucas coisas que dão sentido à nossa vida e das poucas coisas a literatura é das mais importantes. Escrevo com desejo, com paixão. Eu escrevo à mão de manhã cedo. Eu sei a que horas eu começo a escrever, mas nunca sei a que horas vou parar. Eu levo muito a sério a literatura, mas eu mesmo não me levo a sério. Não tenho a pretensão de ser um escritor representativo ou das academias. Não tenho nenhuma pretensão ao pedestal, nem à respeitabilidade. $\mathrm{O}$ escritor que se leva muito a sério se torna um pouco patético. Não tenho essa pretensão. Os prêmios também não me entusiasmam muito. O que mais me entusiasma é ter bons leitores. Acho que isso é o mais importante.

A literatura é apenas um dos modos de você ver o mundo, de você transformar esse mundo através da linguagem. E a literatura cria um mundo paralelo, um microcosmo paralelo. E talvez muito mais coeso, muito mais organizado, e, às vezes, dotado de uma verdade interior mais forte do que a nossa realidade. Então, ela não é uma imitação do mundo, nem um retrato nem um processo mimético do que a gente viveu, mas é a transcendência de tudo isso pela linguagem. A literatura fala basicamente da passagem do tempo, filtra uma experiência do autor, que é transferida para o narrador.

Nem tudo que a gente viveu cabe na literatura, então você tem que filtrar essa experiência e dar sentido a ela. Dar sentido com coerência interna, com uma estrutura bem armada. Isso é que é difícil, porque você julga um livro não pelo que o autor é ou pelo que ele fez ou faz ou diz, e sim pela linguagem. Agora, é claro que alguma coisa de mim, da minha vida, está presente nos meus romances e nos contos.

MAGED EL GEBALY: Como passou da narrativa longa (romances e novelas) para a narrativa breve presente em Cidade Ilhada? Como foi a passagem do conto Reflexões de uma viagem sem fim para o romance Relato de um certo oriente? E, finalmente, como foi transformar A natureza ri da cultura no seu último livro a Cidade ilhada?

MILTON HATOUM: Comecei de verdade como contista, só que não publiquei meus contos. Os contos que eu escrevi na década de 1970 foram todos abandonados e depois foram esquecidos; eu 
joguei tudo fora. Então, o primeiro que eu quis terminar foi Reflexões de uma viagem sem fim, concluído quando o romance foi editado.

Reflexões sobre uma viagem sem fim foi a primeira versão do Relato de um certo oriente. Não publiquei esse conto quando comecei a escrevê-lo em 1980. Depois eu voltei para o conto, reescrevi e republiquei dando outro título A natureza ri da cultura, que faz parte do livro $A$ cidade ilhada. É um conto que já foi publicado no exterior com o título Reflexões sobre uma viagem sem fim, mas este conto não é o mesmo que está no livro. Quer dizer, é basicamente o mesmo, mas mudei várias passagens e abreviei muita coisa.

MAGED EL GEBALY: Como dialoga com a tradição literária para criar sua escrita?

MILTON HATOUM: Minha tradição faz parte da literatura. Eu comecei lendo livros brasileiros: Vidas Secas, de Graciliano Ramos; Jorge Amado; Os Sertões, de Euclides da Cunha; $O$ Continente, do Érico Veríssimo; depois eu comecei a ler os contos do Flaubert, os contos do Machado de Assis, e aí a literatura é muito vasta, tem muita coisa da França, da América Latina, da Europa, do Mundo Árabe, que era muito carente por falta de traduções.

É difícil dizer quem me influenciou. Todos eles influenciam de alguma maneira. É claro que você, às vezes, é influenciado por um autor pelo qual você nem percebe que está sendo influenciado. E, às vezes, por um autor que você nunca leu, para usar uma boutade (ironia) de Jorge Luis Borges, você pode ser influenciado por um livro que nunca leu. Machado de Assis antecipou o que Borges faria meio século depois, mas consta que o escritor argentino nunca leu o brasileiro.

É difícil ser original hoje. Borges é muito irônico, com a pretensa originalidade que alguns autores buscam. Depois de algumas centenas de anos de romance moderno, é difícil ser totalmente original. Eu não acredito na originalidade absoluta. Um dos atributos do ser humano é copiar. No começo, você copia e aprende copiando. Depois você tenta encontrar sua própria voz, e é isso que dá sentido à originalidade de um texto.

MAGED EL GEBALY: Como a ditadura militar dos anos 1970 é abordada em seus romances Dois irmãos e Cinzas do Norte? 
MILTON HATOUM: A ditadura e o quadro histórico são apenas panos de fundo desses dois romances, porque nenhum dos dois é um romance histórico, nem um romance político. Mas esse pano de fundo existe e é importante até para contextualizar a narrativa. Faz parte também da minha vida, da minha geração, que vivenciou essa época, que cresceu durante o regime militar, sobretudo no Cinzas do Norte, onde há as relações do pai de Mundo com os militares, relações muito fiéis e comprometedoras.

Então, alem do conflito com o pai, o personagem Mundo esbarra na relação do pai com os militares. É uma dupla tirania, a do pai e a do país, isso é importante nesse romance. Mundo se depara com um ambiente adverso em Manaus, onde o pai, a província e o regime militar o oprimem. Ele é um "estranho" em sua própria terra. Mas anos depois, quando mora em Berlim e Londres, ele se torna um autoexilado, um expatriado com pouca interlocução, e cerceado pela imagem sufocante do pai. É um estrangeiro, sem eira nem beira, pois não desfruta da herança de Jano. De certo modo, ele faz o percurso que alguns da minha geração fizeram: de Manaus (ou qualquer outra cidade periférica), para o Rio ou São Paulo e depois para a Europa.

No Dois irmãos, a ditadura militar está presente, há a morte de um poeta, um professor de francês assassinado pela repressão. Um dos irmãos acredita na política desenvolvimentista, no progresso a todo custo, acredita nessa enganação que foi o regime militar, o milagre econômico. Então, são coisas importantes para os livros, mesmo porque o romance precisa trabalhar com o sentido da história. O romance não pode ser uma coisa totalmente solta no tempo.

MAGED EL GEBALY: Como cidadão, qual sua opinião sobre a política e a democracia nos países árabes hoje?

MILTON HATOUM: Do ponto de vista geopolítico, Egito e Arábia Saudita são os países mais fortes do Mundo Árabe. O caso do Egito, sendo o maior país árabe (ou dividindo essa grandeza territorial com a Argélia), é mais complexo porque os interesses de Israel e dos Estados Unidos são muito grandes ali.

Acompanhei a vergonhosa restrição do regime no Egito à passagem de mantimentos básicos (alimentos e remédios) para a população palestina em Gaza. Trata-se de uma ditadura que serve aos interesses da política americana. 
O povo egípcio quer um regime democrático, mas será que as forças armadas querem? O expresidente Sadat, e o atual vieram das forças armadas. É muito imprevisível se as forças armadas do Egito vão aceitar o filho dele como sucessor, ou se haverá um golpe de Estado no interior das forças armadas. Os palestinos elegeram um governo democraticamente, mas a "comunidade internacional" não aceita o Hamas.

Acho que um governo democrático na Palestina incomoda a autocracia do Egito. Para os Estados Unidos e Israel é conveniente que haja no Egito um regime autoritário, pró-israelense e próamericano. É vergonhosa e totalmente hipócrita essa aliança estratégica da política externa do governo americano com as ditaduras no Mundo Árabe.

O governo de George W. Bush quis instaurar a democracia ao Iraque e, no entanto, os aliados árabes dos Estados Unidos são governos autoritários, com a exceção do Líbano, cuja democracia é frágil. Bom, essa história de levar democracia a um país rico em petróleo é pura balela. Como disse Robert Fisk: "Se o Iraque fosse o maior produtor de batatas, o governo de G.W. Bush não teria invadido e ocupado o país."

A Europa é dividida quanto à política no Oriente Médio: a França não tem a mesma posição que a Inglaterra, mas ambas foram potências coloniais e são também responsáveis por essas atrocidades. A Espanha não tem a mesma posição que os Estados Unidos e me parece que é o país europeu mais comprometido com a paz na região.

A gente vê hoje isso como algo que lembra muito o regime militar no Brasil e na América do Sul. Cedo ou tarde a democracia vai chegar ao Mundo Árabe, mas não será uma democracia imposta, os povos árabes vão conquistá-la. A tendência é esses países se democratizarem, mas será uma democracia a custo de muita luta.

Conheço a militância da feminista egípcia Nawal al Saadawi ${ }^{16}$ que lidera corajosamente um movimento de liberação das mulheres contra este regime. E me encontrei em dois eventos literários (em Nova Iorque e Berlim) com o também escritor egípcio Alaa Al Aswani ${ }^{17}$. Alaa é

\footnotetext{
${ }^{16}$ Nawal Al Sadawi (n. Cairo, 1930-...) é ativista feminista da esquerda egípcia. Ganhou fama internacional por suas críticas às ditaduras do Oriente Médio apoiadas pelos Estados Unidos.

${ }^{17}$ Alaa al-Aswany(n. Cairo, 1959-...)Escritor egípcio e um dos líderes do Movimento Egípcio pela Mudança Democrática. Notabilizou-se por seu romance Edificio de Yaqubian, traduzido e publicado pela Companhia das Letras, em 2009. O romance foi adaptado para o cinema no Egito e protagonizado pelo ator egípcio Adel Emam.O romance de Alaa Alswany faz crítica aos setores conservadores da sociedade egípcia.
} 
corajoso, como tinha sido Naguib Mahfouz, que criticou os radicais islâmicos e pagou caro por isso.

MAGED EL GEBALY: E quais são os seus contatos com o Líbano?

MILTON HATOUM: Tenho parentes no Líbano, país que visitei com meu pai em 1992 e que ele não visitava havia mais de 30 anos. Então foi uma viagem muito emocionante porque eu conheci o país dele; conheci muitos parentes, primos, tios. Há dezenas de familiares em Beirute. Infelizmente não falo árabe, mas na temporada que passei no Líbano viajei por vários lugares do país e conheci muitas coisas. Já não era o Líbano de que meu pai falava, mas é um país muito bonito, com uma grande diversidade cultural e uma história que se assemelha a um palimpsesto. Os libaneses têm várias origens étnicas, e nisso se parecem com os brasileiros. São povos híbridos e, no caso do Líbano, a religião ocupa um papel importante na política e na distribuição do poder. Em minha opinião, um Estado deve ser laico. Naquele ano (1992) foi triste ver Beirute em ruínas. A cidade já foi reconstruída, mas o que eu vi foi uma paisagem depois de uma guerra. É uma coisa terrível. Conheci Sabra e Chatila, andei pelos acampamentos palestinos; fui ao Sul do Líbano, até onde pude.

Conheci a aldeia do meu avô paterno. Fui à Trípoli, ao Norte, enfim, eu conheci muita coisa do país. Foi uma viagem de conhecimento e também afetiva. Uma espécie de descoberta do meu passado mais ancestral. O Líbano é um pequeno recorte do Mediterrâneo com muita área verde, montanhas, e sem região desértica. $\mathrm{O}$ clima é maravilhoso, pois combina a temperatura à beiramar (Mediterrâneo) com um clima mais temperado das montanhas.

O Mundo Árabe se parece com o Brasil. Existe uma informalidade nas sociedades árabes que lembra um pouco o Brasil, e o modo de ser brasileiro. É uma coisa meio informal, ou às vezes um pouco caótica. Talvez a gente deva isso a um passado muito distante, ibérico.

MAGED EL GEBALY: Para concluir: quais os projetos que tem em mente?

MILTON HATOUM: Estou organizando e selecionando algumas crônicas para um livro que pretendo publicar. E há três anos escrevo um romance. Escrevo outras coisas, relatos que podem ser contos, crônicas ou ficções. O gênero não importa, é a linguagem que interessa na literatura. 


\section{Anexo 2: Resumos do minicurso "DO ROMANCE À NARRATIVA BREVE" Ministrado pelo Milton Hatoum em Casa do Saber (Para ser aproveitado neste capítulo)}

\section{Professor: Milton Hatoum - Aula 01 - 25/08/2009}

Enquanto Hatoum escrevia seu primeiro romance publicado, se deparou com algumas dificuldades. A primeira delas foi reconhecer que o passado recente não era bom para o romance, teve que ignorar as décadas de 1970 e 1960 para que tudo soasse como ele pretendia. Influenciado pelas leituras que fazia na época, o escritor buscava uma narrativa que imitasse um conto memorialista, era isso que ele queria escrever.

$\mathrm{Na}$ primeira tentativa, começou a compor um romance em terceira pessoa, mas acabou percebendo que o mundo da subjetividade na ficção se adequava melhor à primeira pessoa do singular. A terceira soava falso, estava fora do tom.

Nesse contexto, tom é a atitude do narrador em relação ao que é narrado. Hatoum percebeu também que o narrador masculino também soava falso e então enfrentou a dificuldade de reproduzir o tom de uma mulher.

Em um terceiro momento, o artista percebeu que não queria que o romance fosse dramatizado, com muitas cenas, pois, considerando Aristóteles, queria que soasse como uma forma direta e não indireta (drama). Isso além de querer que todas as personagens falassem na primeira pessoa.

A solução para essas questões foi a narrativa epistolar que, ao invés de dar dramaticidade ou tons a todas as vozes, inscreve todas na mesma voz. E o narrador pode atingira vários graus de envolvimento com a ação.

Umas das considerações mais importantes que adquiriu pelas leituras foi que saber dar o tom mais adequado à enunciação é crucial, pois ele indica a visão de mundo do narrador. O romance 
fala de um mundo particular a um leitor particular, o universal é pura abstração que só existe depois que se ultrapassa o particular, a teoria não interessa à trama do romance.

A clareza interna da narrativa se dá pelo narrador e a relação entre ele e as personagens. Hatoum acredita ter perdido muitos leitores porque o enredo de Relatos de um Certo Oriente não é muito claro e a mudança de narradores é grande, mas afirma que quis armar um quebra cabeça com as vozes, queria escrever uma coisa densa e complicada como todo jovem. Não poderia ser outra forma. A essência do romance está na sua linguagem, na sua estrutura e, se fosse escrito de outra forma, seria outro livro.

Em 1990, o escritor começou a compor uma espécie de saga, um romance com estilo contrário ao de seu livro publicado. Passou cinco anos escrevendo um romance de 700 páginas que nunca publicou, uma alucinação amazônica, uma espécie de confrontação de textos transatlânticos. Aquela foi a época que gostava de ler romances enormes. Mas publicar o texto precisaria de um processo exaustivo de re-escrita. Hatoum prefere romances com traços autobiográficos porque são aqueles que apresentam maior relação do narrador e enredo. É bom lembrar, diz o escritor, que uma vida intensa e atribulada não necessariamente se relaciona com a intensidade da arte. A totalidade da vida é menos necessária que o momento.

Depois da leitura de Esaú e Jacó, Hatoum teve a ideia de outro romance com maior trançado de eventos e problemas, Dois Irmãos. Um livro onde os eventos de uma casa interagem diretamente com uma cidade e um país. De história conflituosa com várias cenas, Dois Irmãos tem um narrador de classe média (fronteira social entre a elite e o proletariado) que cresce fisicamente, uma figura machadiana, um agregado e ilustra o mito da rivalidade. Foi o livro que permitiu ao escritor passar a viver de literatura.

Hatoum afirma que "um escritor tem que ser um bom leitor. Há 1000 maneiras de se ler um livro, a questão é conseguir encontrar as várias dimensões adjacentes dele, ou seja, não se pode ser um leitor ingênuo". 


\section{Professor: Milton Hatoum- Aula 02 a 26/08/2009}

O livro Cinzas do Norte começa pelo fim, com a morte, assim como o Dois Irmãos, para quebrar o modelo do século 19. Ele é um painel sobre o impasse de uma relação, de uma amizade, de um conflito político e do mundo de um artista.

Por Cinzas do Norte não ser um romance histórico nem político, o autor tentou deixar umas dicas do momento que se estava retratando. As imagens da infância ou do que aconteceu na juventude do escritor em Manaus foram fonte para boa parte do livro.

Hatoum diferencia narrador de autor, diz que aquele é quem conduz a história, às vezes, de forma imprevisível. Também dá uma dica das construções de suas personagens ao dizer que uma personagem é uma construção que passa por aquilo que você quer dela e não por uma imitação do mundo real, nunca é constituída de uma pessoa só. Elas podem salvar um romance, porque tudo passa por elas, são grande fio condutor. Devem ser formadas a partir de uma concepção, mas podem se desenvolver com o tempo.

As expectativas de gênero também nem sempre são supridas. A novela é um dos gêneros mais difíceis de construir porque é quase não-classificável. Adorno coloca esse tipo de narrativa como o melhor dos gêneros contemporâneos. Menor que o romance e maior que o conto, a novela contém reviravoltas na vida das personagens e o fim contundente, é uma narrativa densa, concisa e tensa com um conflito ela lembra o drama (o teatro). Já o conto é uma espécie de mandamento da brevidade. Intenso, o conto do século 19 era característico pela surpresa no final. Ele contém uma técnica cinematográfica muito bem executada por Machado de Assis, na perspectiva de Hatoum.

Outros bons contistas e que influenciaram o trabalho do escritor são Julio Cortázar de cujos contos apresentam intensidade, tensão e significação além de alguns aspectos do conto breve trabalhados como cena dramática; Borges, que demonstra bem a relação entre literatura e história 
- grande influência para os contos de A Cidade Ilhada; Machado de Assis; Juan Carlos (Uruguai); José Roberto Mellen; Clarice Lispector; Lygia Fagundes Teles; A S. Byatt; Catherine Mashuts, entre outros.

Os contos do autor também levam em consideração a teoria de Ricardo Pilla, em "Formas breves", que afirma haver no conto uma história subjacente à narrada que ilumina o conto contemporâneo e que o torna mais complexo.

Órfãos do Eldorado é uma história de amor. Une o pai ao ciclo da Amazônia e ao cargueiro, no desenrolar do enredo. Para este livro, Hatoum teve de fazer o trabalho de editor, pois escreveu uma história muito longa e voltou cortando. Por isso, hoje, acredita que os cortes devem ser severos para prevalecer a arte de dizer muito com poucas palavras.

O escritor não sofre, mas tem muito trabalho, uma vez que a frase bem escrita nunca é a primeira versão.

O conto Natureza ri da Cultura foi o ponto de partida para o livro Relatos de um certo Oriente. O livro A Cidade Ilhada reúne contos de 17 anos.

Segundo Hatoum, cada frase, parágrafo e palavra têm importância muito grande no conto, por causa da forte relação entre conto e lírica. Ele é uma espécie de abreviação do mundo, e deve ter alcance geral.

$\mathrm{O}$ escritor avisa "tenho vícios, quase cacoetes de linguagem, que desagradam às editoras, mas elas geralmente têm razão. $\mathrm{O}$ editor é uma figura fundamental diferentemente do revisor, que cuida de problemas técnicos". 
Anexo 3: Mostra da tradução árabe da metade de Relato de um certo oriente (Capítulos 1, 2, 3, e 4) de oito capítulos

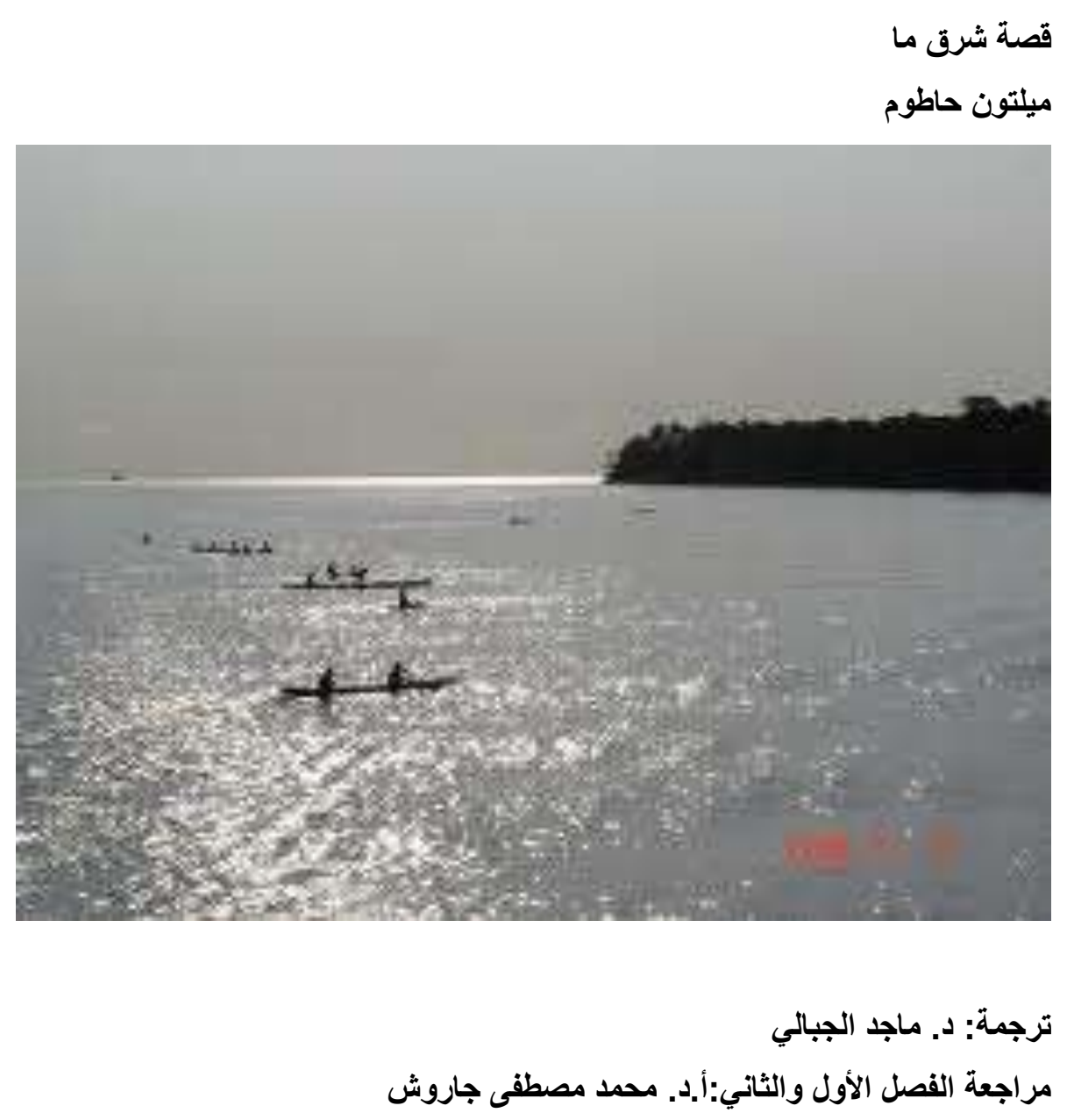


لذكرى سعدة و فاضل و لأبواي و لريتا 
Shall memory restore The steps and the shore The face and the meeting place; W.H.Auden 18

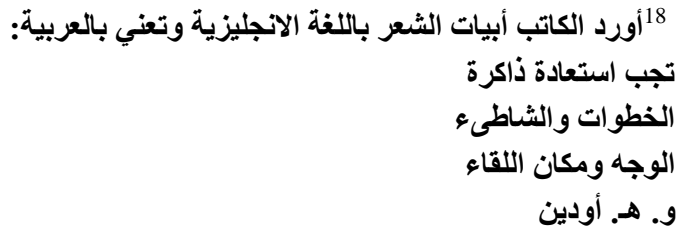


عندما فتحت عيناي، رأيت شبحي أمرأة وطفلة. الصورتان كاتتا هامدتين أمامي، والضوء الحائر للصباح الملبد بالغيوم يعيد الجسدين للنعاس ولمشقة ليلة مؤرقة. دون أن أثشر، ابتعدت عن المكان المختار للنوم ودخلت في نوع من الأيائك، بين كرة المصباح الضوئي والأيكة المؤدية للجزء الخلفي من البيت. مستلقية على العشب بجسدي المنكمش بسبب ريح باردة، كان جلاي يشعر بالملابس الرطبة ويداي موضوعتان على صفحات رطبة كنلك لافتر مفتوح حيث كنت قد شخبطت وأنا شبه

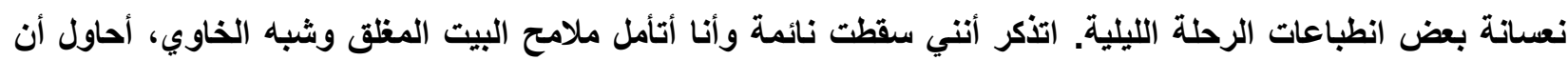
أستبصر الأسدين الحجريين بين شجر المانجا المصطف على الجانب الآخر من الطريق.

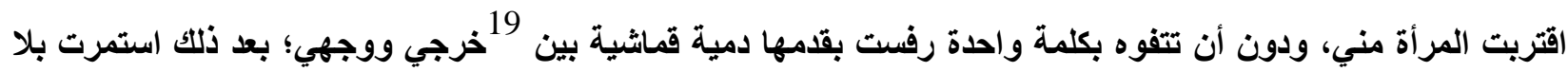

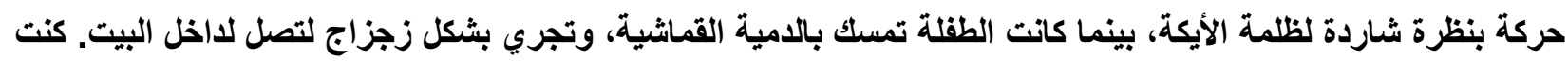

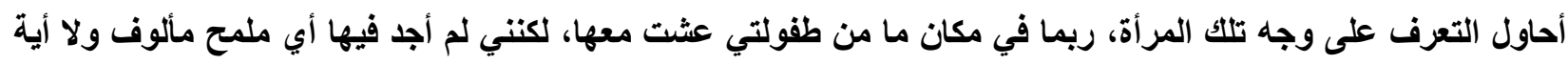
علامة تحيلني للماضي. عندما وصلت، قلت لها من أنا وسألتها عن اسمها. فأجابت: أنا ابنة أناستاسيا وإحدى بنات اميلي بالتبني.

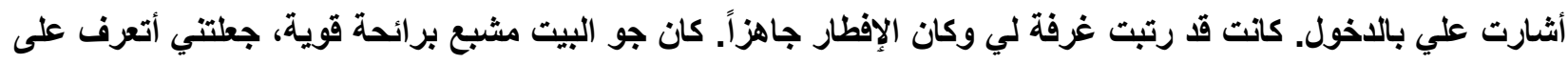
الفورعلى لون الفواكه وكثافتها وشكلها وطعمها، التي كنا نلتقطها من الأثجار المحيطة بفناء البيت الآخر. قبل الاخول لغرفة الطعام، قررت أن ألقي نظرة على حجرات الدور الأرضي. كانتا حجرتين متجاورتين ومستقلتين عن باقي البيت. فضلاً عن عتمتهما، كاتتا مكتظتين بالأثاث، والكراسي الوثيرة، ومزينتين بسجاجيد كاثشان وأصفهان، وفيلة هندية من البورسلان المصقول تثع ببريقها، وصناديق شرقية بها حفر بارز لتنين على جوانبها الخمسة.الحائط الوحيد الذي لم يكن يزدان التهان

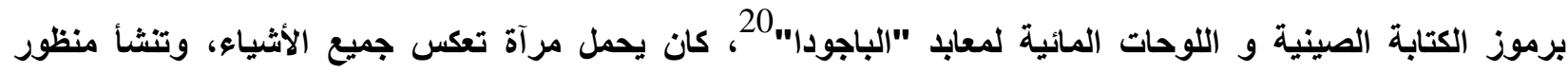
فوضوي لكتل الأثياء، التي يتم تتفيضها وتلميعها كل يوم، كما لو كان ذلك الجو لا يعترف ببقاء أو حتى عبور أي أحد.

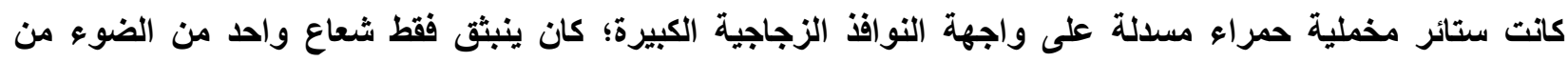

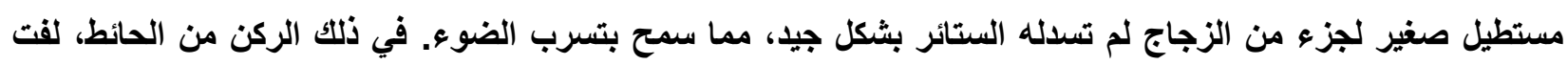
انتباهي قطعة ورق. بدت شخبطة طقلة معلقة على الحائط على مسافة تزيد بقليل من المتر من الأرض: من بعيد، كان

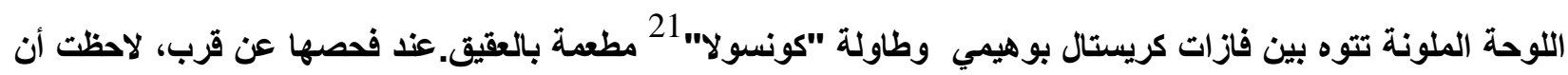
البقعتين الملونتين مكونتان من آلاف الخطوط ، مثل روافد صغيرة من حزامين مائيين من مختلف الظلال اللونية؛ شكل

من استعمل الكاتب (Alforje) وهي كلمة غير شائعة الاستخدام في اللغة البرتغالية وهي مشتقة من العربية (الخرج) وتعني في البرتغالية حقيبة سفر

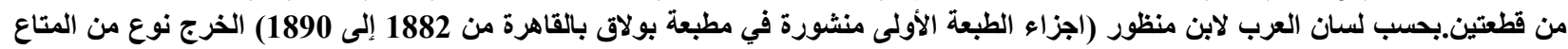

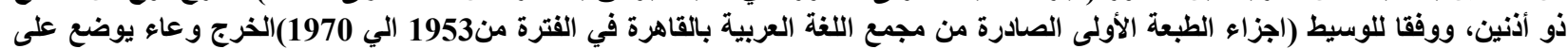

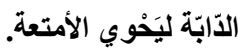
(pagode) 20 (consolo) $)^{21}$ 
رهيف، تثكله خطوط قليلة، كان يجدف في زورق قد يكون بثكل جيد داخل المياه أو خارجها بدت وجهته غير محددة، لأنه لم تكن هناك أية علامة في الرسم على مقصد حركة الزورق. وبدت القارة أو الأفق خارج اللوحة الورقية.

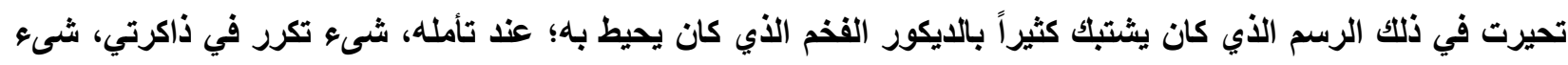

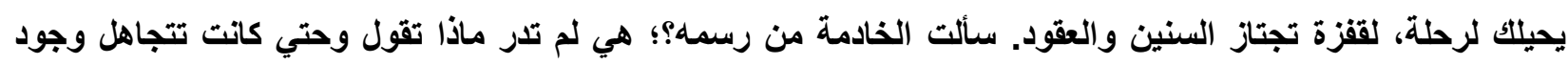
اللوحة الورقية في الصالة حيث كانت تدخل كل صباح للتظيف. انتقلت في حينها للاستفسار منها عن الحياة في المدينة، وإن كاتت الطفلة ابنتها أم أبنة زوجها، لكن عند عصفها بوابل من الأسئلة كاتت تطلق نخرة و تقتصر من جديد على صمتها

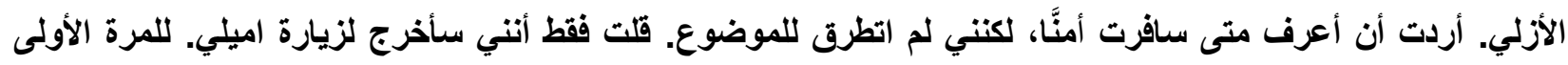

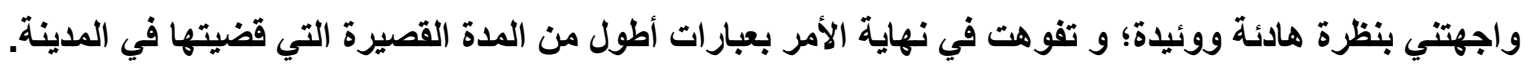

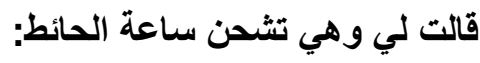
خذي لها قليل من العل الأبيض الريفي، فهو أحب الأثياء لها.

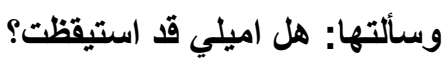
يقولون أن جدتك منذ وقت طويل لا تتام، فهي تحلم ليل نهار بك وبأخيك وبالأسماك التي ستثتريها من السوق في

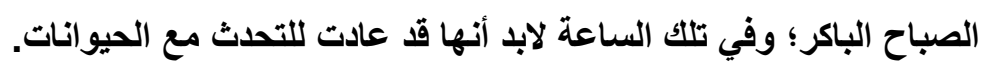
الحيث مع الحيوانات وأحلام اميلي، مشوار السوق في الساعة التي تكثف فيها الثمس عن أطياف عديدة من اللون

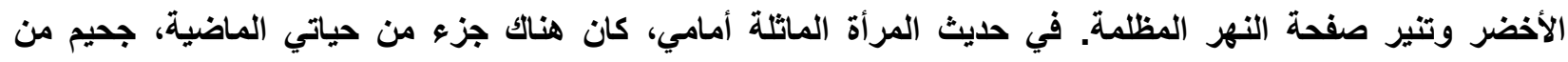

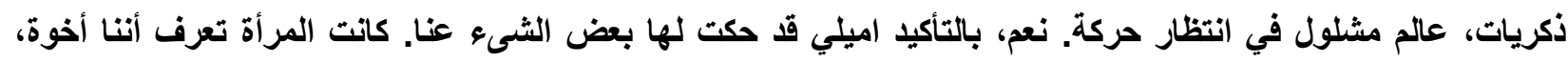
وأن اميلي قد تبنتا. قد تكون قد عرفت بالفعل عن وجود أربعة أبناء لاميلي: حكيم وسمارة ديليا اللانان صارا خالينا،

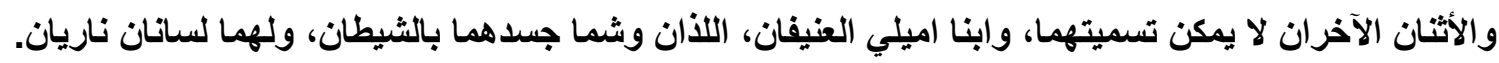

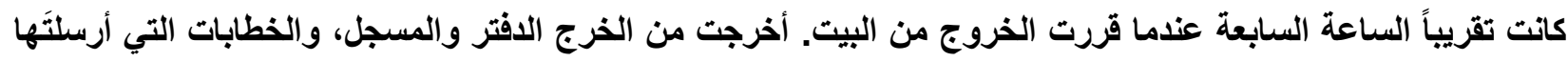

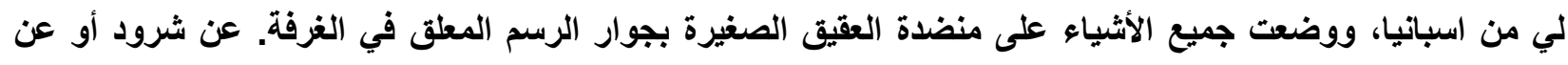

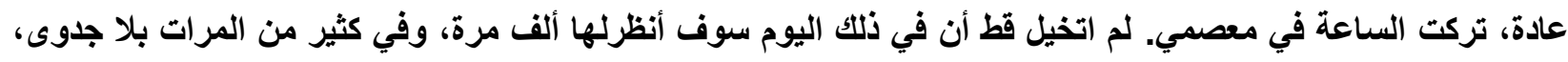

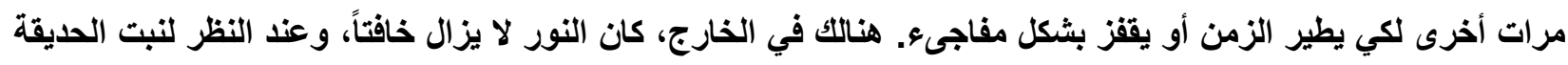
الساكن، ارتتت المرأة:"فقط ستمطر في وقت لاحق".

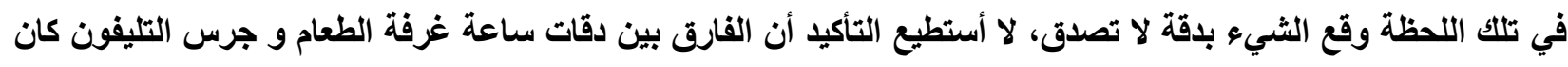

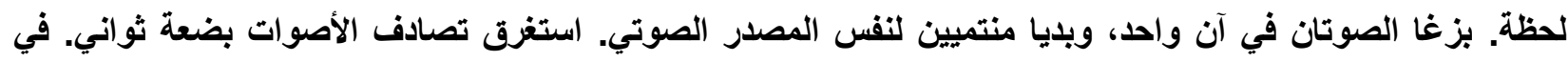

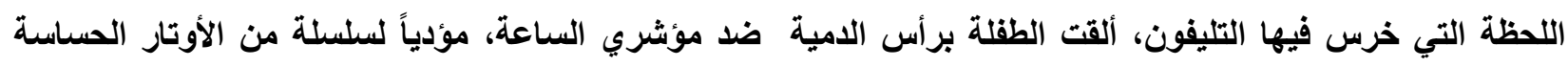

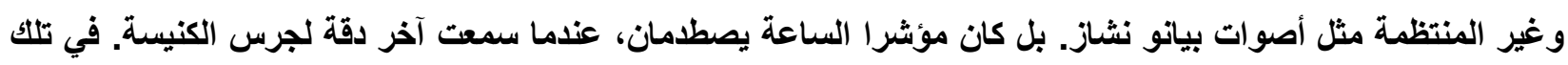
الآونة فقط جريت للرد على التليفون، لكنني لم أسمع أي شىء إلا الضوضاء التهاء وتداخل الأصوات.

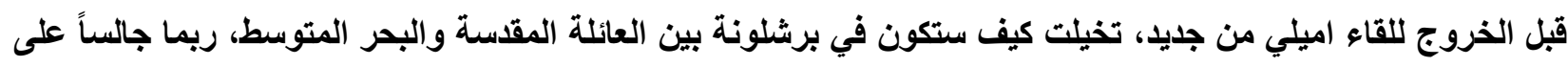

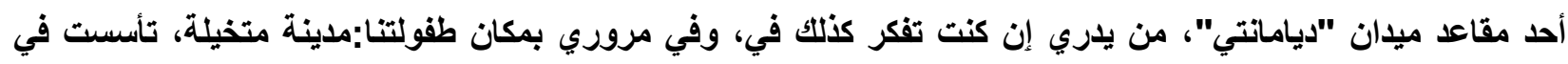


كنت لا تزال تحبي في عيد الميلاد22 ذلك لسنة 1954، و ثريا أنجيلا كاتت رفيقتي. دائما كنت تبكي عند ظهورها، تريد أن تلعب معك و أن تلاطقك. في الحقيقة نظرتها المرتعبة، وإيماء|تها الفظة تبث الخوف في قلب أي أحد. أذكر أنها كاتت منبوذة من أطفال الجيران وهي نفسها كانت تثعر بذلك فكاتت تستسلم للعب مع الحيوانات وتقوم بأعمال شيطانية معهم، تمتطي الغتم وتقرص أذنها، وتثبك ذيول القرود. كانت تؤذيها بإندفاعةٍ مخيفةٍ بحق وحقيقي، لكن بعد ذلك كانت تضحك وتهديء وتنظر لنا بعينيها الواسعتين الغامقتين. كما لو حثث معجزة ما بعد تلك النظرة: صوت كلمة، حتى وإن كانت منطوقة بشكل غير صحيح أو صوت مقطع مزفور من نفاذ الصبر أو ثائرة الغضب. لم تحدث قط مثل تلك الأعجوبة أو المعجزة الصغيرة، لكن عشية عيد الميلاد لسنة 1954، ركضت اناستاسيا سوكوهو للمطبخ وهي تصرخ "قد تعلمت الطقلة فعلاً الكتابة"، وتقريباً الجميع هرول للحديقة: أبناء اميلي الثلاثة والجيران وصديقاتها وشقيقها اميليو، وفي مقدمهم جميعاً سمارة ديليا، التي كانت تواظب على إقامة التساعيات 23 وعلى قراءة الصحف من الجلدة للجلدة على أمل أن تعثر على اكتثاف علاج يعيد لابنتها الحاستين المفقودتين. بعد ذلك وصلت اميلي، و افسح الجميع لها لكي ترى ثريا أنجيلا جالسة بين الزنابق البيضاء، وبيدها اليسرى طباثير أحمر تخربش به على درقة السلحفاة "سلوى" آخر حرف من اسم مألوف جداً.

كانت هذه أفضل هاية لعيد الميلاد - بعد ذلك اصابت اميلي الدهثة عندما نطقت حروف اسمها، وعيناها تحملقان في درقة السلحفاة. حينئذ تهلات سمارة ديليا، لأنه لأول مرة اشقاؤها يرون ثريا إنساناً، لا وحثاً.

وبعد وفاة ابنتها بسنوات عديدة، في محادثة بينتا قبل أن أغادر ماناوس، الخالة سمارة ذكرت لي أنها ندمت لأنها كانت سعيدة في تلك اللحظة.

وفضفضت قائلة: كنت لازلت ساذجة. اعتقدت أن أخوتي كانوا قد غفروا لي أنني ولات ابنتي، لكن كل ذلك لم يكن إلا مجرد تمثيلية لكسب تعاطف أمي؛ ظنت اميلي أنهم اذابوا جليد قلوبهم معي، لكنهم كانوا يحيوني فقط أمامها، ويتوددون إلى ثريا المسكينة، ويتظاهرون بالاحترام لوالدي، لأنهم كانوا يحتاجون لمفتاح البيت ولبعض المال لحفلاتهم؛ وذكرت ذلك لوالاتي، فهل تعرف ماذا أجابتتي؟ وُلِدَت ابنتك صماء بكماء، وأنت لا تثعرين بهم؛ فإخوانك يحبونك، وأحياناً لا يفهمونك لأنهم لا زالوا صغاراً: المراهقة سن التمرد. 
واصلت الخالة سمارة قولها: ـ نعم، كانوا مراهقين ووقحين. - في اليوم الذي توفت فيه ابنتي كانت قد واتتهم الجرأة على

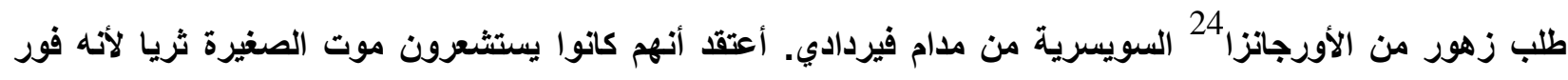

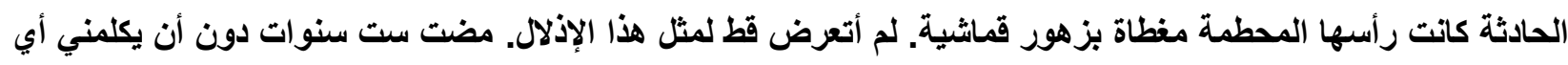

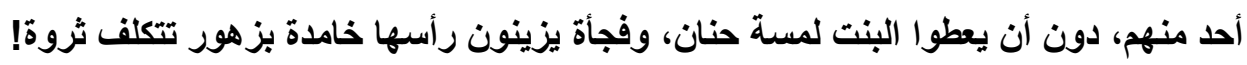

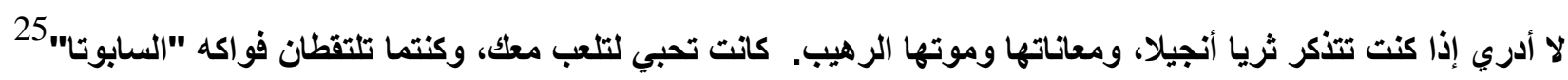

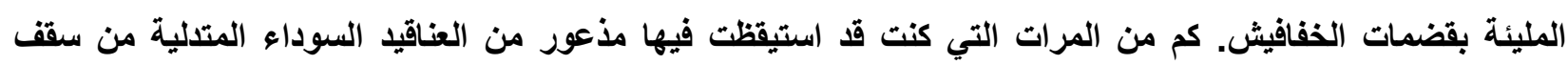

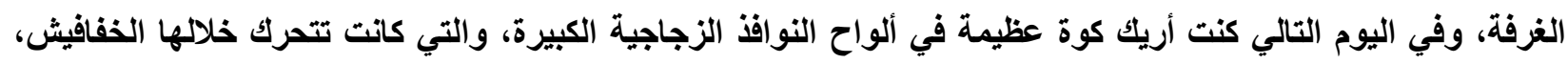

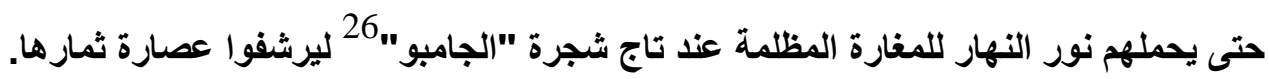

كنت غائباً في ذلك الصباح. كانت اميلي قد أختلك للسوق، كانوا الأخوال نائمين، وبكرت سمارة ديليا مع جدها إلى دوَّار

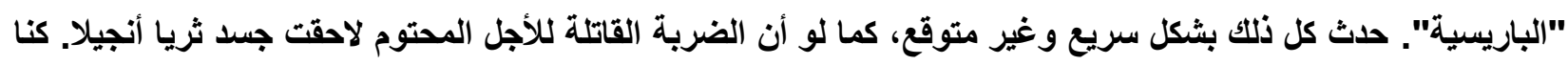

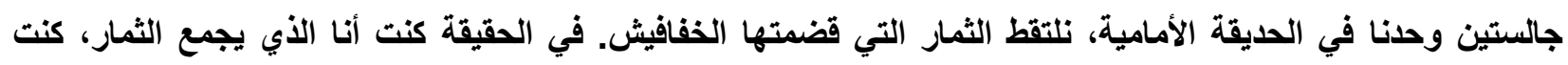
أقطف الخثخاش وثمار شجرة الجامبو، وأضعها كلها في سلة؛ في بعض الأحيان، كانت ثريا تساعدني وكانت مثيرة للانتباه

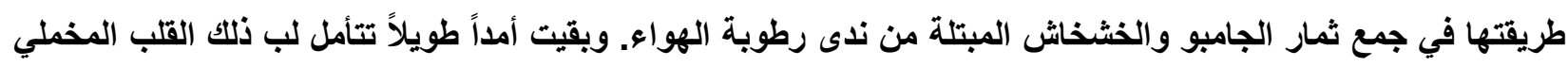

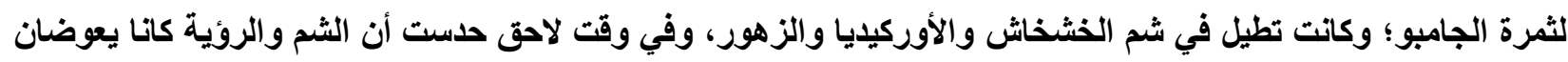
إلى حد ما غياب الحاستين. في أحيان أخرى، كما في ذلك الصباح، تلعب بدمية قماشية صنعتها اميلي لها. أتذكر تماماً

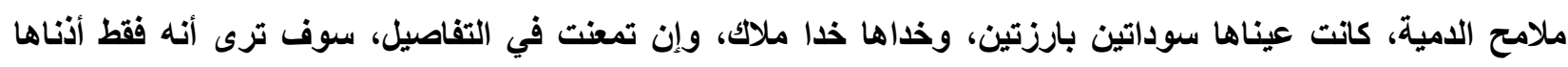

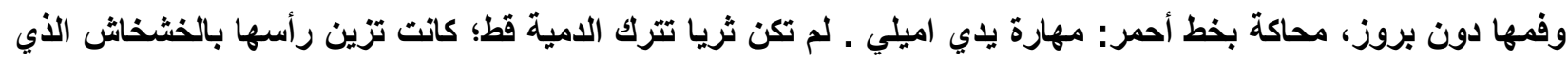

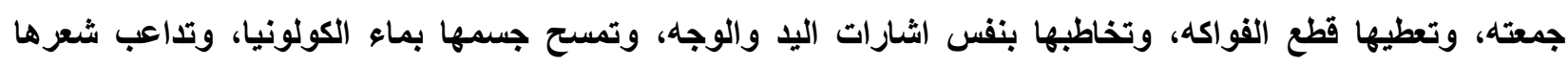

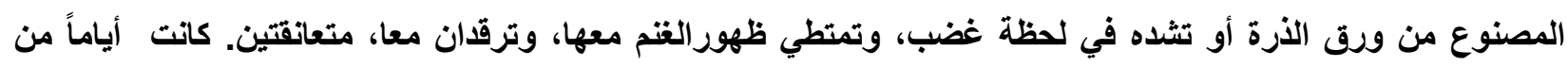

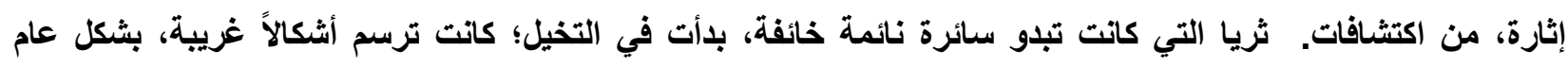

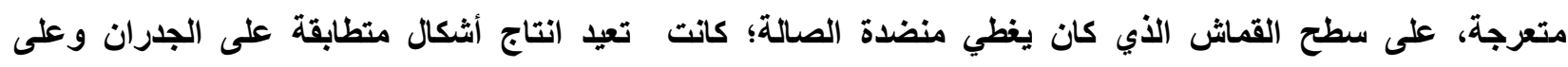
الفسيفساء المجعد الذي كان يحدق بالنافورة، وعلى درقة سلوى حيث اسم اميلي لم ينمح حتى الآن ـ وحكت الخالة سمارة ـ

24الأورجانزا نوع من قماش خفيف ناعم.

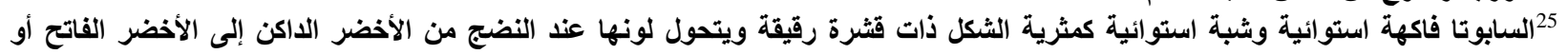

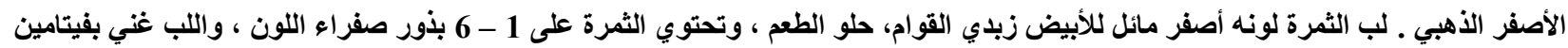

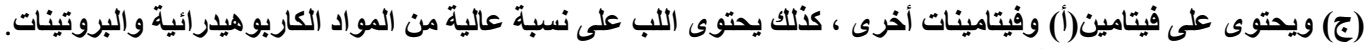

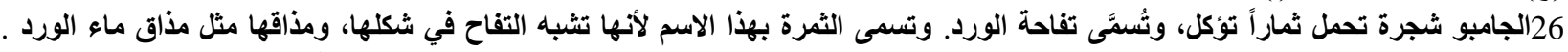

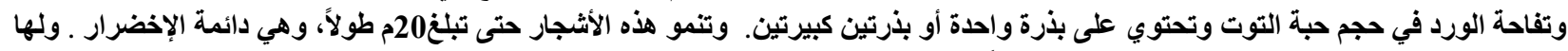

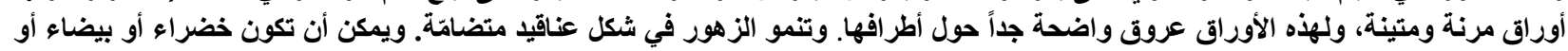
حمراء أو صفراء باهتّة. وتتظذى القردة والسناجب والطيور وخفافيش الفو اكه بتفاح الورد. 
في إثارة واحدة من إثاراتها القليلة لابنتها- أنها ضبطتها في إحدى الليالي متلبسة أمام مرآة فينيسيا بالغرفة، ترسم شفتي الامية وخديها؛ ترى الواحدة منها الأخرى، وكانت المرآة تسهم في عزلهما عن العالم. افثتت بصوت مرير كان يمكن أن يعبر كنلك عن معاناة اميلي :عندما رايتها هكذا، منهمكة للغاية، عدت مثياً على أطراف

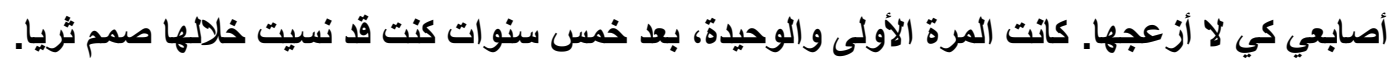

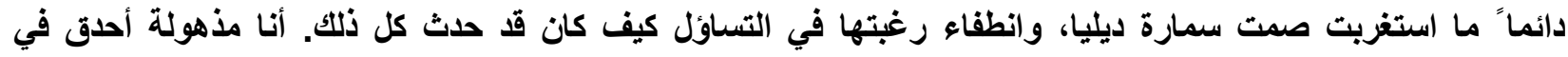
الثشارع، وتلك اللطمة المكتومة التي بلت تطفو على البخار المنبعث من الأحجار الرمادية. كنت أبحث عن ثريا من حولي،

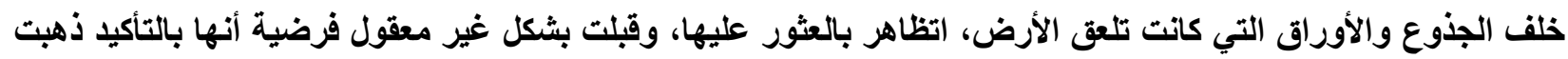
للفناء لروية الحيوانات، والاستحمام في النافورة، والقفز على سياج حظيرة الاجاج، والاماءة بشراسة أمام قن الاجاج، لتصير الطيور في حالة ذعرٍ من النوم للتدافع الفوضوى، وتطلق أجنحتها وتنقر الأرض والهواء، وتتنازع، محاصرة بين الحاجز الأي لا يمكن تجاوزه، والثكل الرهيف مع التواءاتها الزائدة لا يهادها؛ لكن ذلك التمثيل الصباحي الذي حضرناه كلنا برهبة وشفقة، ربما كان حفلاً لثريا، وسيلة لتكون مسموعة أو مرئية دون القدرة على الكلام، جملة اعتراضية في حياتها اليومية (حظيرة الاجاج وفناء البيت والحيوانات)، للهروب من النظرات ومن همسات الاقرار: إنها لا تتكلم ولا تسمع، ينحسر جسدها إلى دوامة إثارات، وسط مشهـ تبصره عيون راضية.

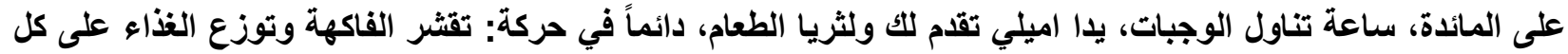
واحد منكما ، لكن أنت كان يمكنك بالفعل أن ترفض أو أن تقبل الطعام بكلمات قصيرة، بكلمات أحادية المقطع، في حين ثريا كانت ترتضي بابعاد الطبق، والتظاهر بالرفض برأسها أو تنحني نحو الطبق، وفي بعض الأحيان تنظر للك، ولفمك، ريما تفكر: "متى غابت عني الكلمات؟ " أو تفكر: "في أية لحظة اكتثفت أنني لا يمكني أن أتحدث؟ "، ربما خجلانة لأنك مع بع الاهي صغر سنك كنتي قادرة بالفعل على بناء جمل غير تامة، صحيح أنها كانت متقطعة ومفككة، لكنك بحركة شفتيك، كان أحد

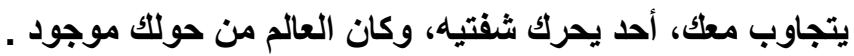
رأيت الكثير من الناس تهرول من الثارع، من بوابة الثكنة، من الميدان، من المنازل المجاورة، في اتجاه الصدمة، وفيما بينهم، اميلي تمكك بيدك، عيناها تريدان أن تجاني؛ لبثت منكمشة دقيقة واحدة تحت كأس شجرة الجامبو، حتى قررت الجري دون النظر إلى الوراء وصعدت الارجات بحثاً عن أي أحد. هناك في الجزء الطوي بدا كل شيء هادئاً وغافلاً عما

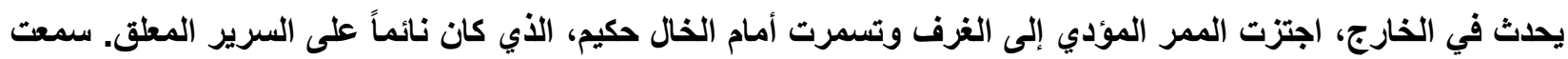
أنفاسه المتناغمة، احست بالحرج أو الخوف من ايقاظه، لمحت في العتمة كومة هائلة من الكتب، وهي نفس الكتب كما هو الحال دائماً، التي قرأها وأعاد قرائتها عدة مرات؛ كنت تجلس على هذه الدعامة الورقية، في حين كان الخال حكيم يتصفح أحل الكتب، يستعرض حفر يوضح جريمة وشيكة، مشهد حب، وفاة بطل كنت تتهجى اسمه المعقد بتأتأة حلقية؛ عند سماعه نطقك اسماء سلافية، كان حكيم يسخر من الجميع، وحتى من نفسه، عند تأكيده أن النطق الصحيح لاسماء تلك الثخصيات يمكن أن يأتي فقط من فم طقل عنده سنتان أو من فم ثريا. من الأخوال الثلاث كان الوحيد المعتاد على التهريج

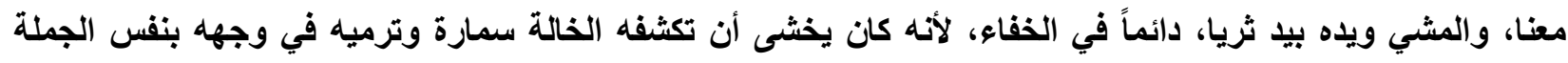
المكررة منذ أن ولات ابنتها: "لا أحل منكم يستحق لمس ابنتي". لكن لم يكن يشعر بالرهبة من تحذير شقيقته، رغم أنه كان يعرف أن لايها أسبابها لمنع أي اتصال لابنتها بأثقائها. لكن الخالة سمارة كانت تثثك أنه في الأثشهر السابقة لعيد الميلاد ل 
54، بدأت ثريا تمشي في المدينة برفقة الخال حكيم. ساعة الغذاء، حينما كان الجميع حاضرين، كان حكيم و سمارة صامتين

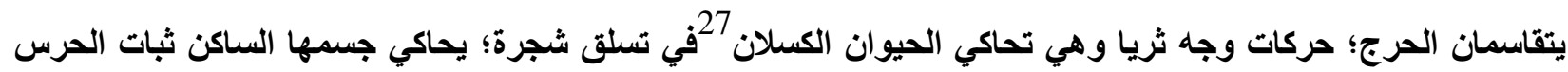
البرونز الموجود أمام الثكنة، وتستدعي الحركات التي كاتت تقوم بها بيديها وذراعيها حوار الثقيقين الصقليين مع كلب،

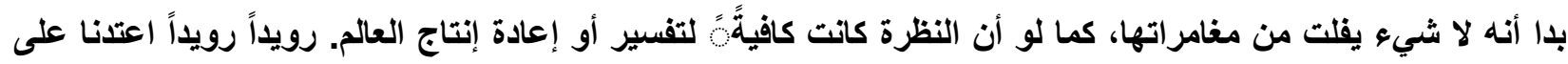
حكيها ما كان يحدث في شوارع الددينة؛ كاتت ثريا تحضر للبيت بلفتات صارخة باقة متنوعة من الأحاث: كاريكاترات

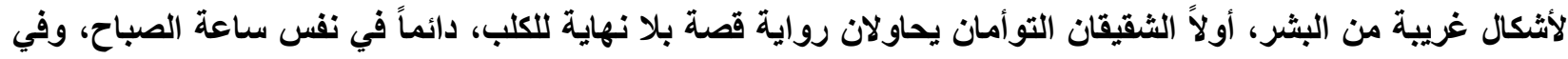

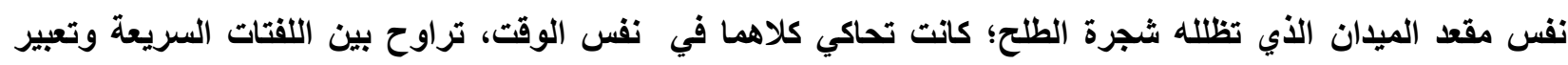
مفاجئ من الاهتمام وعدم الفهم، العيون شبه واسعة واليدان متكتئان على الأرض؛ في الأول الثقيقان التوأمان مع الكلب،

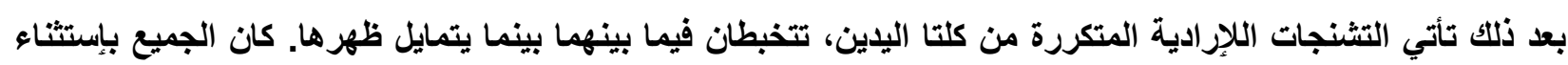

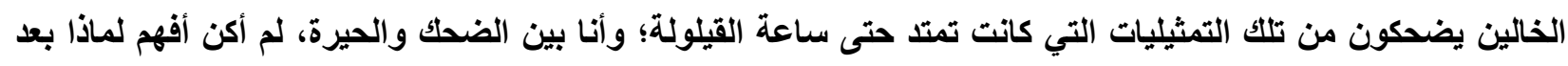

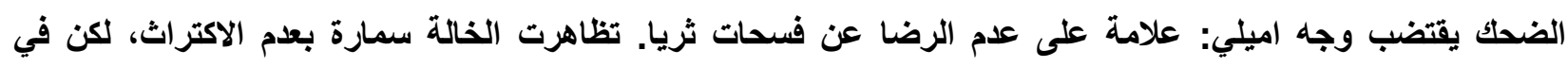

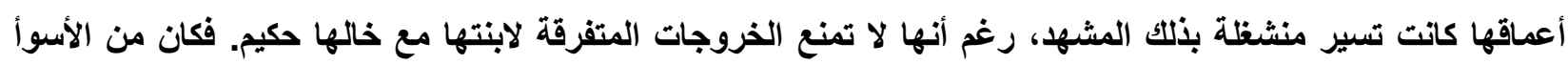
رؤيتها تكبر داخل حدود البيت، تقتفي آثار الفواكه والخشخاش، وتلسع يديها عند التهات حفر أعثاش النمل.

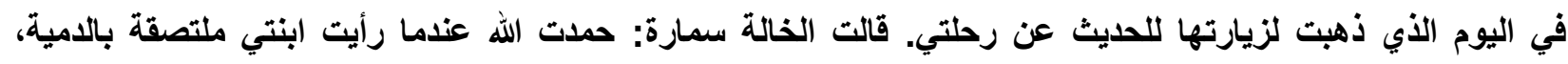

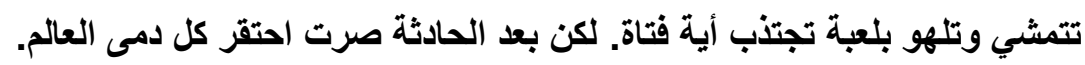
كانت لا زالت تعيش وتعمل في دوًار "الباريسية"، وكاتت ماهرة في فنون التجارة لارجة أن جدنا خصها للأبد بمهمة

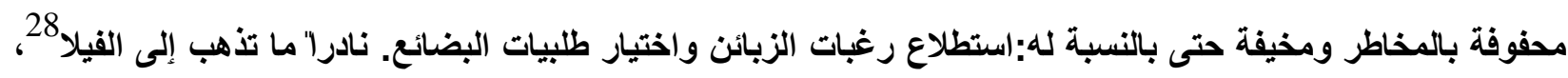

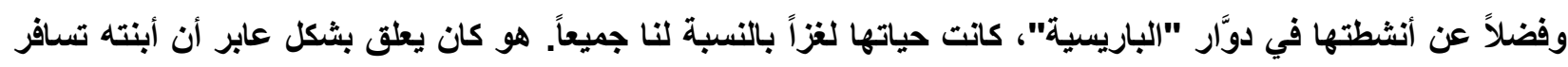

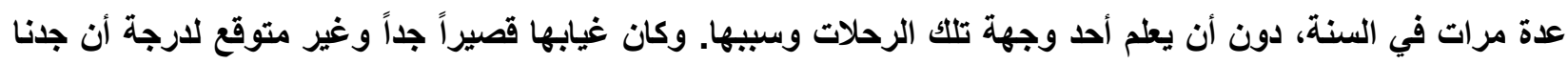
كان يبلغنا فقط أثناء تناول الذذاء: قد رجعت سمارة. وفي أحد الأيام، وبعد نظق العبارة المقتضبة ، أضاف أحد أبنائه:

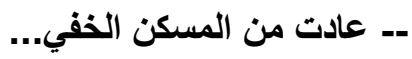
في تلك الفترة لم يكن لجدنا أي دافع للرد على هذا أو ذالك، ناهيك عن توبيخ الابنين اللانين وصفهما في الماضي بالتخاذل،

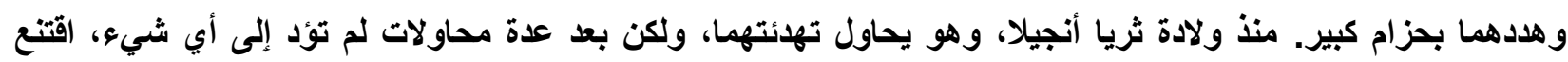

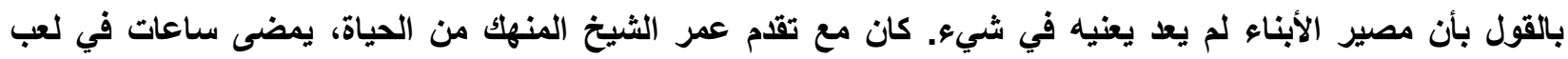

(bicho preguiça) ${ }^{27}$

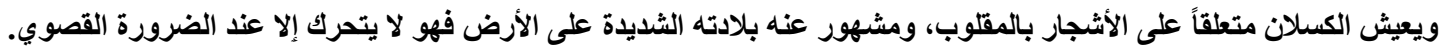

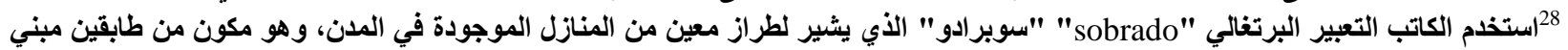

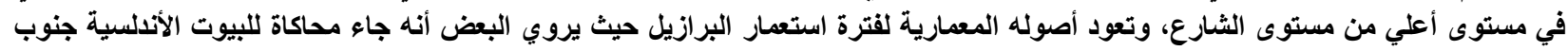

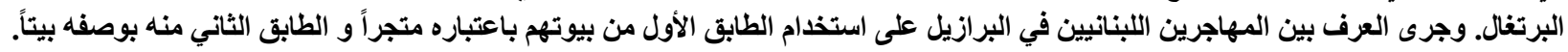


الطاولة وسرد الحكايات لك، وعمل بصدق مذهل على مديح ابنته لارجة أنه أربك اميلي في آرائها حول الحالة العقلية لزوجها:

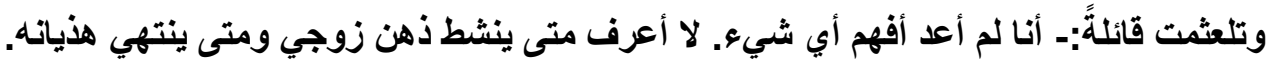

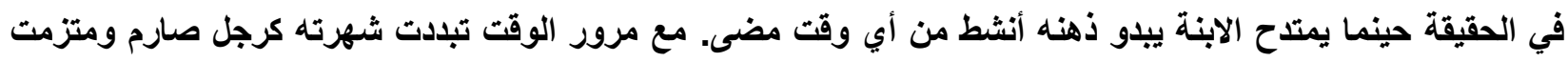
وموسوس، ومن التعليقات العابرة عن شخصيته، ييقى الإجماع على أنه قبل أي شيء كان شخصاً سخياً يعثق العزلة. كان النهان

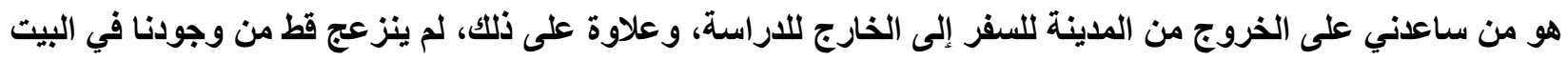

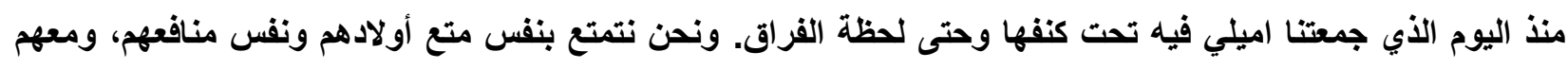
عانينا من أعاصير غضب أب ياتس وأم تعيسة. لا شيء ولا أحد يستقصينا من الأسرة، لكن في اللحظة المناسبة يعنى بتوضيح من نحن ومن أين جننا، وحكى كل شيء بكلمات قليلة تخلو من الثفقة و من الأسى. الوقت القصير الذي أمضيناه فيه معاً، أعربت الخالة سمارة عن أسفها لغياب شقيقها حكيم. وبقدر من الاستياء،كاتت تقول: "مضى ما يقرب من عشر سنوات منذ أن رحل، ولم يكتب لي خط واحد". أحداث الماضي لم تعد تضايقها كثيراً؛ لذلك ربما

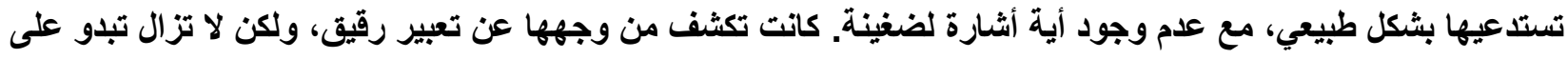
جسدها علامات الحداد نفسها: ثوب من نسيج، كله أسود، قبعة دانتيل أسود تربط شعرها الأسود وعقد لؤلئو أسود يخص

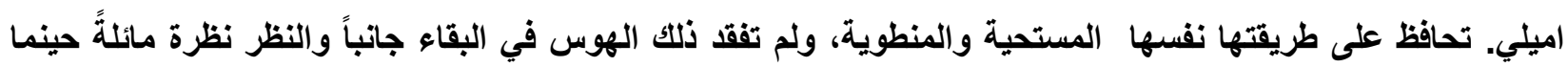
تتحدث. تتذكر ابنتها بين الحين والآخر: شيطان وسيم، بشع فاتح ومجعد وجسم صغير رهيف، مثل جسم غزالة. أستيقظ في الصباح تواقة لتأمل صورتها، كمن

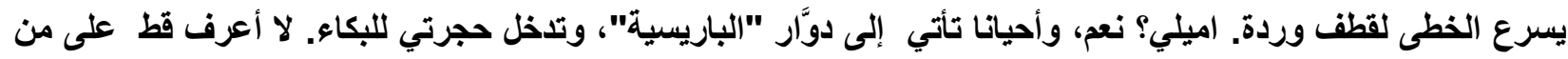

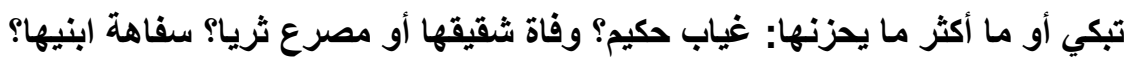
تطلعت لي بوجهها المائل جانباً وقالت:

- هل تعرف أنني لم احتج لهم قط، لكن اميلي كيف يمكنني أن أعيش بدونها؟ لا أحد يمكنه أن يعيش بعيداً عن اميلي ولا أن ينتقا عاداتها.فمثلاً، نجت الدمية من الحادثة ويقت محفوظة بين متعلقات التهات اميلي، التى نهت ابنتها عن حرق اللعبة. كان الخال حكيم هو من أخذ الامية من يدي الأطفال، وبعد الحادثة بوقت قصير. أنا ايقظته بهز السرير المعلق، وبذعر سقطت على الأرض النظارة التي كانت على جبهته. يترنح من النعاس ويعانى من تفتيح رموشه الملتصقة. أعتقل أنه كان لا يزال يستمتع بصور طلم فريد من نوعله، فقد ابتسم في وجهي وتنهـ "يا جمالكا!"،

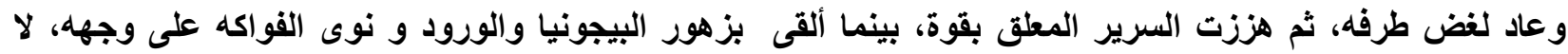

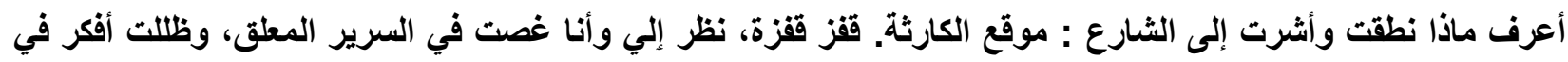
الوهج المترامي في وسط الثارع، قلقة عليك، أبحث عنك، لكنتي كنت قد لمحت فقط اميلي منحنية على جسم تفطيه ملائة

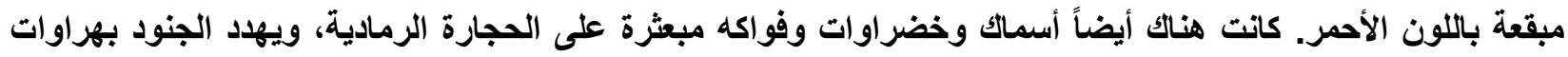
الأطفال الذين يحاولون سرقة مشتريات سلة اميلي المتناثرة على الأرض بجوار جثة بنت الخالة، كان الأطفال الهنود يقفزون فوق بقعة الام، يرغبون في لفت انتباه الرجال المسلحين الذين يرتدون الجينز أو الزي الكاكي، درجة لون بشرة 
تحت نور الثمس الثديد بال الجميع من البرونز، يتناقضون فقط مع زهور تنورة إميلي، والبقعة الحمراء التي لا تزال

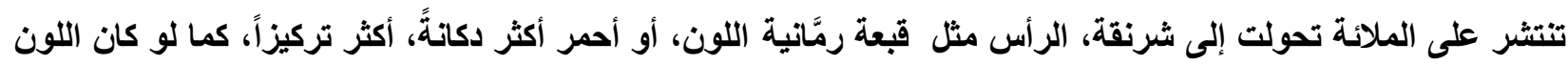

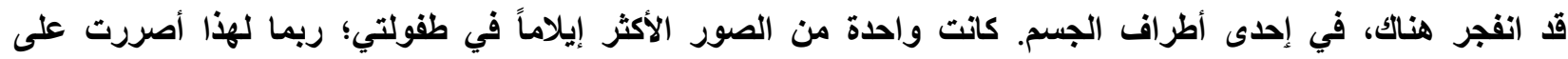
إستدعائها في خطابين أو ثلاثة كتبتهم للك؛ في ردك كنت تدعوني بالمحظوظة، لأن هذه الأحداث قد وقعت عندما أنا كنت أقدر سواء بثكل جيد أوسيء على تثبيتها في ذاكرتي. في إحلى الرسائل التي أرسلتها لي، كتب شيئا" مثل: "الحياة تبدأ فعلاً مع الذاكرة، وفي ذلك الصباح المشمس والمشؤوم، أنت تتذكرين تماماً الأساور الذهبية الأربعة على ذراع اميلي الأيمن

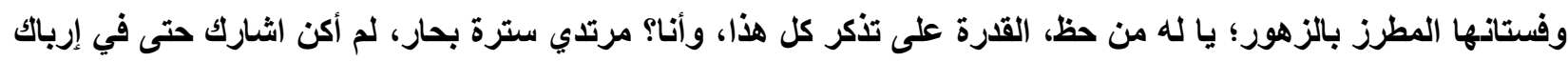

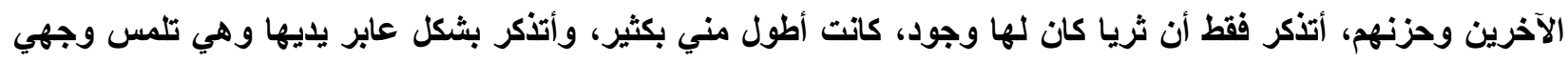

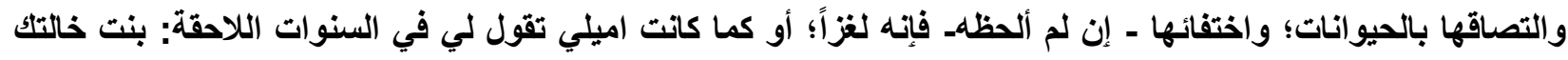

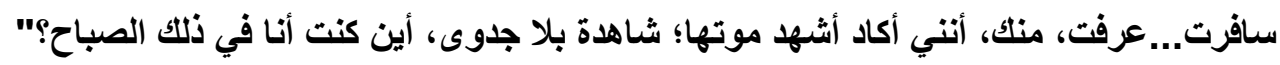

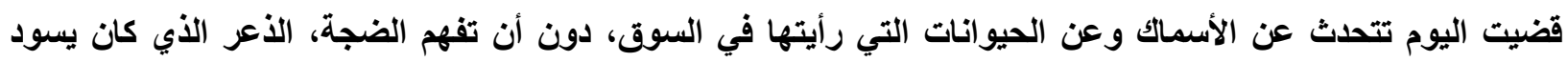

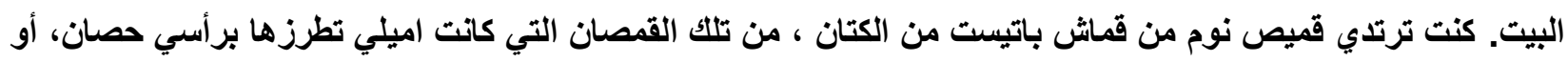

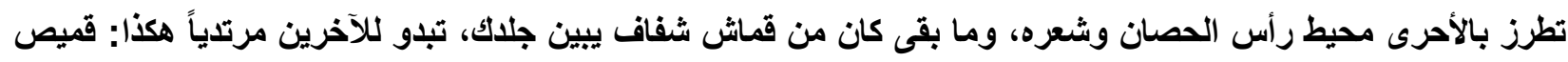
نوم مطرز ساقطاً حتى ركبتيك، وكنت تحتني حذاء بوت عسكري وجورب من القطن ينتهى أيضاً عند الركبة، وعليه

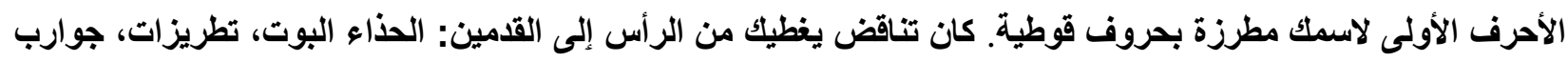
طويلة، مبالغات اميلي، التي كانت تجلكك على مقعد مرتفع، وساقيك في الهواء، وشعرت بنوع من الاوار لأنك نظرت الإنى الأرض كأنها هوة وهناك في العلو مكثت بلا حركة: تمثال أو لعبة للبالغين الذين يتأملونك، يتفحصون خديك وملامحك، والجزء اليسير المرئي من جسمك في ذلك العرش المقام بعناية تحت كرمة الفناء الأصغر، كان السقف النباتي يحميك من فئ

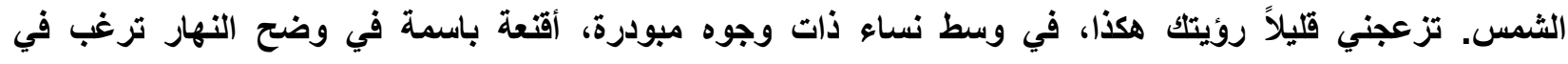
ابتلاعك،ثتير كل إنشارة منك صراخاً و تثنجاً، يقبضن جميعهن على المراوح اليدوية، وتتنافسن على مكانٍ بجانبك، لتهوية معبود اميلي الصغير. كانت إميلي فرحانة خلال تلك الجلسة الوثنية، ويروق لها أن تلحظ موقفها كأم الانيا، تمتد فوقلك مثل فقاعة مشعة منتفخة

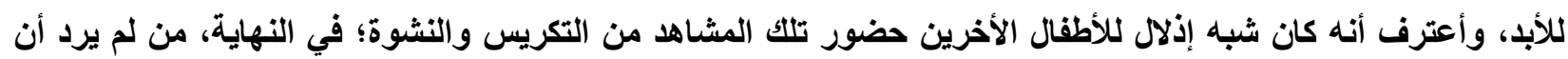

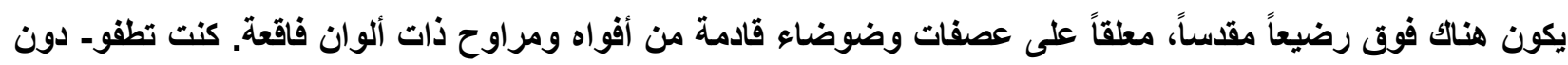

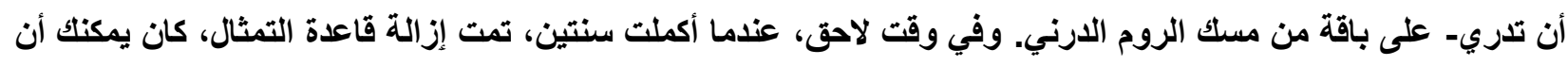
تثبت على الأرض وأن تمشي وحلك، لكن ظلات محاطاً بسور من النساء، تفوح بروائح غريبة مثل أسمائها: مينطه، هندية،

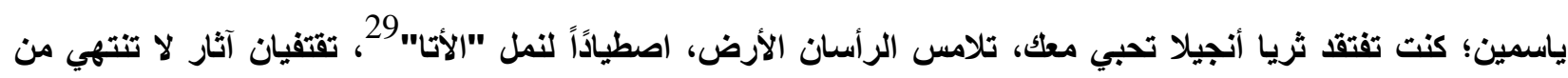

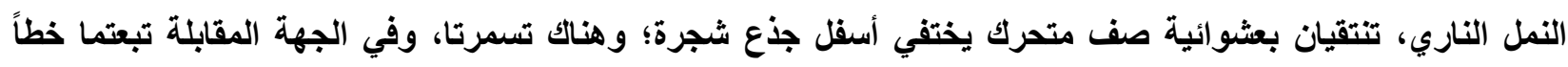

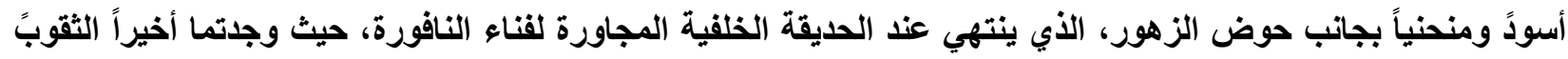


التي يجيء منها ويذهب إليها: مساكن تحت الأرض، متاهات لا يمكن رؤيتها، تلال متحركة، تتزايد، تختفي هنا وهناك وتعاود النهوض. كنتما تعرفان بالفعل أن نتوئات الأرض والعيون الثابتة على الأرض تحرق مثل النار؛ كانت بالنسبة للك جبالاً وحدقات خطيرة، لكن ثريا كاتت تستمتع بتحديها بأصابعها وبيليها وبوجهها، وقد جاعت ذات مرة تفرك وجوهها في إحدى تلك النتوعات البركانية، ثم خرجت مندفعةً نحو النافورة؛ ومن وجهها بلت أن تبصث نيراناً، وتركز كل معاناة صوتها غيرالموجود في معالم وجهها، في عينيها المغفضتين، في يديها اللتين تتلمسان حواف صدفة حجرية ضخمة تبحث عن شيئاً، من سائلٍ لتخفيف آلامها، وطفرات الماء من الفم الحجري للملائكة؛ تعانى من غياب ثريا، وحيدً بين قلاع وكهوف نارية، غير محمياً بظل جسدها، كنت تجهش بالبكاء، دون أن تنظر أولاً للنافورة، وجه ثريا المنتفخ، الضحك الذي كان ييزغ من شرائح المياه وخصلات الثُع. كما لو كان انعكاساً للعذاب والألم، واحد يبكي لغياب ما، وآخر يضحك عند التحقق من سبب البكاء. كنت تصمت عندما تعود هي من النافورة وتحمل بين كفيها ماءًً لتسكبه على جسمك، تجذبك لفسيفساء الفناء، للنافورة، تقودك للصخرة البنية والبارزة، التي تتظاهر بالسبات عبر القرون؛ تلك المنحوتة الغريبة، في بعض الأحيان تصبح بالقرب من النافورة وتختلط بالمادة السميكة والخثنة للنافورة نفسها؛ في وقت آخر من اليوم كان بلا جدوى البحث عنها، وكم من المرات قلبت المزرعة و الممر الجانبي و الأفنية دون أية نتيجة؛ كنت محبطة لأنني لم أجد مخبأ حيوان بطيء جداً، لكن ذللك البطيء، الأي يصحبه خلال أكثر من قرن من الحياة والأي يبلو لنا تحدي أو مواجهة، يعد جزء من طبيعة الحيوان نفسها؛ كان يرعبني عند العثور عليه دون قصد، مموهاً تحت كومة من الأوراق على الأرض؛ بلا أكثر ولا أقل كان الثيء يبان من الحركة قبل أن يظهر من تباين الأنسجة، خلافاً لغيره من حيوانات أخرى تفتقر لارقة، كما لو كان قد تعرض حتماً للزمن، للخارج، للعالم. من خلال الثيش كنت اتجسس عليكما من عند الساعة الكبيرة السوداء، تلك العلبة بمؤشر اتها الذهبية التي عبرت تقريباً قرناً كاملاً لتنافس أميلي في الدورة المتكررة للأيام؛ تلك الساعة الحائط، الأصمت من كل الساعات التي عرفتها، كاتت من أكثر الأشياء التي فتت ثريا. كانت تجلس ساعاتً أمامها، وتثبت عيناها على الحركة البندولية للمؤشر الذهب،، على عقرب الدقائق، تنتظر القفزة المنتظمة وكذلك الصامتة للسهم الأسود. اليوم أظل أفكر في الوقت الذي كانت تكرسد لذلك الحوار الصامت مع الزمن، غير مبالية بالضربات التي تصدر حينما يلتقيا السهمان، ويكفي أن أقول أنه في منتصف النهار كاتت الضربات الخثنة والحادة تؤلم سمعي، وأنا كنت أبعد عن المصدر الصوتي. بل ولا أحد كان يتحمل الضربات التي كاتت تلق فجأة مثل الرعد. منذ صغري، كنت أرى ثريا غير متأثرة بالثيء الأسود الذي يعلن منتصف النهار؛ في البداية تخيلت أنها قد تكون مزحة، لكنها لم تزغ البصر حتى عندما تقترب اميلي من الساعة عند منتصف النهار، كاتت كل يوم منفمسة في جو صدى الصوت لا غير، كانت تفتح الغطاء الكريستالي، تبحث عن شيء ما في إحدى زوايا الصندوق، وتتلمس جدرانها الداخلية لتسحب مفتاح، ومن ثم كاتت يدها تتوه في الأحشاء المعدنية، تبحث عن الثقب، الفتحة التي تناسب المفتاح، هنالك، في قلب قلب الماكينة. من الأثياء الموجودة داخل البيت، الساعة الكبيرة كاتت الوحيدة التي تعبدها ثريا أنجيلا. قال الخال حكيم ـ الأي يظل يحكي قصص" غريبة" عن هذه الساعةـ أن الأمر انتهى بها أن تم تعليقها على حائط الصالة، بعد شهور من التفاوض بين اميلي ومرسيلي كان قد باع دوَّار"الباريسية" للعائلة، هناك في الثلاثينيات. كادت الصفقة أن فشلت بسبب تعنت كلاهما، ويبدو أن جدي وصل به الأمر أن واجه اميلي بأنها قد تخسر كل شيء بسبب ساعة. قال العجوز: - نتعرض لخطر الاضطرار إلى العودة لأرضنا فارغي الأيدي. 
ردت اميلي: - لا بأس، عندي في لبنان الساعة التي أحبها، وعلاوة على ذلك لن أحتاج إلى التلعثم أو استثارة القواميس

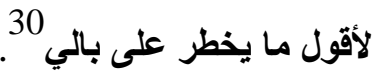

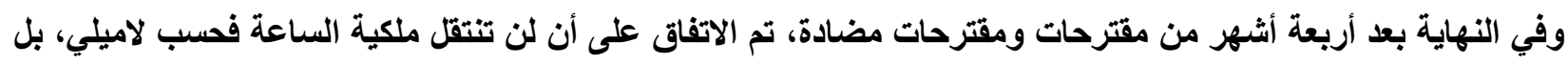

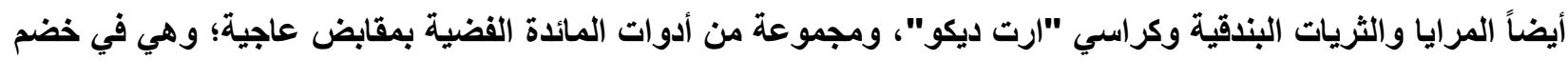

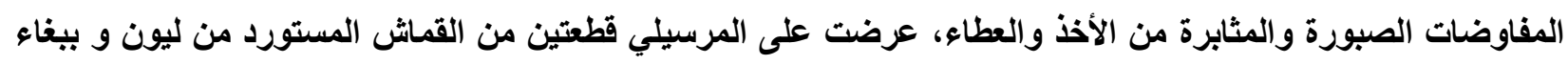
أنثى موهوبة بلهجة مميزة من منطقة البيريني الوسطى وقادرةعلى نطق "Marseille" و "La France" و" Soyez le 31"bien venu

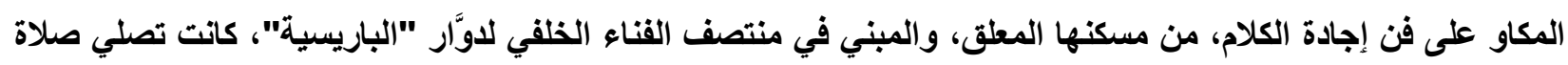

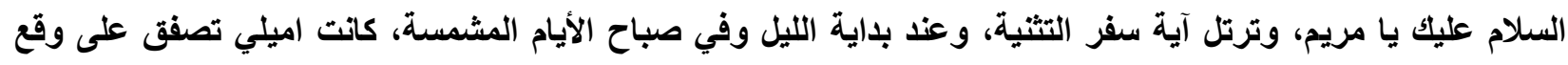

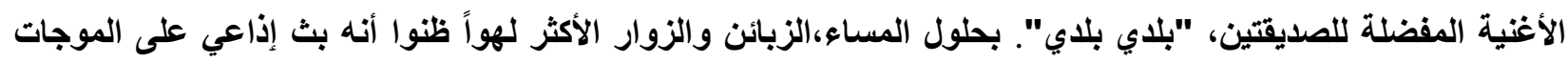

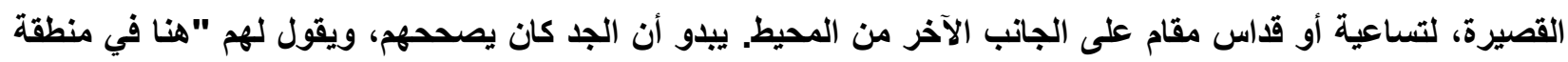

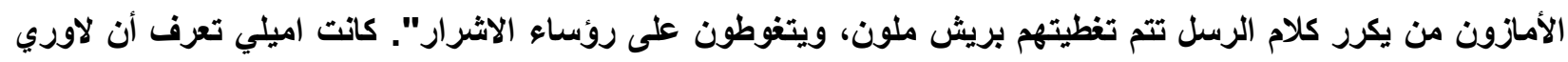

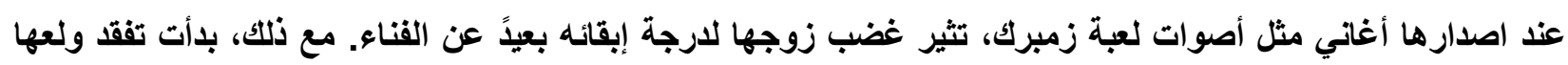

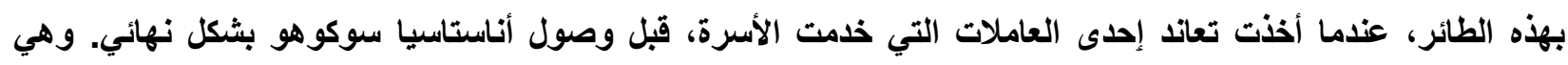

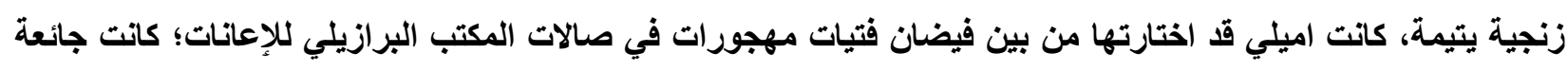

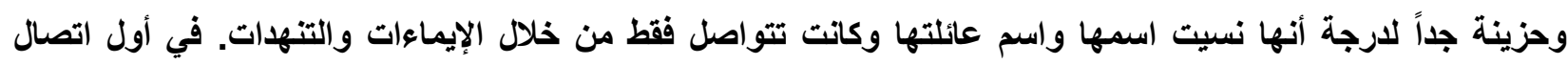

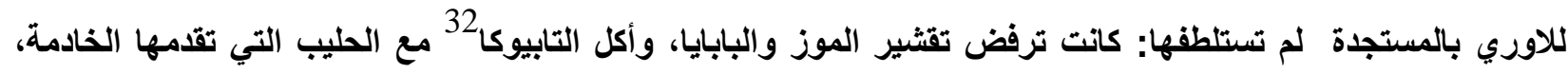

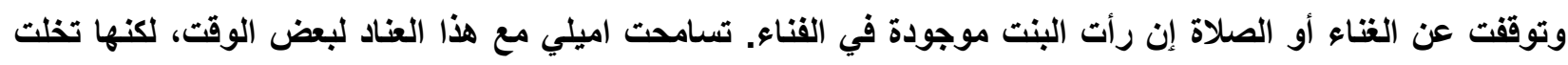

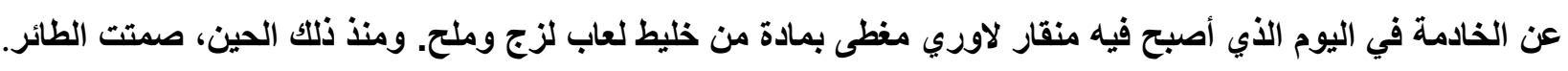

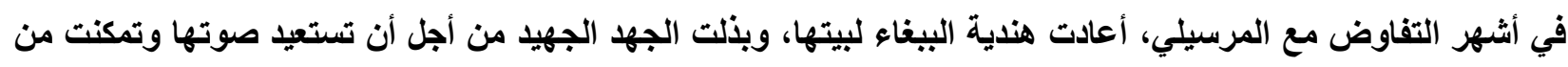

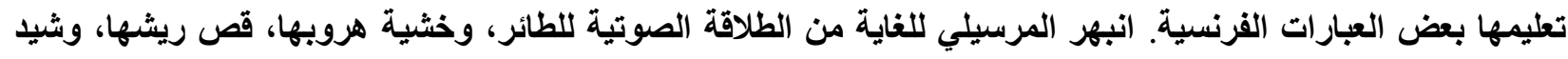

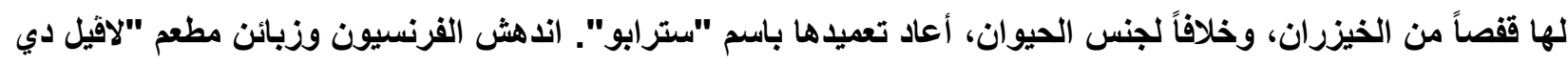

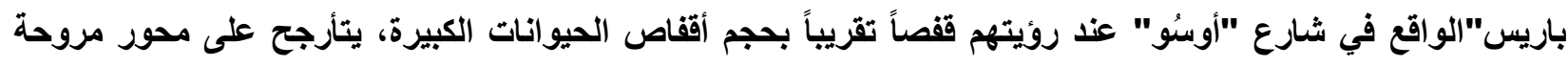

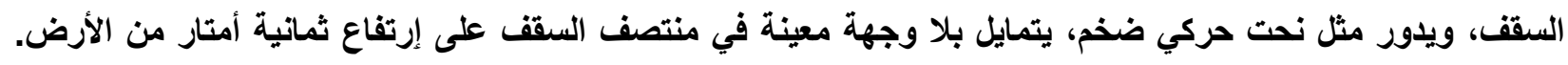

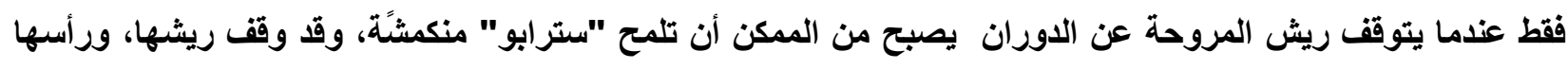

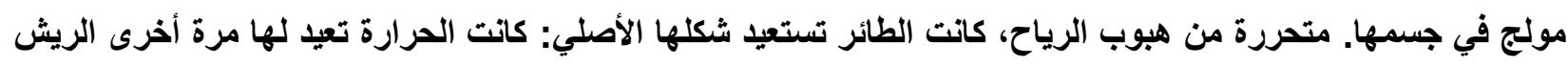
القزحي اللون وأسلوبها المتباهي، وصوت هنئ نقيقها يردد آخر عبارة تغلمتها:

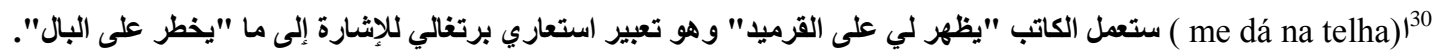

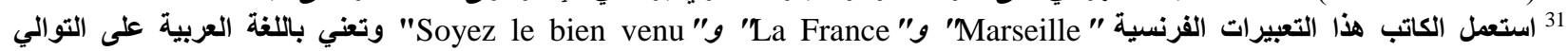

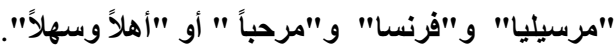
(tapioco) 32 
"Je vais à Marseille, pas toi ${ }^{33}$ " البعض يضحك دون فهم، والبعض الآخر يشعر بالحزن لأن الميناء الذي كان "سترابو" يقصده كان مستحيلاً عليهم،

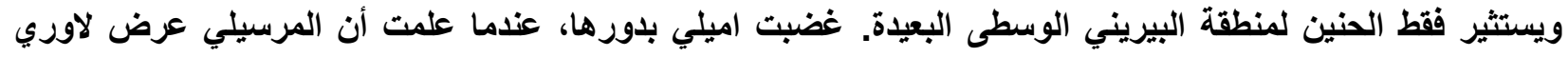

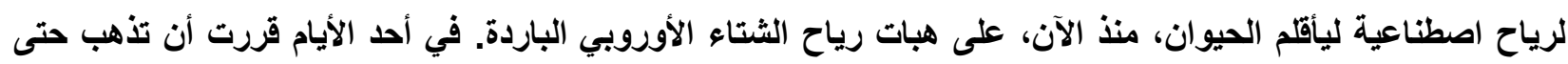

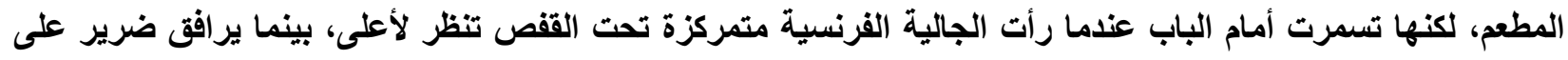

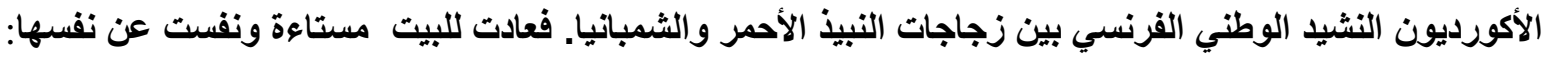
مع ديوك كثيرة طليقة هناك قرروا أن يجطوا من البيغاء رمزاً للوطن. فقط ينقص تحويل حيواني الأليف إلى ببغاء ثلاثي الألوان. بالنسبة لجدي، بالنسبة لنا جميعاً ، ظل الاقتناء العلح للساعة لغزاً لفترة طويلة. لو كان هناك شيئاً متماثلاً بين ماناوس

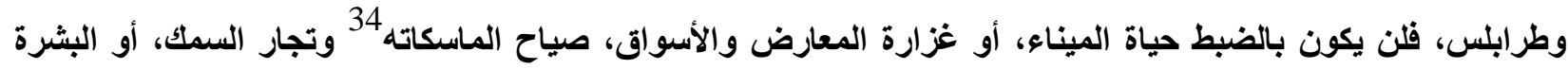

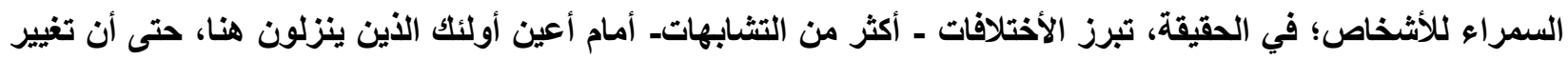

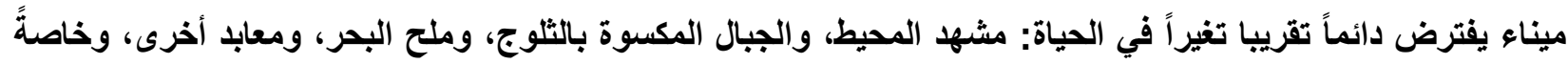

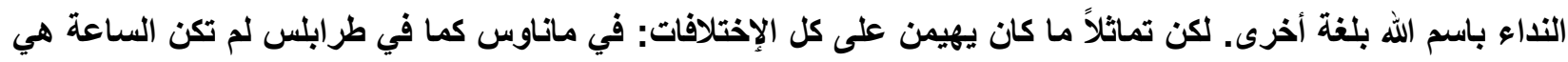
التي تدفع الحركات الأولى لليوم ولا تحدد نهايته: ضوء الثمس، وتغريد الطيور، وأصوات الناس التي كانت تلخل الركن

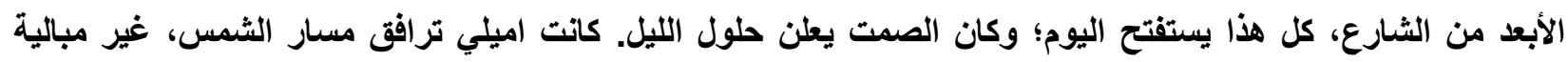

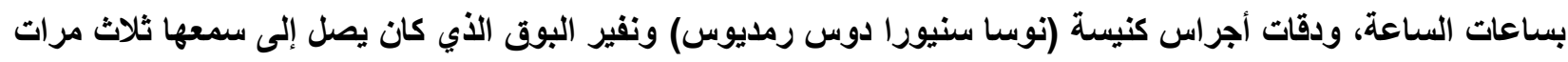

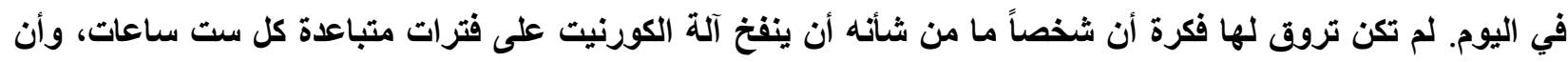

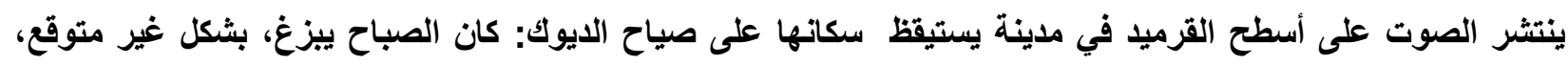

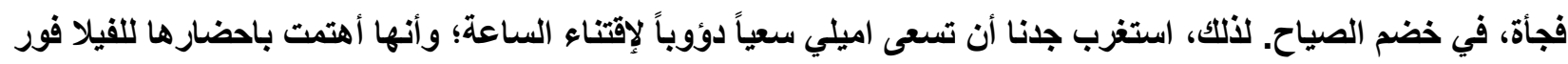
افتتاحه؛ وَجِيء بالمر ايا والأثاث في وقت لاحق، عندما صار دوَّار "الباريسية" مجرد مكان للعمل.

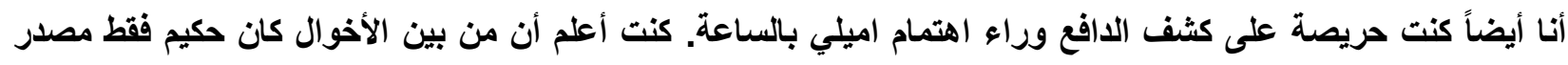

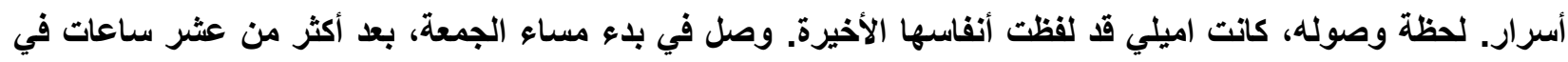

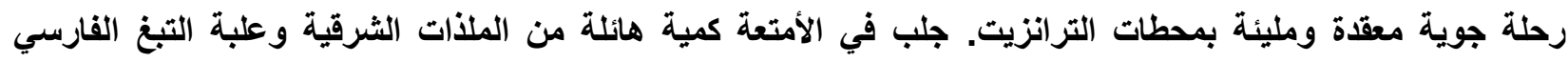

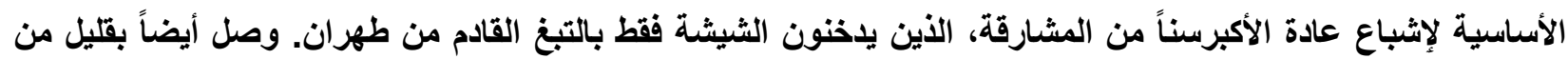
الأمل، فالخال اميليو - متحفظاً ومهذباً. تجنب قول الحقيقة لابن اخته. نبه بالتليفون أن اميلي أكثر حزناً وحنيناً منها كونها لأنها

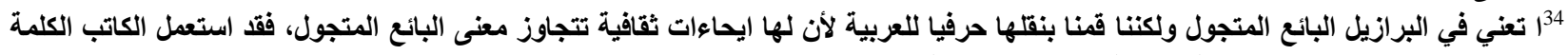

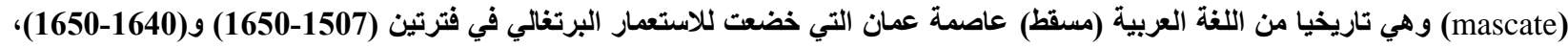

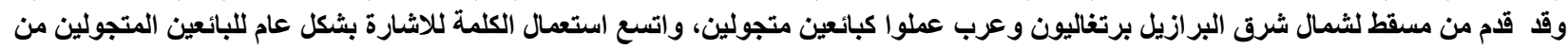

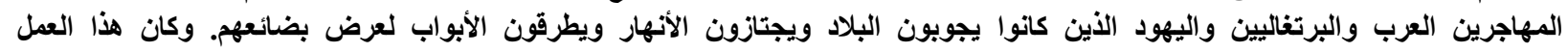
(mascateação) اشتقوا من الكلمة فعلا عربيا يستعملونه (mascatear). 
شائخة، وترجى حضوره قبل غروب شمس تلك الجمعة. وافق الخال حكيم دون إلحاح على التحدث مع اميلي، مع علمه أن الأم كانت شبه صماء، وكانت تنصت فقط لأصوات شخصين أو ثلاثة بالإضافة إلى هندية كونسيساو، ورغم ذلك كان من الضروري أن تتحدث صارخةً، ببطء شديد وبالعربية. عندما عدنا من المدافن في بداية المساء، نحن وجدناه بمفرده في الحديقة المهجورة في البيت الكبير المظلق. كان يلاحظ من خلال الجدائل الخشبية داخل الصالة حالة فوضى، غير راضٍ عن

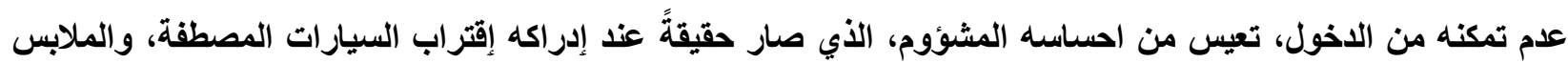
الداكنة للنساء اللواتي نزلن لتحيته. لحظت طريقته المحرجة، ويديه المفتوحة التي تهاب شعره الرمادي، وحركاته المتسارعة لضبط جسمه وتوضيب سترته الكتانية. والتعبير الحائر لوجهه، لأن تحياته التي كانت غامرة وحارة لغيابه فترة طويلة، لم تتجاوز المصافحة أوعناق التعزية. شكلوا دائرة حول الخال حكيم، وجلس أحدهم على الحقائب للبكاء وآخرون في الصالة الفوضى والمضاء بلمبة واحدة يتباحثون أطلال العمر كله، مؤجلين القرار الصعب بلخول غرفة لا تزال تعبق برائحة الزهور و الثمع المحترق. وأخيراً، بدأ الخال حكيم في الكلام، وهو متأثر ايضاً بالألم المفاجئ، وفي الخارج كنت انصت لصوته كل فترة، صوت يتساعل ويجيب في الوقت نفسه، لا يشظله إلا الحفاظ على صوته في الهواء، حتى لا يأسف أصدقاء وشقيق اميلي في كل ثانية على الكارثة التي وقتت في بدايات الصباح. استغل الخال اميليو الفاصل ليعلن حضوري، ودعاني بحماسة شديدة بلت أنها تندد بأسلوبي الهروبي بوصفي مراقبة سلبية. وفي لحظة ما الحداد فتح السبيل للغسيل؛ أنا والخال حكيم تعانقا، وبينما نحن مستغرقون في العناق لعنتي، وهو يقول أنتا عشنـا فترة طويلة في الجنوب، في ولايتين متجاورتين، وأنا زرته مرة واحدة فقط، ويعلم الله منذ متي. كان ثقل الجسم والسن قد جطله أحلب قليلاً، لكنه حافظ على أناقته القديمة نفسها واكتسب الأدب غير الملتزم لأعزب وحيد وخلوق. طلب أن يفتحوا الباب، فقد كان يرغب في توزيع الهدايا وأن يجلس قليلاً على كرسي الانتريه وعرف أنه نفس الكرسي القديم. هندية التي كانت تعرف البيت مثل كف يدها أثعلت الأنوار واختقت في الممر وهي تزعم أنها ستعد قهوة؛ قرر الخال حكيم فتح الحقائب لاخفاء سوء حالهه، لأن كل شىء في ذلك المكان وفي الأثخاص الموجودين فيه لايزال يكسوه ظل اميلي الكثيف. بعد فتح الحقيتين، قدم علب هدايا ملونة حتى للأين لا يعرفهم، وفرش على البساط الفارسي الهدايا التذكارية الخاصة بأصدقائه الغائبين والتى كان سيوزعها بنفسه عليهم عندما يقابلهم. كيس واحد فقط ظل مغلفً، وسرعان ما أدركت أنه لن يتم فتحه قط. كان بعض الناس يبتسمون ويشكرونه عند إزالة غلاف الهدايا، كانت الههية مناسبة تماماً لذوق متلقيها ولهيئته؛ بالرغم من ذلتك كان الحماس فاتراً، وحينئذ أخذ الخال حكيم في سؤال كل حياة كل واحد، لكن في اطار حديث الجميع المتحفظ ، كان الأمر البارز هالة من الموت. لم يكن هناك شيء يمكن فعله، إلا الإستسلام دون خجل ولا خوف للألم الأي كان يخفيه ببذل الجه؛ كان يشاطر الآخرين الحداد والحنين، لكن بطريقة مبالغ فيها، شبه شرسة، لارجة أنه كان ياع هندية كونسيساو ترتجف من رأسها لأخمص قدميها، ولحسن الحظ أن المرأة البدينة لم تقع وهي تحمل الصينية المليئة بفناجين القهوة. فوجئت برد فعل الخال حكيم، لارجة أنتي لم ألحظ وصول أصدقاء ايميلي، يجتذهم النور، والأبواب المفتوحة على مصراعيها، وصوت ابن يشد انتباه الآخرين عند تذكر أمه، قال الخال حكيم، وهو يحتسي آخر رشفة من القهوة: هل تتذكرون كيف كانت اميلي تعملها؟، كاتت تطلب من الجميع أن يقلبوا الفناجين في الصينية، وبعد ذلك كاتت تتفحص أقواع القناجين البورسلان لتقرأ قدر كل واحد منهم من تثابك الخطوط السوداء الجافة من السائل . 
وكانت المحادثة تمتد طوال الليل، لأن الناس لا يمكنهم سماع القصص دون إبداء آرائهم أو تذكر شيئاً ما؛ بدأ شخص ما

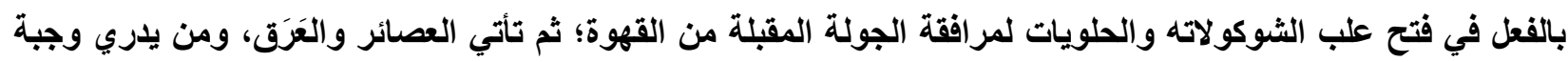
مرتجلة عند منتصف الفجر. كل هذا يحيلني إلى ايميلي، كان يدعني تواقةً لمعرفة حياتها في الفترة السابقة لعيشنا معاً.

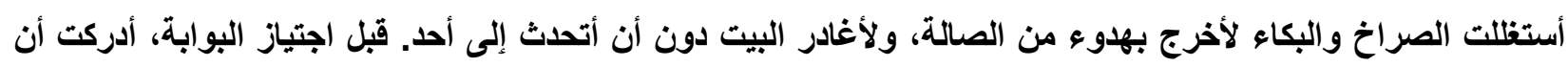

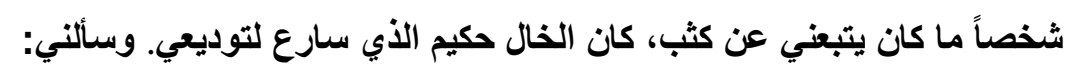
ـ الهل لايك أخبار عن سمارة ديليا؟ أجبت: ولا خبر. أعرف فقط أن الخال أميليو أبلغني أنها غادرت دوَّار "الباريسية" ولا أحد يطلم أين هي الآن.

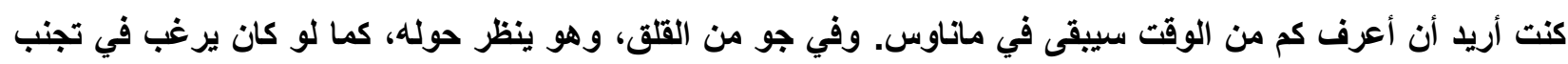

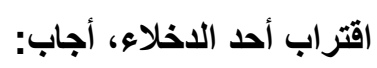
الوقت الضروري لروية أختي من جديد. قلت له أذن أنني سأود التحدث معه، بعيداً عن الضجيج، بعيداً عن الجميع. ذكرت الساعة السوداءو، وأمور أخرى كثيرة تركتي حائرة، وهو وعد أنه سوف يلتقي بي، بمجرد أن يستعيد سكينته ويسترجع أنفاسه.

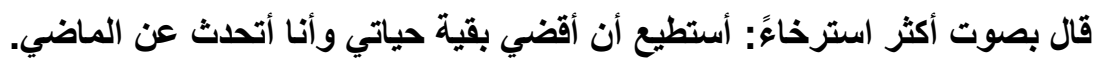

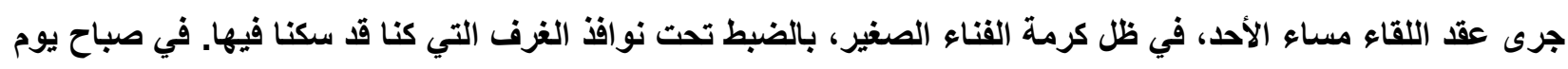

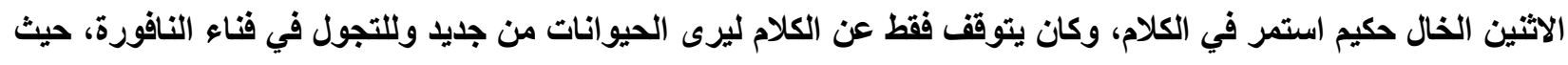

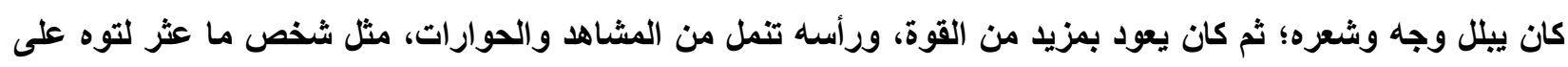

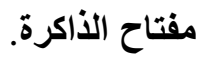


"كان لاي الفضول نفسه خلال المراهقة، أو حتى قبلها: دائماً. سألت والاتي عدة مرات لماذا الساعة، وبعد مراوغات

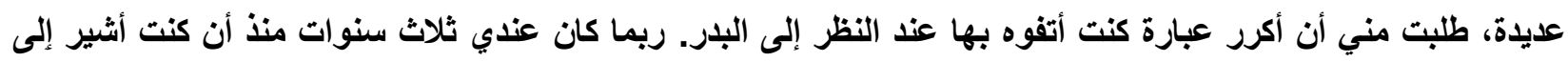

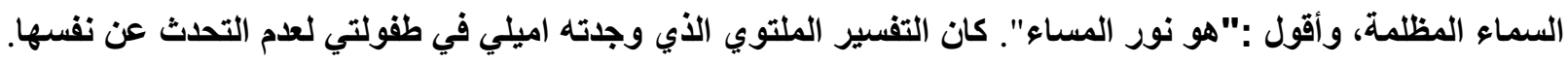
بعد سنوات، عندما انتزعت بضعة كلمات من هندية كونسيساو، بدا الأمر شبه واضح. حكت لي فقرة مظلمة من حياة اميلي. كانت أمي والأخوان اميليو وأمير قد مكثوا في طرابلس تحت وصاية أقاربهم، في حين فاضل وسميرة، الجدين، غامرا بحثنا عن أرض، هي الأمازون. لم تحتمل اميلي الانفصال عن الوالدائ.

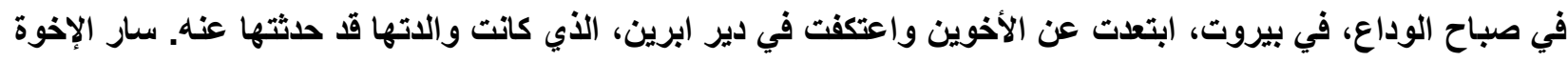

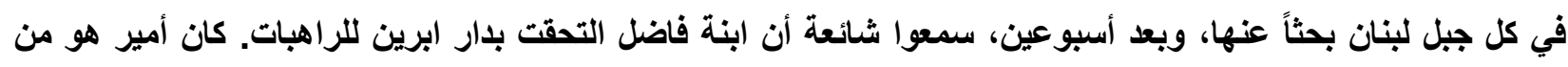

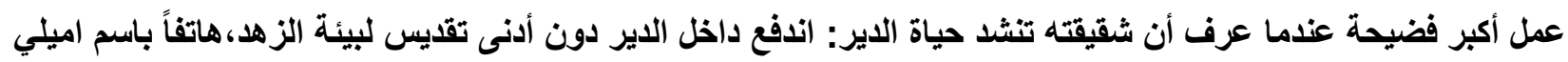

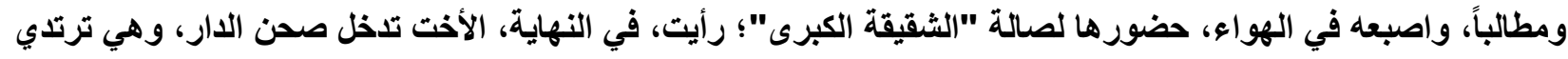

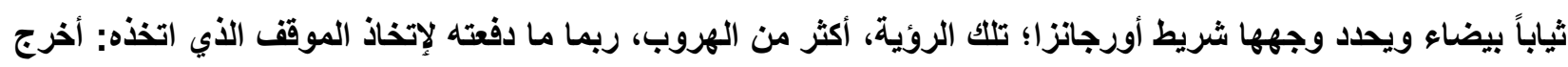
من جيبه مسدساً وصوب ماسورته للجزء الجانبي من رأسه، مهدداً بالانتحار إن لم تغادر الدير. ركعت اميلي عند قدميه

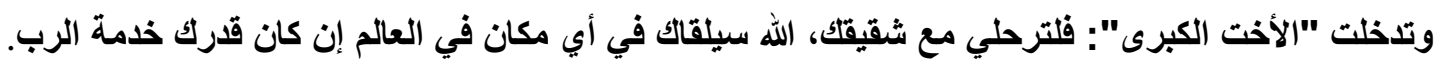

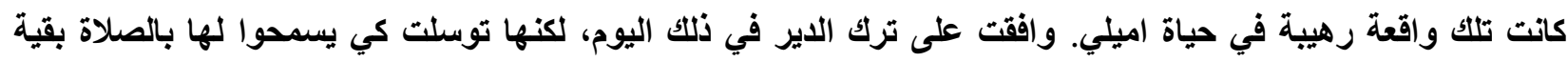

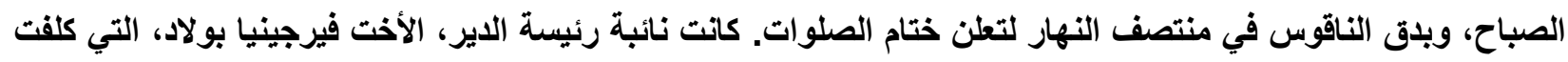

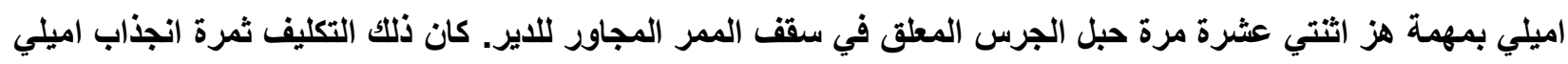

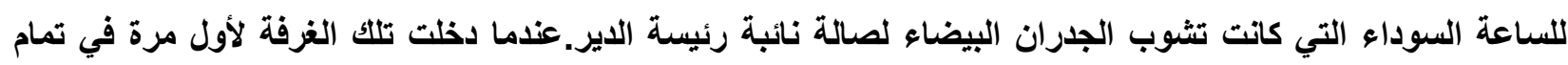

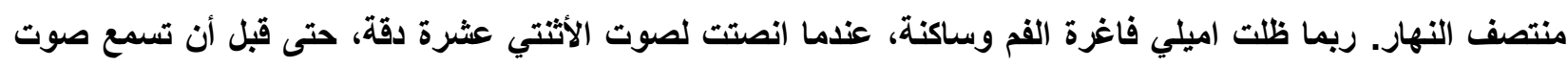

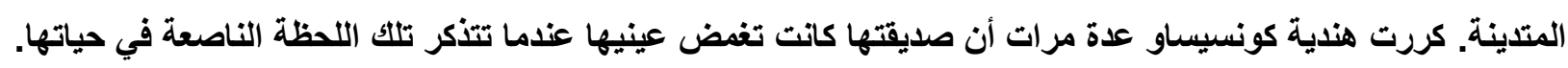

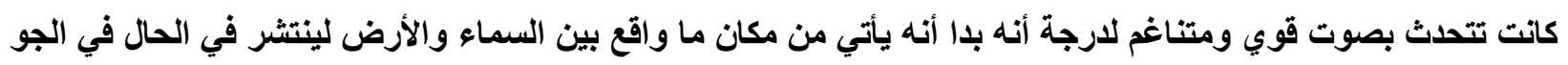

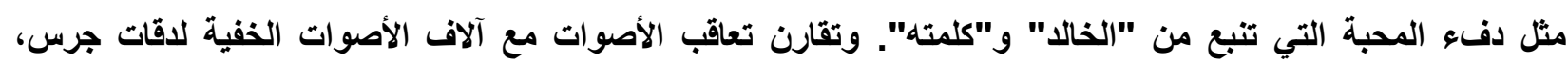

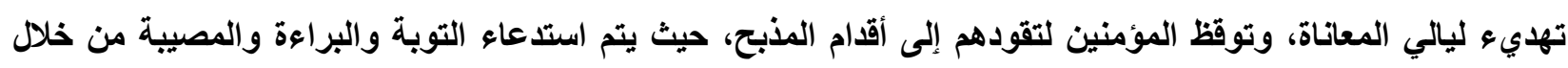
الصمت والتأمل. ريما لذلك السبب، كانت اميلي تتوقف عن الحياة في كل مرة يحلق فيها صدى تقريباً غير محسوس لدقات

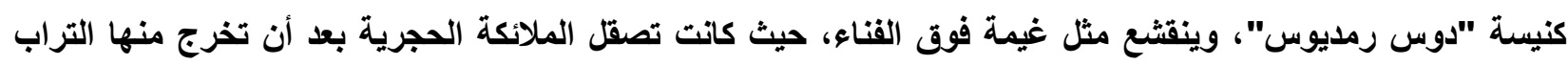

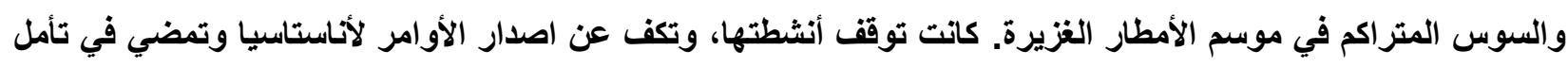

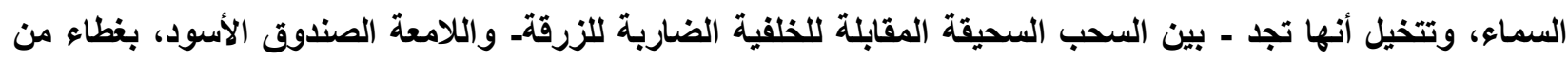

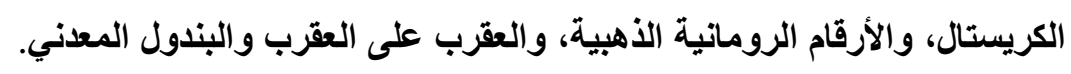

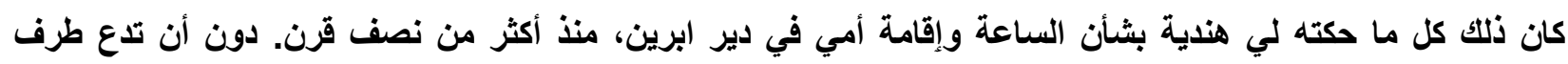

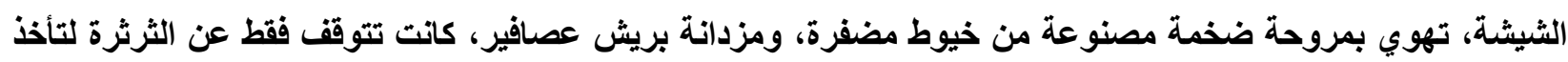


نفسها وتمسح عرق وجهها بطرف التنورة، دون أن تكترث بانكشاف النسيج الثفاف، الذي كان يفصل بشرتها عن قطن التونيك المزهر الذي لم تكن تخلعه قط. مع ذلك، يبدو أن هذه اللفتة المتبرجة ظاهرياً كاتت تبدو طبيعية لهندية، تسمح بخلق حميمية شبه عائلية بينها وبين "اطففال" البيت. (على الرغم من أنني كنت اناهز الثامنة عشرة من عمري، كان جسدي النحيل بجانب طبعي الخجول والمنطوي يزيد بثكل أكبر فرق السن بيننا). كاتت تهوي نفسها بحركة يد تنتهي بها أن تطول

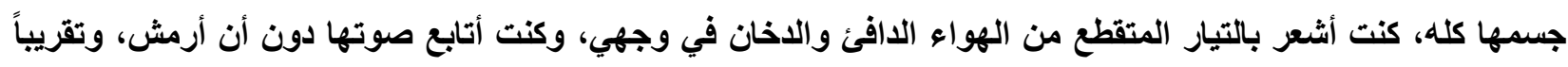
دون أية فرصة لتدخلي في الخط المتعرج للمحادثة التي كاتت تثارك فيها وحدها. في الحقيقة، كانت مأخوذة بالرغبة في التحدث كثيراً، في دقيقة مونولوج واحدة، كانت قادرة على خلط مزاجها المتعكر بالأمس بالحادثة التي وقعت عثية عيد الميلاد في الماضي البعيد، عندما كنا ما زلنا نعيش في الدوَّار الباريسية. كنا نتجمع كلنا في مطبخ البيت الكبير الوردي، بإستثناء والدي الذي كان ينعزل في غرفته أو يذهب للتريض في "المدينة العائمة"35، حيث كان يدخل "الأكواخ المائية36". للتحدث مع مواطنيه المعروفين له، ومع الكابوكلو 37 الذين وصلوا حديثاً من أقاليم أعالي النهر، وبعد ذلك يسير حتى الميناء لزيارة المتاجر والسفن.

كانت اميلي توقظني قبل بزوغ الفجر لنقطف الزهور من الحديقة؛ بعد ذلك كنا نسحب سمارة من السرير المعلق ونتوجه بالترام إلى حي الفرنسيين لثراء باقات كريب الياسمين وجهنمية جلبرا. كنا نصنع بخيط أصفر وإبرة من الخشب قلائد وحلي لتقديمها للزوار، ولكل كأس من الخزف اميلي كانت تدبر بتلة بيضاء وتبعثر ياسمين بري على أرضية المخدع. كاتت نساء الحي تساعد في المطبخ، تعد وتمد عجين "الباستيل38" و الجلاش. كاتت طبقات رقيقة من القمح ممتدة في جميع أنحاء البيت، نسيج شفيف يشكل كهوف ظل حيث كنا نلعب لعبة تخمين الآخر من ظله أو لصث الوجه في أسطحه التي كانت تثقولب مع الجلد أو تغطي الرأس مثل قناع أو قلنسوة. كان الخال اميليو يقوم بالتسوق، وذبح الأغنام وسلخها، يلوي أعناق الطيور ويستل حناجرها بحد السكين ليتدفق الدم بوفرة ، كما كان والدي يطلب منه. مرة واحدة فقط استخدموا فيها طريقة أخرى لذبح الحيوانات. كاتت عبارة عن اسكار الطيور ولوي أعناقها لترى العالم باهتاً يدور مثل لعبة الأعلى. كانت الطيور تموت ببطء، منتشية، العيون نقطتان من الجمر والرقبة متفتكة مثل الخيوط. كان ابي يقول "هذا الاستشهاد لا يمكن إلا أن يكون عملاً مسيحياً"، وهو يعلم أن هندية قد فعلت ذلك في بيوت أخرى وأنها كانت ممارسة واسعة الانتثار في المدينة. عشية عيد الميلاد، ظهرت هندية في البيث بزجاجة كبيرة من "الكاثـاسا393" وقامت بنفسها باسكار اثنة عشرة دجاجة وأربع ديوك رومي ، لقت رقبة كل طائر بحبل توكوما 40، ودعت الجيران لمشاهدة الهولوكوست. لم تغادر ذهني قط روية

(Cidade Flutuante) ${ }^{35}$ ئمة (Palafita)

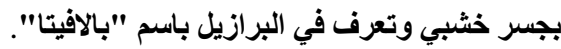
(Caboclo) ${ }^{37}$

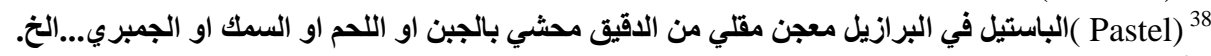

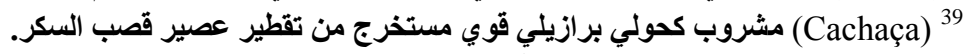

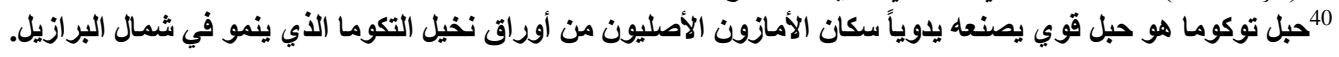


الطيور وهي تتقافز في دوائر ورقابها متللية، مختنقة مع حركتها في كل قفزة خانقةً الجارة. هندية تصفق وتقهقه، غير عابئة باظهار اللثة المتخلخلة، وغير مبالية بسحب الذباب الذي كان يغطي خصلات شعر ها المتلدي حتى منتصف ظهرها.

في عصر ذلك اليوم شاهلت كل شيء من بعيد، بفضول ونوع من الخوف. كاتت هندية تعامل أي طفل كما لو كان ابنها، تمطره بوابل من القبلات، والأحضان وتوزع الكلمات الحانية على ضحاياها القليلين الذين كانوا يعيثون في محيط بيتها. لكن ذلك التفاني كان يبدو مظهراً من مظاهر السادية المتقتة، لأن المحبة المبالغ فيها التي كانت تحوطنا بها أمرأة مثل فئل

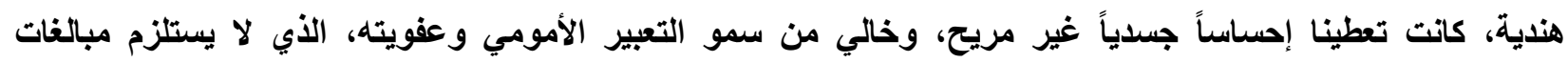

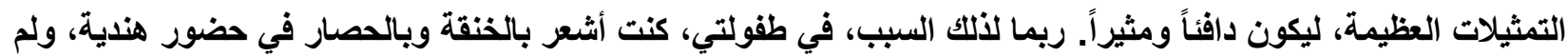
يكن ذلك بسبب قبح جسمها وإهمالها له، بقدر ما كان بسبب الطريقة التي كانت تلحقني بها، أو بالأحرى تلاحقني بها،

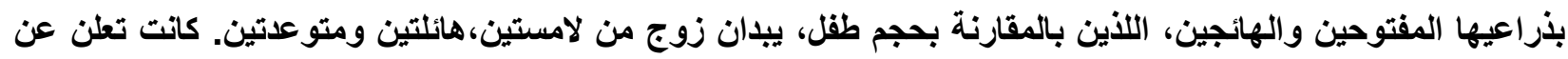
زيارتها بالتصفيق المدوي، تنادي "(ميلي" بصراخ صوت أجش يأتي من اللثة ويتردد صداه في غرف "الباريسية". كنت أنا وسمارة نخرج مندفعين بإتجاه المكان الأكثر انزواءً في البيت، حيث نمكث متثرنقين على سرير معلق، ننصت إلى ترددات

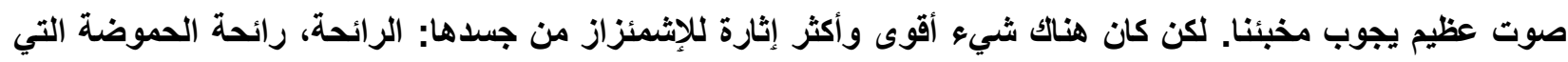

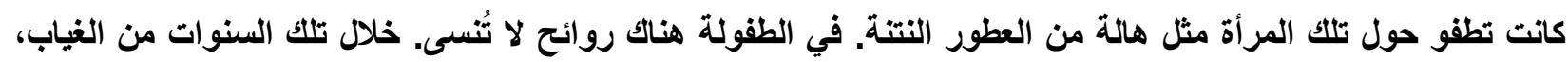

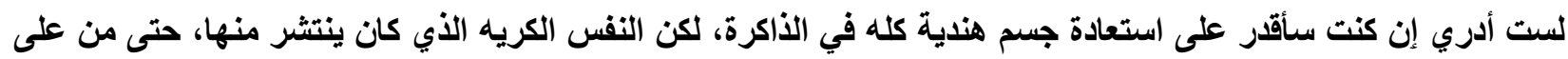

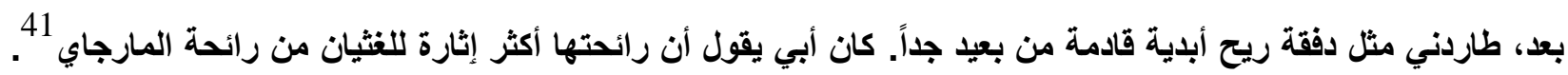

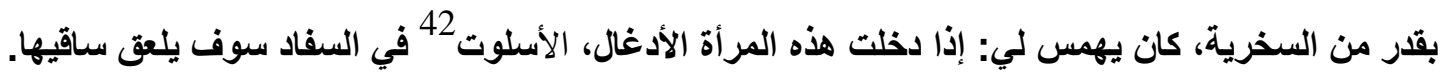

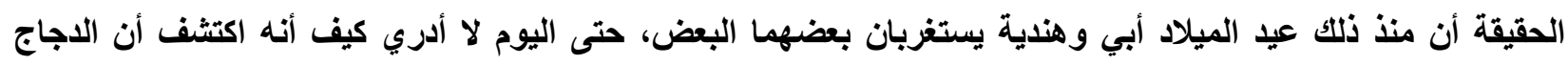
و الديوك الرومي قد تناولت "كاشاسا" قبل خنقها. خلال الحوار قالت هندية التي كانت كذلك قاسية:

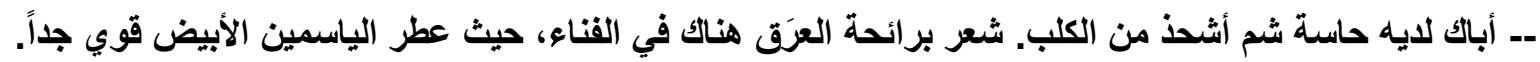

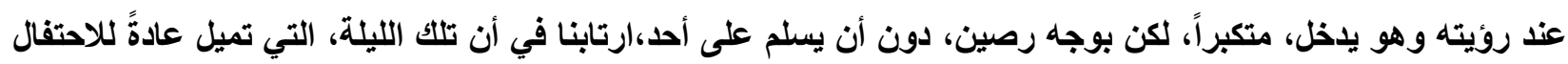
و الثراهة، يتهددها خيط رهيف ومثدود قد ينقطع فعلاً عند ذروة الضحك، والمداعبات، والمغازلات، والرقص ومديح الطهي الوفير وزينة الصالة: مشهد ملون ومتباين مثل المشكال. في أحد أركان الصالة كانت شجرة الصنوبر التي تحاكي شجرة الأرز مليئة بتعليقات الزينة وعلب شفافة بها هدايا ملفوفة الكائة بورق حرير؛ وعلى أرفف الفاترينات ودواليب الكريستال كانت هناك صواني الحلويات والثثوكولاتة، والفواكه المجفقة

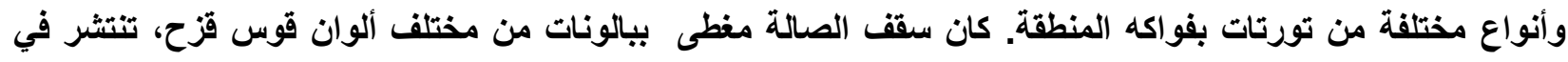

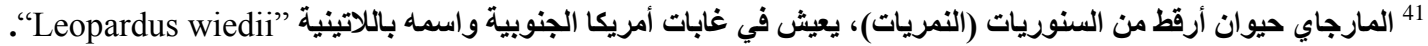

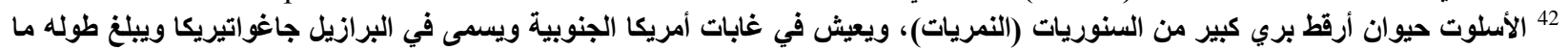

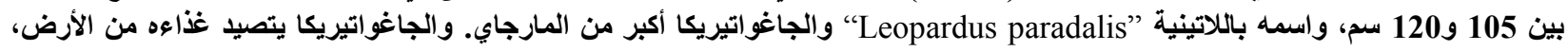
بينما المارجاي يلتقط غذائه من الأثجار. وذيل المارجاي أطول من ذيل الجاغواتيريكا ومخالبه كذلك أكبر. 
جميع أرجاء البيت كرات سيبا4 ملفوفة في ورق كريب، تحوي في طياتها التوفي والثوكولاتة المحشية بجوز البرازيل 44. كاتت هناك العديد من الأثياء الملونة التي تومض داخل الفاترينات وخارجها لارجة أن حفل عيد الميلاد كانت يذكرنا باستعادات الكرنفال؛ كاتت تنقصنا فقط الأقنعة والملابس التنكرية ليتحول العثاء الايني لعيد وثني. قبل منتصف الليل، كان الفونوغراف يقدم أغاني برتغالية وشرقية على وقع التصفيق، والجيران الأجانب، بملابس مناسبة،

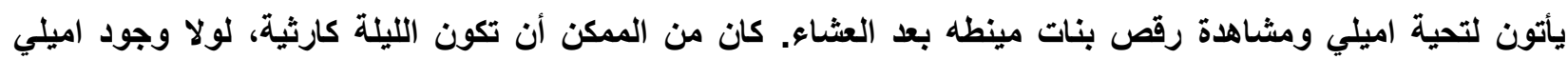
وزيارة غير متوقعة. مكث ابي في الغرفة خلا الثفق، وجزءً من الليل؛ كلنا كنا نشعر أن في سكوت الرجل الذي انزوى كانت هنايك ثورة صامتّة تفيض بحذر. ظلت اميلي منهمة في أعمال عديدة، على الرغم من أنها تعرف أن الناس حولها كانوا يتحركون بقلق،

$$
\text { ويستشعرون اضطراب وشيك. }
$$

سألت ما الذي ضايق ابي. قالت هنديةـ نصحت أمك بالذهاب للتحدث معله، لكنها لم تكن لتداهن أي أحد.

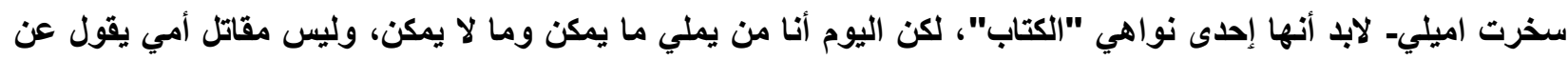
نفسه أنه "النبي" و"المستتير". كان البيت يعج بالفعل بناس عذما سمعنا الخطى على الأرض والاصطكاك الجاف لباب تم غلقه بعنف. كل الأصوات سكتت،

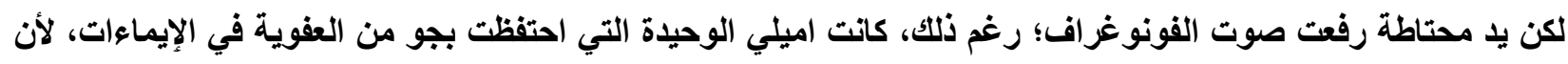
الجميع هناك كانوا متحجرين، كما في بورتريه عائلة. عبر هو الصالتين وحيز المحل بكبريائه المعتاد، وحيا برأسه الناس الاسبال دون النظر لهم. من كانوا يفكرون في مد ايديهم له استراحوا لأنه كان يحمل صرة من المؤن كما لو كان سيعبر صحراء.

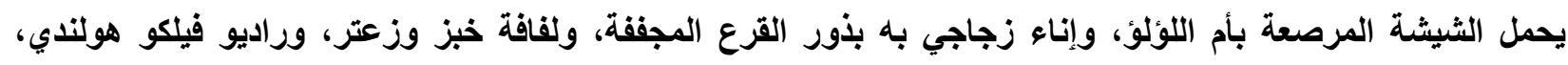
ثمانية نطاقات، يلتقط ترتدات الغرب والثرق، ويضبطه على محطات القاهرة وبيروت التي كانت تنقل له آخر الأخبار، وتبث برامج موسيقية و الصوت القوي لمؤذن سمتثه، بعد ذلك بسنوات، في التسجيل الذي أهداه إياه.

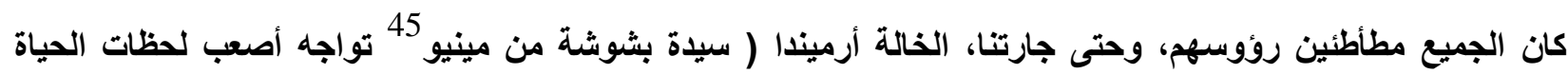

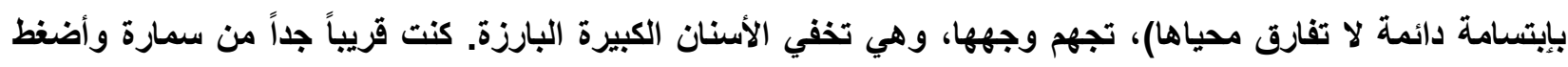
على يدها المبتلة، لكن أعتق أن كلانا نتصبب عرقاً بارداً. ذكرت هندية أن أبي قادر على محقها بنظرة، لكنه لم ينظر لأحدا لإنا

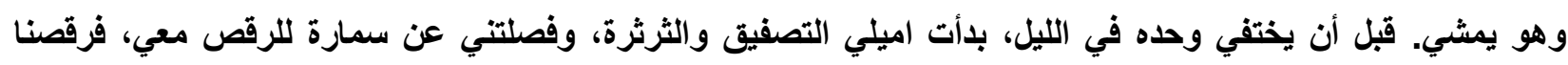
وضحكنا دون ظل ابي في البيت المضيء. وكأن بورتريه ينتعش أو مجموعة منحوتات تتحرك، وصاحبونا الأشخاص

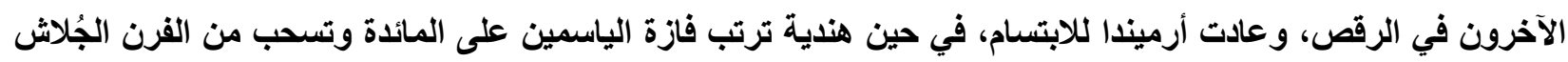
و والصفائح.

43 شجرة ضخمة تنمو في المناطق الاستوائية وبذورها مصدر لألياف قطنية الملمس. 44 بذور شجرة جوز فئه البرازيل نتكون داخل ثمرة خثبية كمثرية الثكل، وتحوي كل ثمرة من 12 إلى 24 جوزة. ويكون نوى الجوز غنيًا بالزيوت 45نطقة نهز مينيو الذي ينبع من جنوب جاليسيا ويصب في المحيط الأطلنطي شمال البرتغال ويبلغ طوله حوالي 340 كم. 
واصلت هندية حديثها، وهي تلخن بقلى، تبلع الاخان وتتنفس في الوقت نفسه ويدها التى تمكك المروحة ترتجف مثل

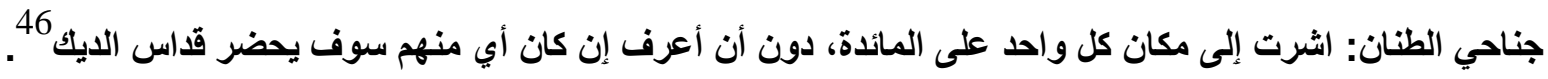

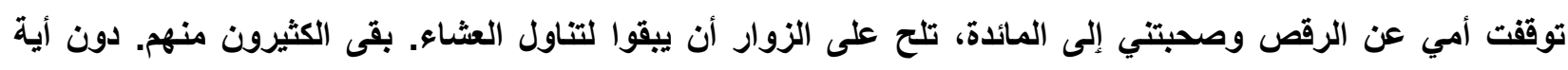

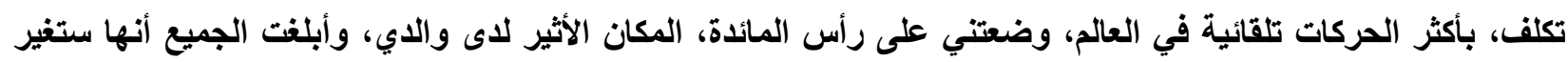

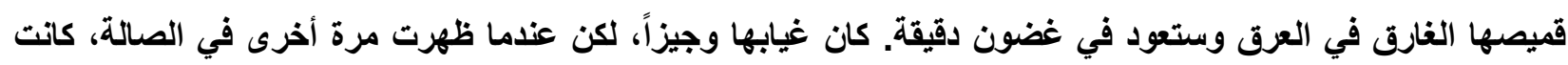

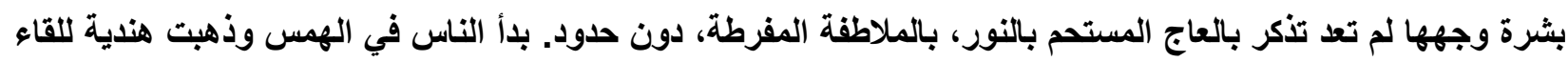
صديقتها ، في محاولة لتجنب الإحراج.

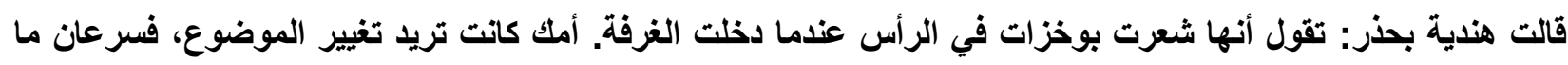

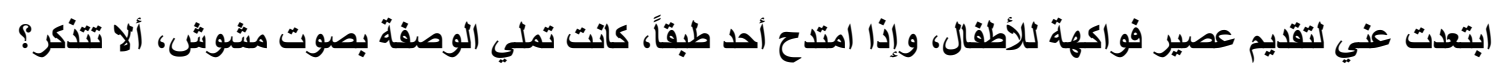
أتذكر أنها لم تذهب بعيداً عني بينما أنا آكل على مضض. كانت تضع الطعام في فم سمارة، تراقب شهيتي، وتناولني لقمة،

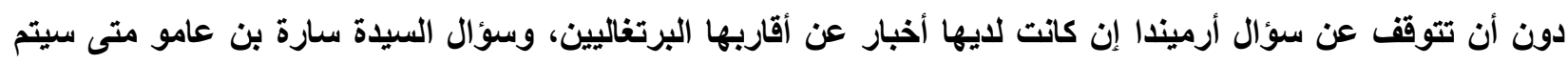

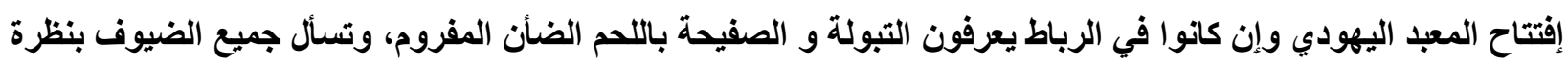
ساطعة وشاملة، هل يعرفون بالفعل أما إذا كان دورنر في طريق عودئه للمدينة.

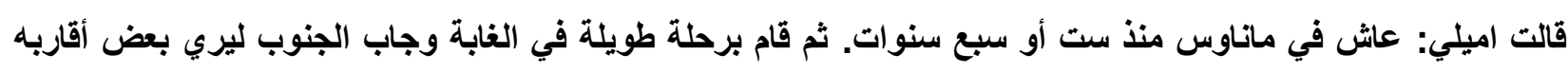
من جديد. ذكرت ازميرالدا: في ذلك الوقت كنتِ عزباء. أضافت اميلي وهي تبحث بعينيها عن برواز بيضاوي على حائط الصالة الأبيض: عزباء، سعيدة وتعيسة. يعرف ذلك فيراء الألماني زوجي وكان صديقاً لأومير 47

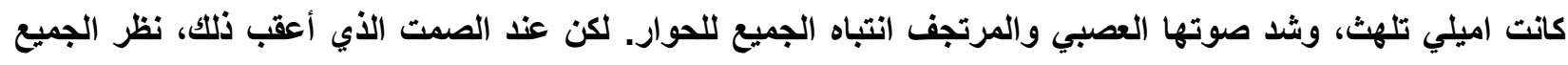

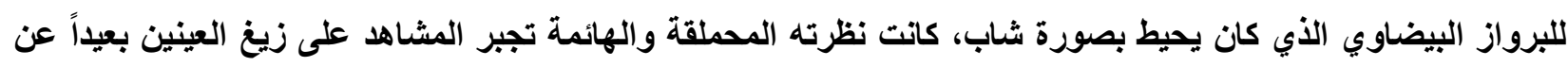

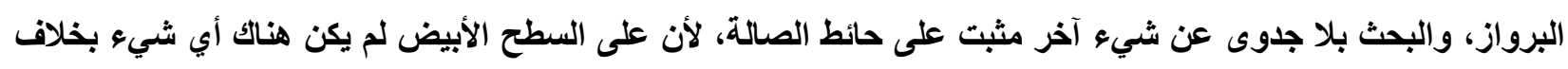

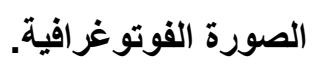

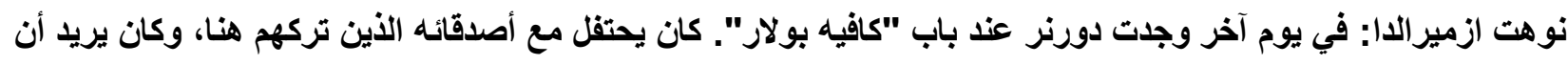

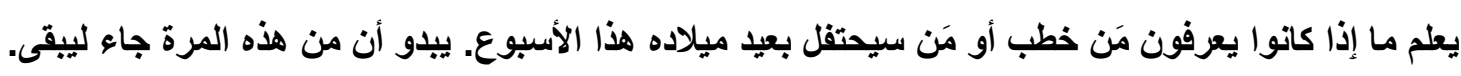

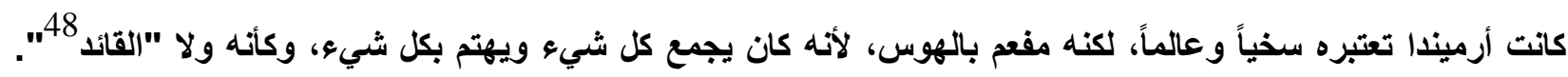

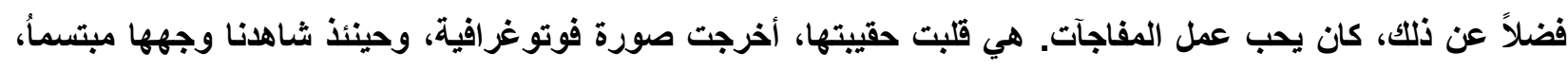
شاحبأ وشبه مرعوب عند منتصف الناقذة، بين أواني زهور القرطاسية.

(missa do galo) ${ }^{46}$ (اس في منتصف ليلة عيد الميلاد وسمي بقداس الديك للاعتقاد بأن ديكاً قد صاح مبثراً بميلاد المسيح وفي رواية أخرى

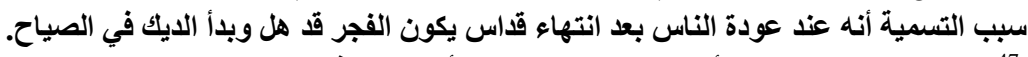
47 استخدم الكاتب تصغير "أمير" وتصغير النير بؤ الاسماء أمر شائع في البرازيل للتنليل. 
قالت أرميندا وهي تمسك بالصورة الفوتوغرافية: هو أخذني على حين غرة.

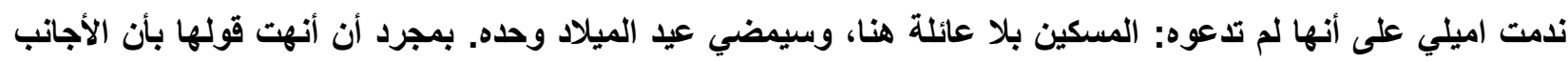
دائماً موضع ترحيب، سمغنا التصفيقات، والتحية بطاب مساوكم وعيد ميلاد سعيد للجميع. ضحك الأطفال عندما لمحوا

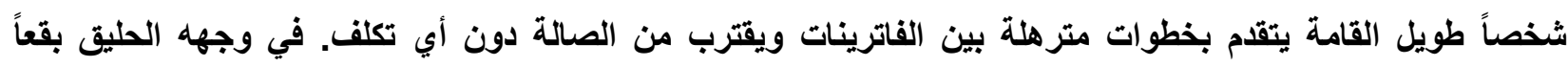
حمراء، ويلف قبضة يده اليسرى بربطة علبة، يمسك بها بثبات وينهم باز يقبض على فريسة. و هتفت أرميندا بلكنة مطابقة

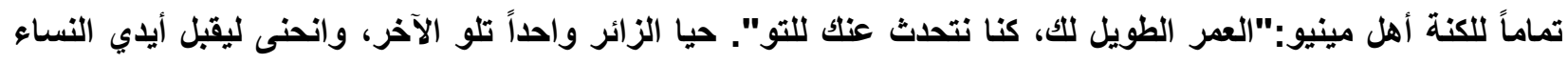

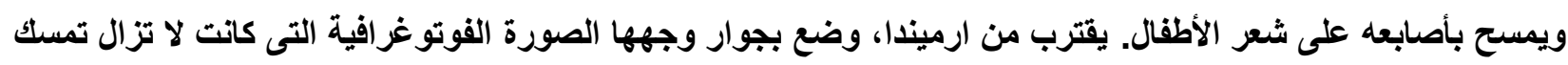

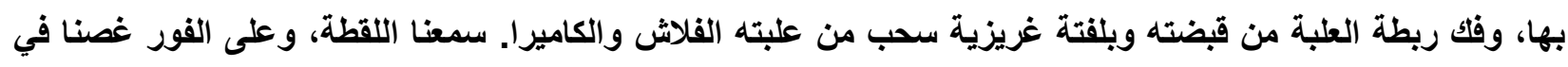
العمى الخاطف للوميض، الذي أباض كل شيء حولنا. عندما عاد الأثخاص والأثشياء للظهور، كانت الأرميندتان لا زالتا

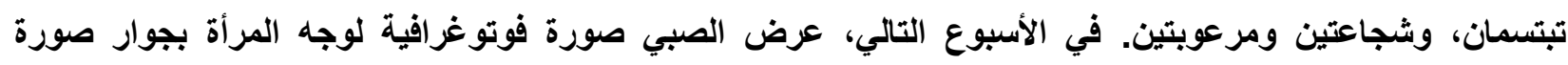

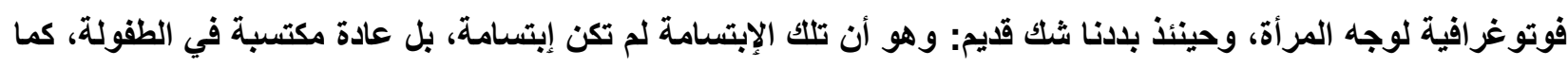
كثفت جارتنا إزمير الا لهندية كونسيساو.

ليست فقط أسرة "بوفوا دي فارزيم"49، لكن كل الجيران يريدون معرفة ما حدث ليلة عيد الميلاد. كانوا يثكون بالفعل أن أبي لم يكن قد نام في البيت وأنه لا يزال مختفياً دون أثر. كانت الزيارة غير المتوقعة للمصور في منتصف الليل بمثابة عزاء لاميلي وحالت دون مزيد من الإحراج. لاحظت هندية: دون ذلك الالتهاء، أمك لم تكن لتتوقف عن الكلام وتناول الطعام، دائماً ملتصقة بك، تقذف بكات بكات وتلتهم

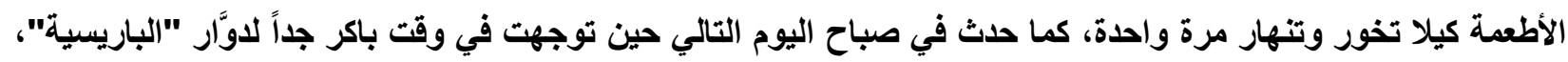
ووجدت نفس صخب أمس. كتيبة من نمل النار، يجذبها شربات الجلاش، والردة والفتات، تغزو الفاترينات؛ على المائدة وعلى الأطباق كان مبعثراً خليط من العظام ونوى الفواكه وقثورها، وعلى صحون البورسلان كانت أسراب الذباب تتزايد. كان المشهل الريفي على تطريز

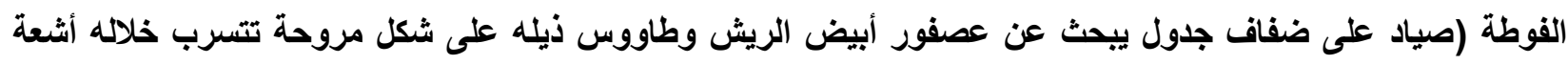

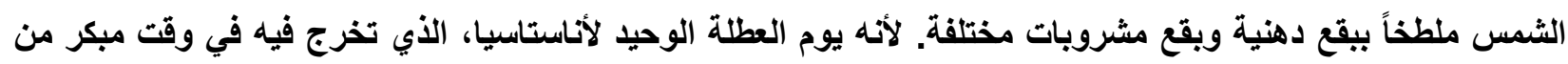

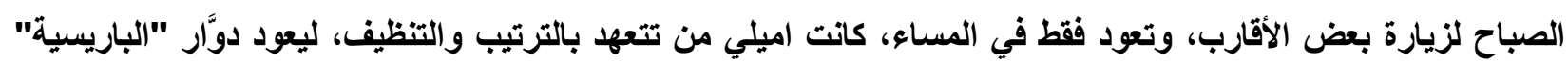

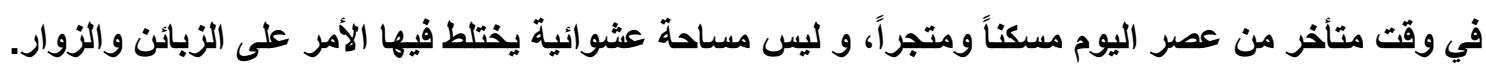

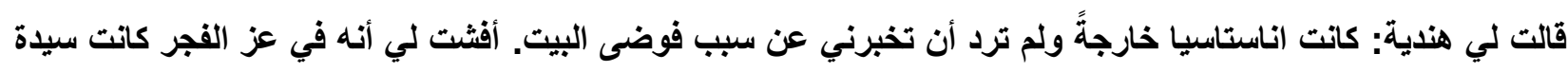

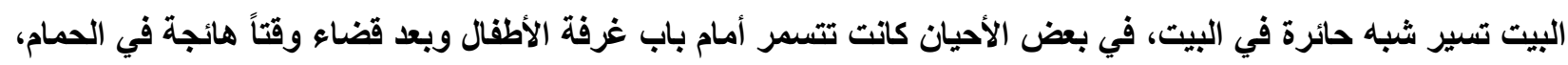

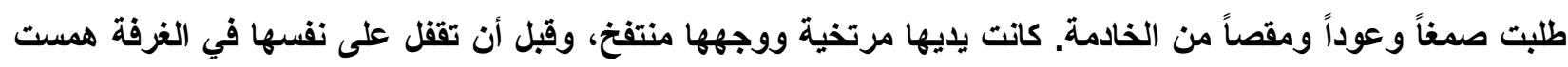

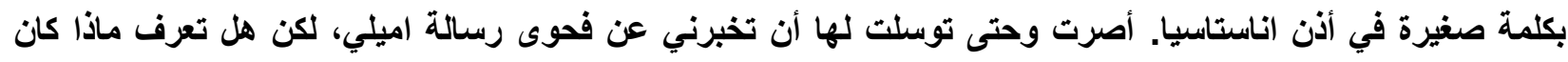


ردها؟ "على جثثي، يا خالة. السيدة ذكرت لي أنه سراً." ثم نظرت لي بروح من التفاني والمسؤولية، واختتمت قولها:" أنا ذاهبة لأن الساعات تطير. يمكن أن تدخل الست الغرفة، السيدة اميلي مستيقظة بالفعل.". في الحقيقة، لم تكن والدتك قد

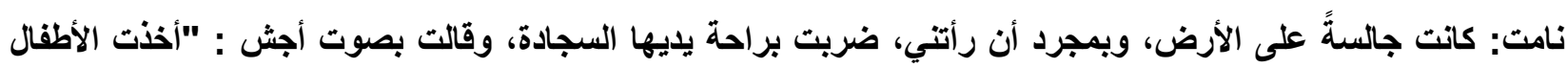
إلى بيت ازميرالا، حيث سيقضون اليوم. اجلسي الآن وحاولي أن تساعديني، فالعمل لا ينتهي". تأسفت هندية أن الغرفة الآنة

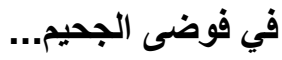
توققت عن الحديث، أخفت وجهها بالمروحة، واتكأت على كرسيها. التزمت الصمت لحظة: هل لتتعش الأكرة؟ هل لتأخذ

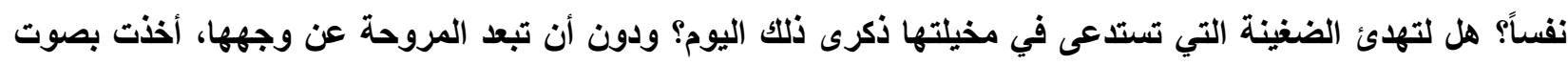
مشحون بالغضب والعار في احصاء عدد قديسي الجص المسحوقين، وقديسي الخثب المكسورين بشكل بربري، عذراء

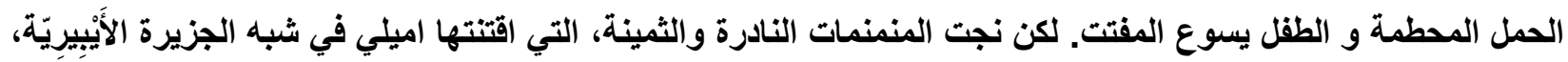
وكنلك المصلى من خثب الماهوكني 50 وصورة عذراء لبنان؛ لا يزالان كلاهما في حالة سليمة، بمعزل عن سخط أبي خلال الثفق وجزء من الليل. بدت الغرفة أنها تعرضت لكارثة إعصار أو صرخة واحدة من الله العلي القدير. كثفت هندية مجداً

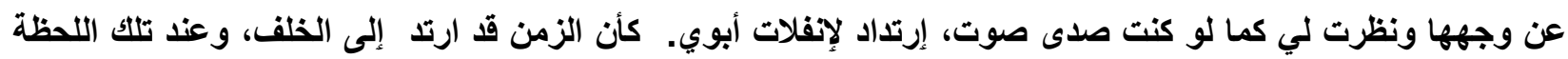
كانت هي تثاطر اميلي الآهات، وأخذت أنا في التواري بعد أن دنست منطقة الغرفة. ومع ذللك، لم أفتح فمي، فقط كنت أجتر

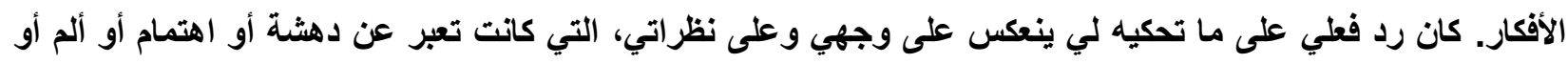
تعاطف. لماذا تتحدث كثيراً عن ذلك؟ لا لإتهام أبي، مدمر نخائر القديسين التي كانت تغذي أيام الصديقتين، ونعم للخلاص

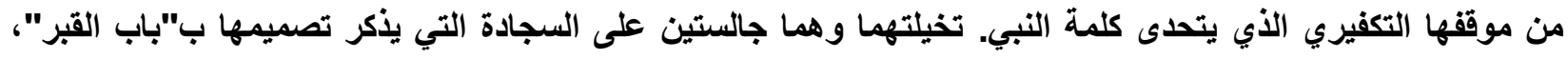

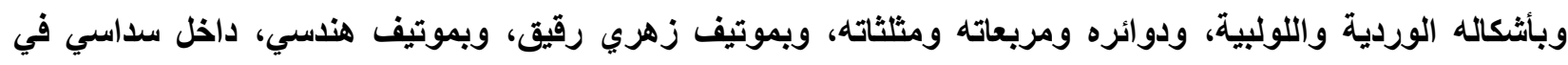
دائرة. لم تكونا تعرفان (ربما كان أبي الوحيد الذي يعرف) أن التصميم الهندسي في تلكل السجادة - حيث كانتا تلتقطان شظايا

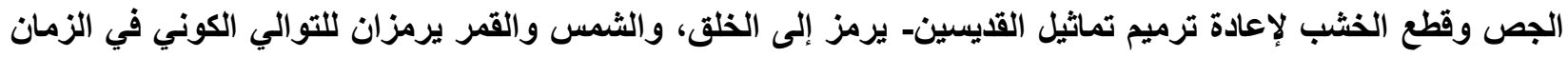

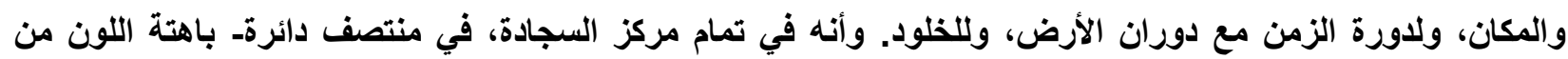

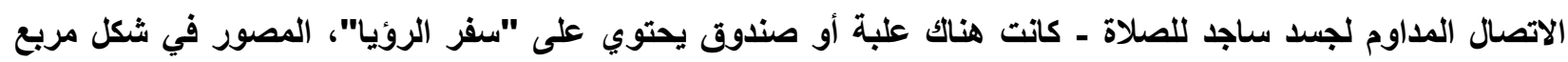
أصفر صغير. بينما هندية تحكي كيف كانتا تلصقان الثقفات، وتعالجان خصلات التماثيل الصغيرة وعباتتها بخضاب من نوى الفواكه وقثورها، وتبحثان ببصر هما الحاد عن شقفات الجص المتناثرة على السجاد، كنت أفكر - بضحكة مكتومة. فيما حدث في الأيام التالية لليلة عيد الميلاد تلك. حتى ذلك الحين، لم يكن الدين يتسبب في خلافات جدية بين والايدي. كان يتلقى بثكل

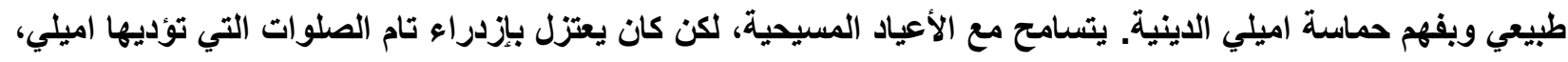

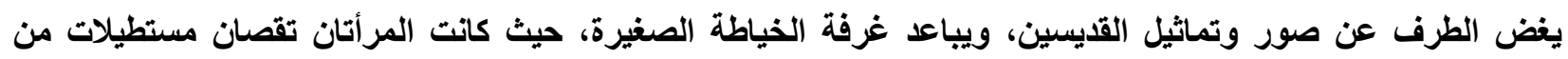

الخثب الماهوكني مصدره أمريكي أو أفريقي ويثبه إلى حد كبير خثب الزان إلا أنه يختلف عنه من حيث اللون والصلابة والمقاومة، فلونه مانل إلى الأحمر، ويعرف بمقاومته للارجات الحرارة العالية. 
أوراق النباتات وتلصقتها لتفصيل أشكال صغيرة وملونة لقديسين، كان سيتم التبرع بها ليتيمات مدرسة السيدة مريم معينة

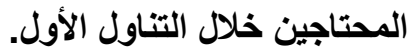

تم تخصيص اليوم كله لترميم الأشياء المقسة. في آخر العصر، عادت التماثيل الصغيرة ببقع الطلاء وعلامات تصدع إلى أماكنها على القواعد الخثبية وفي المحاريب.

واستطردت هندية: كنت منهكة بالفعل، لكن أمك، مثل أحد يعيش لحظة عمى أو ثمالة، كاتت لا تزال لايها القوة لترتيب الصالة، تطهر الفاترينات والأجزاء الرطبة من البيت، وتعد رابطة زهور لتزيين مائدة صغيرة مغطاة بمفرش أخضر. فعلت التهات

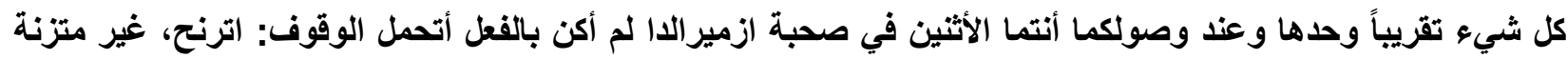

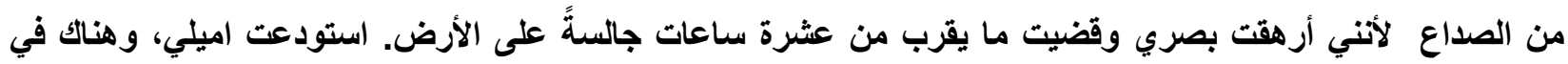

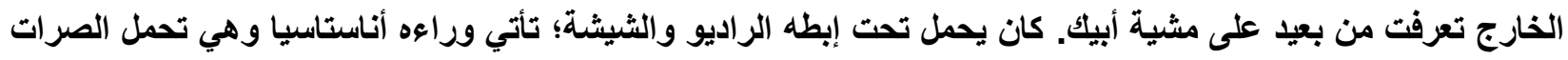

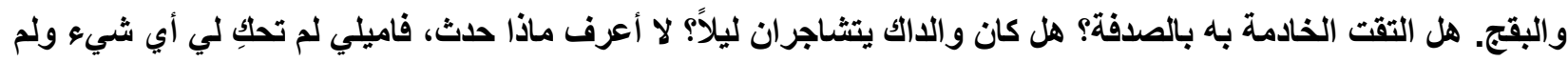

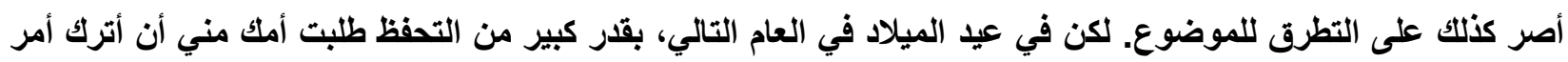
قتل الطيور لخالك اميليو، ذلك الملاك الفطن الذي عذدما استثعر الكارثة تغيب عن احتفال عيد الميلاد.

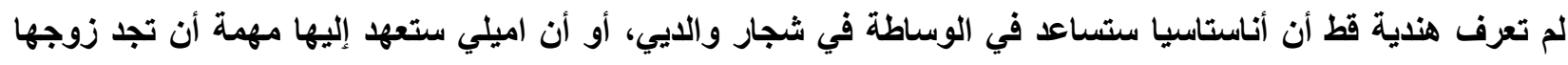
مهما كانت التكلفة وأن تعود به قبل العثاء. خلال عاصفة الفجر هي لم تنس أن تفصل له صحن من الطعام وصينية من الحلويات والفو اكه المجفقة وطاجن الفخار مملوء بكمبوت الجوافة. كانت تهمس للخادمة أن غضب رجل مغرم يهاً بالحنو والطيبات. وكاتت تقر: هما سلاحان قويان لتهيئة طبع زوجي الثرس. علمت فيما بعد أن اناستاسيا قضت يومها تبحث عن أبي، حتى وجدته في المدينة العائمة، يتحدث مع أصدقائه من أقاليم

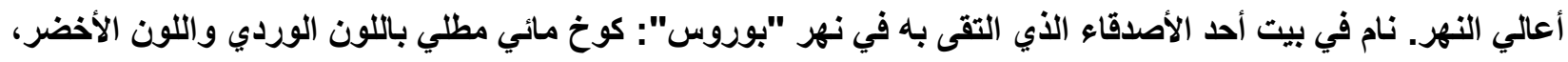
ومحاط بعلب كيروسين تمتلى بنباتات "كالاديم باي كولر" وسوسن، وأزهار برية. كان جالساً في وسط دائرة من الرجال

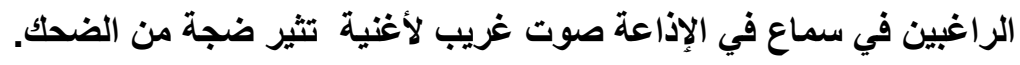
قالت اناستاسيا :عندما رآني وقف للتو وسألني عن أمك.

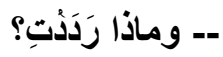

-- أنه منذ أمس وهي تنتظره لتناول العثاء، وكاتت سجادة الغرفة مشرقة مثل شمس الصباح. لخل الأثان معا إلى دوَّار الباريسية. مثت أناستاسيا بسرعة إلى المطبخ، لكن اميلي قاطعتها وأمرت: خذ عثاء الأطفال إلى الغرفة.

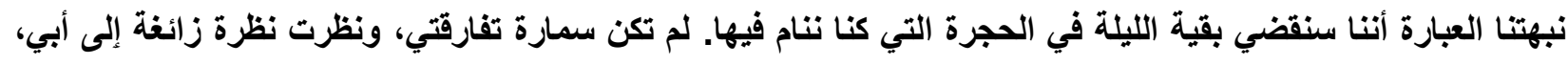
الذي لف حول الفاترينات ومر مثل شخص مجهول على بعد أمتار قليلة من باب غرفتنا. رغم ذلتك، ألقينا بتحية المساء في

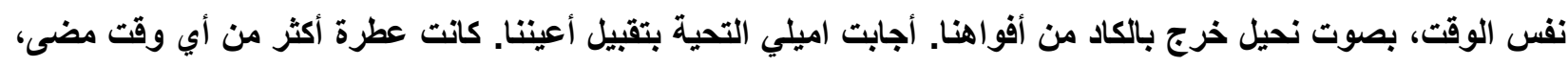

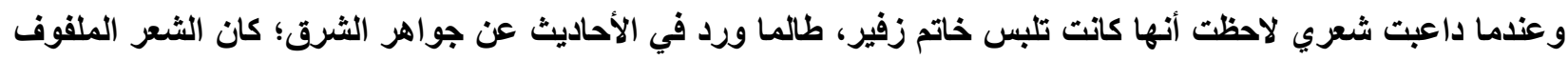

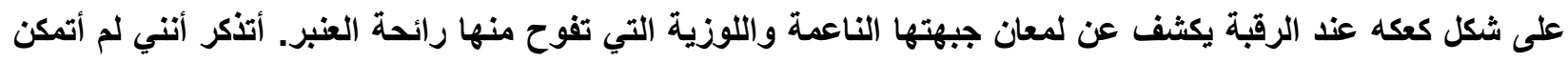


من أكل بقايا عشاء عيد الميلاد، وخلال شطر كبير من الليل تتبعت بأننيي اليقظتين حركات على الجانب الآخر من الجدار.

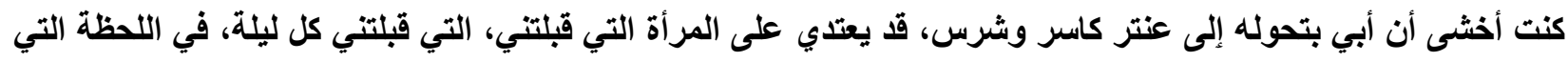

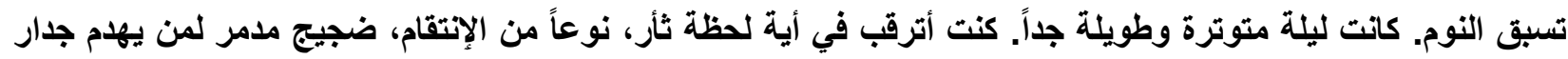

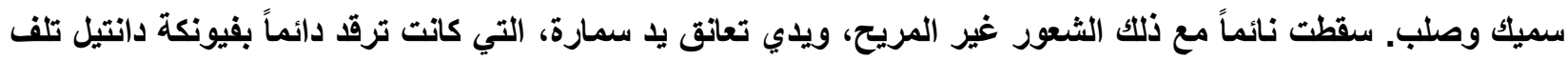

في صباح اليوم التالي، عذدما مررت بالدوًار، قبل أن أخرج متوجهاً للمدرسة، لاحظت أن أبي كان يحتفظ سراً بتمثالي قديسٍ

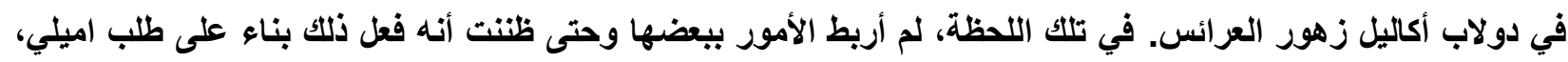

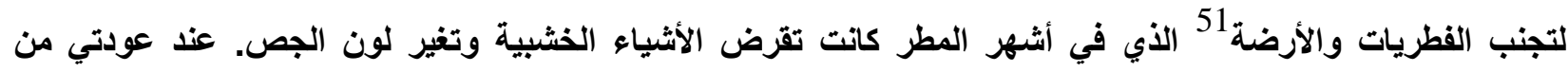

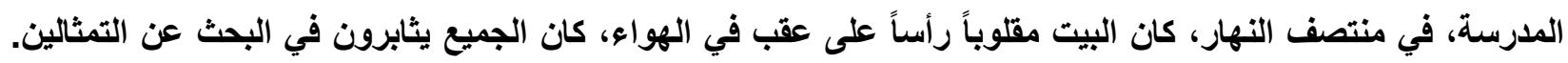
كاتت هناك بهجة على وجه أبي عندما لاحظ جزع اميلي، وجهها المرتاع، وصوت نعيبها تليه ضربات يدهان الها على المائدة

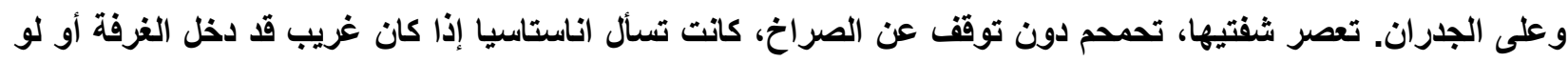
أنها لم تأخذ القديسين بالصدفة لتنظيفها. انتظرت ساعة القيلولة لأكثف لأمي عن المذبح المدنس للتمثالين. وهي لا تكاد

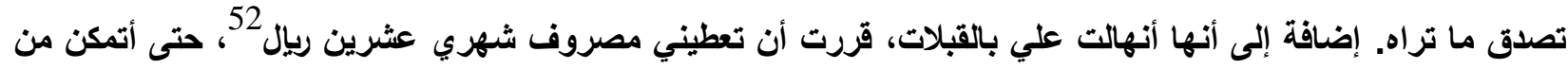

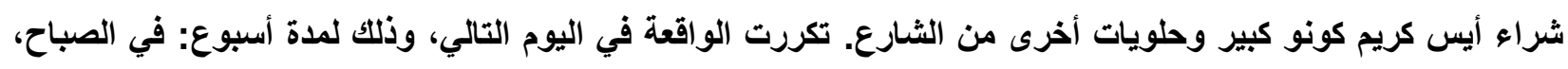

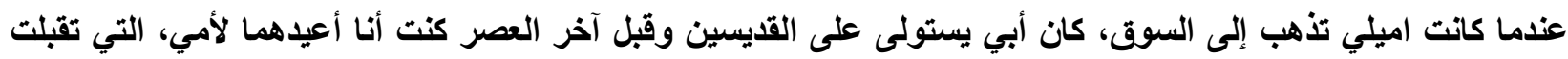
في النهاية هذه اللعبة بروح مرحة، لكن دون أن تكف عن المكيدة للانتقام. انتظرت بصبر شهر يونيو وفئ وفي صباح اليوم

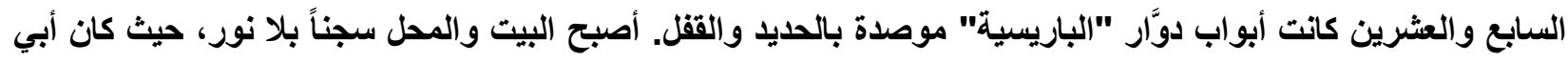

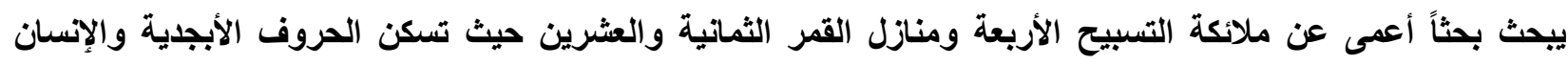
الكامل. على الرغم من أنه أوصد البيت كله، وعزله عن العالم، لم يحدث الفضيحة المتوقعة، ولم يحث أحد على البحث عن الإبعه

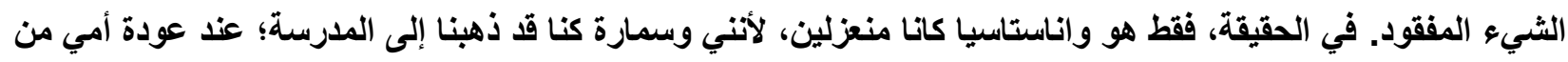

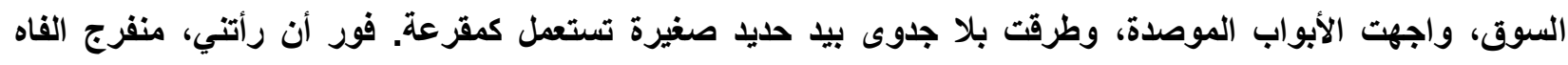
وسلبي أمام الواجهة العمياء، عانقتني بذراعيها، وقالت بإبتسامة إنتصار:

-- حبيبي، أيام الصيام تلك تدع آباكك يفق صوابه.

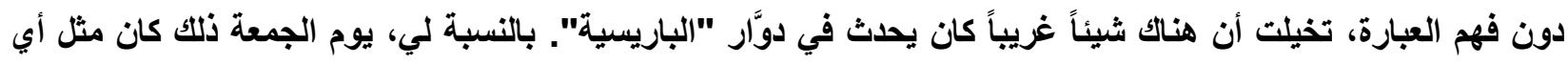

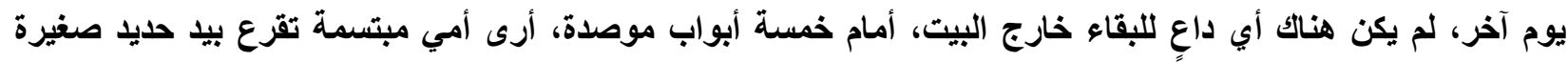

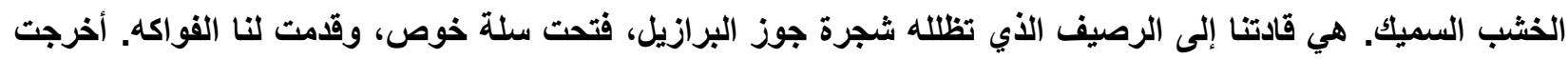
من حقيبتي دفتراً وقلماً رصاصاً، وبدأت في الكتابة، تحرك بتؤدةٍ يدها نحو مسار الثمس، تغرس الثرائ بين السطور السوداء

15 51 الأرضة أو النمل الأبيض حشرة كانسة وطولها من 3 مم إلى 2 سم وتتظنى على مادة السليلوز المتوفرة في الكثير من إستعمالات الإنسان اليومية

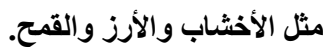
52 استعطل الكاتب (réis) وهو الريال القيم الذي ظل مستخما في البرازيل في النترة من 1790 وحتى 1942. 
خطوطًاً راقصةً، وغامضةً مثل الحروف الهيروغليفية. كتبت ثُلاثة أسطر، انتزعت الورقة من الافتر، طوتها وطلبت مني أن أضعها تحت الباب. بعد بضعة دقائق، عند طرف الباب الرئيسي، الذي انفتح، ظهرت اناستاسيا سوكوهو تهز رأسها،

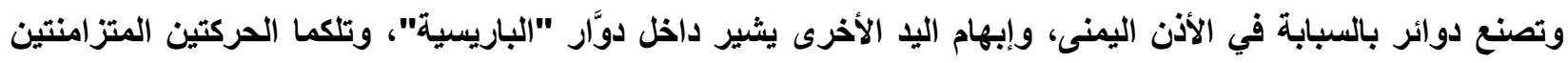
لجسم نحيف - يحدده طرف مظلم للباب- منحتانا نوبة ضحك، توققت فقط عندما غصنا في الظلام، وأنصتنا لصوت غليظ ومتناغم. قالت اميلي بفظظة:- "هذه علامة على أنه قد وجده...". عندها فقط علمنا أنها كانت قد أخفت "الكتاب"، وأن أبي كان قد فرض حظراً على البيت كي يمنع المكان المثلول أي إنسان من أن يلمح أي شيء قباء فيل ظهور "الكتاب".

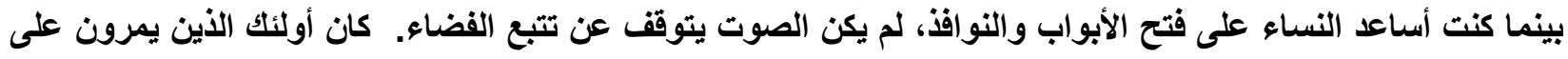
الرصيف يتوقفون للإستماع ويلقون نظرة على الداخل المنير الآن، دون إكتثاف مصدر الصوت الصارخ. كانوا ينظرون لنا

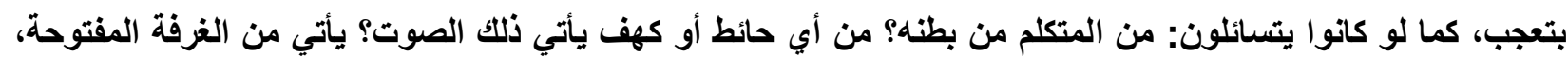
حيث كان جسد محموم صائم منذ أيام يصيح بصلوات آخر يوم. من حينها نمى داخلي افتتان، وفضول مفرط بالخطوط الثلاثة

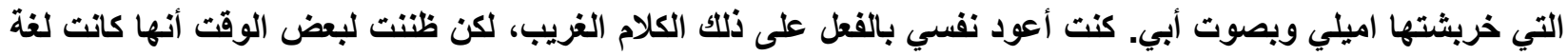

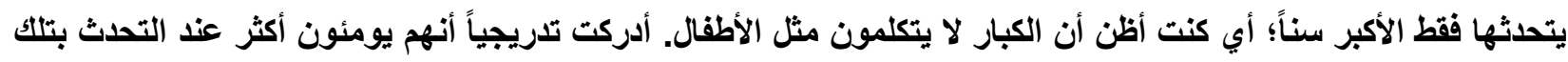
اللغة، وهناك حالات استثعرت فيها الأفكار من خلال الإيماءات. في إحدى الليالي التي كنت أتطفل فيها على حديثهم سألتهم إن كانوا يتحدثون عن الجار الجديد. أجابوني أنهم كانوا يتحدثون عني، وعن فضولي، وعن حقيقة أنني أريد أن أهيم بين

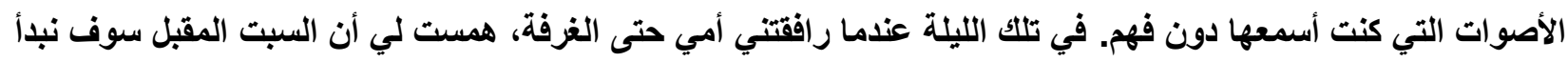
في دراسة الحروف الهجائية سوياً ـ وهي جالسة على السرير، أعترفت لي أن جدتها قد علمتها القراءة والكتابة، حتى قبل التهل

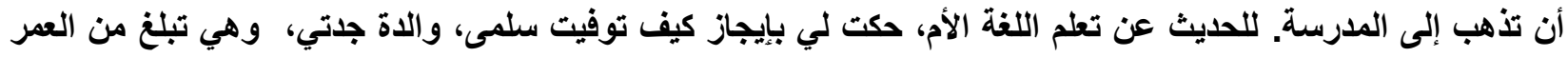

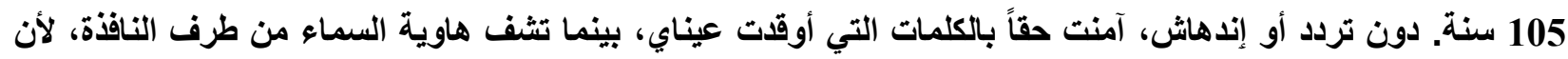

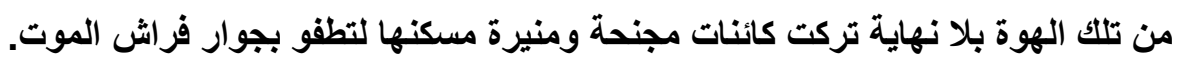
قالت سلمى لها قبل أن تغض عينيها: هم أكثر من عشرين ملاك وبزغوا بين الأطفال الصغار. ومن كثرة تكرارها لحكاية سلمى و الملانكة، انتهى بي الأمر أن حلمت بسلمى والملائكة. في اليوم التالي، تنبض الحكاية والحلم في ذهني مثل اختلاط مياه نهرين هائجين ليفضيان إلى نهر ثالث. كنت أترك نفسي

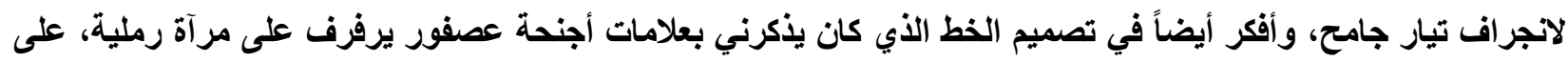

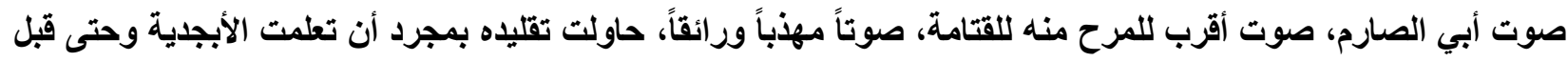
أن أنطق بكلمة واحدة في اللغة، التي رغم ألفتها لي، كانت تبلو وكأنها أكثر اللغات الأجنبية أجنبيةً.

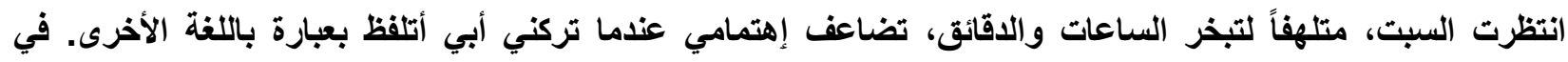

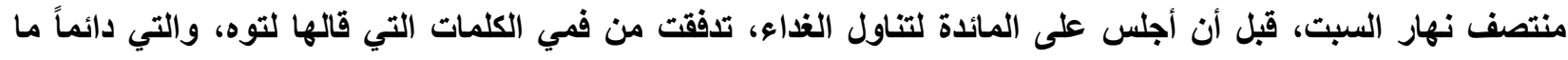

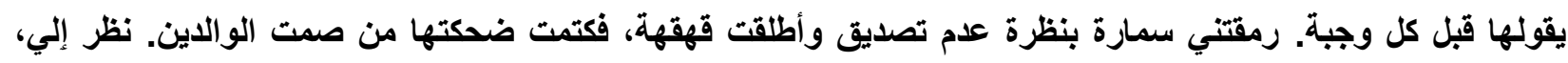
وتلك النظرة، التي استغرقت الوقت الذي تستغرقه تثنجة، تسطع مثل نظرة رضيع حديث الولادة قلق من أثث الإنفجار الأول 
كاتت أول الدروس جولات لإكتثاف الأركان غير المأهولة في دوَّار"الباريسية"، الغرف والحجرات التي تضيئها جزئياً

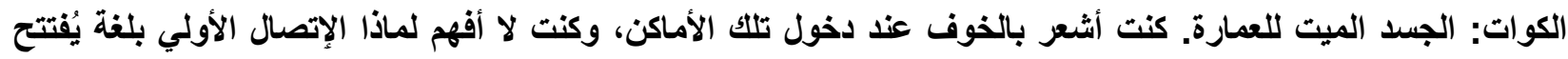
بزيارة أماكن خفية. بعد فتح الأبواب وإثعال النور كل غرفة، كانت تثير إلى شيء وتثئ الثئ كلمة كانت تبدو أنها تنفجر في

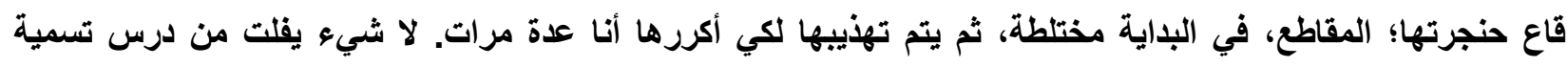
الأثياء ذلك الذي كان يشتمل على البضائع والمتطقات الثخصية: أوعية البورسلان، ووسائد مطرزة بالزخارف العربية، وأواني كريستال صغيرة تحتوي على الكافور والجاوي، ومخادع، ونجف من لبات كروية من زجاج حليبي، ومراوح

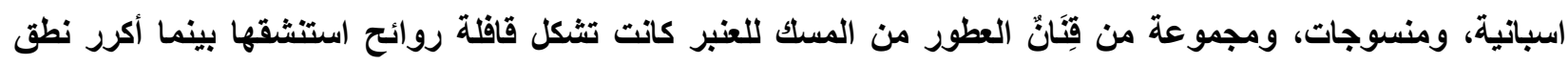

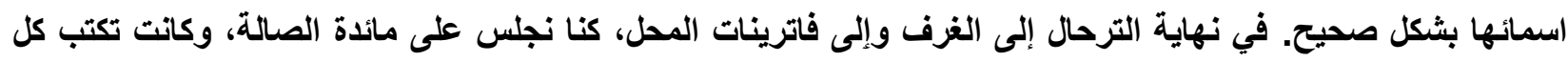
كلمة، وتثير إلى كتابة أحرف الأبجدية في بادية الكلمة ووسطها ونهايتها. كنت أنسخ كل شيء، وائه وأجتها للكتابة من اليمين

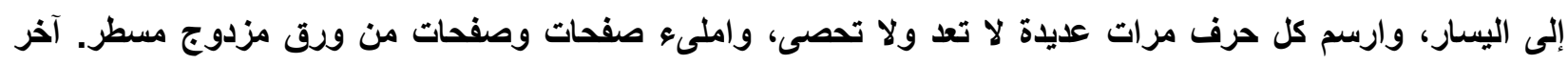

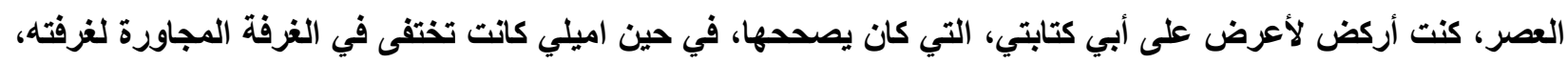

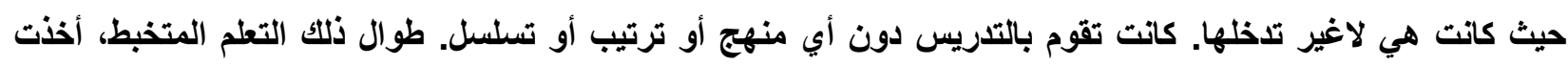

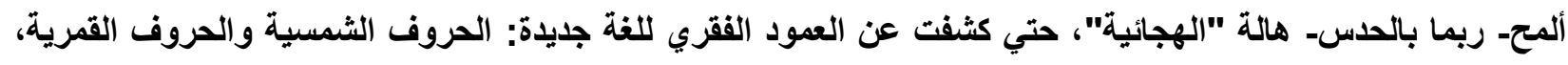

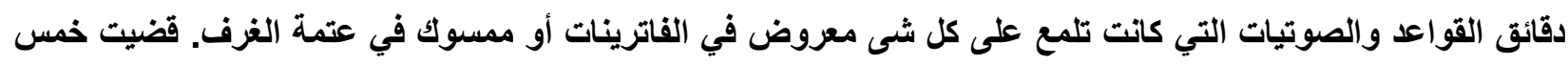

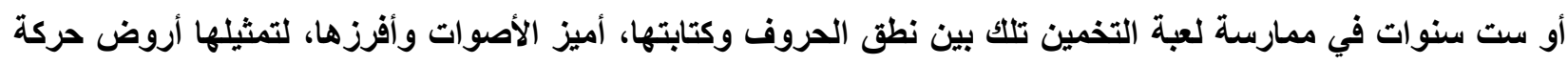

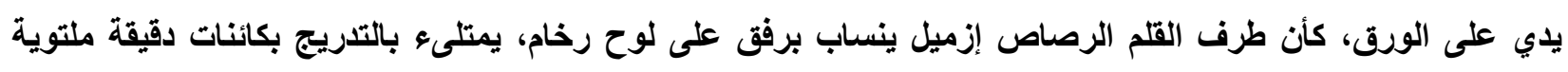
وملولبة تثف عن شكل الحزونيات والمناقيش والسيوف العربية، وثدي وحيد؛ كان اللسان ـ عند الاتصال بظهر الأسنان، وبمساعدة تثنجة - يطلق من الثفاه شبه المنفرجة سمكة فينيقية.

منذ صغري كنت أتعايش بلغة في المدرسة وفي شوارع المدينة، وبلغة أخرى في دوًار "الباريسية". وفي بعض الأحيان كان

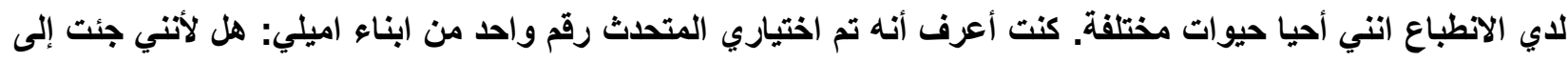

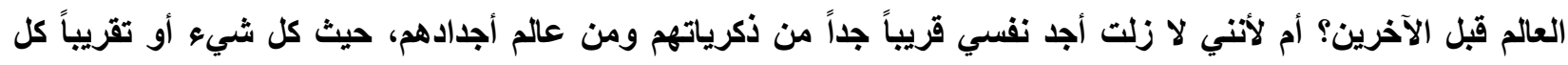

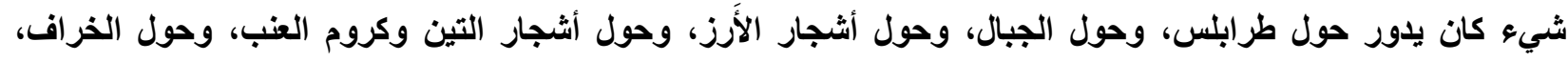

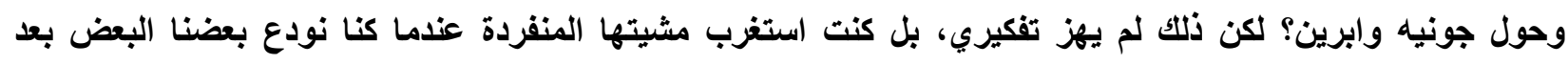

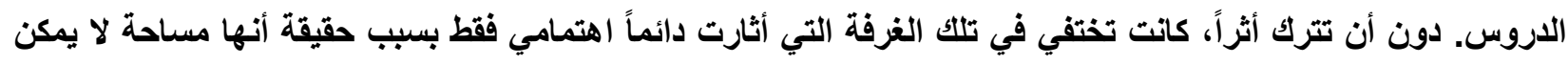

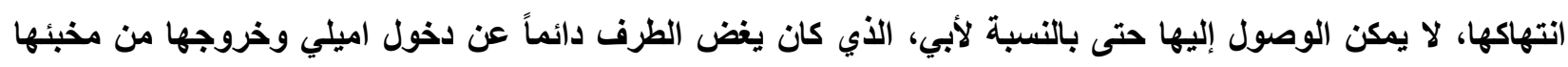

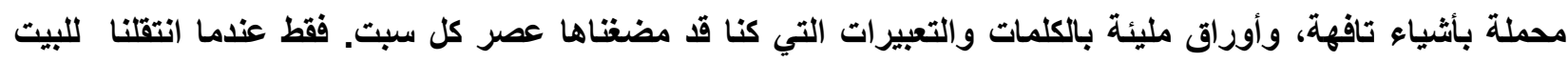

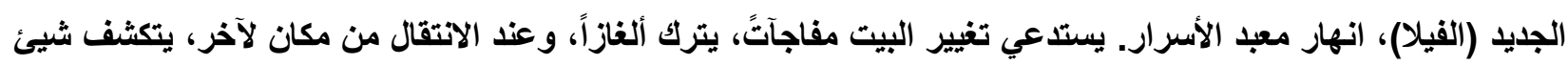

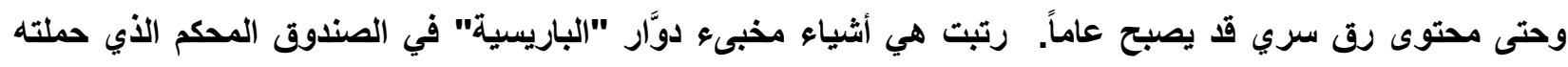

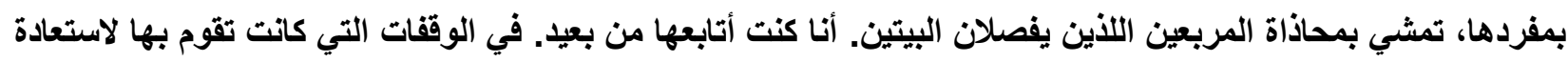

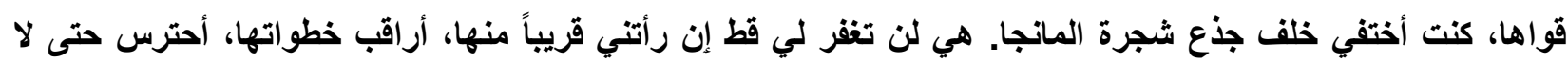


تتعثر وتقع في عالمها المحفوظ في الصندوق. عند دخول البيت الجديد، أخذت أفكر بشكل ملح: أين علها أمي قد وضعت الكتلة الثقيلة، الممتلئة بالمتعلقات التي لا يمكن الوصول إليها، والأسرار القديمة؟ الجئه

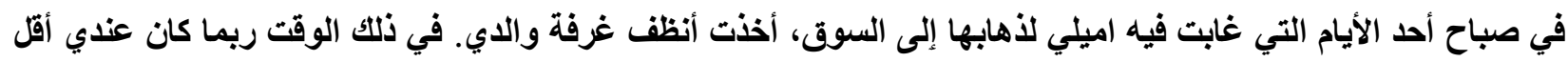
من عثرين عاماً وأذكر أن البيت كان شاسعاً بحق وحقيقي. كنا حينثذ أربعة أثثقاء، وأراحت الأسرة المساحة الواسعة للفيلا

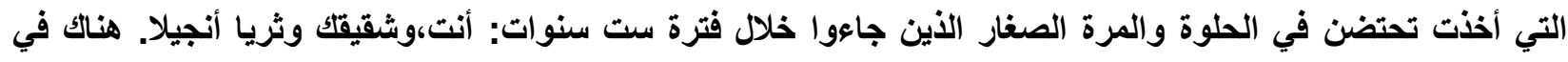
غرفة والايي قلبت كل شىء رأساً على عقب، أفتش في الأماكن التي حيث نظن أنتا سنجد دائماً مفتاحاً: في فتحات النوافن،

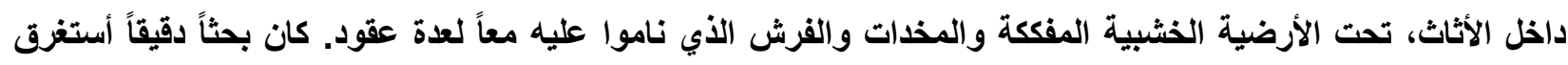

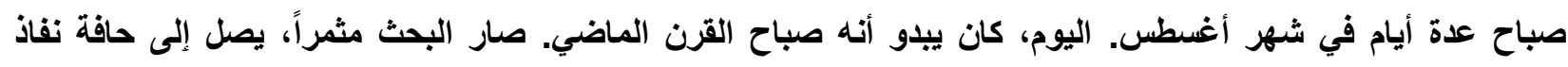
الصبر، أخذت أهز بعض الأثياء وأقلبها، مثل قطعة خثب الأرز اللبناني على شكل شريحة مخروطية. كان الجزء البان البارز

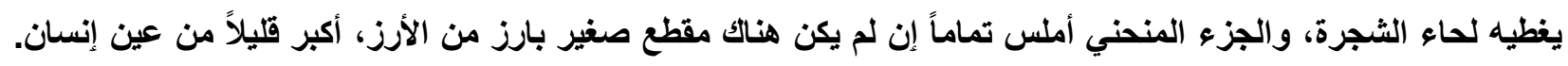

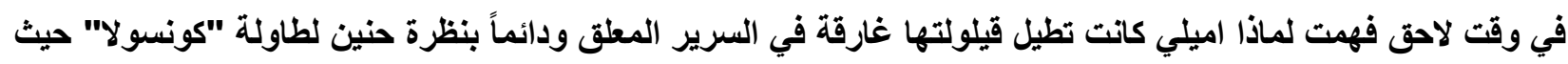

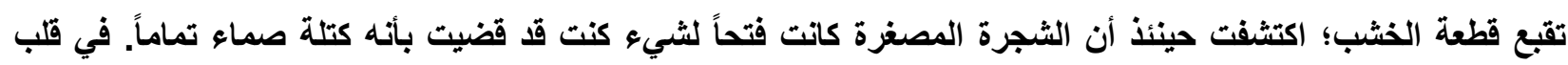

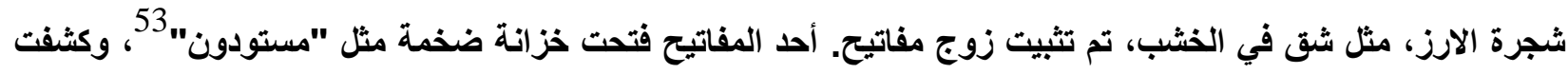

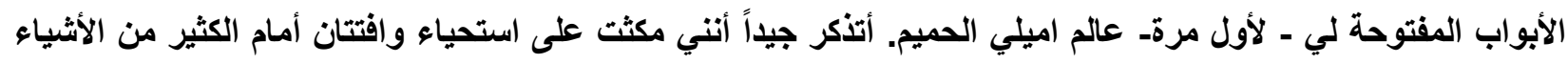

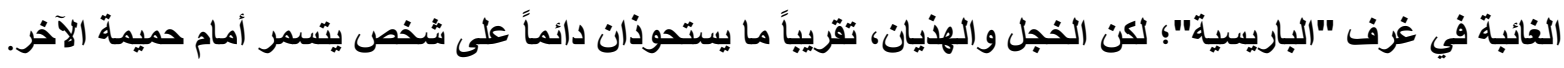

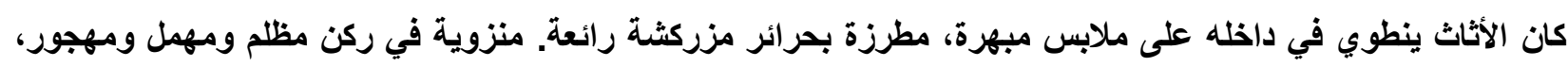

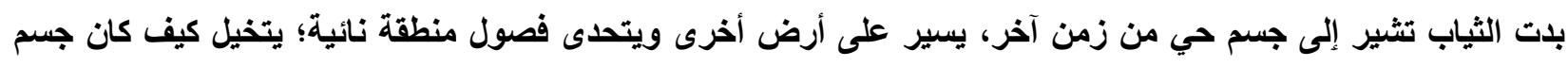
اميلي يظيه هذا الثوب الغريب، الذي كنت ألمح جزء منه في ركن مظل من الخزانة؛ كنت أتخيل مثاهد متناثرة من

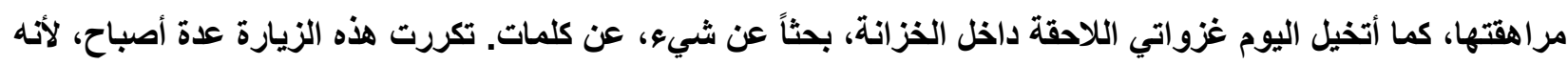

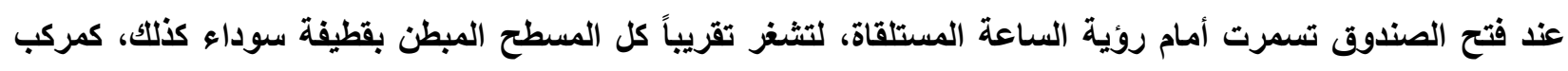

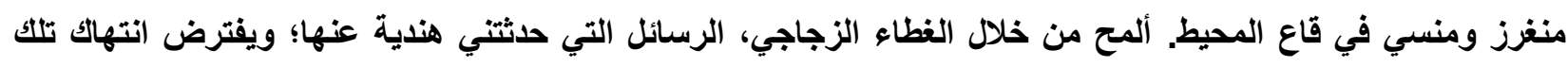

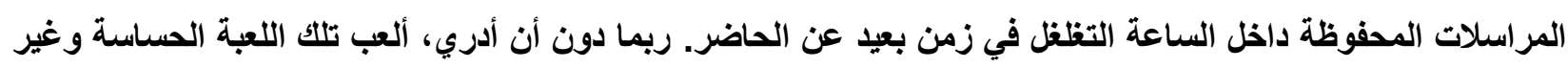

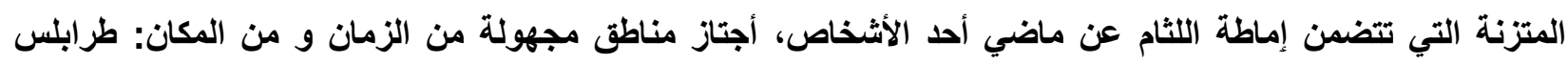

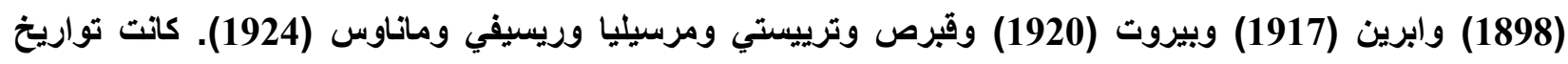

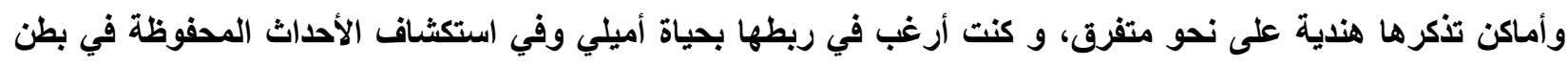

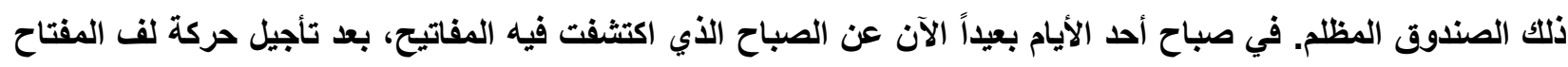
الأصغر عدة مرات، ومن تمحيص النظر في السطح الزجاجي المستوي، أتلمس بعيني زوايا العتمة، قررت فئح فئح النطاء

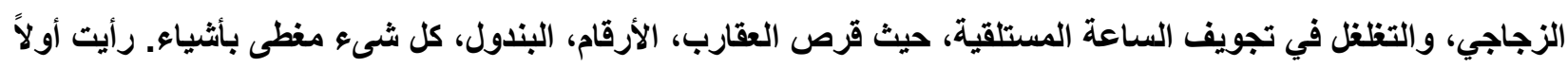

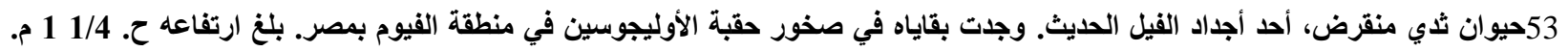

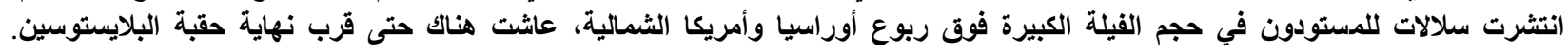


السوارين الذهبيين، حلقتين رفيعتين، مربوطتين بعقد تقريباً غير مرئية؛ ليصح القول، لم تكن عقداً أو رابطتات تجعل من السوارين سواراً واحداً؛ بالنسبة لي، كاتت نوع من التشابك السحري، تمفصل لا يمكن تفسيره، عند تحسسه، يستدعي فضولاً ورعباً. في أحد أيام الماضي، لابد أنك تتبهت للسوار الذي يلف ساعد اميلي كوشم ذهبي؛ في الحقيقة كان مكون من

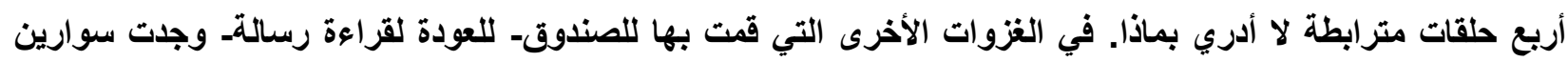
آخرين، مثل ظهور حلقة جديدة على جسم ثعبان. تأخرت بعض الوقت كي أربط عدد الأساور بعدد ابناء اميلي. لم أكتشف أبداً من أين تظهر تلك الحلقات الرفيعة التي تتو الد بثكل خفي في فراش الساعة. لم أجد أي ذكراً لها في الرسائل، وتماسكت عدة مرات كي لا أسأل اميلي عن أصل السوار؛ ذلك التظلي النهائي عن السؤال أقتعني كليةً أن هناك أسراراً قوية أو ألغازاً لا يمكن حلها، يحملها الإنسان معه حتى الموت. عندما ولد أخي الأصغر، عادت الأساور الأربعة تخص جسد اميلي. في تلكات الفترة أنا كنت قد فتثت بالفعل في زوايا الصندوق والساعة المغلق عليها هناك: رأيت الثوب الأبيض ملطخ بالعفن والبقع الصفراء وشوائب رطوبة وعلامات الهجر. لم أجرؤ قط على لمس ذلتك التونيك الكتاني ولا الهالة المطوية. هذا يسترخي على تلك، وكلاهما مطويان بعناية، كظل وجه ومحيط جسم يسندها قرص الساعة. لم يتم لمسهما من فترة طويلة، لأنه فضلاً عن البقع والعفن، خيوط لا نهاية لها تثكل نسيج كثيف وسميك، تتزايد بالتاكيد كل يوم؛ ربما هذه العلامات من البقاء والهجر، من البعد والذفاء، حالت بيني وبين تحريك الأقمشة التي أرتدتها اميلي لفترة قصيرة في ابرين. ذلك المقطع من التهائ

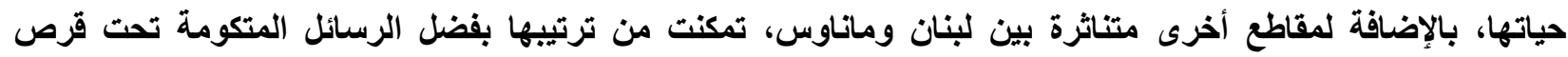
البندول، في منتهيات الصندوق الخشبي. كانت قراعة الخطوط الصغيرة عملاً طاحناً بالنسبة لي. المراسلة مكتوبة باللغة العربية الفصحى، وموقعة دائماً بحرفي "ث. بي."، تجتاز سنوات وسنوات، تتقطعها أحياناً فترات فاصلة من بضعة أثشه. في مناطق الصمت تلك،، كان ينقطع حبل تفكيري وأواجه صعوبات في الكتابة، أتجاوز جملاً كاملة واققز على الكلمات، مثل قاريء محاصر بشفرات لا يمكن فكها،

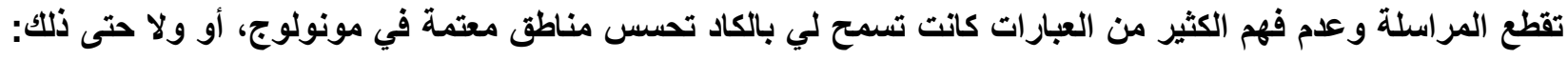

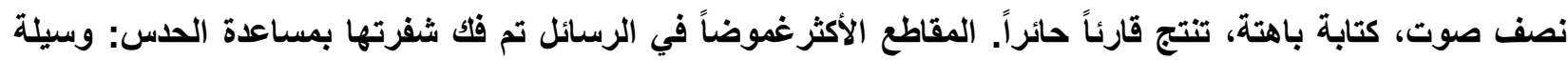
ممكنة للخروج من مأزق القراءة المنقطة بتمتمات، دون مساعدة القاموس، وإن تصفح بعشوائية دفاتر التدوينات التي كانت

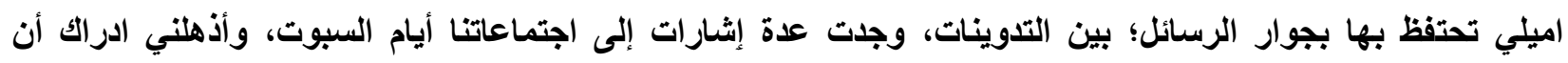
الكلمات المجمعة كاتت وفيرة. كما أنني وجلت كذلك بعض الصلوات باللغة الفرنسية، وكاتت صلوات "السلام عليك يا مريم" التئ

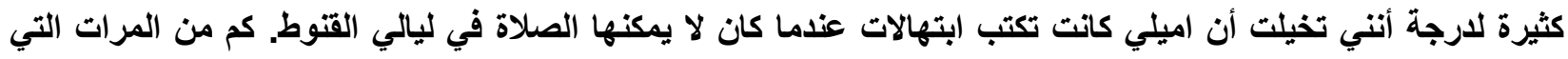

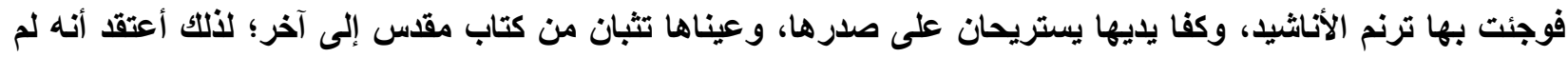

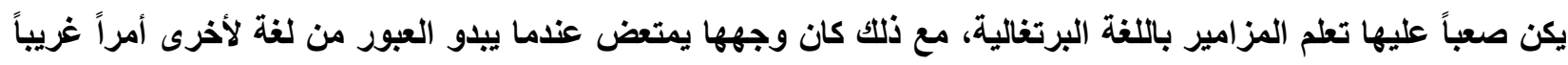

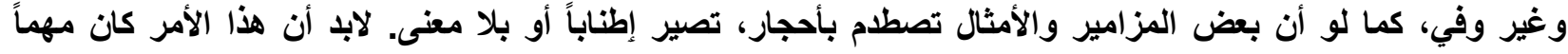
لاميلي، لأن "قُ. بي." أورد ذ ذكره في عدة رسائل وكتب مقطع من الكتاب المقدس باللغة الفرنسية، يطلب من الصديقة

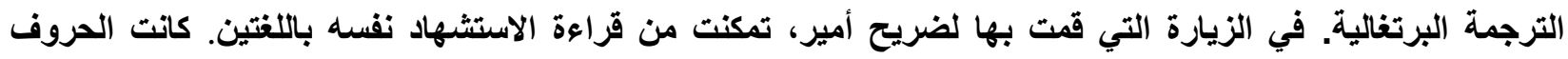
منقوشة على شاهد القبر، تحت صورة فوتوغرافية لجسد شاب. فيراب. 
نادراً ما كان يتم ذكر اسم أمير أثناء تناول الطعام أو في المحادثات الحية على وقع أنفاس الثيشة وجرعات العرق وضربات الطاولة. كان أبناء اميلي ممنوعين من المشاركة في هذه الاجتماعات التي كاتت تخرق المساء وتنتهي عند فناء النافورة، الذي يضيئه نور ضارب للزرقة. كاتت لحظة تتسع فيها الموضوعات المغربلة والمستهلكة والغزيرة بالفعل للمناجاة والتأوهات، تتظلفها في بعض الأحيان لغة العصافير، وتتخللها شهقات التعجب والاستشهاد باسم الله. كان كما لو كان الصباح - مثل دخيل يسكت أصوات المساء الدافئة - يبدد الجو الاحتفالي، ويفتر الإيماءات الأكثر انفعالاً، يدعوهم إلى العمل الأي يبدأ مع الفجر. لكن في بعض اجتماعات أيام الجمعة، استثراف الصباح لا يصرفهم. كنت استيقظ بصرخات مؤلمة، وآهات رهيبة، وضجيج ركض وصخب تهليل الذين يثاهدون معاناة الخراف التي كانت لايها أسماء وكانت تغذيها يد اميلي. هرولت حتي غرفة والديي، من خلال فتحات النوافذ الكبيرة، أرى الدم المتدفق من رقبة الحيوان، يفقو على عينيه اللتين لا تزالان مفتوحتين، يتخلل فروته البيضاء والمجعدة. في ذلك الجسد المتألم، ينتشر لون حائر يذكر ببقعة شفقية في وسط الهـ الفناء الذي يتعرض لشروق الصباح. يتم انتظار تصفية دمه حتى آخر قطرة، ليجري تقطيع الحيوان وبتر أوصاله وتقسيمه، كانت اميلي تنتزع احشائه بيديها وتفصل على لوحة الأرز ما يمكن الاستفادة به منها، وتلقي بالأجزاء التي ينفر

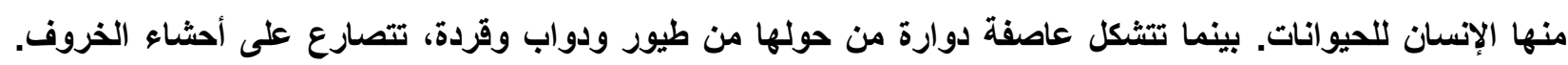
تغسل الكبدة وتنظقها، وتتبلها بالملح والقلفل الأسود والنعناع. يتم رفع لوحات الطاولة من المائدة، ويذكر لاعب ما أن عليه الاور القادم في إلقاء النرد. كاتت اميلي تساعد اناستاسيا سوكوهو في إحضار رقائق مخبوزات الجلاش، المطوي مثل أوشحة الحرير، وسلة بها التين الثوكي والجنيَيَو 54 والبيرِبا55 والأناناس والبطيخ؛ وطواجن من الفخار المحروق، بين خشخاش مقطوف من الحديقة، كانت هنائ عناقيد بيتومبا56، وحبات الماراكويا57 البرية وفواكه أخرى شديدة الحمضية، كانت عند لمسها اللسان تحدث قشعريرة في الجسم وامتعاض الوجه. لكن وجه اناستاسيا سوكوهو كان يمتعض لسبب آخر: بعد ترتيب المائدة، كاتت تلجأ إلى إحدى حجرات البيت، كي لا تشاهد منظر نهم الطعام. في وسط فناء تضيئه الثمس الإستوائية، كان الرجال والنساء يكررون عادة غذائية قديمة من آلاف السنين وهي أكل كبدة الخروف النيئة باليدين. لم أكن أشاهد من غرفة الوالدين الإين طقسياً بربرياً أو التضحية بحيوان، بل أمر جليد مدهش وحفل عجيب يتناقض كثيراً مع الإيقاع المعتاد للبيت.

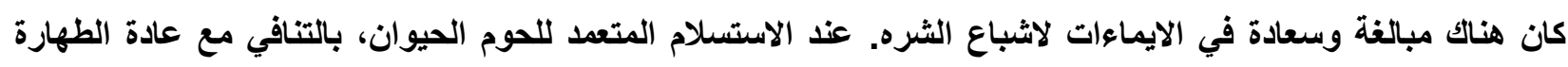
اليومية، كانت اليدين تحمل إلى الفم قطعة كبدة طازجة، ويتم تداول الخبز من يد إلى يد، تمزقه أصابع ملطخة بزيت الزيتون والزعتر. كان هناك من يغني آخر الأغنيات الأيأعة في القاهرة، ومن ينثد قصيدة صوفية أو حكاية للعطار 58، أو يستحضر نشيد الزهر، والقرنفل، والمرجان ويختتم بذكر نشيد الياسمين، أن فقدان الأمل خطأ. يشيدون بالتوابل، وحلويات الهريسة بعين الجمل والعسل الأبيض، مربى بتلات الورد، التي كنا نطيل في شمها قبل أن نجربها. كان البعض يخشى ألا تتم دعوته

الجنييَيو: ثمرة أستوائية ضاربة للون البني.

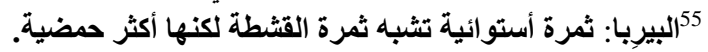

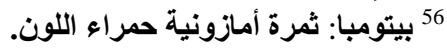

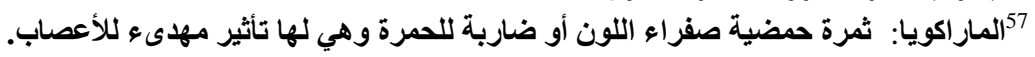

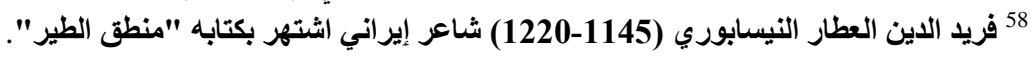


لعشاء السبت ـ عندما يتم اعداد فخذة اللحم الضأن المشوي مع التمر- ينتظرون بفارغ الصبر لحظة الوداع لكي يتلو أبي العبارة التي بها يأذن الله لهم بفتح أبواب البيت لعثاء الغد. استمرت هذه الإجتماعات في البيت الجديد، لكن كان في "الباريسية" أن تتبهت لوجودها. الحديث فقط باللغة العربية، بإستثناء تحيات أحد المارة المعروفين، أو زيارة أحد الجيران، وبعضهم أجاتب، مثل أسرة أميريكو من "بوفوا دي فارزيم"، أو آل بن عامو من المغرب، والصبي جوستاف دورنر من هامبورج؛ كلهم أصدقاء حميميون لاميلي، وهذا الأخير فضلاً عن كونه صديقاً، كان من المقربين لي.

كان من خلال دورنز أن عرفت أول مكتبة في حياتي. كاتت مكونة من ثمانية جدران من الكتب، التي لحسن حظي تعرفت عليها فقط في وقت لاحق بعد عدة سنوات، لأنه لو كان الأمر عكس ذللك لكنت قد منعت نفسي للأبد من عادة القراعة التي كنت اكتسبها آنذاك. كان صوته غليظ مثل اسمه، ويتكلم برتغالية منمقة، تقريباً بدون لكنة، فكان يترك أهل اللغة في قلق لارجة أنه فقط لا يتم خلطه بأمازوني بسبب مظهره الخارجي: كان أطول وأكثر ألمان المدينة شقراً، وكان يرتدى بطريقة

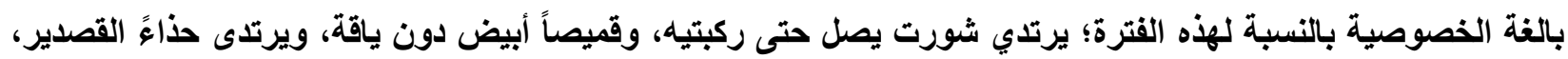
دون رباط ولا جورب. جراب أسود معلق في حزام ويتدلى من خصره، من كانوا يرونه من بعيد يظنون أنه زمزمية كولدير أو قارورة، ويبدون إعجابهم بمهارته في سحب الكاميرا "هاسلبلاد" من الجراب وركضه خلف مشهد في الثوارع، داخل البيوت والكنائس، في الميناء، في الميادين وفي وسط النهر. علاوة على ذلك كان يمتلك ذاكرة يحسد عليها: ماضي بأكمله معاش مع أهالي المدينة وفي بلده، كان ينبض من خلال الكلام الدافق بصوت راعد، يجلد صمت الحي بأكمله. لكن الذاكرة كان يتم استدعائها بواسطة الصور؛ كان يدعو نفسه أنه مطارد بلا هوادة "للحظات مشرقة من الطبيعة البشرية ولمناظر فريدة من الطبيعة الأمازونية". لبعض الوقت هو كان يكرس نفسه لإعداد "أرشيف بمفاجآت من الحياة": صور لشخص وحيد ، لشحاذ، لصياد سمك، لهنود يعيشون في مكان قريب من هنا، لعصافير وزهور وحشود.

عرفت أنت وأخوك دورنر. لا أعرف إن كنت حينذ تلميذته، لكنك تعرفين كم كان مشتتاً. كان أحياناً يتهيأ لي أن تشتته كان وسيلة للفرار من الناس ومن الواقع المحيط به؛ كل ما كان يلمحه كانت تصوره عدسة الكاميرا؛ كنت أقول له، ساخراً، أن عدسات هاسل تثكل من نظارته، ومن حدقتيه الزرقاتين نظاماً بصرياً وحداً. لم تزعجه قط تلك المقارنات الثاذة للغاية؛ أجابني أنه عند النظر لكاميرا هاسل كان يرى وجهه. وفي بعض الليالي الحارة، عند العودة من التمشية في المدينة المهجورة، كان يتسمر أمام وجه آخر مضيء وملتصق بعدة زجاجية، حيث تستلقي الكاميرا هاسيل خلال المساء، يستيقظ في وقت مبكر على دفء لمبة، حرارة صناعية لدرء الفطريات الخفيفة، للحفاظ على صفاء العدسة، وليكون النظر من خلال عدسة الكاميرا واضحاً : انتصاراً للشفافية. صور دورنر أمير في وسط منصة ميدان البوليس. كاتت آخر صورة لأمير، قليلاً قبل مشيته الانفرادية التي انتهت به لقلب الميناء ولقاع النهر. قصة هذه الصورة حكاها لي دورنر بنفسه، بعدها بسنوات، بكلمات موزونة حتى لا يكثف حقيقة رهيبة كنت قد حلتها بالفعل عند قراعة خطابات فيرجيني بولاد. كاتت الصورة تحكي ما لا يقدر دورنر على قوله: الوجه 
المشدود لجسم يسير في دوائر أو على غير هلى؛ إحدى يدي أمير كاتت تختفي في جيب بنطلونه، ويده الأخرى القوية تملس على زهرة أوركيديا جد نادرة لارجة أن دورنر لم لم يهتم بقتوط صديقاه

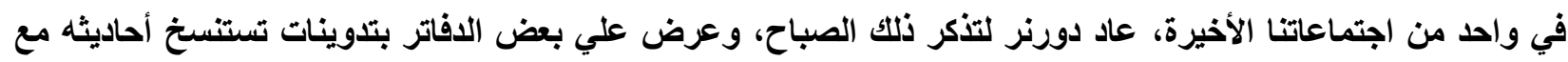
ابي" 
"في تلكل الفترة كنت أعيش بكاميرا هاسيلبلاد وكنت أجيد استعمال كاميرا فيديو باتيه. كنت أصور كل شىع في هذه المدينة

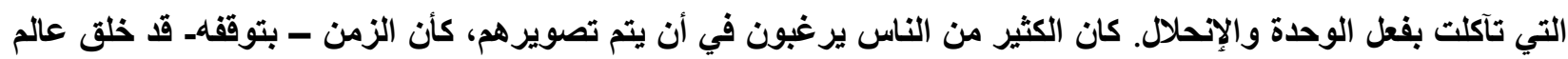
أثباح صغير، عالم صور، فقد وهجه، يأوي أسر بأكملها كاتت تمر أمام الكاميرا، مجتمعة في حدائق الفيلات أو على ظهز عوابر المحيطات التي كانت ترسو في ميناء ماناوس. في الصباح الذي لمحت فيه أمير على منصة الميدان، كنت متوجهاً إلى مسكن إحدى تلكت العائلات التي كانت قادرة في بداية القرن على تغيير مزاج ومصير كل سكان المدينة وأعالي النهر، لأنها كانت تسيطر على الملاحة النهرية وتجارة المواد الغذائية. كان على أن أعد ألبوم بورتريهات لتلك العائلة، بل وصباحاً، كان على تحميض الأفلام وتكبير الصور التي توثق لأقلى

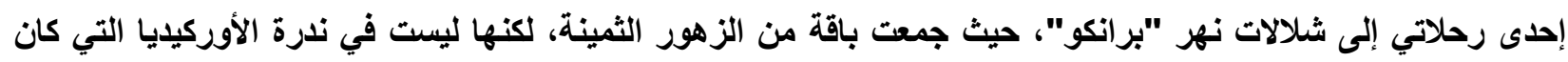

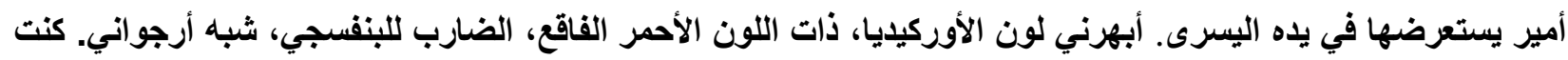

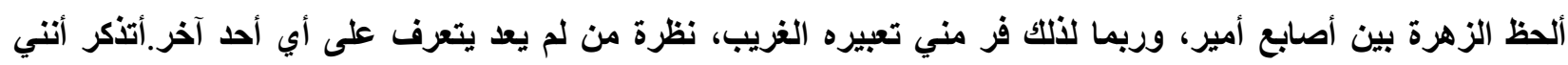
دعوته للغذاء في المطعم الفرنسي؛ صدر عذه بالكاد صوت مكتوم، كلمات مبهمة فسرتها على أنها رفض للاعوة؛؛ للكني

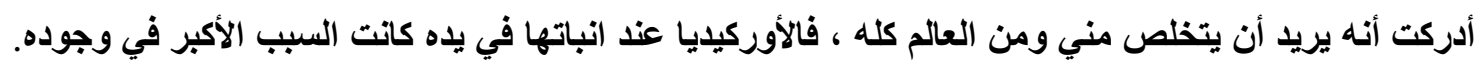

بينما كنت أعد صور عائلة أهلير، كنت أفكر في الحوارات التي دارت مع أمير، كان يتكلم لغة غريبة

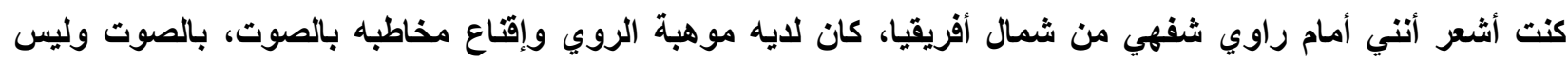

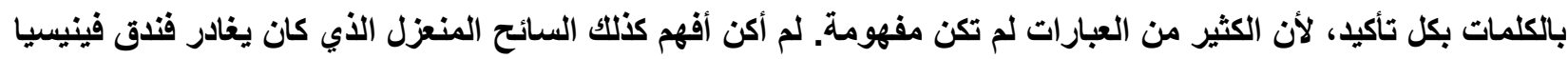

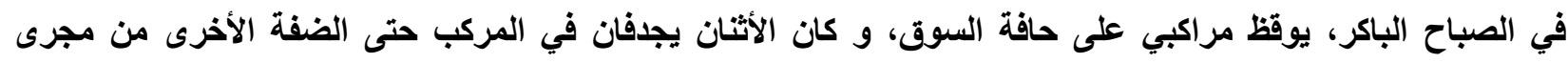

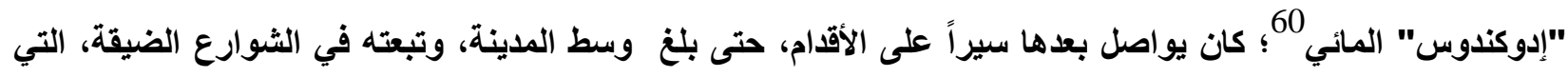
تفصل بينها صفوف من الفيلات المتهالكة.لا، لم يكن أمير مثل غيره من المهاجرين، لم يكن ينغس في الأحراش يجابه

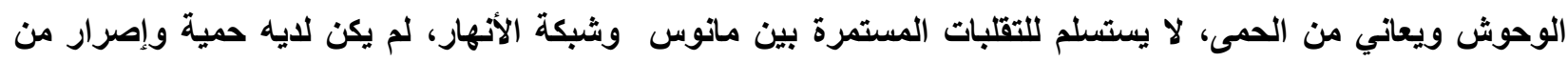

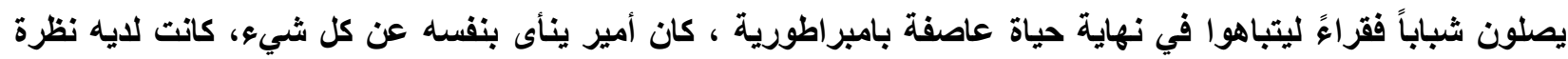

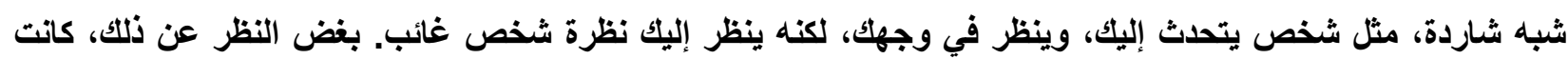

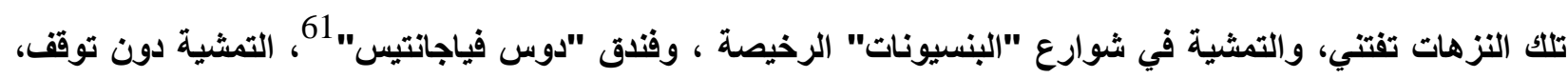

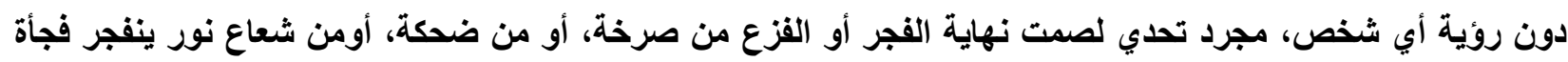

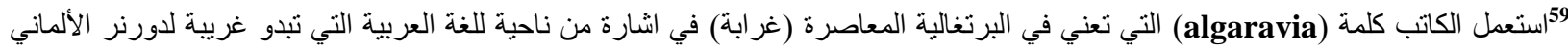

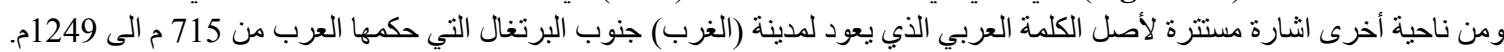

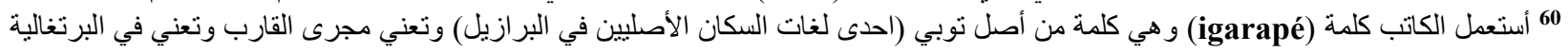


على نافذة غرفة. كانت حياة أمير تقتصر على تلك النزهات الصباحية: بعد عبور المجرى المائي، التمشية حتى ميدان "دون بيلرو الثاني"، وشارع المتاجر الكبيرة62، هـهـ الصواري، وظهورالسفن والمداخن العالية، وصفارة "هيلدبراند" المدوية، التي كانت تجلب مسافرين من ليفربول، ليشويش وجزر ماديرا، وربما عرف أمير وجهة السفينة: نيويورك ، لوس

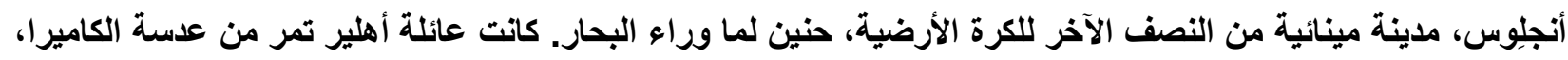

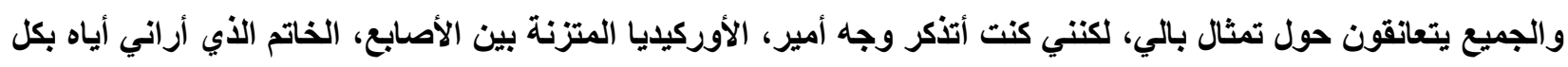

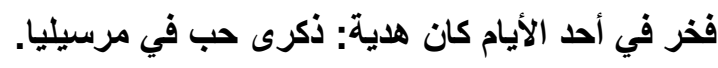

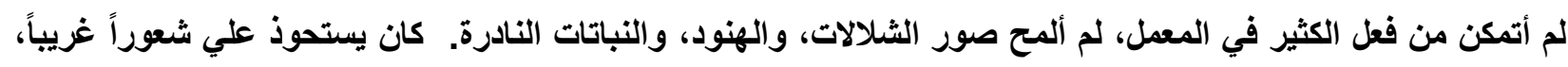

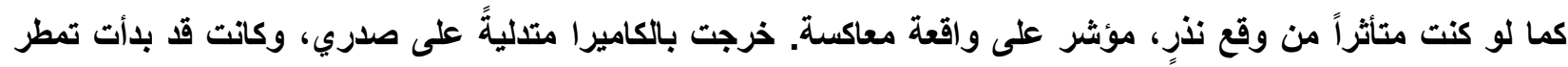

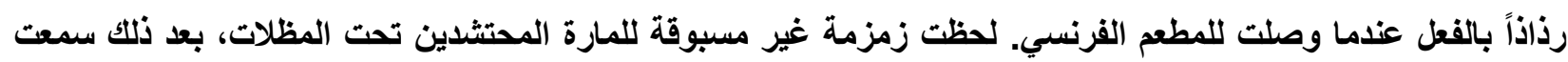
هاير أجراس المطافىء يقطع صمت منتصف النهار. كان هناك تكلس في المطعم، جلست على المائدة الوحيدة الثناغرة

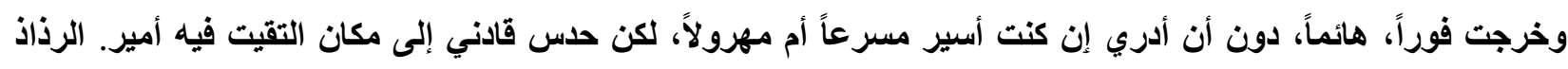

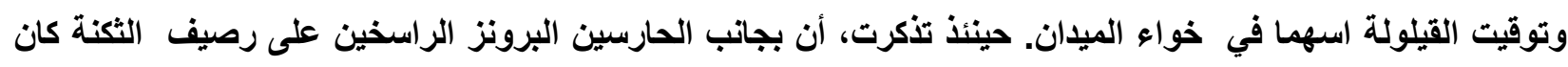

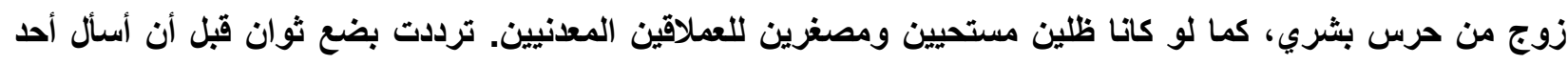

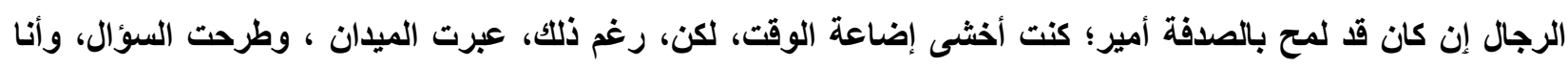

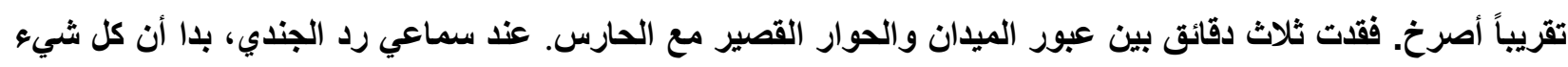

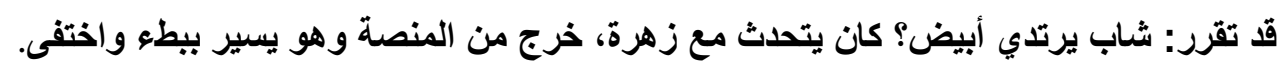

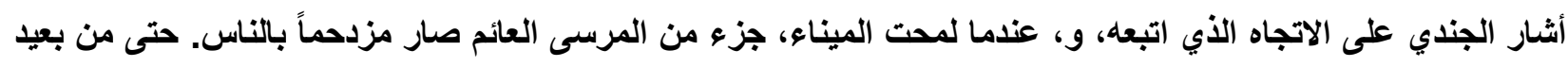

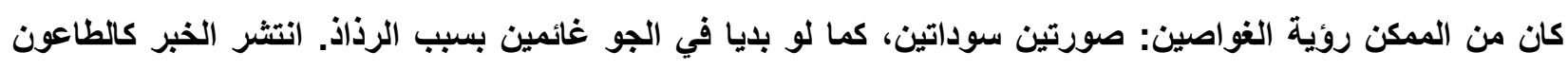

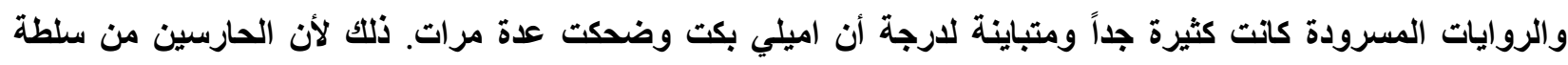

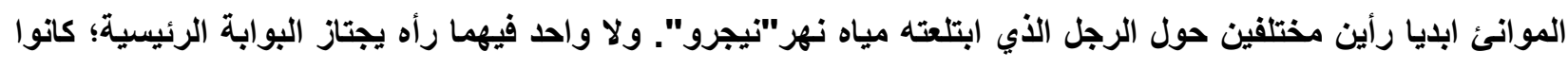

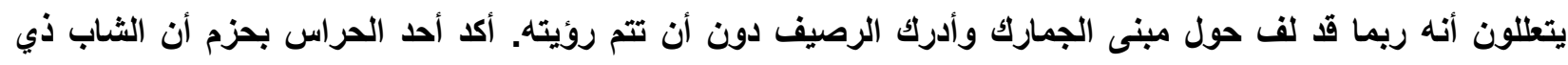

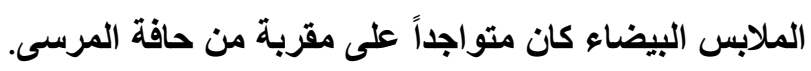

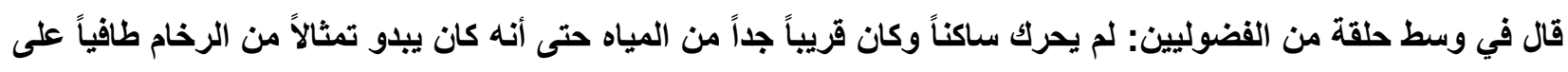

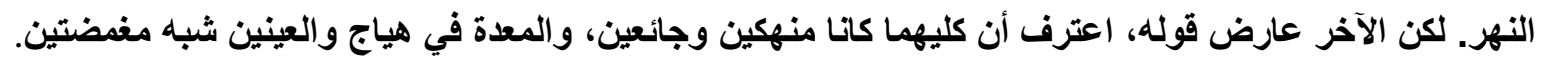

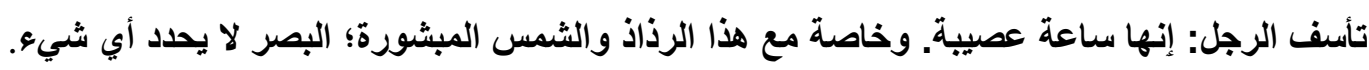

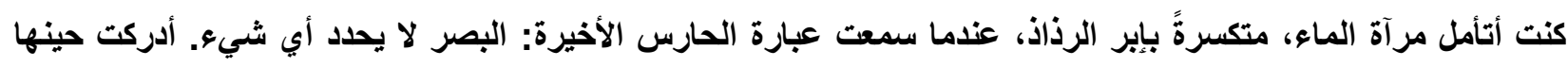

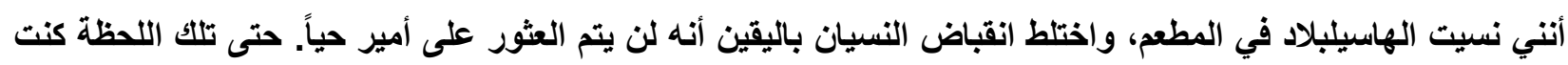

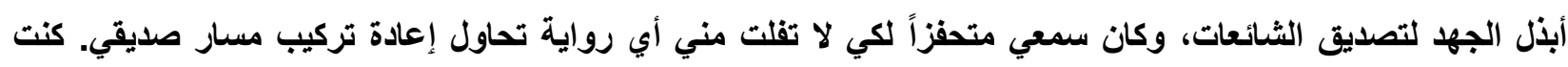

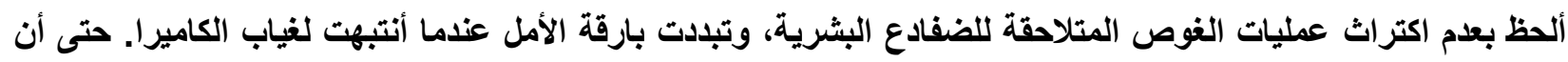


اميلي وخاللك اميليو لاحظا ارتياعي. احستت في الوجه خواءً، كما لو كانا قـ عصبا عيناي، شعور بفقدان الجسد للوعي، شيء مشابه لدوار يعقبه عمى مفاجىء. بعد ذلك أنصت لاميلي تقول شيء ما بجها جهيد؛ كررت "ماذا؟" "ماذا؟" "لأين؟" وتبدو الكلمات مثل مطرقات أو إنذارات متكونة من نكرارات: نبرة الصوت نفسها والكلمات نفسها التي كاتت ستتفجر حتماً إلى شظايا أصوات. دون أن تلتفت لأي أحد، ويداها ملتصقة بأذنيها ورأسها متدلية للخلف، انفكت في الكلام وفجأة انفرطت لتره الحلقة البثرية التي كاتت تحيط بالحارسين وتركزت الأبصار عليها. أخذ الفضوليون الذين كانوا يثرثرون يتهامسون وصمتوا مرة واحدة، واطلقت اميلي صيحة غير مفهومة للجميع، إلا لثقيقها، الذي حاول أن يسكنها بين ذراعيه؛ لكن ايماءة أفضت إلى سلسلة من الإلتواعات وكانت الأجساد تبدو أنها تتعارك مع شيء خارجها. بقيا هكذا لعدة ثوان. بعد ذلك إلك انحنت اميلي لاحتواء حركات الجسد، وثبتت في وضع حلزوني، شبه مستلقية على المنصة المعدنية. ترددت الصفارة الأولى، ضعيفةً، تقريباً غير محسوسة؛ من كانوا بجوار اميلي لم يسمعوا الصفارة بسبب الآهات. نظرت لحافة الرصيف وركزت في الضفادع البشرية: الوجوه مرئية من خلال زجاج القناع الأسود، الذراع يشير للأفق؛ وحينها ذلك الصوت الذي ينساب سلساً، مثل صوت ناي، كان يبدو أنه يأتي من صورة ظلية ضاربة للبياض، محيطها غير محدد، شبه ملتصقة بخط الغاب، يغوص من آن لآخر في الأثعة الثمسية، يتلاثى في سديم الرذاذ ويعاود الظهور مثل جسم منير، هدف ربما ساكن أو متحرك ببطىء لارجة إن كان من المستحيل معرفة إن يتوجه نحونا أو أنه يبتعد عن الميناء. مرئية من بعيد، منغمسة في النور والماء، كانت الصورة الظلية تثبه لوحة حية، صورة زيتية تتحرك بخفة: الأفق المائي، سديمي ومشمس في الوقت نفسه، وتألق شريحة بيضاء ومنحنية، مثل قوس نور بين السماء والماء. مر ذلك الظهور في الأفق دون أن يدركه من كانوا حولي. ظلت اميلي وشقيقها متشرنقين، جسد يستر الآخر، في كل لحظة يتم سماع همس يكسر الصمت، بينما الناس تنظر بحيرة للجسدين اللذين أنساهم الغريق، البحث عنه، سبب تواجدنا هناك. كنت ابتعد عن الرصيف، أسير على جسر عائم عندما سمت الصفارة، الأصفى، كما لو أن الصوت، غريباً على الصورة الظلية البيضاء، قد خرج من السرديم:صفير من الفضاء. في الطريق بين الميناء والمطعم كان على أن أتجب بعض الأثخاص الذين كانوا قد عرفوا النبأ. هذه هي الحياة في الأقاليم: صديقاً للك يختفي، فيستحوذ مناخ مميت فوراً على المدينة؛ تبزغ أولاً التساؤلات الطائشة؛ بعد ذلك، التلميحات اللئيمة والمهووسة عن حياة الضحية، عندما لم نصدق بعد فقدان الصديق، وتتأرجح مشاعرنا بين الأمل في البقاء على قيد الحياة

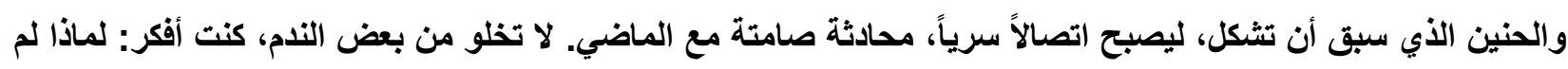

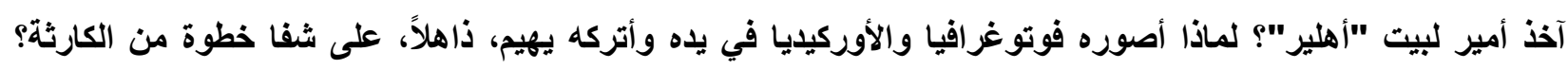
صور أمير تلك، لا تزال حية في ذاكرتي، مسجلة في فيلم الكاميرا التي نسيتها في "لافيل دي باريس". كان صاحب المطعم قد حفظ الهاسيلبلاد وانتظرني بفارغ الصبر. بوجه مرعوب وصوت طرق، اطلق وابل من الأسئلة، خلط عدة فرضيات، ذاكراً غرق، انفجار، مشاهد كارثة. كان يتكلم ويتساءل في الوقت نفسه، لكن كل شيء ذهب أدراج الرياح لأني حلت العقدة من لساني بالإجابة بلغتي الأم. أدركت فقط أنتي كنت أتكلم بالألمانية عندما أخذني المارسيلي من ذراعي وصاح: حضرتك تكلم نفسك، كان عذده حق؛ أول مرة أكلم نفسي بلغتي. سلوك مماثل سيتكرر فقط في الليالي التالية، في أحلام متناثرة ومخيفة.

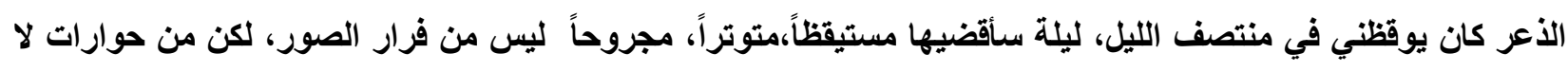

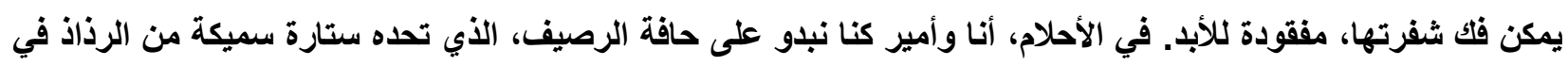


لحظة من يوم يتسم بالصمت. ما كنا نقوله لبعضنا البعض لم يكن يقتصر على مجرد النقاش، وإنما هو مزيج من الألفاز، وأصوات تتردد، فقد كنا نلجأ للغتنا الأم، التي بالنسبة للآخرين ليست إلا أصوات بلا معنى، كلمات تمر من خلال منشور غير مرئي لحناً صافياً تتجرعه الرياح الدافئة، أصوتاً منطلةًً في الجو يفجرها السرديم: رذاذاً متصلاً في الأحلام. في محاولة يائسة لفهم الآخر، كفهمك لنفسك؟ كان قلق سوء الفهم يوقظني في ذعر، ويقية الليل كنت أسحب نفسي ثقيلاً وبطيئاً، بينما كنت أهرع بعبارات من الحلم لإستعاداة الحوارات وتذكر الأصوات. بعد أسبوعين من اختفاء أمير، ندرت الأحلام وآخر حلم تزامن مع نبأ أنهم كانوا قد وجدوا جثته في قاع المجرى المائي حيث كان المحبون يتنزهون في مراكب صغيرة أو زوارق مغطاة بمظلة بيضاء لتلطيف الجو الحار. كان من وجد الجثة لوباتو، هندي كان والدك قد عرفه قبل زاوجه من اميلي. لم يكن والدك بعيدا عن أهالي الأرض، لكنه كان دائماً مشبعاً بلامبالاة جليدية مع الجميع،بما في ذلك مع الأبناء، كما تعرف. كان يولي اهتمامه بمراجعة البضائع، وتلميع الفاترينات والصلاة بشكل خاص في إحدى أغوار حراء، عند تخوم البيت أو

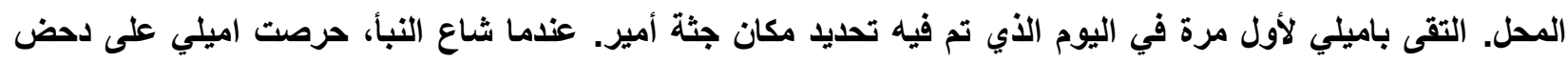
فكرة أن الجثة جثة شقيقها. ظلت لمدة يومين تناقش بحة رأي طبي شرعي، مستاءةً من المنهج المستخدم في التعرف لهاع على الجثة. تساءلت اميلي ساخطة قبل حتى أن ترى الجثة: الأطباء هنا بالكاد يتمكنون من تثخيص الأحياء، كيف يستطيعون التعرف على شخص بفحص طقم أسنان هيكل عظمي؟ في الحقيقة، كان سخط امك مبالغاً وتقريبا غير معقول، ففي حيذها كانت بقايا الجثة تثي ببعض الملامح المميزة بالقطع

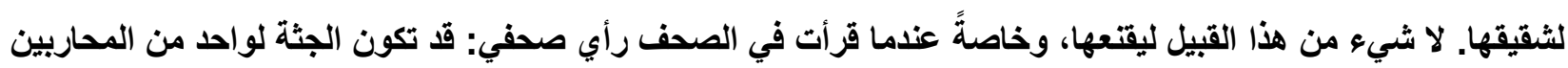
الكثيرين الذين سقطوا في اشتباك دموي في 1910 بين قوات حكومية وقوات فيدرالية. كان يُقرَأ في "جورنال الكوميرسيو":" في موسم الجزر لكل واحد جثة تطفو وتعكر مزاج الرأي العام". بدأ نشر ذلك المقال الخيالي في تعزيز الشكوك عندما جاء والدك باليل دامغ يبلد كافة التكهنات التي تحيط بهوية الضحية، وختم على نحو ما مصير حياة اميلي العاطفية. أتذكر تماماً علامات الجدية التي ارتسمت على وجهه، وجسمه الممشوق، المنحني قليلاً، وكفي يديه المنبسطتين والهائلتين. دخل البيت حيث كانت تعيش فيه اميلي مع شقيق آخر، قدم نفسه بالعربية وبالبرتغالية، ولم يرد الجلوس لأنه كان مستعجلاً. أنا والزيارات الآخرى تركناهما على راحتهما. أعتقد أن لا أحد تصور ما كان سيقوله. سحب من جيبه علبة صغيرة ووضعها في كف يده اليمنى وقدمها لاميلي. وفي اللحظة نفسها التي فتح فيها فمه للكلام، غطت اميلي وجهها بيديها وتلعثمت بكلمات لم أفهمها، كما لم أفهم كذلك الكلمات القليلة التي نطقها والدك، بصوت غليظ لازمه حتى وفاته.

بعد دفن أمير بشهور قليلة تزوجا. قد يكون من غير المجدي الإشارة إلى أن والدك لم يرافق النعش، كما لم يرافقه بعدها بعدة سنوات، مع وفاة جديك، بعيداً عن هنا، على شاطىع البحر. في تلك الفترة كنت أغيب عن المدينة، لكن عرفت أن كلاهما رحلا عن هذا العالم عندما كنت لاتزال رضيعاً؛ لابد أنك قد استغربت، ظلت بضعة أسابيع بدون أميلي. رفض والدك السفر إلى "ريسيفي"، كي لا يترك "الباريسية" في أيدي الغرباء، لكنه سمح لزوجته بالسفر على متن عابرة محيطات لزيارة قبري والديها، اللذان كانا قد توفيا في اليوم نفسه. ذهب أميليو معها. في ماناوس كان يصطحب كل منهما الآخر في لي لري 
زيارة المقابر والكنيسة. لم يسألاني قط إن كنت متليناً، لكن ربما كانا مستائين سراً من هذا الأجنبي الذي كان يعيش في

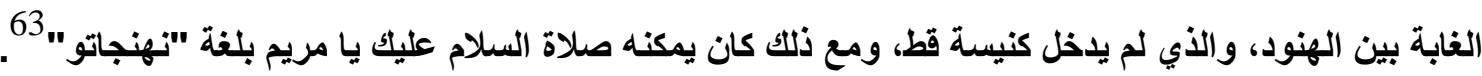
كاتت اميلي وزوجها يطبقان فروض الدين بحماسة. قبل الزواج اتفقا على أن يحترم كل واحد منهما دين الآخر، وأن للأولاد حرية اختيار أي من الاياتتين يتبعان أو لا يتبعان أي دين.

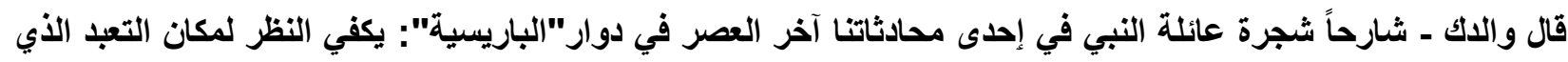

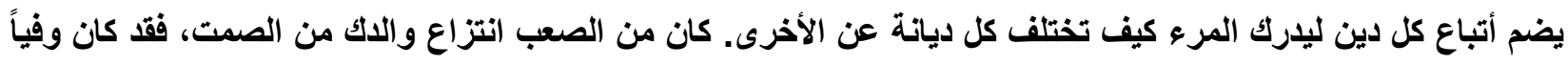

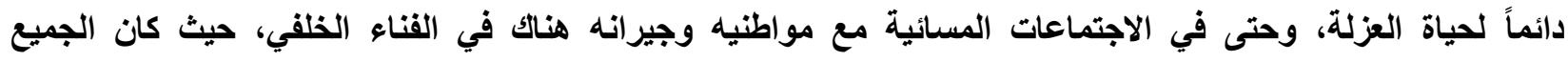
يثرثرون، بينما أبوك مطرقاً، ربما يفكر في التعاسة الهائلة التي كانت تحل بمن لا يتمكنون من البقاء بمفردهم. المضيف

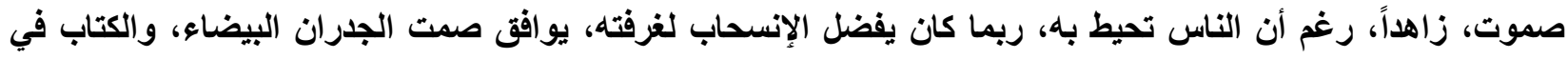
قبضته، يتابع سقوط سلطان كان يحكم مدينة أندلسية، يتعقب خطاه من خلال المخادع السبع في قلعة منيعة، حتى يلمس الأس حائط المخدع الأخير حيث كان مدوناً المصير المشئوم للغازي.

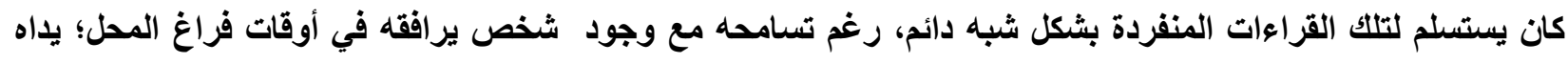

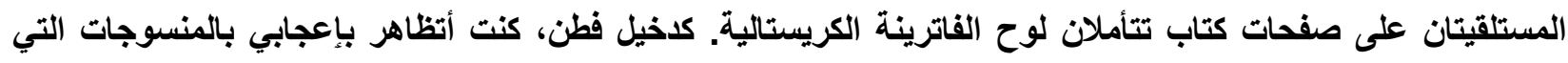

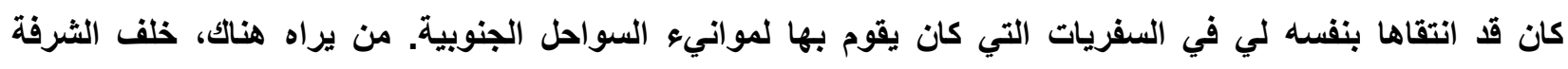
الضخمة، وعيناه مركزتان في صفحات كتاب سميك، قد يفترض أن هناك هوة بالفعل بين ذلك الرجل والفاترينات. وهوة

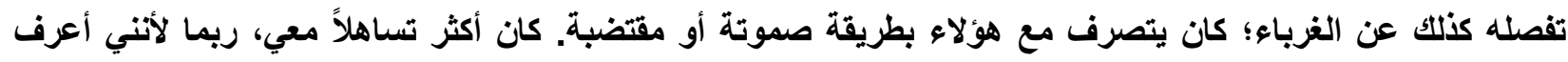

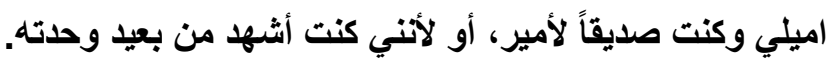

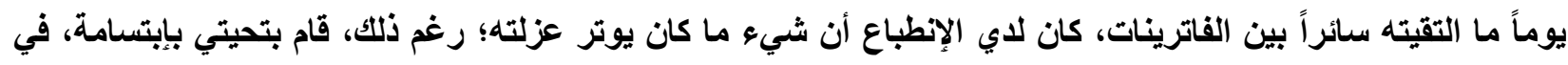
الوقت نفسه الذي كان يبسط فيه خريطة مرسومة لحوض الأمازون. سألته دون أن أنقص أو أزيد في الكلام إن كان يسير بانير بحثاً عن الفردوس، عن فردوسٍ ما أرضي.

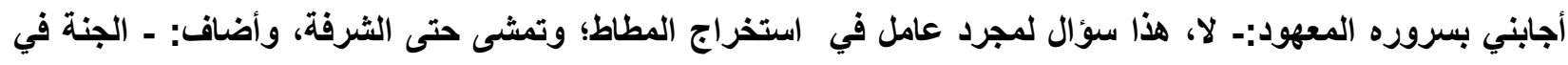
هذا العالم توجد على ظهور الخيل الصهباء، في صفحات بعض الكتب وبين نهدي أمرأة.

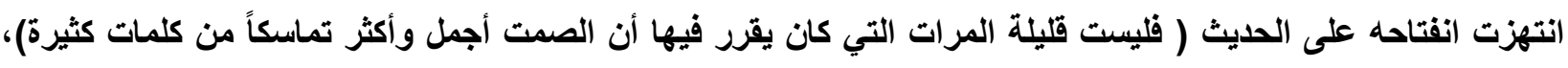
وحاولت أن أجس نبضه حول شيء من الماضي. سكت للحظة، دون أن يتوقف عن إمرار أصابعه على شبكة لامتنهاية

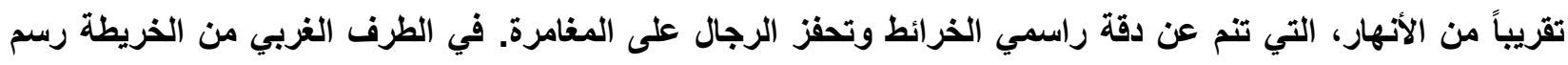

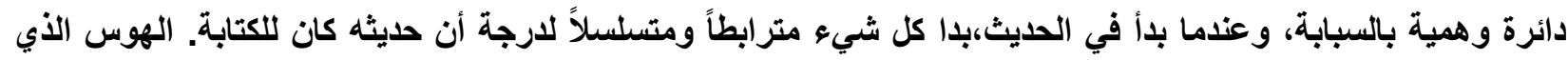

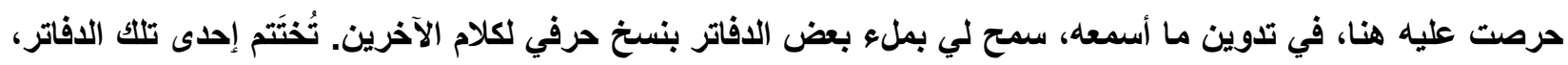

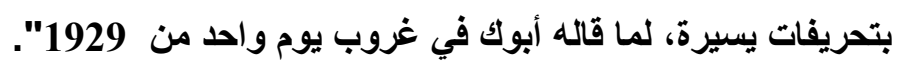


"أنتهت الرحلة في مكان سيكون من قبيل المبالغة أن نطلق عليه مدينة. على سبيل التوافق أو الراحة، أصر سكانه على

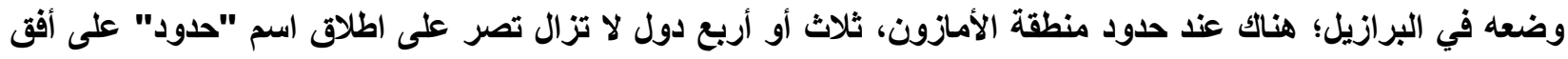

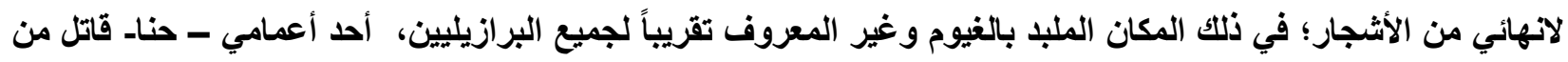

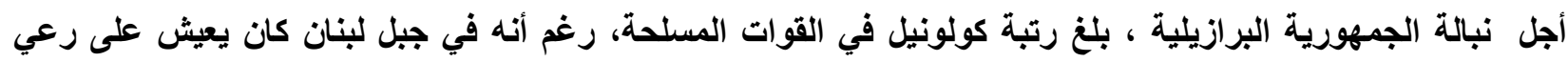
الأغنام وتجارة الفاكهة في المدن الساحلية جنوب لبنان؛ لم نعرف أباً سبب مجيئه إلى البرازيل، لكن عندما كنا نقرأ

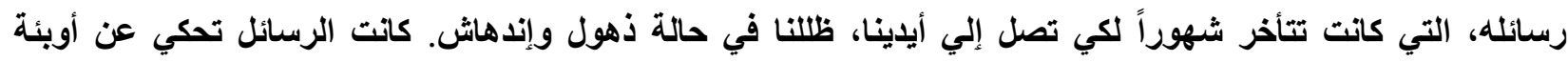
مدمرة، وحشية يرتكبها بحرفية رجال يعبدون القمر، معارك لا تحصى مصبوغة بألوان الثنقى، رجال يستطييون لحوم أثباههم كاستطعامهم ذيل الخروف، وقصور ذات حدائق رائعة، مجززة بجدران مائلة ومتقطعة بنوافن مقوسة تتجه إلى بالى مغرب الثمس، حيث يستقر قمر شهر رمضان. كاتت الرسائل تحكي كنلك عن المخاطر التي واجهوها: أنهار عريضة السطح لارجة أنها كاتت تبدو مرآة لامتناهية؛ والجلد القزحي اللون لأحد الزواحف التي أيقظته بلمعانها الحاد عندما كان

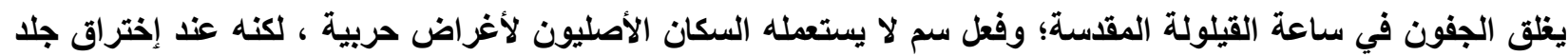
شخص ما، تنيمه، فتتسبب في كوابيس رهيبة، كاتت مجموع أتعس اللحظات الأتعس في حياة أي إنسان. بعد أحد عشر عاماً، ربما في عام 1914 ، ارسل حنا صورتين له لنا، ملتصقتين على الجانب الأمامي والخلفي لورق كرتون مستطيل الثكل، داخل المظروف كاتت هناك فقط بطاقة مكتوب عليها: "بين صفحتي الكرتون هناك صورة أخرى؛ لكن هذه الصورة يتم رؤيتها فقط عندما يصل القريب القادم هنا " .عند قراعة البطاقة، قرر والدي وهو في طريقه إلي،:

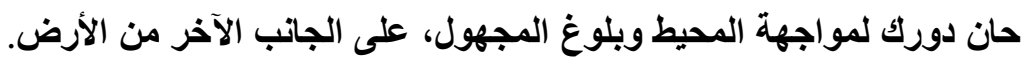

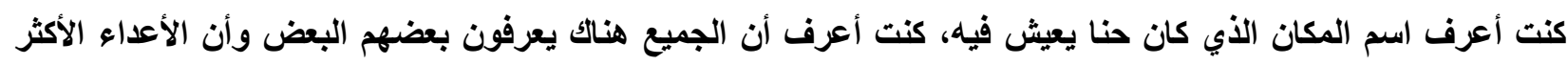
صلابة يتصادمون من وقت لآخر. كاتت الرحلة طويلة: أكثر من ثلاثة آلاف ميل تم ابحارها لعدة أسابيع؛ في بعض الليالي، أنا والمغامرون القلاثل المرافقون كنا نبلو الناجين الوحيدين من الكارثة. وأخيراً وصلنا إلى مدينة حنا ، في ليلة حارة

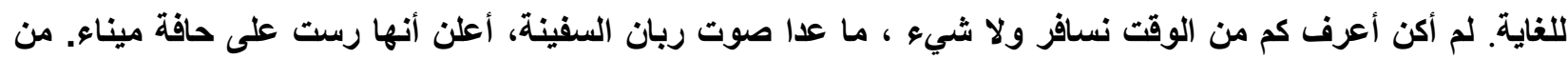

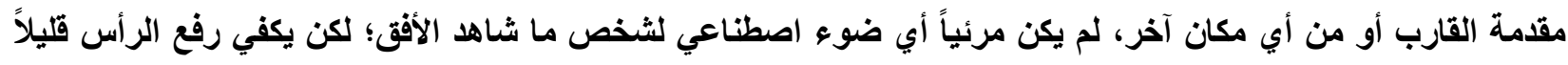
ليتوقف البصر عذد حفل نجوم تنعكس على سطح النهر، وتمتد على خطوهمي لا نهاية له بطول القارب؛ كان الظلام يحيلنا لوجود على الحدود بين الأرض والمياه هناك. أنتظرت بفارغ الصبر الفجر : الطبيعة هنا فضلاً عن أنها غامضة كانت منضبطة بثكل دائم في مواعيدها. في الساعة الخامسة كان كل شيء لا يزال صموتاً في هذا العالم اللامرئي، في دقائق معدودة طلع النور مثل وحي مفاجئ ، مختلطاً

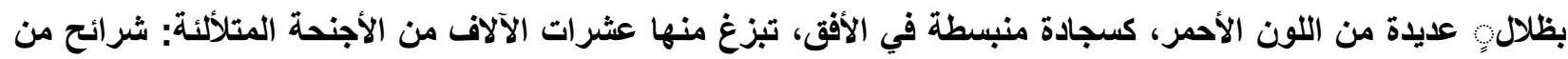
اللؤلؤ والياقوت؛ وخلال ذلك الفاصل الزمني القصير من الإضاوة الخافتة، رأيت شجرة ضخمة تمد جذورها وكأسها بإتجاه

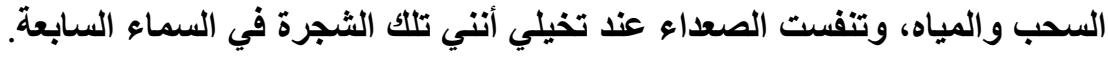


لا يزال الجميع من حولي نائمين، هكذا شاهدت وحدي ذلك الفجر، الذي لن يتكرر أبداً بالثدة نفسها. مع مرور الوقت، فهمت أن روئة منظر طبيعي فريد قد تغير مصير إنسان وتجطله أقل غرابة عن الأرض التي تطنتها قدمه لأول مرة.

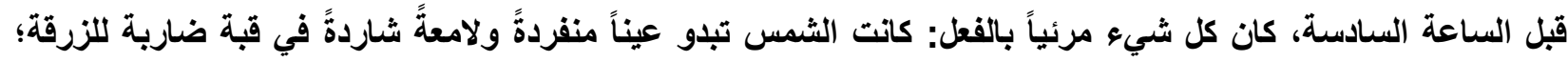
ويقعة داكنة ممتدة أمام القارب، ولدت المدينة. لم تكن أكبر من العديد من القرى المحفورة في أعماق الجبال في بلادي، لكن حقيقة أنها واقعة على أرض مستوية كانت تعزز تكرار البيوت الخثبية وتبالغ في سطوة المباني الحجرية: الكنيسة، السجن، فيلا أو أخرى بعيدة عن النهر؛ لا جدوى من التأكيد على أنه لم تكن هناك قصور؛ كانت هذه القصور جزء من فن فئل

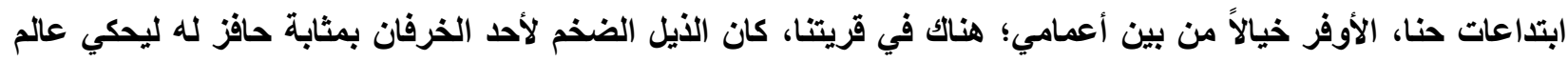

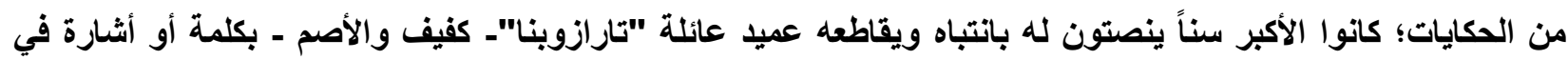
لحظات التردد، عندما يفلت منه شيئاً في الكلام. نزلت من القارب بواسطة لوح خثبي ضيق ومشيت بين الناس الذين كانوا ينتظرون بفارغ الصبر أخبار وأقارب وتوصيات؛

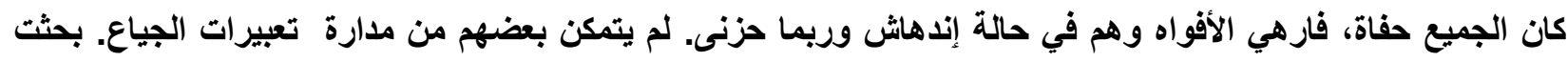

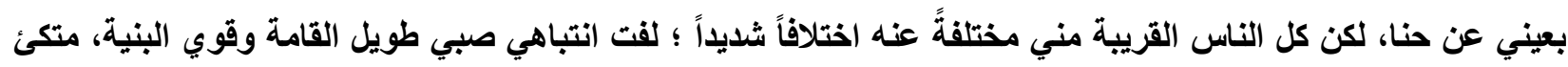

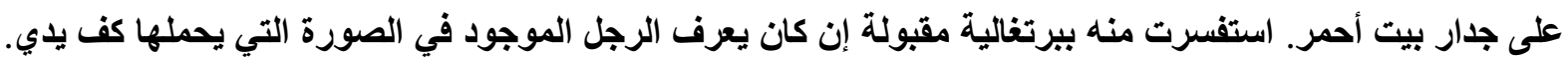

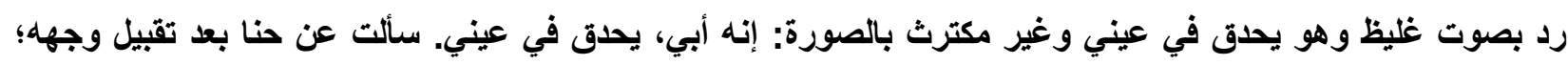

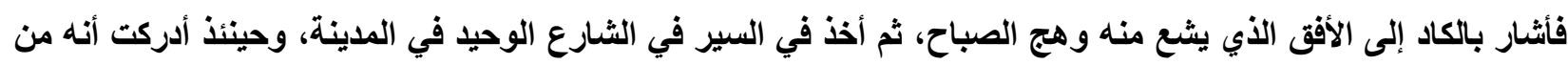

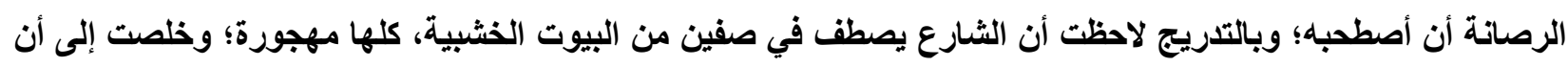

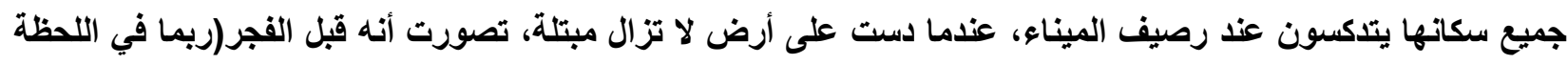

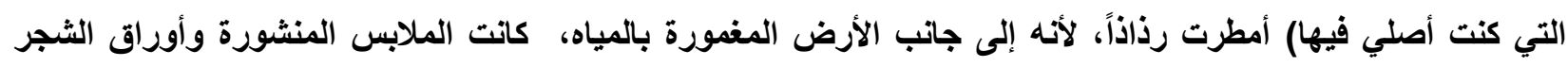

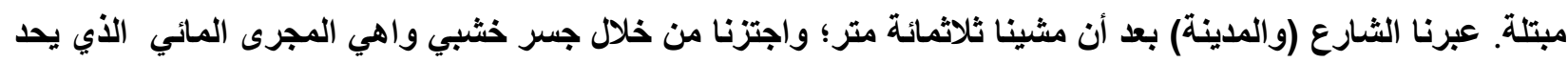
بين القرية والغابة. لم أتصور أبداً أن حنا سيعيش في الأدغال، كزاهل بين أثجار الأرز العتيقة في الجبال! لكن فكرت أن الوحدة ليست بالتأكيد

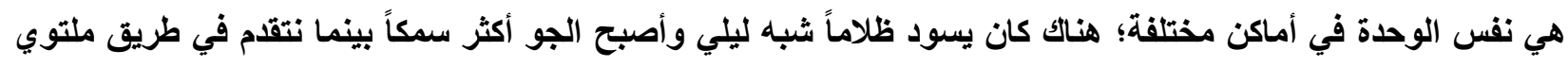

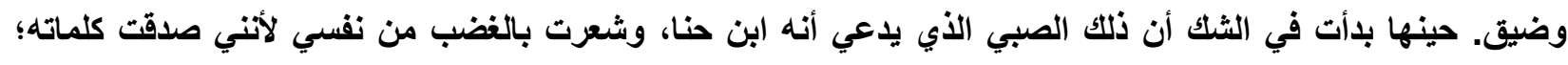

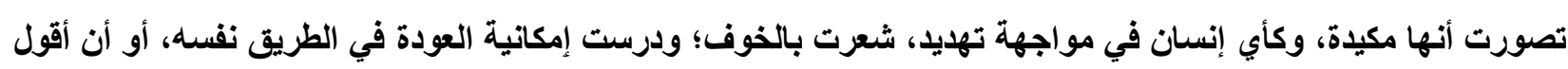

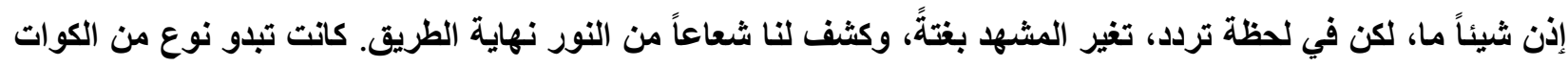

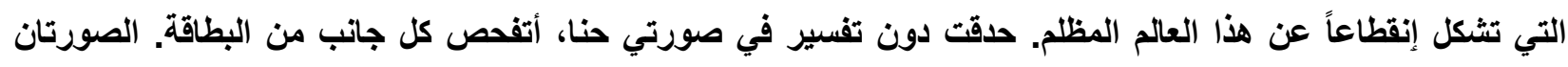

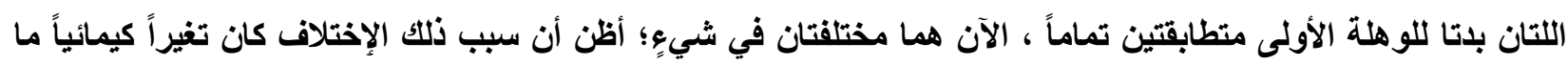

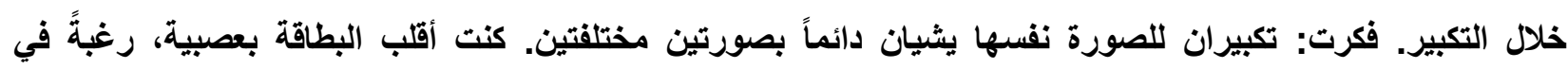

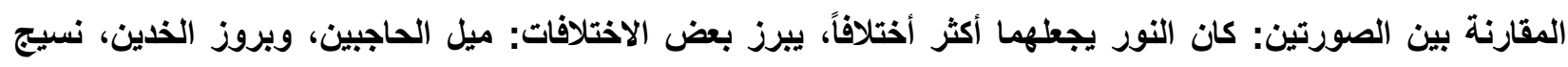
الثعر. جسد الصبي و هو يمشي بإتجاه النور شتت انتباهي. ذهبت لملتقاه، حتى بلغتا السطح المجرف: شرخ هائل من النائ الطمي المهروس كان يبعنا عن الغابة. 
دون أن يثير إلي، عرفت تحديد موقع مقبرة حنا: كانت الوحيدة الخالية من صليب وصور القديسين. حينها فقط تذكرت التحقق من الصورة الموجودة بين صفحتى البطاقة. كاتت صورة أخرى لحنا، وهو لا يزال شاباً، قبل رحيله، لكن بلت أيضاً صورة لأبنه. لم أرغب في معرفة كيف مات ومنى ـ بعد أن عاش بض السنوات في ذللك المكان، كان من الممكن أن

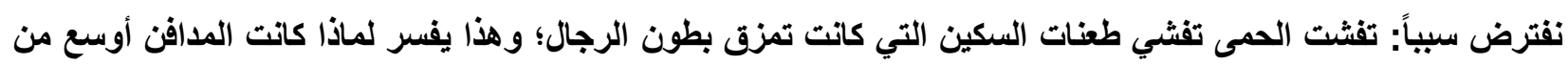
المدينة. لم أهتم كنلك بهوية والدة الصبي أو مصيرها؛ علمت من خلال أحد معارفي أنها كانت المرأة الأكثر بهاءً في المكان،

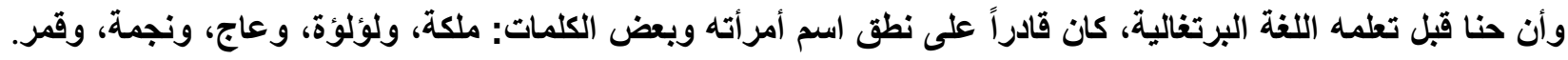

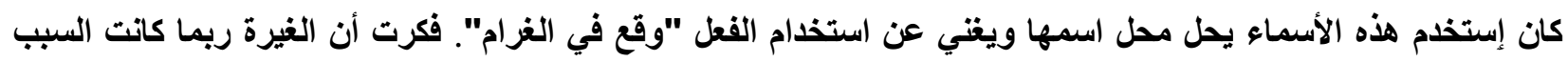
في نهايته؛ لكن على كل الأحوال، أبنه عند إلتقاء أمرأة سيثأر لأبيه. عثت بعض السنوات في القرية، عرفت أكثر الأنهار وعورة وسرعان ما تعلمت التجارة، بالإضافة للعمليات الأساسية،

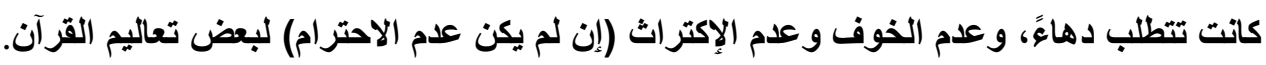

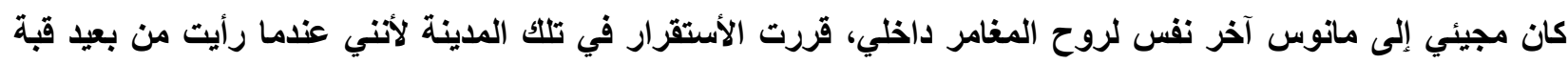
المسرح، تذكرت مسجداً لم أره في حياتي قط، لكن ورد في قصص كتب الطفولة وفي وصفٍٍ في أحد أحاديث بلادي.

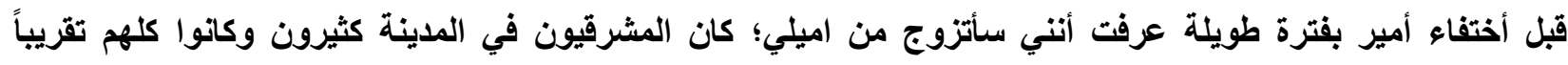

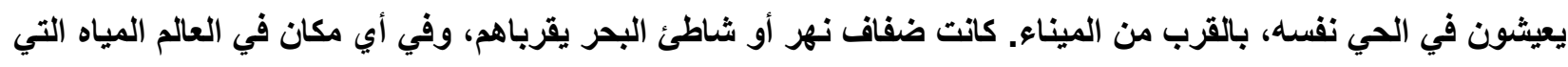

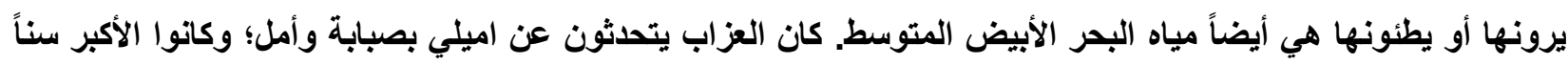

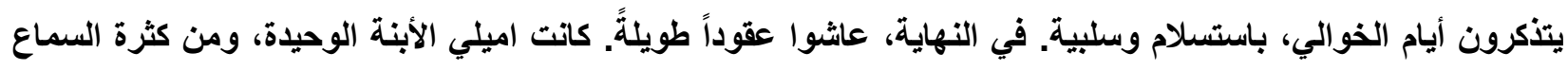
عنها، وقعت في غرامها." 
قائمة بشخصيات الرواية

أرميندا

ازمير الدا

أميز

اميلي

اميليو

اميليو

أناستاسيا سوكوهو

ثريا أنجيلا

حكيم

جوستاف دورنز

سارة بن عامو

سترابو

سمارة ديليا

سميرة

فاضل

فيرجينيا بولاد

لاوري

مدام فيردادي

مينطه

هندية كونسبساو

ياسمين

قائمة باسماء الأماكن في الرواية الأمازون

منزل "سوبر ادو"

"الباريسية"

مطع "لاقيل دي باريس"الواقع في شارع "أوسُو"

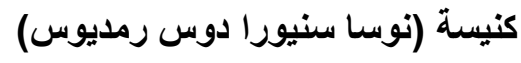




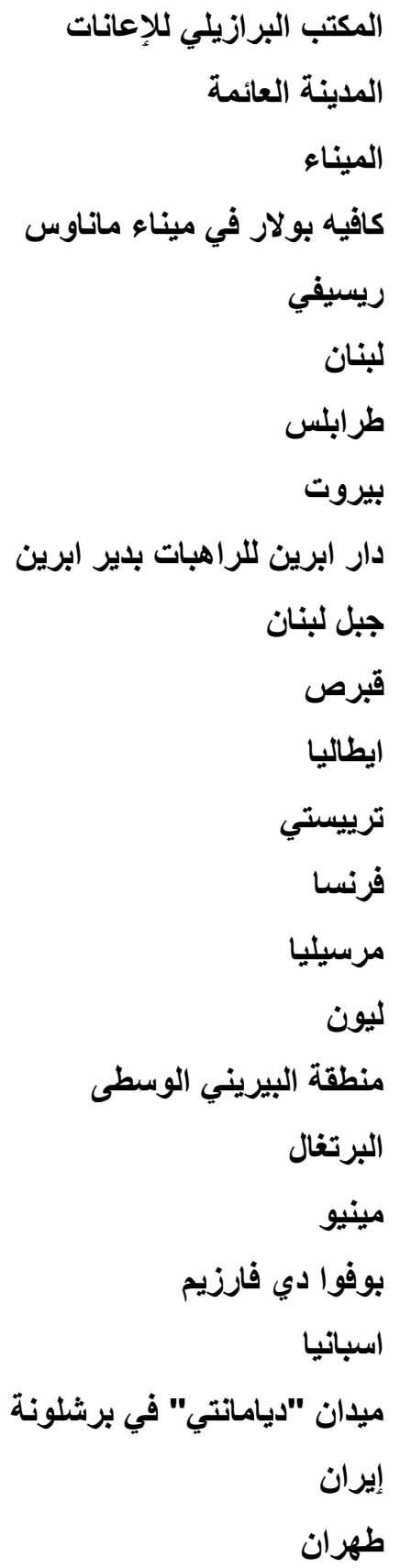




\section{Anexo 4: Análise de fenômenos de tradução}

\begin{tabular}{|c|c|c|c|c|}
\hline Cap & Unidades do Texto Fonte & $\mathrm{TF}$ & Unidades do Texto Traduzido & $\begin{array}{l}\text { Intervenções na interpretação e } \\
\text { na recriação no processo da } \\
\text { tradução }\end{array}$ \\
\hline $1^{\circ}$ & "Para Rita" & 7 & "لهيتا أو لريتا" & $\begin{array}{l}\text { Tradução prefixada de nome } \\
\text { próprio /rita/ em vez de /hita/ } \\
\text { Ao início, enfrentamos duas } \\
\text { traduções possíveis: A primeira } \\
\text { /hita/ representava resistência ao } \\
\text { imperialismo linguístico do } \\
\text { inglês e do francês. } \\
\text { A segunda, a qual aderimos } \\
\text { finalmente na revisão, é a } \\
\text { tradução prefixada de /Rita/ em } \\
\text { árabe para que o leitor possa } \\
\text { imaginar a imagem do nome. } \\
\text { Franco Aixellá. (2000). }\end{array}$ \\
\hline 1 & "Criança" & 9 & 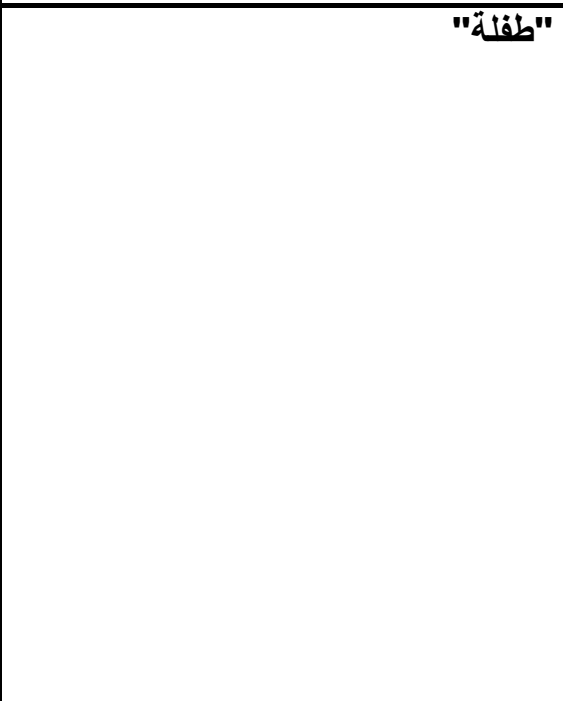 & $\begin{array}{l}\text { Específicação do gênero } \\
\text { "Criança" é uma palavra } \\
\text { feminina em português que se } \\
\text { refere aos dois gêneros. Pode ser } \\
\text { um bebê ou uma criança. Em } \\
\text { árabe, há palavras diferentes para } \\
\text { o masculino "menino" e o } \\
\text { feminino "menina". Definição do } \\
\text { sentido contextual mais geral } \\
\text { adequado da palavra "criança". }\end{array}$ \\
\hline
\end{tabular}




\begin{tabular}{|c|c|c|c|c|}
\hline $1^{\circ}$ & $\begin{array}{l}\text { "As duas figuras estavam } \\
\text { inertes diante de mim,..." }\end{array}$ & 9 & "الثخصيتّان كاتتا ساكنتين أمامي" & $\begin{array}{l}\text { Especificação } \text { sintáctica } \\
\text { tradução do dual "as duas } \\
\text { figuras" para a língua árabe que } \\
\text { se caracteriza por marcas do dual } \\
\text { na conjugação verbal e no } \\
\text { adjetivo do dual, marcas ausentes } \\
\text { em português. }\end{array}$ \\
\hline 1 & $\begin{array}{l}\text { "vi o vulto de uma mulher } \\
\text { e o de uma criança" }\end{array}$ & 9 & |"رأيت شبحي أمرأة وطفلة" & $\begin{array}{l}\text { Especificação sintáctica na } \\
\text { tradução da polissemia da palavra } \\
\text { "vulto" (Assombração, fantasma, } \\
\text { sombra, passo rápido de uma } \\
\text { pessoa). } \\
\text { Também a maneira de não repetir } \\
\text { vulto em português foi por meio } \\
\text { do artigo "o", enquanto em árabe } \\
\text { se coloca marca de dual e se } \\
\text { coloca justapostos os dois } \\
\text { substantivos: "dois vultos de } \\
\text { mulher e de criança.". }\end{array}$ \\
\hline $1^{\circ}$ & "Mangueira" & 9 & | "شجر المانجو" & $\begin{array}{l}\text { Especificação semântica do } \\
\text { sentido adequado da palavra } \\
\text { polissêmica "mangueira" para } \\
\text { manter o sentido de "árvore de } \\
\text { manga" e excluir o sentido de } \\
\text { "mangueira de água". }\end{array}$ \\
\hline
\end{tabular}




\begin{tabular}{|c|c|c|c|c|}
\hline 1 & $\begin{array}{l}\text { "A ave silenciou.Nos } \\
\text { meses de negociação com } \\
\text { o marselhês, Hindie levou } \\
\text { o papagaio de volta à sua } \\
\text { casa, empenhou-se } \\
\text { arduamente para que ele } \\
\text { recuperasse a voz e logrou } \\
\text { ensinar-lhe algumas frases } \\
\text { em francês.O marselhês } \\
\text { ficou tão impressionado } \\
\text { com a desenvoltura } \\
\text { fonética da ave que, } \\
\text { temendo a sua fuga, } \\
\text { aparou-lhe as penas, } \\
\text { construiu-lhe uma gaiola } \\
\text { de bambu e contrariando } \\
\text { o sexo do animal, } \\
\text { rebatizou-a com o nome } \\
\text { de Strabon" a }\end{array}$ & 27 & 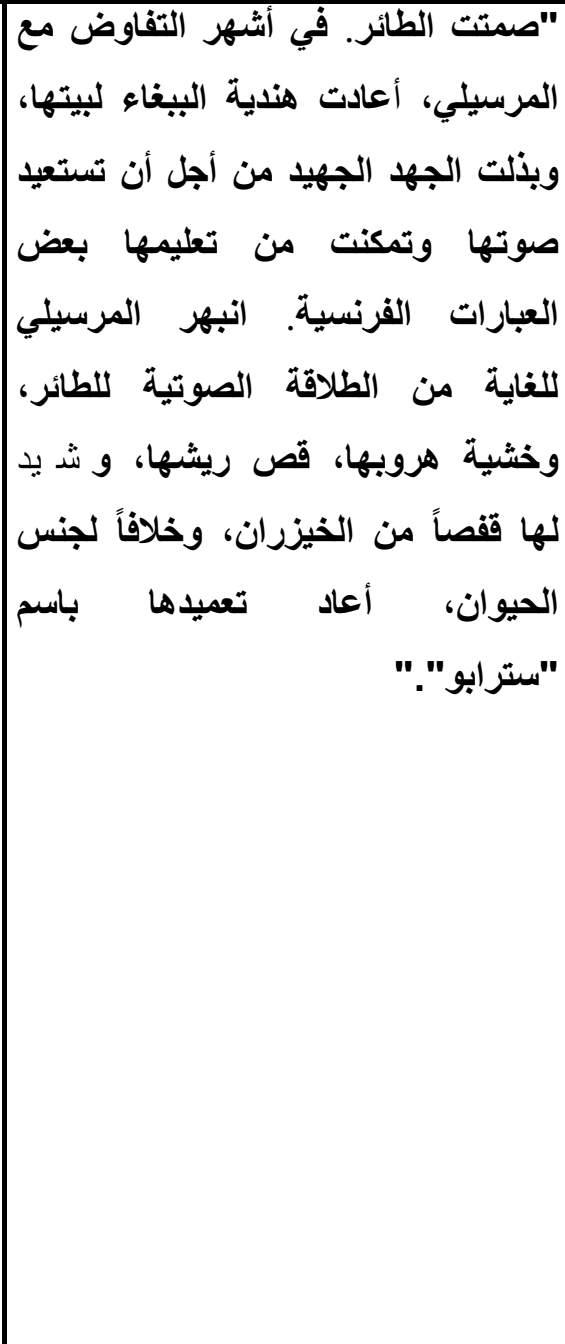 & $\begin{array}{l}\text { Especificação da marcação do } \\
\text { gênero feminino nos substantivos } \\
\text { "a casa, a voz e as penas", no } \\
\text { pronome "sua fuga" e no verbo } \\
\text { "ensinar-lhe" em árabe para } \\
\text { referir-se à feminidade da palavra } \\
\text { ave em português, sendo a } \\
\text { mesma masculina em árabe. }\end{array}$ \\
\hline
\end{tabular}




\begin{tabular}{|c|c|c|c|c|}
\hline 1 & $\begin{array}{l}\text { "O vício dos levantinos } \\
\text { mais velhos" }\end{array}$ & 29 & "عادة الأكبرسناً من المشـارقة" & $\begin{array}{l}\text { Independentemente } \\
\text { contexto, houve } \\
\text { semântica do } \\
\text { pentido } \\
\text { polissêmico } \\
\text { "levantino" da } \\
\text { pessoas da } \\
\text { Cham) ou pode significar o este } \\
\text { do Mediterrâneo. Também a } \\
\text { palavra "vício" vira-se "costume" } \\
\text { em árabe. }\end{array}$ \\
\hline 2 & $\begin{array}{l}\text { “...no punho da mão } \\
\text { esquerda enroscava-se a } \\
\text { alça de uma caixa que ele } \\
\text { segurava com a firmeza e } \\
\text { a avidez de um gavião } \\
\text { que agarra uma presa.” }\end{array}$ & 42 & 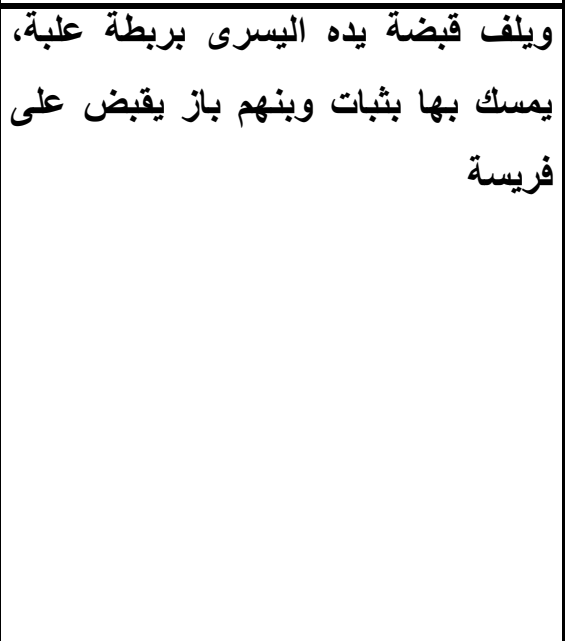 & 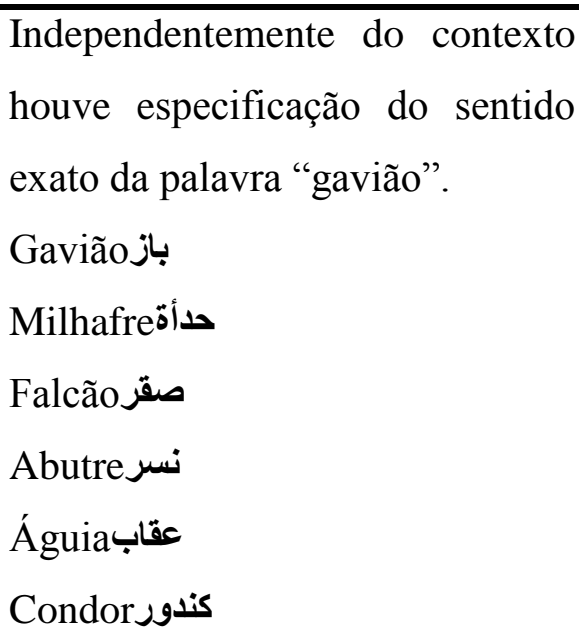 \\
\hline
\end{tabular}




\begin{tabular}{|c|c|c|c|c|}
\hline 4 & "Um tio meu, Hanna" & 71 & "أحد أعمامي حنا" & $\begin{array}{l}\text { Específicação semântica na } \\
\text { língua árabe que tem que definir } \\
\text { se é o tio paterno ou materno... } \\
\text { Mais adiante o escritor define que } \\
\text { Hanna é o tio do pai do } \\
\text { narrador...Um dos meus tios (do } \\
\text { meu pai) Hanna }\end{array}$ \\
\hline 4 & $\begin{array}{l}\text { "O mais imaginoso entre } \\
\text { os irmãos do meu pai;..." }\end{array}$ & 73 & "الأوفر خيالاً من بين أعمامي" & $\begin{array}{l}\text { Especificacão semântica dos } \\
\text { irmãos do meu pai, tios do lado } \\
\text { do meu pai, e se diz em árabe em } \\
\text { uma palavra só "أعمامي". }\end{array}$ \\
\hline
\end{tabular}




\begin{tabular}{|c|c|c|c|c|}
\hline 4 & $\begin{array}{l}\text { "Nas cidades litorâneas do } \\
\text { sul" }\end{array}$ & 71 & "في المدن الساحلية جنوب لبنان" & $\begin{array}{l}\text { A partir de várias leituras, } \\
\text { percebemos o contexto narrativo } \\
\text { e conseguimos especificação da } \\
\text { referência do sul do Líbano. }\end{array}$ \\
\hline 1 & $\begin{array}{l}\text { "- Posso passar o resto da } \\
\text { minha vida falando do } \\
\text { passado- disse, com voz } \\
\text { mais descansada." }\end{array}$ & 31 & 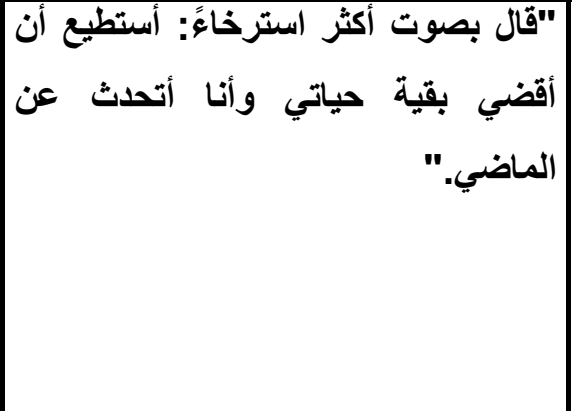 & $\begin{array}{l}\text { Desambiguação: A partir de } \\
\text { várias leituras da situação } \\
\text { narrativa conseguimos a } \\
\text { decifração da ambiguidade do } \\
\text { sujeito do verbo "Disse" (eu ou } \\
\text { ele) }\end{array}$ \\
\hline
\end{tabular}




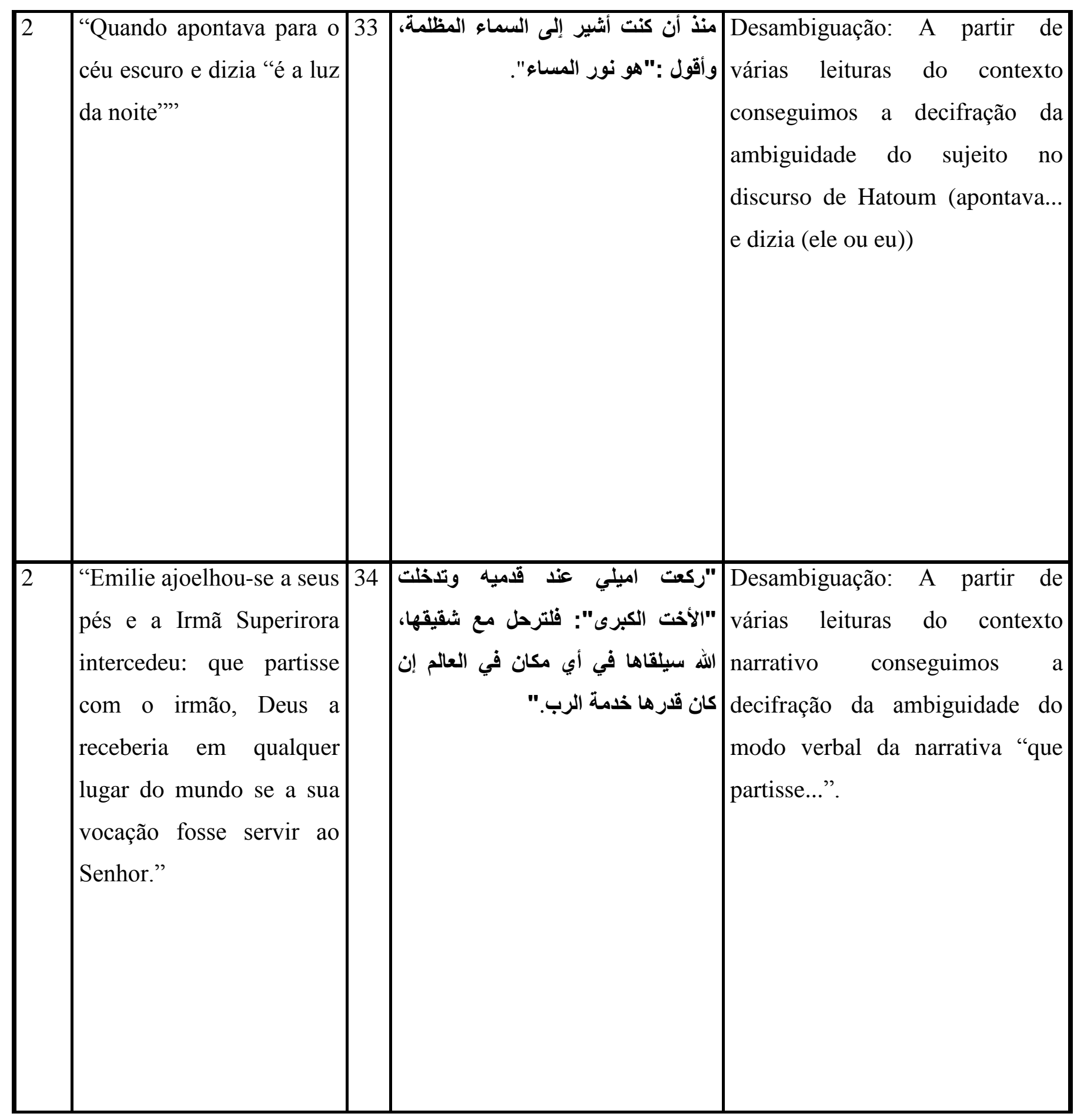




\begin{tabular}{|c|c|c|c|c|}
\hline 2 & $\begin{array}{l}\text { "Emilie teria ficado } \\
\text { boquiaberta e extática ao } \\
\text { escutar o som das doze } \\
\text { pancadas..." }\end{array}$ & 34 & 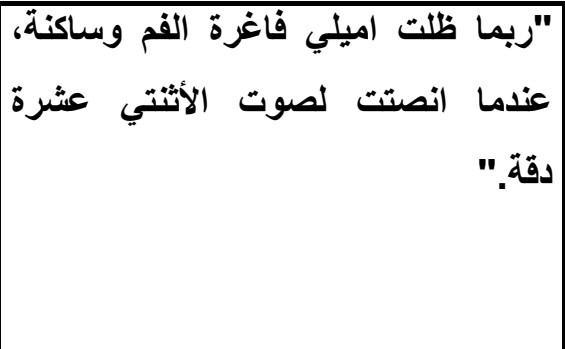 & $\begin{array}{l}\text { A partir de } \\
\text { percebemos } \\
\text { o }\end{array}$ \\
\hline $1^{\circ}$ & $\begin{array}{l}\text { "Ingressado numa espécie } \\
\text { de gruta vegetal, entre o } \\
\text { globo de luz e o } \\
\text { caramanchão que dá } \\
\text { acesso aos fundos da } \\
\text { casa... continuou imóvel, } \\
\text { com o olhar perdido na } \\
\text { escuridão da gruta..." }\end{array}$ & 9 & 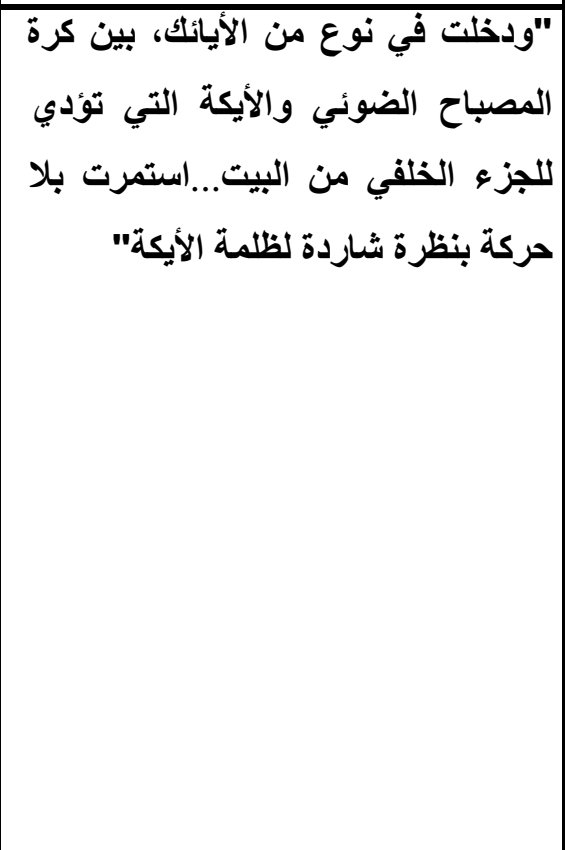 & $\begin{array}{l}\text { Visualizacão da imagem de } \\
\text { "gruta" na passagem: } \\
\text { "Ingressado numa espécie de } \\
\text { gruta vegetal, entre o globo de } \\
\text { luz e o caramanchão que dá } \\
\text { acesso aos fundos da casa... } \\
\text { continuou imóvel, com o olhar } \\
\text { perdido na escuridão da gruta..." } \\
\text { A imagem tem muita importância } \\
\text { para poder traduzir palavras que } \\
\text { não constam em dicionários } \\
\text { bilíngues. }\end{array}$ \\
\hline
\end{tabular}




\begin{tabular}{|c|c|c|c|c|}
\hline 1 & $\begin{array}{l}\text { "Jorros d'água da boca de } \\
\text { pedra dos anjos..." }\end{array}$ & 24 & 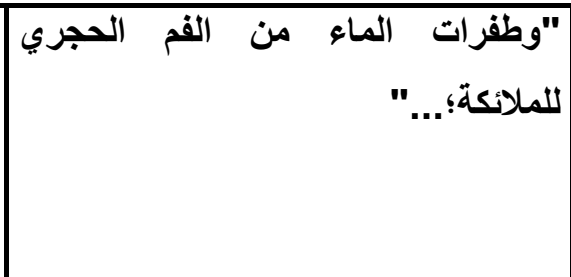 & $\begin{array}{l}\text { Visualização das imagens } \\
\text { narradas da passagem "Jorros d } \\
\text { água da boca de pedra dos anjos" } \\
\text { para poder traduzir. }\end{array}$ \\
\hline 1 & $\begin{array}{l}\text { "sobrado" } \\
\text { "Casarão" }\end{array}$ & 29 & "'فيلا" & $\begin{array}{l}\text { Visualização do sentido de } \\
\text { "casarão", e buscar o equivalente } \\
\text { da palavra que dista de palavras } \\
\text { do mesmo campo semântico } \\
\text { repetido no texto de Hatoum } \\
\text { como sobrado, casa, casarão e } \\
\text { palafita. } \\
\text { Tradicionalmente, a imigração } \\
\text { libanesa no Brasil costumava } \\
\text { morar em sobrados. É curioso } \\
\text { que no Al Andaluz (711-1492) no } \\
\text { sul da Península Ibérica (Espanha } \\
\text { e Portugal) a casa árabe } \\
\text { costumava ser um sobrado: No } \\
\text { segundo andar era o lar, no } \\
\text { primeiro andar era a loja e em } \\
\text { frente ao sobrado havia um pátio } \\
\text { que tinha jardim e fonte de água. }\end{array}$ \\
\hline $1^{\circ}$ & $\begin{array}{l}\text { "...consolos recapeados de } \\
\text { ônix..." }\end{array}$ & 10 & "طاولة" كونسولا "مطعمة بالعقيق" & $\begin{array}{l}\text { Tradução de "consolo", uma } \\
\text { referência cultural colonial } \\
\text { francesa deslocada da metrópole } \\
\text { libanesa para a metrópole } \\
\text { amazonense. }\end{array}$ \\
\hline
\end{tabular}




\begin{tabular}{|c|c|c|c|c|}
\hline $1^{\circ}$ & "Natal" & 13 & "عيد الميلاد" & 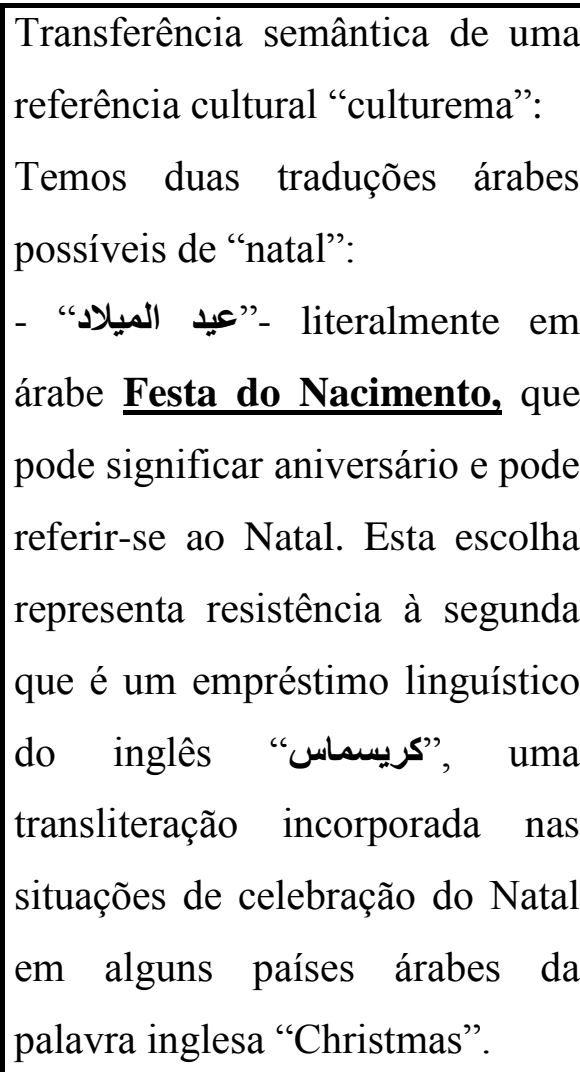 \\
\hline $1^{\circ}$ & "O rabo dos macacos" & 13 & "ذيول القرود" & $\begin{array}{l}\text { Mudança estilística por } \\
\text { divergência entre o sistema } \\
\text { linguístico português e o árabe. } \\
\text { Em português, o genitivo singular } \\
\text { justaposto ao plural: "O rabo dos } \\
\text { macacos". } \\
\text { Em árabe, o genitivo plural } \\
\text { justaposto ao plural: "Os rabos } \\
\text { dos macacos.". }\end{array}$ \\
\hline
\end{tabular}




\begin{tabular}{|c|c|c|c|c|}
\hline 1 & "Sereno" & 15 & "رطوبة الهواء" & $\begin{array}{l}\text { Preservaç̃o da referência ao } \\
\text { ambiente natural de Manaus, } \\
\text { onde o ar do sereno é úmido pelo } \\
\text { calor e não tão frio como em } \\
\text { outras regiões. }\end{array}$ \\
\hline 1 & $\begin{array}{l}\text { "...nunca se contrariou } \\
\text { com nossa presença na } \\
\text { casa..." }\end{array}$ & 20 & "لم ينزعج قط وجودنا في البيت..." & $\begin{array}{l}\text { Preservação do } \text { sentido } \\
\text { semântico da forma pronominal } \\
\text { "Contrariar-se com = embaraçar- } \\
\text { se com ou aborrecer-se com", a } \\
\text { diferença do sentido da forma } \\
\text { simples "contrariar = opor-se a". }\end{array}$ \\
\hline 1 & $\begin{array}{l}\text { "Praçã do Diamante" } \\
\text { "Nossa Senhora dos } \\
\text { Remédios" }\end{array}$ & $\begin{array}{l}12 \\
28\end{array}$ & ميدان "ديامانتي" & $\begin{array}{l}\text { Preservação das formas } \\
\text { transliteradas dos nomes próprios } \\
\text { na tradução de "Praça do } \\
\text { Diamante" e "A Igreja da Nossa } \\
\text { Senhora dos Remédios" }\end{array}$ \\
\hline
\end{tabular}




\begin{tabular}{|c|c|c|c|c|}
\hline 3 & $\begin{array}{l}\text { "...falava } \\
\text { algaravia..." }\end{array}$ & 62 & "كان يتكلم لغة غريبة" & $\begin{array}{l}\text { Preservação da tendência ao uso } \\
\text { de palavras de origen árabe. } \\
\text { "Algaravia" que se refere em } \\
\text { português à "estranheza", } \\
\text { referência metafórica a qualquer } \\
\text { língua estranha. A língua árabe o } \\
\text { para Dorner. "Algaravia" é uma } \\
\text { palavra de origem árabe que vem } \\
\text { da região "algarve" no Portugal } \\
\text { que significa em árabe "oeste" de } \\
\text { Analuzia no sul Portugal que foi } \\
\text { governado pelos árabes desde } \\
715 \text { até } 1492 \text {. }\end{array}$ \\
\hline 1 & $\begin{array}{l}\text { Na mesa, à hora das } \\
\text { refeições, tu e Soraya } \\
\text { eram servidos pelas mãos } \\
\text { de Emilie, sempre em } \\
\text { movimento: descascando } \\
\text { frutas, separando os } \\
\text { alimentos para cada um } \\
\text { de vocês, mas tu já podias } \\
\text { negar ou aceitar a comida } \\
\text { com poucas palavras, } \\
\text { como monossílabos, } \\
\text { enquanto } \\
\text { resignava-se a afastar o } \\
\text { prato, negacear com a } \\
\text { cabeça ou curvá-la em } \\
\text { direção ao prato, às vezes } \\
\text { olhando para ti, para tua } \\
\text { boca, tal vez pensando: }\end{array}$ & $\begin{array}{l}16 \\
- \\
17\end{array}$ & 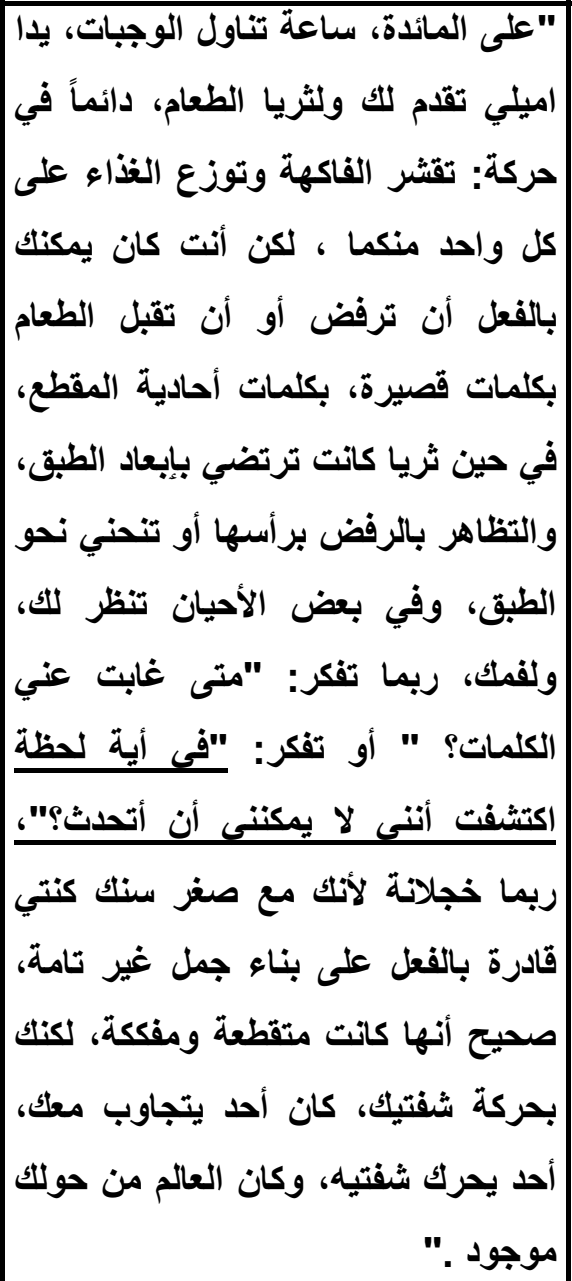 & $\begin{array}{l}\text { Identificação de uma voz no } \\
\text { monólogo narrativo (quem fala } \\
\text { e como fala) e distingui-la das } \\
\text { outras vozes por meio das aspas } \\
\text { do discurso direto e também das } \\
\text { implicâncias da situação surda- } \\
\text { muda da personagem. Assim que } \\
\text { o sujeito da frase "não podia } \\
\text { falar" refere-se ao pronome "eu" } \\
\text { e não ao "ele/ela". } \\
\text { Kohn, Sílvia Adela. Como } \\
\text { escrever diálogos- A arte de } \\
\text { desenvolvoer o diálogo no } \\
\text { romance e no conto, Gutenberg, } \\
\text { Belo Horizonte. 2011. }\end{array}$ \\
\hline
\end{tabular}




\begin{tabular}{|c|c|c|c|c|}
\hline & $\begin{array}{l}\text { "Quand me faltou a } \\
\text { palavra?", ou pensando: } \\
\text { "Em que momento } \\
\text { descobri que não podia } \\
\text { falar...", tal vez vexada } \\
\text { porque tu, com a tua } \\
\text { pouca idade, já eras capaz } \\
\text { de construir frases mal } \\
\text { acabadas, fracionadas, } \\
\text { desconexas, é verdade, } \\
\text { mas com um movimento } \\
\text { dos teus lábios, alguém } \\
\text { reagia, alguém movia os } \\
\text { lábios, o mundo ao teu } \\
\text { redor existia." }\end{array}$ & & & \\
\hline 1 & $\begin{array}{l}\text { "Vestido de malha....touca } \\
\text { de renda preta..." }\end{array}$ & 20 & "ثوب من نسيج... قبعة دانتيل أسود" & 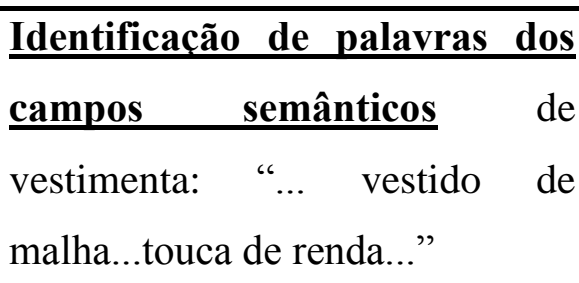 \\
\hline 1 & $\begin{array}{l}\text { "...tudo poderia ir por } \\
\text { águas abaixo..." }\end{array}$ & 25 & " قد تخسر كل شيع" & $\begin{array}{l}\text { Simplificação } \text { da } \\
\text { (expressão metafórica comum) } \\
\text { “... tudo poderia ir por águas } \\
\text { abaixo...” para ser “... poderia } \\
\text { perder tudo...” }\end{array}$ \\
\hline
\end{tabular}




\begin{tabular}{|c|c|c|c|c|}
\hline 1 & $\begin{array}{l}\text { "Nosso avô estranhou que } \\
\text { Emilie se empenhasse } \\
\text { tanto na aquisição do } \\
\text { relógio..." }\end{array}$ & 28 & 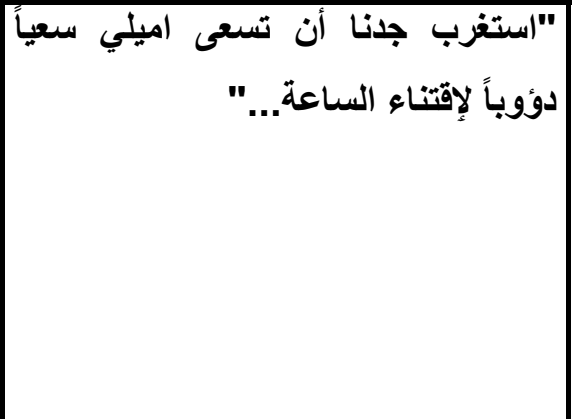 & $\begin{array}{l}\text { Inversão sujeito e verbo na } \\
\text { tradução do português para o } \\
\text { árabe para ficar em árabe como } \\
\text { "Estranhou nosso avô que se } \\
\text { empenhasse Emilie tanto na } \\
\text { aquisição do relógio". }\end{array}$ \\
\hline 2 & $\begin{array}{l}\text { "caboclos recém- } \\
\text { chegados do interior" }\end{array}$ & 35 & |أعالي النهر" "الكابوكلوالذين وصلوا حليثاً من أقاليم & $\begin{array}{l}\text { Explicacão numa nota do } \\
\text { culturema (referente cultural) } \\
\text { “caboclo" que é a mistura de } \\
\text { indígena com europeu. } \\
\text { Explicitacão pragmática do } \\
\underline{\text { sentido de "interior" aqui que }} \\
\text { refere às partes altas do Rio } \\
\text { Amazonas. }\end{array}$ \\
\hline 2 & $\begin{array}{l}\text { "“"Tão cedo não morres", } \\
\text { exclamou Arminda com } \\
\text { um sotaque perfeito do } \\
\text { Minho" }\end{array}$ & 42 & | وهلفت مينيو:"أرميندا بلكنة مطابقة تماماً للكنة & $\begin{array}{l}\text { Explicitaç̃o pragmática do } \\
\text { sentido da expressão "tão cedo } \\
\text { não morres" com uma } \\
\text { equivalente pragmática em árabe } \\
\text { "longa vida para você, estávamos } \\
\text { falando de você agora mesmo." }\end{array}$ \\
\hline 2 & "bem ou mal" & 53 & "في الحلوة والمرة" & $\begin{array}{l}\text { Substituição da expressão por } \\
\text { uma equivalente árabe } \\
\text { pragmática que dá o sentido de } \\
\text { "bem ou mal”. Em árabe vai ser } \\
\text { "na doçura e na amargura". }\end{array}$ \\
\hline
\end{tabular}




\begin{tabular}{|c|c|c|c|c|}
\hline 2 & "Indumentária luxuriante" & 54 & |"ملابس مبهرة" & 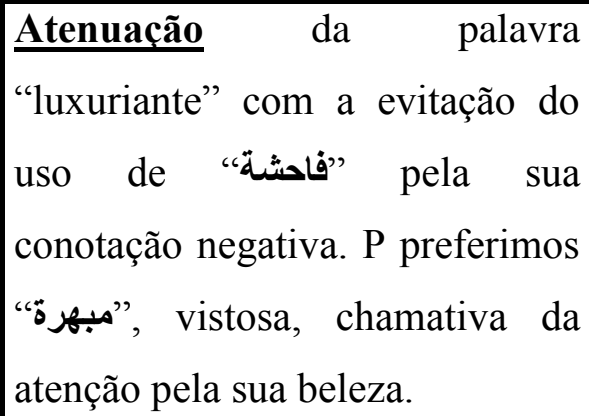 \\
\hline 3 & "Igarapé de Educandos" & 62 & "مجرى "إدوكندوس" المائي" & $\begin{array}{l}\text { Explicitação do sentido cultural } \\
\text { da palavra "igarapé" com a } \\
\text { adição em árabe da expressão } \\
\text { "corrente aquática do percurso" } \\
\text { de Educandos. O escritor usou a } \\
\text { palavra "igarapé" que é de } \\
\text { origem tupi e significa percurso } \\
\text { da barca ou rio pequeno. } \\
\text { Traduzi no árabe como seu } \\
\text { sentido no tupí "percurso do } \\
\text { água". } \\
\text { Na tradução árabe de Dois } \\
\text { Irmãos, a professora Safá } \\
\text { traduziu "igarapé" como "canal”. } \\
\text { O problema é que "canal" é uma } \\
\text { via artificial e isso é diferente do } \\
\text { igarapé. }\end{array}$ \\
\hline
\end{tabular}




\begin{tabular}{|c|c|c|c|c|}
\hline 3 & $\begin{array}{l}\text { "Até Emilie e o teu tio } \\
\text { Emílio notaram o meu } \\
\text { assombro. Senti no rosto } \\
\text { um vazio, como se } \\
\text { tivessem vendado meus } \\
\text { olhos..." }\end{array}$ & 64 & 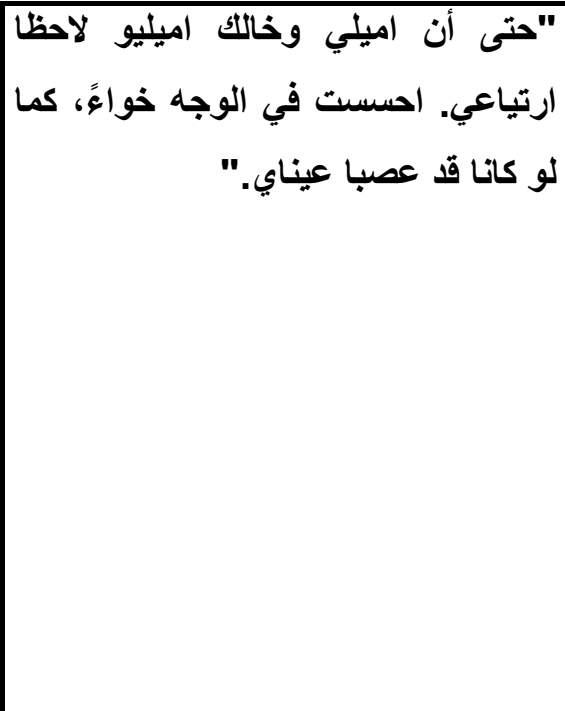 & $\begin{array}{l}\text { Codificação de diferencias } \\
\text { linguísticas. O tradutor tem que } \\
\text { prestar atenção à conjugação } \\
\text { verbal árabe com o sujeito dual } \\
\text { em árabe. Porque em português } \\
\text { não tem marca da dualidade do } \\
\text { sujeito "Emilie } \boldsymbol{e} \text { o teu tio } \\
\text { Emílio" na conjugação verbal } \\
\text { dos verbos "notaram" } \\
\text { "tivessem vendado". }\end{array}$ \\
\hline 3 & $\begin{array}{l}\text { ", enquanto as pessoas } \\
\text { olhavam perpelexas para } \\
\text { os dois corpos que faziam } \\
\text { esquecer o afogado, a } \\
\text { busca, o motivo de } \\
\text { estarmos ali" }\end{array}$ & 66 & 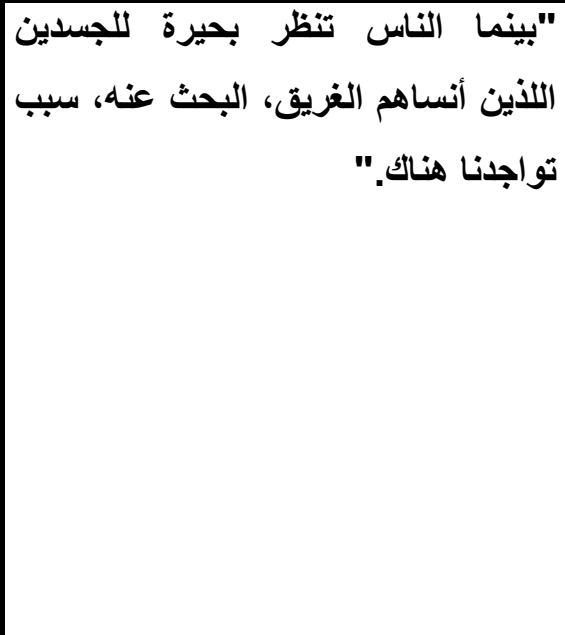 & $\begin{array}{l}\text { Adicão de pronome pelas } \\
\text { exigências linguísticas da língua } \\
\text { árabe, que reivindica a existência } \\
\text { de complementos pronominais ao } \\
\text { final de verbos transitivos. } \\
\mathrm{Na} \text { tradução, "faziam esquecer" } \\
\text { fica como "fazia esquecer -lhe- } \\
\text { se" e "a busca" fica como "a } \\
\text { busca dele". }\end{array}$ \\
\hline
\end{tabular}




\section{Anexo 5: Narrativas que jogam com o imaginário da imigração árabe no Brasil}

ABRÃO, Gilberto, Mohamed, O Latoeiro. São Paulo: Primavera Editorial, 2009.

ABRÃO, Gilberto. O Muçulmano e a judia. São Paulo: Companhia Editora Nacional, 2011.

AMADO, Jorge. A descoberta das Américas pelos turcos. Rio de Janeiro: Record, 1994.

CHEUÍCHE, Alcy. Jabal Lubnan, As Aventuras de um Mascate Libanês. Porto Alegre: Unisul, 2004.

HATOUM, Milton. Relato de um Certo Oriente. São Paulo: Cia. das Letras, 1990.

HATOUM, Milton. Dois Irmãos. São Paulo: Cia. das Letras, 2000.

HATOUM, Milton. Cidade ilhada. São Paulo: Cia. das Letras, 2009.

LEVY, Tatiana Salem (Org). Os primos. Rio de Janeiro: Record, 2010.

MIGUEL, Selim. Nur na escuridão. Rio de Janeiro: Record, 2008.

MIRANDA, Ana Amrik. São Paulo: Cia das Letras, 1997.

NASSAR, Raduan. Lavoura Arcaica. 3. Ed. São Paulo: Companhia das Letras, 1989. 